CESAR MECCHI MORALES

\title{
ORIGINALISMO E INTERPRETAÇÃO CONSTITUCIONAL
}

Tese apresentada como requisito parcial para obtenção do título de doutor em Direito do Estado (Direito Constitucional).

Orientador: Professor Associado ALEXANDRE DE MORAES

UNIVERSIDADE DE SÃO PAULO

FACULDADE DE DIREITO

SÃO PAULO

2011 
BANCA EXAMINADORA 


\section{ÍNDICE}

INTRODUÇÃO - 1

\section{CAP. 1 - ALGUMAS REFLEXÕES SOBRE A INTERPRETAÇÃO DAS LEIS E DA CONSTITUIÇÃO}

1.1. A interpretação e seus limites, 6

1.2 A intepretação no direito, 7

1.3 Hermenêutica e interpretação, 9

1.4 Métodos ou elementos clássicos de interpretação, 10

1.5 Objetividade e subjetividade da interpretação, 12

1.6 Conceito de interpretação constitucional, 15

1.7 Especificidade da interpretação constitucional, 16

1.8 Princípios e métodos de interpretação constitucional, 17

1.9 A complementaridade dos métodos, 21

1.10 A importância da "vontade do constituinte", 23

1.11 Os excessos da interpretação constitucional: o ativismo judicial, 25

\section{CAP. 2 - O MOVIMENTO ORIGINALISTA NOS ESTADOS UNIDOS}

2.1 Conceito e contextualização do originalismo, 31

2.2 O originalismo como reação ao ativismo, 32

2.3 Evolução do originalismo, 35

2.4 A indicação de Robert Bork para a Suprema Corte, 38

2.5 Principais críticas ao originalismo, 40

\section{CAP. 3 - INTERPRETAÇÃO ORIGINALISTA EM OUTROS PAÍSES}

3.1 Considerações iniciais, 47

3.2 Austrália, 49

3.3 Japão, 53

3.4 Itália, 63

3.5 Espanha, 67

3.6 Portugal, 71 


\subsection{Argentina}

3.7.1 A coexistência de múltiplos critérios, 81

3.7.2 A interpretação voluntarista, 82

3.7.3 Vontade do legislador e interpretação constitucional, 84

3.7.4 Abordagem originalista na doutrina, 88

3.7.5 Tentativas de síntese, 92

3.8 Chile

3.8.1 As atas da Comissão Ortúzar, 96

3.8.2 A interpretação originalista da Constituição, 97

3.8.3 Interpretação originalista no Tribunal Constitucional, 100

3.9 Resumo do capítulo, 108

\section{CAP. 4 - ENFOQUE ORIGINALISTA EM QUESTÕES CONSTITUCIONAIS BRASILEIRAS (período anterior a 1988)}

4.1 Explicação prévia, 110

4.2 Constituição de 1824, 112

4.3 Constituição de 1891

4.3.1 A relevância dos anais da Assembléia, 119

4.3.2 Abordagem originalista em Carlos Maximiliano, 121

4.3.3 Abordagem originalista em João Barbalho, 125

4.3.4 Abordagem originalista em Rui Barbosa, 128

4.3.5 A questão do sufrágio feminino, 135

4.4 Constituição de 1934, 140

4.5 Constituição de 1946, 142

\section{CAP. 5 - ENFOQUE ORIGINALISTA EM QUESTÕES CONSTITUCIONAIS BRASILEIRAS (a partir de 1988)}

5.1 Considerações iniciais, 149

5.2 Tabelamento dos juros, 151

5.3 A revisão constitucional e o plebiscito (arts. $2^{\circ}$ e $3^{\circ}$ do ADCT)

5.3.1 O surgimento da controvérsia, 155

5.3.2 A Decisão do Supremo Tribunal Federal, 157

5.3.4 Análise originalista da questão, 158

5.4 A questão dos efeitos do Mandado de Injunção

5.4.1 Colocação da controvérsia, 164

5.4.2 A intenção do constituinte como argumento dos concretistas, 166

5.4.3 O argumento histórico na defesa da posição não concretista, 168 
5.5. Conceito de veículo automotor para fins tributários, 176

5.6 Conceito constitucional de racismo, 179

5.7. Perda de mandato por infidelidade partidária, 189

5.7.1 Pressuposto da análise originalista: o histórico normativo, 189

5.7.2 Posição da doutrina até 2007, 196

5.7.3 A jurisprudência do STF e do TSE de 1988 a 2007, 201

5.7.4 A alteração da Constituição pela via jurisprudencial, 206

5.7.5 Posição da doutrina após a mudança jurisprudencial, 208

5.7.6 Uma crítica originalista, 211

5.8 Reinterpretação da Lei de Anistia, 220

5.8.1 O sentido original da norma, 231

5.8.2 A constitucionalização da anista, 225

5.8.3 O surgimento da controvérsia, 227

5.8.4 A questão chega ao STF, 230

5.8.5 Os pareceres da AGU e da PGR, 231

5.8.6 O julgamento, 235

5.8.7 O significado da decisão, 241

5.9 Uma questão pendente: o conceito constitucional de quilombo

5.9.1 Colocação do problema, 242

5.9.2 O entendimento original do art. 68 do ADCT, 243

5.9.3 Histórico da elaboração do dispositivo constitucional, 247

5.9.4 A "releitura" ou "ressemantização" do conceito de quilombo, 250

5.9.5 Análise originalista, 255

5.10 Balanço e perspectivas, 256

CONCLUSÕES 258

BIBLIOGRAFIA 262 
Observações:

1. Todas as citações de textos consultados em línguas estrangeiras (inglês, italiano e espanhol) foram traduzidas. Indicamos as expressões originais apenas quando estritamente necessário, ou para melhor esclarecer o sentido do texto.

2. Seguindo recomendações da ABNT, as citações de textos com até três linhas foram incorporadas aos parágrafos normais, destacadas em itálico e entre aspas.

3. Também seguindo as normas da ABNT, as citações de textos com mais de três linhas foi feita em parágrafo à parte, com recuo e em letra menor, mantido o mesmo espaçamento. Embora neste caso não sejam exigidas aspas, consideramos mais adequado utilizá-las.

4. Verificou-se em janeiro de 2011 o acesso a todas as páginas da internet citadas na bibliografia e notas de rodapé. 


\section{RESUMO}

O presente trabalho tem por objeto o estudo do originalismo, em várias de suas versões, no contexto da interpretação constitucional. No primeiro capítulo são tecidas considerações gerais sobre a interpretação jurídica, bem como princípios e métodos específicos da interpretação constitucional, com destaque para o elemento histórico. No segundo capítulo, são analisadas as razões que ensejaram o surgimento e o desenvolvimento do originalismo nos Estados Unidos, onde é considerado um dos mais importantes meios de auto-contenção judicial. A seguir, é examinada a presença de abordagens similares em outros países. Nos capítulos finais, é investigada a utilização de argumentos originalistas em questões constitucionais brasileiras. A tese procura ressaltar a importância da técnica originalista e sua utilidade como critério complementar a outros elementos de interpretação, bem como sua efetividade como meio de evitar os excessos do ativismo judicial.

Palavras-chave:

originalismo

interpretação constitucional 


\begin{abstract}
The purpose of this paper is the study of originalism in several of its versions within the context of constitutional interpretation. The first chapter contains general considerations regarding legal interpretation as well as principles and methods specific to constitutional interpretation, with emphasis on the historic element. The second chapter analyzes the reasons that brought about the appearance/emergence and development of originalism in the United States, where it is regarded as one of the leading means of judicial selfrestraint. Next, the existence of similar approaches in other countries will be examined and the final chapters will investigate the use of originalistic arguments in Brazilian constitutional questions. This thesis seeks to highlight the importance of the originalistic technique and its use as a criterion complementary to other elements of interpretation, as well as its effectiveness as a way to avoid the excesses of judicial activism.
\end{abstract}

\title{
Key words
}

Originalism

Constitutional Interpretation 


\section{RIASSUNTO}

Questa tesi si propone lo studio dell'originalism nelle sue varie versioni, nel contesto dell'interpretazione costituzionale. Nel primo capitolo si trovano alcune considerazioni generali sulla interpretazione giuridica, nonché specifici principi e metodi di interpretazione costituzionale, in particolare l'elemento storico. Il secondo capitolo analizza le ragioni che hanno causato la nascita e lo sviluppo dell' originalismo negli Stati Uniti, dove è considerato uno dei più importanti mezzi di autocontrollo giudiziario. Di seguito, si esamina la presenza di approcci simili in altri paesi. Nei capitoli finali, abbiamo studiato l'uso di argomento dell'original intent su questioni costituzionali in Brasile. La tesi cerca di evidenziare l'importanza della tecnica originalista e la sua utilità come criterio per completare gli altri elementi di interpretazione, e la sua efficacia come mezzo per evitare gli eccessi dell'attivismo giudiziario.

Parole chiavi

Originalism

Interpretazione costituzionale 


\section{INTRODUÇÃO}

A aplicação de qualquer norma jurídica demanda, antes de mais nada, sua correta interpretação. O antigo brocardo "in claris cessat interpretatio" somente será verdadeiro se compreendido (e aqui já estamos interpretando) como um conselho prático - bem ao estilo dos romanos, por sinal. Se tomado em termos de lógica estrita, exprimirá uma contradição, pois para afirmar que determinado enunciado é claro precisaremos, em primeiro lugar, interpretá-lo.

Manuel Domingues de Andrade chega a afirmar que "nenhum problema tem mais interesse" para o direito do que a interpretação das leis, que se encontra "na base de todos os outros". Por isso mesmo, afirma "a imperiosa necessidade" de uma doutrina ou teoria, com "idéias e critérios gerais" que possam orientar o jurista na atividade interpretativa, com vistas à aplicação correta das leis ${ }^{1}$.

O filósofo Hans-Georg Gadamer salienta, no clássico Verdade e Método, que

“... a minuciosa ordenação da vida através das regras do
direito e dos costumes é incompleta, necessitando de uma
complementação produtiva. Ela precisa de juízo para avaliar
corretamente os casos concretos. Conhecemos essa função do juízo
sobretudo a partir da jurisprudência, campo em que o desempenho
jurídico complementar da 'hermenêutica' reside justamente em
promover a concreção do direito."2

Em Direito Constitucional, mais do que em qualquer outro ramo da ciência jurídica, a tarefa interpretativa assume especial e particular relevância. Isto se dá não só pela maior presença de princípios e de conceitos indeterminados, como

\footnotetext{
${ }^{1}$ Manuel A. Domingues de Andrade, Ensaio sobre a Teoria da Interpretação das Leis, 1987, p. 9.

${ }^{2}$ Ob. cit, p. 87.
} 
também pela proeminência das normas constitucionais, que por sua própria natureza espraiam seu conteúdo e significado por todas as províncias do território jurídico.

Nesse sentido, Konrad Hesse afirma que "a interpretação tem significado decisivo para a consolidação e preservação da força normativa da Constituição". 3

Como assinala Uadi Lammêgo Bulos,

"A interpretação constitucional é, em nossos dias, dos maiores desafios colocados para o aplicador do Direito e um dos campos mais fecundos e prioritários do labor científico dos juristas. Constitui o coração dos debates constitucionais."

Para Rubio Llorente, "a Teoria da Interpretação é hoje o núcleo essencial da Teoria da Constituição"; e porque “o Estado contemporâneo é precisamente Estado Constitucional, o problema da interpretação é também o problema central da Teoria do Estado" e, em certa medida, da própria Teoria do Direito. 5

Tão grande proeminência leva Inocêncio Mártires Coelho a proclamar que "a hermenêutica constitucional transformou-se na teoria do conhecimento jurídico ou, se preferirmos, no conhecimento do conhecimento do direito, porque incumbe a ela - ciência de si mesma - a supertarefa de interpretar as diferentes interpretações do fenômeno jurídico". 6

O modo e o alcance da interpretação constitucional constituem ponto nevrálgico para a própria configuração do Estado Democrático, tendo em vista a

\footnotetext{
${ }^{3}$ A Força Normativa da Constituição, p. 22.

${ }^{4}$ Curso de Direito Constitucional, p. 325.

${ }^{5}$ F. Rubio Llorente, prefácio a La Interpretación de la Constitución, de Enrique Alonso García, Madri, 1984.

${ }^{6}$ Curso de Direito Constitucional (em co-autoria com Gilmar Mendes e Paulo Gonet Branco), $5^{\text {a }}$. ed., 2010, p. 194.
} 
inevitável tensão entre a judicial review e a representação popular institucionalizada nos parlamentos, que não raro tem levado a questionamentos quanto à legitimidade da jurisdição constitucional (a chamada "dificuldade contra-majoritária”).

Nos Estados Unidos da América, um dos berços do moderno constitucionalismo, o debate sobre as técnicas de interpretação constitucional há muito superou os limites da academia ou dos tribunais, ganhando espaço dentre os assuntos que cotidianamente interessam ao cidadão. O tema tem sido abordado até mesmo em campanhas presidenciais; nenhum candidato, nas últimas décadas, deixa de se manifestar sobre os critérios que adotará para selecionar juízes para a Suprema Corte e para o Judiciário Federal, mencionando direta ou indiretamente a tendência de interpretação constitucional dos possíveis nomeados como um dos pré-requisitos para a nomeação ${ }^{7}$.

Há, naturalmente, várias tendências e doutrinas de interpretação no constitucionalismo americano, dentre as quais podemos destacar: a idéia da "Constituição viva" (living Constitution), a "leitura moral", o realismo, o pragmatismo, para citar apenas alguns.

Nenhuma dessas escolas ou teorias, porém, gerou tanta repercussão e debate como o originalismo, que procura na intenção dos Pais Fundadores, ou no entendimento original da Constituição ao tempo em que adotada, a chave para interpretação de seus dispositivos. Por mais de duas décadas, o originalismo vem desempenhando "um papel central no debate sobre a própria estrutura do direito constitucional". ${ }^{8}$ Tanto é assim, que se costuma dividir os intérpretes da Constituição - notadamente juízes e professores de Direito Constitucional - em dois grandes grupos: os originalistas e os não-originalistas.

\footnotetext{
${ }^{7}$ Já na década de 1960, durante a campanha eleitoral, Richard Nixon afirmava que somente nomearia "strict constructionists" (na linguagem da época, a referência era a juízes que respeitassem o papel reservado aos legisladores). O critério de nomeações para a Suprema Corte também foi um dos mais importantes na campanha presidencial de Ronald Reagan. Em data recente, o presidente Barack Obama declarou, ao surgir a primeira vaga para Suprema Corte em seu período presidencial, com a aposentadoria do juiz David Souter, que escolheria "alguém que compreenda que a justiça não trata [somente] de alguma teoria legal abstrata ou notas de rodapé em um registro de jurisprudência, mas também como nossas leis afetam a realidade diária da vida das pessoas" (The Washington Post, 2.5.2009, edição eletrônica).

${ }^{8}$ Earl Maltz, Rethinking Constitutional Law, p. 15. No mesmo sentido, Chemerinsky, Constitutional Law, p. 17.
} 
A extraordinária importância dessa matéria em um dos berços do moderno constitucionalismo já justificaria, por si, um estudo monográfico. No entanto, a pesquisa preliminar indicou-nos um motivo adicional, uma vez que verificamos que esse enfoque interpretativo, ainda que com diferente intensidade, também está presente em outros países, inclusive no Brasil.

Surgiu-nos então a idéia de abordar o tema de uma perspectiva diferente: não nos deter apenas no originalismo norteamericano, mas examinar como tem sido sua aplicação em outras culturas jurídicas e, sobretudo, verificar em que medida ele pode contribuir para o estudo das questões constitucionais brasileiras.

Há ainda outra ordem de considerações a fazer. Algumas vozes em nossa doutrina começam a manifestar preocupação contra os excessos do ativismo judicial e seu principal instrumento prático - uma interpretação jurídica instável, extremamente maleável e imprevisível, orientada pelo ideal de "realização da Justiça" (na verdade, aquilo que parece mais justo ao intérprete ou ao julgador), relegando a segundo plano os textos normativos. ${ }^{9}$

Este problema é enfrentado há décadas nos Estados Unidos, e um dos principais mecanismos para enfrentá-lo tem sido, precisamente, a defesa da interpretação originalista, que atua como meio de auto-contenção judicial.

Também por esse terceiro e igualmente importante aspecto, justifica-se o tema escolhido.

Por essas razões, propomo-nos a estudar o originalismo sob essa nova perspectiva, almejando assim contribuir para o aperfeiçoamento das técnicas de interpretação constitucional e a cultura jurídica brasileira.

O trabalho consistirá, afora esta breve introdução, de cinco capítulos.

\footnotetext{
${ }^{9}$ Nesse sentido: Dimitri Dimoulis, Positivismo Jurídico, pp. 58-63; $\quad$ Elival da Silva Ramos, Parâmetros Dogmáticos do Ativismo Judicial em Matéria Judicial (tese, USP, 2009) ; vide também "Ativismo Judicial é ruim independente do resultado" - entrevista desse autor ao site Consultor Jurídico em 1.8.2009.
} 
No primeiro, abordaremos alguns aspectos da atividade interpretativa em geral e da interpretação constitucional, mencionando os principais métodos de interpretação jurídica e as características e critérios específicos da interpretação em matéria constitucional, com vistas a compreender a posição do originalismo nesse quadro.

No segundo capítulo, trataremos do originalismo no contexto norteamericano, verificando as razões de seu surgimento e o modo como tem ocorrido sua evolução, expondo os argumentos de seus partidários e as principais críticas que lhe são dirigidas.

A presença do olhar originalista em outros países será objeto do terceiro capítulo.

A parte principal do trabalho tratará do enfoque originalista no Brasil. O capítulo quarto examinará o período anterior a 1988, enquanto que as questões mais recentes, já sob a vigência da atual Constituição, serão objeto do quinto e último capítulo, seguindo-se as conclusões gerais.

A tese que se objetiva desenvolver pode ser desde logo sintetizada em três idéias fundamentais: (a) a importância do originalismo, (b) sua utilidade como critério complementar a outras técnicas de interpretação e (c) sua eficácia como freio aos excessos do ativismo judicial, no estágio atual do constitucionalismo brasileiro. 


\section{CAP. 1 - ALGUMAS REFLEXÕES SOBRE A INTERPRETAÇÃO DAS LEIS E DA CONSTITUIÇÃO.}

\subsection{A interpretação e seus limites.}

Os dicionários Aurélio e Houaiss indicam que interpretar, em sua primeira e principal acepção, consiste em determinar o significado preciso de um texto ou uma lei.

Observa-se na generalidade das ciências humanas a existência de uma preocupação de que o intérprete, ao determinar o sentido de um texto, não extrapole aquilo que dele se espera, ou seja: que revele e torne mais claro o conteúdo do objeto de análise, sem adicionar-lhe preferências pessoais ou distorcer seu "verdadeiro" significado.

Nietzsche queixou-se certa vez que já "não existem fatos, só interpretações" ${ }^{10}$, lamentando o encobrimento da realidade (ou do sentido real e verdadeiro) por sucessivas camadas de versões e entendimentos subjetivos.

Nos domínios da crítica artística, essa preocupação é bem retratada por Susan Sontag:

“O estilo moderno de interpretação escava e, à medida que escava, destrói; cava debaixo do texto, para encontrar um subtexto que seja verdadeiro. (...)

Interpretar é empobrecer, esvaziar o mundo - para erguer, edificar um mundo fantasmagórico de significados. É transformar o mundo nesse mundo. (...)

Nossa tarefa não é descobrir o maior conteúdo possível numa obra de arte, muito menos extrair de uma obra de

\footnotetext{
${ }^{10}$ Fragmentos Póstumos, 7. O filósofo também reclama de excessos na interpretação de seus próprios o textos $\$ 22$ de Para além do bem e do mal.
} 
arte um conteúdo maior do que já possui. Nossa tarefa é reduzir o conteúdo para que possamos ver a coisa em si."

Nessa seara, por sinal, é altamente significativo que Umberto Eco, ele próprio criador do conceito de obra aberta - ao qual é inerente a idéia de que toda obra de arte contempla múltiplas interpretações - em livro escrito três décadas mais tarde, sugestivamente intitulado Os limites da interpretação, apontava que no instável equilíbrio entre a "iniciativa do intérprete" e a "fidelidade à obra" a balança pendera excessivamente para o primeiro lado, sendo necessário, se não restaurar o equilíbrio, ao menos "sublinhar a ineliminabilidade da oscilação"12.

A própria ficção literária encarrega-se, por vezes, de ilustrar que s pode encontrar argumentos para defender qualquer tese, o que nos deve colocar de sobreaviso contra interpretações direcionadas por interesses ou preferências do próprio intérprete. "O comentário da lei é a eterna malícia", nos diz Machado de Assis, com sua habitual e fina ironia, no conto A Sereníssima República. ${ }^{13}$

\subsection{A interpretação no direito}

A interpretação, conforme ensina Manoel Gonçalves Ferreira Filho, "consiste em determinar o sentido e o alcance da norma, a partir da compreensão do enunciado que a exprime"; mas, adverte o mesmo autor, essa atividade tem como pressuposto a boa-fé do intérprete, que "deve procurar o que o

\footnotetext{
${ }^{11}$ Susan Sonntag, Contra a Interpretação, pp.15-16 e 23.

${ }^{12}$ Umberto Eco, Os limites da interpretação, Perspectiva, 1995, p. XXII (o original é de 1992). Obra Aberta foi publicada em 1962.

13 Esse texto está incluído na obra Papéis Avulsos. E cremos que uma breve referência a seu enredo é cabível, pois o autor parece nos alertar (e aqui já vai uma certa interpretação de nossa parte...) não haver limites para a criatividade dos intérpretes. Trata-se de uma fábula relatando a organização de uma comunidade aracnídea, que escolhe seu dirigente máximo na forma de sorteio, o mais democrático método de eleição. Há dois candidatos disputando a vaga, "Nebraska" e "Caneca". É sorteado o nome do primeiro, gravado porém de forma incorreta, sem a letra final ("Nebrask"). Um sábio "filólogo", que também era "bom metafísico, e não vulgar matemático", como nos informa o narrador, consegue habilmente "provar" aos juízes do pleito que essa grafia indicaria, em verdade, o outro candidato (!), que acaba sendo o escolhido. Como desfecho e possível moral da estória, a comunidade decide mudar a lei, abolindo-se a "faculdade interpretativa dos textos".
} 
legislador quer, não aquilo que lhe parece melhor, ainda que mais justo". Por isso mesmo, conclui, é "um ato de conhecimento, não de vontade". ${ }^{14}$

Esse conceito afina-se com a lição dos clássicos. Ferrara, por exemplo, diz que a missão do intérprete é "descobrir o conteúdo real da norma jurídica" 15 , enquanto Betti salienta que "onde quer que nos encontremos na presença de manifestações objetivas, por meio das quais outro espírito fala ao nosso, apelando para a nossa compreensão, entra em movimento a nossa atividade interpretativa para entender qual sentido têm essas manifestações e o que querem nos dizer". ${ }^{16}$

Para Karl Larenz, a missão do intérprete é mediar a compreensão do sentido de um texto, em busca de seu significado correto. ${ }^{17}$

Embora saibamos que esse ponto não está isento de controvérsias, consideramos importante realçar que também consideramos a interpretação como um ato de descoberta do significado, e não de sua construção ou atribuição por parte do intérprete/mediador, segundo suas preferências ou inclinações pessoais, o que implica desde logo reconhecer a necessidade de reconhecer limites à atividade interpretativa.

É certo que a aplicação da norma jurídica não se esgota com sua interpretação. A norma frequentemente incidirá sobre situações não previstas pelo legislador. Aí não se trata, porém, de construir novos significados para a norma, mas de aplicá-la por meio de analogia ou outro recurso integrativo a situações da vida real. Importante, por isso, não mesclar os conceitos de interpretação, aplicação e integração. A aplicação, ensina Celso Bastos, decorre da seleção da norma que deve regular o caso a ser apreciado. A aplicação torna possível a interpretação, que é a reconstrução do conteúdo da norma. A integração, por sua vez, é um processo posterior, de preenchimento de lacunas do ordenamento jurídico. ${ }^{18}$

\footnotetext{
${ }^{14}$ Manoel Gonçalves Ferreira Filho, Curso de Direito Constitucional, 31 a . ed., p. 378.

${ }^{15}$ Interpretação e Aplicação das Leis, Coimbra, 1987, § 4.

${ }^{16}$ Interpretação da lei e dos atos jurídicos, Martins Fontes, 2007, p. XXXIII.

${ }^{17}$ Metodologia da Ciência do Direito, $5^{a}$. ed., 2009, pp. 282-289.

${ }^{18}$ Hermenêutica e Aplicação do Direito, 18 ${ }^{\mathrm{a}}$. ed., Forense, 1999, pp. 32-38.
} 
Essa distinção é de suma importância, porque evitará equívocos como o de atribuir, àqueles que buscam compreender o sentido original de uma norma, o propósito de "petrificar" seu significado e impedir sua atualização. Na verdade, a descoberta ou compreensão do sentido de uma norma é apenas o primeiro passo para sua aplicação, e não impede - antes, é um pressuposto - para sua atualização diante de novas circunstâncias, inexistentes à época da promulgação da lei ou simplesmente não previstas pelo legislador.

\subsection{Hermenêutica e interpretação}

Carlos Maximiliano inicia o clássico Hermenêutica e Aplicação do Direito alertando para a questão terminológica. “A Hermenêutica”, diz ele, é a ciência que "tem por objeto o estudo e a sistematização dos processos aplicáveis para determinar o sentido e o alcance das expressões do Direito", ao passo que a Interpretação é a arte ou técnica de extrair esse sentido e esse alcance: " $A$ Hermenêutica é a teoria científica da arte de interpretar" 19

Emílio Betti já definia a hermenêutica como uma ciência que tem por objeto uma reflexão crítica sobre o processo interpretativo ou, dito de modo mais simples, uma "teoria geral da interpretação". ${ }^{20}$

Celso Bastos é do mesmo pensar: a hermenêutica trata de "regras sobre regras jurídicas", de "enunciados" de caráter teórico-jurídico, enquanto que a interpretação é sempre pragmática e concreta, exercida diante de um problema que reclama solução. ${ }^{21}$

\footnotetext{
${ }^{19}$ Hermenêutica e Aplicação do Direito, cit., p. 1. No mesmo sentido: Limongi França, Hermenêutica Jurídica, Saraiva, $7^{\text {a }}$ ed., 1999, pp.3-4; Linares Quintana, Tratado de Interpretación Constitucional, t. I, Abeledo Perrot, $2^{\text {a }}$. ed., 2008, p. 5 (citando Carlos Maximiliano).

${ }^{20}$ Interpretação da lei e dos atos jurídicos, Martins Fontes, 2007, p. XCVIII.

${ }^{21}$ Hermenêutica e Interpretação Constitucional, 2a . ed., 1999, p. 21.
} 
Miguel Reale, no entanto, considera essa distinção sem utilidade prática, dada a "natureza necessariamente concreta do ato interpretativo". ${ }^{22}$

Também García Belaunde considera que os termos são equivalentes e podem ser utilizados como sinônimos, sendo cada vez mais freqüente o uso de interpretação. ${ }^{23}$

Adotamos esta última ao longo deste trabalho, especialmente porque nossa análise será preferencialmente voltada para casos e hipóteses concretas.

\subsection{Métodos ou elementos clássicos de interpretação}

Método, como define Linares Quintana, é o "caminho a seguir, o conjunto de procedimentos que o espírito humano deve empregar na busca e na demonstração da verdade". ${ }^{24}$ Nesse sentido é em Lógica fala-se nos métodos dedutivo e indutivo como formas, caminhos para se chegar ao conhecimento.

Não se deve confundir o conceito de método com o de técnica ou enfoque, que designa os infinitos modos de aproximação (approach) ao objeto que se pretende conhecer. $^{25}$

É usual a referência, na ciência jurídico a quatro métodos clássicos de interpretação - gramatical, lógico, histórico e sistemático, que foram definidos por Savigny (sob a denominação de elementos), no clássico Sistema do Direito Romano Atual, publicado entre 1840 e 1849, nos seguintes termos:

${ }^{22}$ O Direito como Experiência, Saraiva, 1968, p. 238.

${ }^{23}$ La Interpretación Constitucional como Problema, citado por Linares Quintana, Tratado de Interpretación Constitucional, 2008, t. I, p. 7.

${ }^{24}$ Tratado de Interpretación Constitucional, v. I.,2ı. ed., Buenos Aires, 2008, p. 163.

${ }^{25}$ Linares Quintana, ob. cit., p. 190. 
“O elemento gramatical da interpretação tem por objeto as palavras de que se serve o legislador para nos comunicar seu pensamento, ou seja, a linguagem das leis.

O elemento lógico, a decomposição do pensamento ou as relações lógicas que unem suas diferentes partes.

O histórico tem por objeto o estado do direito existente sobre a matéria, na época em que a lei foi editada; determina o modo de ação da lei e a mudança introduzida por ela, que é precisamente o que o elemento histórico deve esclarecer.

Por último, o elemento sistemático tem por objeto o laço íntimo que une as instituições e regras do direito no seio de uma vasta unidade. O legislador tinha diante de seus olhos tanto esse conjunto como os fatos históricos e, por conseguinte, para apreciar por completo seu pensamento, é necessário explicar claramente a ação exercida pela lei sobre o sistema geral do direito e o lugar que ela ocupa nesse sistema". ${ }^{26}$

Savigny esclarece que a denominação "elementos" é mais adequada porque não se trata de "quatro tipos de interpretação"; esta é um processo unitário que engloba aquelas "quatro operações distintas, cuja reunião é indispensável para interpretar a lei". Embora em algumas circunstâncias se possa omitir algum deles, "quando sua menção seja inútil ou pedante", os quatro são igualmente importantes. $^{27}$

Karl Larenz, aprofundando a análise desses quatro elementos, aponta sua necessária inter-relação, não devendo o intérprete escolher um deles arbitrariamente, mas sim ponderar os diferentes ângulos de análise. ${ }^{28}$

\footnotetext{
${ }^{26}$ Sistema del Derecho Romano Atual, t. I, Madri, 1878, p. 150.

27 Sistema, cit., v. I, pp. 150-151.

${ }^{28}$ Metodologia da Ciência do Direito, cit., pp. 450 e 484-485.
} 
Miguel Reale também salienta que não deve haver uma progressão entre os citados critérios, partindo-se, por exemplo, da análise gramatical para, em estágios ulteriores, chegar à análise sistemática. Os elementos de análise estão mutuamente imbricados e implicam-se reciprocamente, daí resultando o caráter unitário do processo de interpretação. ${ }^{29}$

\subsection{Objetividade e subjetividade da interpretação}

A chamada teoria subjetivista, que indagava a vontade do legislador como critério preponderante para interpretação das leis, teve grande influência até o século XIX, sendo defendida por grandes juristas, como Windscheid e Ennecerus. $^{30}$

Uma vez que a interpretação bíblica muito influenciou a interpretação jurídica em seus primórdios ${ }^{31}$, parece-nos apropriado salientar que na encíclica Divino Afflante Spiritu, em seu parágrafo n. 19, o Papa Pio XII proclamou que "ninguém ignora que a norma suprema da interpretação é indagar e definir que coisa se propôs dizer o escritor". Essa diretriz é até hoje seguida no Direito Canônico, cujo Código contempla expressamente a intenção do legislador como critério interpretativo para descobrir o significado das normas. ${ }^{32}$

\footnotetext{
${ }^{29}$ Lições Preliminares de Direito, Saraiva, 24a . ed., 1998, p. 294.

${ }^{30}$ Karl Larenz, Metodologia da Ciência do Direito, 5ª . ed., 2009, p. 445.

31 José Reinaldo Lima Lopes, O Oráculo de Delfos, Saraiva, 2010, p. 25.

32 “Cânon 17 - As leis eclesiásticas devem ser entendidas segundo o sentido próprio das palavras, considerado no texto e no contexto; mas, se o sentido continua duvidoso e obscuro, deve-se recorrer aos lugares paralelos, se os houver, à finalidade e às circunstâncias da lei, bem como à mente do legislador". Ao comentar essa norma, o padre Jesús Hortal, S.J., anotador da tradução brasileira do citado Código, editada pela CNBB, defende até mesmo que " quando a finalidade da lei e a mente do legislador são claramente conhecidos, deveriam prevalecer sobre a materialidade das palavras".
} 
A posição contrária - hoje certamente dominante - sustenta que o intérprete deve buscar o sentido objetivo da lei, que pode até não coincidir com a vontade daqueles que a editaram. Ferrara já o expressara: "o intérprete deve buscar não aquilo que o legislador quis, mas aquilo que na lei aparece objetivamente querido: a mens legis e não a mens legislatoris". 33

No mesmo sentido, informa Silvio Rodrigues que desde a publicação da obra Método de Interpretação e Fontes em Direito Positivo Privado, de François Gény, em 1899, considera-se um erro procurar na lei “apenas a vontade do legislador ${ }^{, 34}$, dando-se preferência à busca de seus fins. ${ }^{35}$

No entanto, adverte Karl Larenz que não se deve de modo algum colocar de lado a análise desse elemento, pois "o sentido da lei que há de ser considerado juridicamente determinante tem de ser estabelecido atendendo às intenções de regulação e às idéias normativas concretas do legislador histórico, e, de modo nenhum, independentemente delas." 36

A síntese mais adequada entre essas duas tendências, demonstrando sua falsa oposição, é feita por Alf Ross:

"Frequentemente se faz uma distinção entre as assim chamadas interpretação subjetiva e interpretação objetiva, no sentido de que a primeira procura descobrir o significado que se quis expressar, isto é, a idéia que inspirou o autor e que este quis comunicar, enquanto a segunda procura estabelecer o significado comunicado, isto é, o significado que está na comunicação como tal, considerada como um fato objetivo. (...)

\footnotetext{
33 Interpretação e Aplicação das Leis, cit., $§ 6$.

${ }^{34}$ Silvio Rodrigues, Direito Civil-Parte Geral, Saraiva, 17 a ed., 1987, p. 26.

${ }^{35}$ Veja-se que $\mathrm{o}$ art. $5^{\circ}$ da Lei de Introdução ao Código Civil dispõe: Na aplicação da lei, o juiz atenderá aos fins sociais a que ela se dirige e às exigências do bem comum.

${ }^{36}$ Medotologia da Ciência do Direito, cit., p. 448.
} 
Tomada assim, como um contraste absoluto entre intenção e comunicação, entre o que se quer dizer e o que se diz, a distinção é insustentável. De um lado, a intenção, como fenômeno interno de consciência, é fundamentalmente inacessível. O que entendemos por interpretação subjetiva é na verdade a interpretação que alcançamos quando tomamos em consideração não apenas a expressão lingüística, mas todos os outros dados relevantes: o contexto e a situação, que inclui as opiniões políticas e filosóficas do autor, os propósitos declarado e presumido que o guiaram ao formular a expressão, e assim por diante. (...) Por outro lado, a comunicação como tal não tem um significado objetivo preciso, a compreensão que suscita nas demais pessoas varia com os dados de interpretação que o destinatário toma em conta.

A diferença entre interpretação subjetiva e objetiva, portanto, não deve ser buscada no contraste entre os propósitos da interpretação (o significado pretendido como algo oposto ao significado comunicado). Toda interpretação parte da comunicação e procura chegar à intenção. A diferença depende dos dados que se tomam em conta ao interpretar. A interpretação subjetiva vale-se de todas as circunstâncias que podem lançar luz sobre o significado (...) A interpretação objetiva limita os dados àqueles que são discerníveis pelo destinatário na situação em que se acha ao apreender a expressão. (....) A interpretação objetiva simplesmente se recusa a investigar a intenção estudando a maneira em que a obra foi produzida. De tal modo, a interpretação objetiva - em óbvio contraste com o que a terminologia autorizaria a crer - adquire um tom de maior inexatidão e arbitrariedade que a interpretação subjetiva., ${ }^{37}$

${ }^{37}$ Alf Ross, Sobre el Derecho y la Justicia, Buenos Aires, 1958, pp. 117-118. Os destaques são nossos. 


\subsection{Conceito de interpretação constitucional}

Não há uniformidade no emprego do conceito de interpretação constitucional. Há quem o utilize para significar a atividade interpretativa de um único órgão - o Tribunal Constitucional (Ezquiaga Ganuzas), ou para referir-se ao conjunto de decisões de controle de constitucionalidade proferidas pelo Tribunal Constitucional (Igartúa Salaverría). Para outros, como Pérez Nuño, não se trata de interpretar "a" Constituição, mas "a partir" dela, utilizando-a como ponto de partida para compreensão de todo o ordenamento jurídico. Para Alonso García, trata-se do processo de criação judicial de "normas subconstitucionais". ${ }^{38}$

Rodolfo Luís Vigo adota um conceito duplo: por interpretação constitucional deve-se entender: (a) o processo pelo qual se procura atribuir um sentido jurídico ao texto da Constituição; ou (b) fixar o sentido de uma norma ou comportamento em relação à Constituição. ${ }^{39}$

Na doutrina brasileira, Inocêncio Mártires Coelho salienta que a interpretação constitucional é a mais relevante espécie de interpretação jurídica, e consiste em "fixar o sentido das normas da lei fundamental - sejam essas normas regras ou princípios - tendo em vista resolver problemas práticos, se e quando a simples leitura dos textos não permitir, de plano, a compreensão de seu significado e do seu alcance."

Celso Bastos, por sua vez, também defende uma concepção ampliada do objeto da interpretação constitucional, que deve abranger não só o texto da Constituição, mas também as normas infraconstitucionais, quando

\footnotetext{
${ }^{38}$ Autores citados por Rodolfo Luís Vigo, Interpretación Constitucional, pp. 81-83.

${ }^{39}$ Ob. Cit., pp. 83-84.

${ }^{40}$ Curso de Direito Constitucional (escrita em parceria com Gilmar Mendes e Paulo Gonet Branco), $5^{\mathrm{a}}$. ed., 2010, p. 155.
} 
confrontadas com o texto da Lei Maior, e as próprias decisões do Tribunal Constitucional, que acabam por se incorporar àquela. ${ }^{41}$

\subsection{Especificidade da interpretação constitucional.}

A interpretação constitucional, embora seja da mesma natureza que a interpretação jurídica geral ${ }^{42}$, tem peculiaridades, basicamente decorrentes da supremacia e rigidez da Constituição, de sua inicialidade, bem como do caráter político do Direito Constitucional. A presença desses fatores faz com que a definição do significado das normas constitucionais espraie-se por todo o ordenamento jurídico, ${ }^{43}$ delimitando não só relações intersubjetivas, mas principalmente a configuração do Poder do Estado.

Para alguns autores, a interpretação da Constituição não tem natureza diferente da interpretação das demais normas jurídicas. Uadi Lammêgo Boulos segue essa linha: para ele, "não há como seccionar a interpretação a ponto de admitir uma dogmática específica da exegese constitucional”, que seguiria os mesmos "cânones hermenêuticos" aplicáveis a toda a ciência jurídica; ademais, o caráter político estaria presente ao processo de elaboração das normas em geral. ${ }^{44}$

No entanto, é majoritária a corrente que proclama a especificidade da interpretação constitucional. ${ }^{45}$

\footnotetext{
${ }^{41}$ Hermenêtica e Interpretação Constitucional, cit., pp. 79-87.

${ }^{42}$ Manoel Gonçalves Ferreira Filho, Curso de Direito Constitucional, $31^{\mathrm{a}}$ ed., 2005, p. 383.

${ }^{43}$ Como assinala Celso Ribeiro Bastos, "a interpretação da norma constitucional é indispensável para a boa compreensão das demais normas que compõe o nosso ordenamento jurídico" (As Tendências do Direito Público, p. 77.)

${ }^{44}$ Curso de Direito Constitucional, $5^{\text {a }}$. ed., pp. 436-437.

${ }^{45}$ André Ramos Tavares, Curso, 8a. ed., p. 102; Celso Ribeiro Bastos, Hermenêutica e Interpretação Constitucional, pp. 49-52. Inocêncio Mártires Coelho, Interpretação Constitucional, p. 67; Rodolfo Luís Vigo, Interpretação Constitucional, p. 78.
} 
Como assinala Manoel Gonçalves Ferreira Filho, a natureza normativa da Constituição faz com que lhe sejam aplicáveis os mesmos métodos utilizados para a interpretação das demais normas jurídicas, desde que se leve em conta duas características próprias da Lei Maior: o fato de conter "os valores mais caros à comunidade" e a sua supremacia em relação às demais leis. ${ }^{46}$

A esses fatores, podemos acrescentar o grande número de princípios gerais albergados no texto constitucional como outra razão para se falar em critérios próprios de hermenêutica constitucional.

\subsection{Princípios e métodos de interpretação constitucional}

Deve-se a Canotilho a grande divulgação de um catálogo de princípios de interpretação constitucional que o mestre português foi buscar em Konrad Hesse e Friedrich Müller. São os seguintes:

a) princípio da unidade da constituição, pelo qual busca-se evitar contradições ou antinomias entre suas normas, pois estas não isoladas, compondo um sistema unitário;

b) princípio do efeito integrador, pelo qual devem ser procuradas "soluções pluralisticamente integradoras"; é na verdade um subproduto ou desdobramento do princípio da unidade;

c) princípio da máxima efetividade: o intérprete deve buscar o sentido que atribua a maior eficácia possível a um dispositivo da constituição; é costumeiramente invocado no trato dos direitos fundamentais;

${ }^{46}$ Curso de Direito Constitucional, $31^{\text {a }}$ ed, 2005, p. 383. 
d) princípio da justeza ou conformidade funcional: a interpretação não pode chegar a um resultado que "subverta ou perturbe o esquema organizatório-funcional constitucionalmente estabelecido", preservando a esfera de competência de cada um dos poderes; ${ }^{47}$

e) princípio da concordância prática ou da harmonização: também decorrente da idéia de unidade, significa que todos os bens e direitos consagrados pela Constituição são igualmente importantes; a proteção de um pode restringir outros, mas não a ponto de nulificá-los; trata-se, como salienta Inocêncio Mártires Coelho, de uma “recomendação para que o aplicador das normas constitucionais, em se deparando com situações de concorrência entre bens constitucionalmente protegidos, adote a solução que otimize a realização de todos eles, mas ao mesmo tempo não acarreta a negação de nenhum";

f) princípio da força normativa da constituição: parece-nos também um desdobramento dos anteriores, significando que a interpretação deve garantir a maior eficácia e aplicação do conjunto de todas as normas constitucionais.

A estes princípios, Inocêncio Mártires Coelho acresce outros três: o da proporcionalidade ou da razoabilidade, o da interpretação conforme a Constituição e o da presunção de constitucionalidade das leis. O primeiro é um princípio de ponderação, enquanto os outros dois dizem respeito, basicamente, ao controle de constitucionalidade das leis. ${ }^{49}$

Quanto aos métodos de interpretação constitucional, são cinco os enunciados por Canotilho. ${ }^{50}$

\footnotetext{
${ }^{47}$ Canotilho, ob.cit., p. 1188. Comentando esse princípio, Inocêncio Mártires Coelho ressalta que as Cortes Constitucionais, Parlamento e Executivo devem buscar a superação de suas naturais divergências, de modo a preservar tanto a legitimidade democrática do legislador como a função dos tribunais como supremos intérpretes, sempre tendo em vista a necessidade maior de guardar-se a fidelidade à Constituição (Curso, cit, p. 177).

${ }^{48}$ Curso de Direito Constitucional (obra em co-autoria com Gilmar Mendes e Paulo Gonet Branco), $5^{\text {a }}$. ed., Saraiva, 2010, pp. 174-175.

${ }^{49}$ Curso, cit., p. 170.

${ }^{50}$ Direito Constitucional e Teoria da Constituição, 4a. ed., pp.1174-1178.
} 
O primeiro, que denomina de jurídico ou hermenêuticoclássico, engloba elementos tradicionais de interpretação: gramatical, histórico, lógico e sistemático. Foi proposto por Ernest Forsthoff, com base no postulados de que a Constituição deve ser tratada essencialmente como uma lei (ou seja, é uma norma jurídica como as demais); suas particularidades, que são inegáveis, não afastam a aplicabilidade daqueles elementos interpretativos clássicos. Interessante notar que os partidários desse método alertam que, se for desprezada a natureza legal da Constituição, estará aberta a porta para o excesso de subjetivismo por parte dos juízes. O texto da Constituição não é apenas o ponto de partida, mas também o limite para a interpretação. O método não nega o caráter especial da Constituição Como salienta Canotilho, este método preconiza que "a função do intérprete será a de desvendar o sentido do texto sem ir para além, e muito menos contra, o teor literal do preceito". 51

O segundo é o método tópico-problemático, formulado por Theodor Viehweg, na obra Tópica e Jurisprudência, de 1953, tem como ponto de partida os problemas concretos a serem resolvidos, e a norma como ponto de chegada, invertendo os processos usuais de raciocínio. Topoi são esquemas de raciocínio ou formas de argumentação. O intérprete é considerado protagonista do processo de aplicação da Constituição, ${ }^{52}$ transformando a atividade interpretativa, em última análise, em um processo aberto de argumentação. ${ }^{53}$ Embora frequentemente adotado Tribunal Constitucional Federal da Alemanha ${ }^{54}$, e favorecido por autores como Pérez Royo $^{55}$ e Paulo Bonavides ${ }^{56}$, merece sérias reservas pelo seu caráter assistemático, podendo conduzir a um “casuísmo sem limites”, como bem aponta Canotilho. Na

\footnotetext{
${ }^{51}$ Ob. cit., p. 1175.

${ }^{52}$ Mendes, Coelho e Branco, Curso, p. 95.

${ }^{53}$ Canotilho, ob. cit., p. 1175.

${ }^{54}$ Böckenforde, Stato, costituzione, democrazia, p. 72 (especialmente nota n. 25). No Supremo Tribunal Federal, método similar é declaradamente adotado pelo ministro Marco Aurélio: "Idealizo para o caso concreto a solução mais justa e posteriormente vou ao arcabouço normativo, vou à dogmática buscar o apoio", completando que, a seu ver, "a interpretação é acima de tudo um ato de vontade" (discurso em solenidade no Supremo Tribunal Federal, 17.6.2010; disponível em http://www.conjur.com.br/2010-jul-06/idealizo-solucao-justa-depois-vou-ar-normas-marco-aurelio.

${ }^{55}$ Curso de Derecho Constitucional, Marcial Pons, 2007, pp. 124-128.

56 método tópico de interpretação constitucional, em Lições de Direito Constitucional em Homenagem ao Jurista Celso Bastos, Saraiva, 2005, pp. 1-9.
} 
verdade, há um claro erro conceitual em sua formulação, pois “a interpretação não deve partir do problema para a norma, mas desta para os problemas ",57

Vem a seguir o método hermenêutico-concretizador, idealizado por Konrad Hesse. Mesmo reconhecendo que o intérprete parte de uma précompreensão do texto, esse método almeja a concretização da norma constitucional a partir de uma determinada situação histórica, porque não há interpretação sem referência a problemas concretos. O método postula a primazia da norma sobre $\mathrm{o}$ problema, mas trata a interpretação e a aplicação de forma unitária, não escapando da tendência para um certo casuísmo. ${ }^{58}$

O quarto método mencionado é científico-espiritual, inspirado na idéia de integração da comunidade, defendida por Rudolf Smend. É também chamado de valorativo, sociológico ou integrativo. Centra-se na análise dos valores subjacentes à Constituição, a partir da realidade social. Vê a Constituição como um produto cultural da sociedade, conferindo grande elasticidade a suas normas. É sem dúvida uma interpretação de cunho marcadamente político ${ }^{59}$, e "seu fundamento filosófico-jurídico também não é claro"60

O quinto método é o normativo-estruturante, preconizado por Friedrich Müller ${ }^{61}$, a partir de uma distinção entre o norma e texto normativo. Este é apenas uma diretriz e limite das possibilidades de concretização do direito. A interpretação da Constituição seria, na verdade, a sua concretização, e para alcançá-los é preciso levar em conta não somente os elementos jurídicos, mas também a realidade

\footnotetext{
${ }^{57}$ Canotilho, ob. cit., pp. 1175-1176.

${ }^{58}$ Paulo Bonavides, Curso, p. Marcelo Novelino, Direito Constitucional, $3^{\mathrm{a}}$. ed., p. 156.

${ }^{59}$ Paulo Bonavides, Curso,

${ }^{60}$ Canotilho, ob. cit., p. 1177.

${ }^{61}$ Friedrich Müller, Métodos de trabalho do direito constitucional, Max Limonad, $2^{\mathrm{a}}$ ed., 2000; O novo paradigma do direito, RT, 2008.
} 
social. Canotilho revela simpatia por este método, adotando-lhe algumas de suas premissas. $^{62}$

\subsection{A complementaridade dos métodos}

Seja na interpretação jurídica em geral, seja especificamente nos domínios da interpretação constitucional, é preciso ter em mente a impossibilidade de conceder exclusividade a um único método, em detrimento dos demais.

Linares Quintana já se posicionava, em 1953, decididamente contrário à "pureza metodológica" no estudo do direito constitucional, que levaria inevitavelmente a um resultado unilateral e incompleto. ${ }^{63}$

De maneira semelhante, Canotilho ressalta que a atual interpretação constitucional caracteriza-se por um conjunto de métodos, considerandoos "reciprocamente complementares". 64

Uadi Lammêgo Bulos, ao propor uma nova nomenclatura, chamando de artifícios hermenêuticos o conjunto de normas, princípios e técnicas ${ }^{65}$ de interpretação, também salienta o a necessidade de seu emprego conjunto, pois nenhum

\footnotetext{
${ }^{62}$ Ob. cit., p.1177, nota 11.

${ }^{63}$ Segundo V. Linares Quintana, Tratado de la Ciência del Derecho Constitucional, v. I, n. 587, p. 442. ${ }^{64}$ Ob. cit., p. 1174.

65 Técnicas seriam, para esse autor, ferramentas auxiliares para a descoberta do significado e das conexões de sentido entre as normas constitucionais, das quais ele menciona: a ponderação de interesses, a otimização de princípios e a chamada filtragem constitucional (leitura de todo o ordenamento segundo a óptica constitucional) - Curso, cit. p. 450.
} 
pode, isoladamente, "fornecer critério exato e perfeito para a exegese constitucional". 66

Luis Roberto Barroso também assinala que "nenhum método deve ser absolutizado; os diferentes meios empregados ajudam-se uns aos outros, combinando-se e controlando-se reciprocamente" ${ }^{67}$

Ainda nesse tópico, consideramos particularmente enriquecedora a análise feita por Paulo de Barros Carvalho, situando os diversos métodos de interpretação jurídica em três planos distintos: o sintático, o semântico e o pragmático.

O plano sintático diz respeito ao relacionamento interno das normas; o plano semântico trata da relação entre as normas e os fatos e condutas a que elas se referem, e o plano pragmático lida com a efetiva aplicação das normas (sem bem compreendemos o pensamento do ilustre autor, aqui estamos a considerar as conseqüências da interpretação).

Nessa interessante classificação, os métodos literal e lógico estão no nível sintático; os métodos histórico e teleológico operam nos planos semântico e pragmático, enquanto o método sistemático envolve os três planos. Conclui então Paulo de Barros Carvalho: "a exegese dos textos legais, para ser completa, tem de valer-se de incursões nos níveis sintático, semântico e pragmático da linguagem jurídica, única forma de se chegar ao conteúdo intelectual". ${ }^{68}$

Todos os métodos, na verdade, se propõem a oferecer um embasamento seguro à difícil tarefa do intérprete. Inegável a importância de que sejam coerentemente formulados e aplicados, pois como assinala Jerzy Wróblewski, " $a$ interpretação constitucional deve apresentar-se como uma decisão interpretativa apropriadamente justificada". 69

\footnotetext{
${ }^{66}$ Curso, cit. p. 440.

${ }^{67}$ Interpretação e Aplicação da Constituição, , Saraiva, 7ª ed., 2009, p. 129.

${ }^{68}$ Paulo de Barros Carvalho, Direito Tributário, Linguagem e Método, 3a . ed., 2009, pp. 198-201.

${ }^{69}$ Jerzy Wróblewski, Constitución y Teoría General de la Interpretación Jurídica, p.. 114.
} 
E além de "apropriadamente justificada", a interpretação constitucional deve ser exercida com a consciência de que, sendo "uma interpretação de limites" impostos ao legislador, ela própria "também tem seus limites", uma vez que "não se pode desnaturar o texto constitucional pela via da interpretação". 70 Este pensamento terá particular importância quando examinarmos, mais adiante, o problema do ativismo judicial.

\subsection{A importância da "vontade do constituinte"}

Retomando, agora no plano constitucional, a tradicional dicotomia entre interpretação objetiva e subjetiva (lembrando a falsa oposição entre elas, segunda a mencionada lição de Alf Ross), partiremos do conhecido aforismo, segundo o qual a lei é mais inteligente que o legislador.

Ensina Ives Gandra da Silva Martins que tal pensamento é altamente questionável na seara do direito constitucional:

“À evidência, as palavras e a intenção do constituinte têm particular relevância na exegese do direito supremo. Se, no plano da legislação infraconstitucional, a lei é mais inteligente que o legislador — pois a norma é interpretada à luz do antecedente constitucional —, a Constituição não é mais inteligente que o onstituinte, pois o antecedente da norma constitucional é a vontade dele."71

Em outro trabalho, o mesmo autor reafirma esse ponto:

\footnotetext{
${ }^{70}$ Javier Perez Royo, Curso de Derecho Constitucional, Madri, Marcial Pons, 2007, p. 128.

${ }^{71}$ Manipulação de patrimônio genético à luz da Constituição Federal e da MP 2186-16/2001 in Revista Justiça \& Cidadania, edição 120, julho 2010, pp. 8-13.
} 
"Pode-se dizer que a lei é mais inteligente que o legislador, pois o texto de lei não deve ser examinado à luz do que deseja aquele que a elabora, mas do sistema constitucional vigente. Já a Constituição não é mais inteligente que o constituinte, pois o constituinte é o único antecedente ao texto supremo. A lei tem como antecedente, a Constituição. A Constituição tem como antecedente o constituinte. Por esta razão, a vontade do constituinte deve ser levada em consideração." 72

Esta diferenciação parece-nos de capital importância. A posição do constituinte é peculiar, pois está ele investido do poder de exprimir, em nome de todo o povo, o conjunto de decisões fundamentais, que irão constituir a base de todo o ordenamento jurídico, como estatuto básico a reger os destinos de uma coletividade. Essas decisões, embora não sejam imutáveis, destinam-se a perdurar no tempo, e não devem ficar expostas a demasiadas oscilações interpretativas.

As leis comuns inserem-se num sistema normativo, havendo necessidade de harmonizar a interpretação de cada uma das partes com o todo. E todas elas haverão de ser interpretadas à luz da norma que lhes é superior, daí podendo advir correções e adaptações de sentido. Dito de outra forma, a legislação ordinária recebe da Constituição não só a sua legimitidade mas também, em larga medida, a delimitação de seu significado e alcance.

O mesmo não se dirá relativamente à Constituição, pelo simples fato de não haver outra norma que lhe seja superior.

Karl Larenz adverte que não se justifica, em matéria de interpretação constitucional, a "desvalorização do critério da gênese histórica" 73

Mais enfaticamente, Luis Carlos Sáchica sustenta que em matéria constitucional deve-se dar preferência ao método "que atende à vontade do

${ }^{72}$ Ives Gandra da Silva Martins, parecer sobre Fundação de direito privado não instituída por lei texto disponível em http://bdjur.stj.gov.br, acessso em 11.10.10

${ }^{73}$ Metodologia da Ciência do Direito, cit., p. 514. 
constituinte", porque "cada constituição significa uma resposta a uma situação histórica concreta e sua validade deriva da decisão de solucionar crises, estabelecer compromissos, iniciar transformações requeridas pelas relações sociais e políticas desse momento". ${ }^{74}$

De fato, como veremos ao longo deste trabalho, é significativa a importância que empresta, não raras vezes, à intenção do constituinte - não necessariamente a intenção subjetiva, mas aquela que ficou registrada, objetivamente, nos chamados trabalhos preparatórios da Constituição (conjunto de propostas, emendas, justificativas, pareceres, debates em plenário).

Bem por isso, Marcelo Caetano enfatiza a importância do exame dos trabalhos parlamentares para o estudo do Direito Constitucional, nomeadamente os debates nas assembléias constituintes e particularmente de suas comissões internas, encarregadas de examinar as emendas apresentadas no plenário pelos constituintes. Aduz o mestre português que "os trabalhos destas Comissões constituem importantíssimos subsídios para a interpretação dos textos promulgados" ${ }^{75}$

\subsection{Os excessos da interpretação constitucional: o ativismo judicial}

A polêmica sobre o ativismo judicial começa com sua própria conceituação: enquanto seus partidários costumam defini-lo utilizando termos como "modernização", "preenchimento de lacunas”, "atualização do Direito", seus adversários recorrem a termos bem pouco amenos, chegando ao ponto de tachá-lo, sem rodeios, como pura e simples usurpação de atribuições cometidas aos outros poderes.

É curioso observar que os várias acepções do termo ativismo, conforme registram os dicionários, apontam para significações pouco compatíveis com

\footnotetext{
${ }^{74}$ Derecho Constitucional General, ed. Themis, Bogotá, 4a . ed., 1999, p. 48.

${ }^{75}$ Direito Constitucional, v. II, Forense, $2^{\text {a }}$. ed., 1987, p. 37 . No capítulo 4, veremos que diversos constitucionalistas brasileiros também realçaram a grande importância dos trabalhos preparatórios das assembléias constituintes.
} 
a imparcialidade e a isenção de ânimo imprescindíveis quando se trata de lidar com a distribuição de justiça.

O Dicionário Houaiss aponta os seguintes significados:

qualquer doutrina ou argumentação que privilegie a prática efetiva de transformação da realidade em detrimento da atividade exclusivamente especulativa, frequentemente subordinando sua concepção de verdade e de valor ao sucesso ou pelo menos à possibilidade de êxito na ação; (2) gênero de literatura com conteúdo político; literatura engajada; (3) propaganda a serviço de uma doutrina ideológica, partidária, sindical etc.; (4) trabalho desenvolvido especialmente em meios revolucionários, politicos, estudantis, sindicais etc.; militância.

O Michaelis chega a estabelecer relação entre ativismo e "uso da força para fins políticos”, enquanto o Aurélio também faz a conexão com a idéia de “militância política”.

Naturalmente, os partidários do ativismo judicial procuram enfatizar outros aspectos, tentando por de lado essas incômodas implicações semânticas.

Para Luis Roberto Barroso,

“ativismo judicial é uma postura filosófica, é uma atitude diante da interpretação constitucional, é uma forma de realizar a interpretação constitucional (...) a idéia de ativismo judicial está associada à intenção de concretização mais ampla possível dos valores e dos princípios constitucionais, mesmo que o legislador não tenha atuado, mesmo que o Executivo não tenha atuado"76.

Os defensores do ativismo judicial costumam dizer que, ao interpretar a Constituição e as leis, o Judiciário nada mais faz do que cumprir seu papel - mesmo que nesse processo interpretativo acabe por reconhecer ou criar regras não previstas expressamente pelo legislador. Mais que isso, consideram-no necessário

\footnotetext{
${ }^{76}$ Ingerência constitucional do Judiciário na vida política brasileira: o ativismo judiciário, a judicialização da política e o novo enfoque do mandado de injunção (Anais da VI Conferência dos Advogados do Distrito Federal, 2008, pp. 88-97.
} 
para superar omissões dos outros Poderes. Essa é, por exemplo, a posição do decano do nosso STF:

"Práticas de ativismo judicial, embora moderadamente desempenhadas por esta Corte em momentos excepcionais, tornam-se uma necessidade institucional, quando os órgãos do Poder Público se omitem ou retardam, excessivamente, o cumprimento de obrigações a que estão sujeitos por expressa determinação do próprio estatuto constitucional, ainda mais se se tiver presente que o Poder Judiciário, tratando-se de comportamentos estatais ofensivos à Constituição, não pode se reduzir a uma posição de pura passividade.",77

A expressão "ativismo judicial" foi pela primeira vez utilizada por Arthur Schlesinger, em 1947, num artigo sobre a Suprema Corte norteamericana. Segundo o Black's Law Dictionary, trata-se de “uma filosofia quanto à decisão judicial mediante a qual os juízes permitem suas decisões sejam guiadas por suas opiniões pessoais sobre políticas públicas, entre outros fatores", acrescentando que o termo usualmente sugere que essa filosofia costuma ignorar os precedentes e tende à prática de violações à Constituição. Situa-se em exata contraposição ao conceito de auto-contenção judicial (judicial restraint), que o mesmo dicionário define como a filosofia pela qual os juízes evitam levar em conta suas próprias opiniões e crenças, procurando apenas interpretar a lei tal como ela foi feita, e de acordo com os precedentes.

O Juiz Antonin Scalia, da Suprema Corte dos Estados Unidos, em vários de seus votos qualificou o ativismo judicial como simples usurpação de poderes da legislatura ou de autoridades administrativas ${ }^{78}$.

No Brasil, vai na mesma linha Elival da Silva Ramos, que em recente estudo monográfico definiu o ativismo judicial como "o desrespeito aos limites normativos substanciais da função jurisdicional, ${ }^{, 79}$.

\footnotetext{
${ }^{77}$ Discurso do min. Celso de Mello na posse do min. Gilmar Mendes na presidência do STF, 23.4.2008; disponível em www.stf.jus.br e em www.conjur.com.br .

${ }^{78}$ Voto proferido no caso Romer v. Evans, em 1996.
} 
Em trabalho publicado originalmente em 1993, analisando os horizontes delineados pela vigente Constituição brasileira, Manoel Gonçalves Ferreira Filho já alertava para os riscos da judicialização de questões políticas, com a inevitável contrapartida de uma indesejável politização do Poder Judiciário. ${ }^{80}$

Luis Carlos Sáchica, sem se referir expressamente ao ativismo, mas descrevendo o mesmo tipo de postura, adverte contra os perigos de uma escola interpretativa

"que pensa que cada geração tem direito a seu próprio direito e, portanto, a atualizar as normas da ordem jurídica, reinterpretando-as para atualizá-las. Como se no juiz de hoje estivesse redivivo o constituinte de ontem, para adotar uma fórmula acorde com o presente. (...) Perigosamente essa tendência proclama a idéia de que o juiz deve fazer justiça, introduzindo um fato político - ideológico e subjetivo - na interpretação, em especial quando se qualifica a justiça, dizendo-a social (....) convertendo a norma em uma mera referência para apoiar o conceito de justiça que o juiz quer implantar ${ }^{81}$.

Isso acaba por equiparar o juiz ao próprio constituinte,

atribuindo-lhe

"uma competência que não está condicionada nem pelos antecedentes da Constituição - o processo histórico, a força do passado, a tradição - nem pela letra em que vertida a decisão constituinte, rastro de uma vontade política inicial, criadora - o princípio gerador de autoridade e legitimidade - e tampouco pela lógica interna da ordem jurídica como um todo (...)

Um poder assim, quase inteiramente fático, é um poder originário, fundador, constituinte.”

\footnotetext{
${ }^{79}$ Ativismo Judicial - Parâmetros Dogmáticos, Saraiva, 2010, pg. 138.

${ }^{80}$ Poder Judiciário na Constituição de 1988 - Judicialização da política e politização da Justiça. In Aspectos do Direito Constitucional Contemporâneo, Saraiva, 2003, pp. 189-216.

${ }^{81}$ Derecho Constitucional General, cit., p. 49.
} 
Luis Sáchica conclui que essa concepção não se harmoniza com o próprio Estado de Direito, no qual o Poder Judiciário é, tal como os demais, constituído, limitado pela própria Constituição, com uma função

"moderadora dos outros poderes - porém, nada mais. Sua função é negativa. É um poder que impede que se faça ou corrige o que foi feito. Mas não pode suplantar ao constituinte para formular decisões com poder normativo permanente, como força igual à da Constituição" ${ }^{\prime 2}$.

No Brasil, essa mesma percepção vem sendo realçada, especialmente após 2003, quando o Supremo Tribunal Federal passou a adotar uma postura mais acentuadamente ativista.

Nesse sentido, Alexandre de Moraes aponta o "fortalecimento do ativismo judicial", com uma "concentração excessiva de poder no próprio Supremo Tribunal", reforçada, entre outros meios, pelo emprego das súmulas vinculantes e da atribuição de efeitos erga omnes a decisões tomadas em sede de controle difuso de constitucionalidade, o que torna imperiosa a necessidade de discutir os limites do ativismo judicial. $^{83}$

Elival da Silva Ramos faz crítica semelhante. Para ele, "há disfunção na atividade do STF, que quer legislar sobre determinadas matérias”, o que é "absolutamente negativo": "A corte tem ultrapassado os limites do texto constitucional para criar novas soluções e, com isso, a competência do legislador fica usurpada” ${ }^{84}$.

\footnotetext{
${ }^{82}$ Ob. cit., p. 50.

${ }^{83}$ A tendência moderna de imbricação entre o controle difuso e o controle concentrado no âmbito do Supremo Tribunal Federal - Anais da Conferência dos Advogados do DF, 2008, pp. 76-84.

${ }^{84}$ Entrevista ao sítio Consultor Jurídico, ed. 1.8.2009, disponível em www.conjur.com.br.
} 
O próprio Canotilho, conhecido por suas posições de vanguarda, afirmou que o Supremo Tribunal brasileiro vem praticando um "ativismo judicial exagerado, que não é compreendido na Europa", avançando cada vez mais em assuntos que são da alçada dos Poderes Legislativo e Executivo (um dos exemplos que cita é, precisamente, a criação de normas constitucionais por meio de súmulas vinculantes). O festejado constitucionalista afirma que o STF está criando novas normas constitucionais (por exemplo, por meio das súmulas vinculantes) e definindo políticas públicas (como no caso da demarcação de terras indígenas), o que não faz sentido para o constitucionalismo europeu. ${ }^{85}$

A preocupação com os excessos do ativismo, como veremos no capitulo seguinte, foi a principal causa para o surgimento do movimento originalista nos Estados Unidos.

\footnotetext{
${ }^{85} \mathrm{O}$ termo utilizado por Canotilho foi "nonsense". Na mesma entrevista, esse autor também ironiza a idéia de "cada geração poderia fazer a Constituição que quiser", pois quem acaba fazendo essa "nova" Constituição é a elite, não o povo (STF tem ativismo sem paralelo, diz jurista -entrevista concedida ao jornalista Juliano Basile, jornal Valor Econômico, ed. 4.11.2009).
} 


\section{CAPÍTULO 2 - O MOVIMENTO ORIGINALISTA NOS ESTADOS UNIDOS}

\subsection{Conceito e contextualização do originalismo}

Nos Estados Unidos, a interpretação constitucional assume importância singular, devido ao caráter extremamente conciso da Constituição, sua permanência ao longo de mais de dois séculos e processo extremamente dificultoso para emendá-la ${ }^{86}$

As numerosas escolas e tendências interpretativas no direito constitucional norte-americano podem ser divididas, basicamente, em dois grandes grupos: o interpretativista e o não-interpretativista.

O interpretativismo, consiste, na definição de John Hart Ely, como o ponto de vista segundo o qual "os juízes, ao decidir sobre matéria constitucional, devem ater-se a dar cumprimento às normas que estão previstas ou claramente implícitas na Constituição". ${ }^{87}$

O interpretativismo ampara-se na busca de princípios neutros aqueles originalmente previstos pelos Fundadores, de modo a evitar interpretações discricionárias, de acordo com as preferências subjetivas de cada um. A inobservância destes postulados faz com que o judiciário invada competências reservadas aos poderes democraticamente eleitos, violando a soberania popular. ${ }^{88}$

\footnotetext{
${ }^{86} \mathrm{O}$ art. V da Constituição prevê que ela somente será emendada se a proposta for aprovada por dois terços do Senado e da Câmara, e ratificada por pelo menos três quartos dos Estados.

${ }^{87}$ Democracy and Distrust, 1980, p. 1.

${ }^{88}$ Néstor Sagüés, La Interpretación Judicial de la Constitución, p. 74.
} 
$\mathrm{O}$ originalismo vai um pouco além, sustentando que as normas constitucionais devem ser observadas tal como eram "entendidas por aqueles que as escreveram e ratificaram". 89

O não-interpretativismo, por sua vez, admite que os juízes podem ir além do que está na Constituição, podendo se falar na posição não-originalista como a que aceita a aplicação das normas constitucionais interpretadas livremente, sem nenhuma preocupação com o entendimento vigente ao tempo em que editadas. ${ }^{90}$

A idéia central do originalismo consiste em reconhecer que o propósito de uma Constituição escrita é fixar normas para viger indefinidamente, a menos que sejam modificadas pelo procedimento que ela própria contempla (ou seja, por via de emenda). Como diz Goldford, o postulado principal do originalismo é a fixidez do sentido das disposições constitucionais: o entendimento original é dotado de autoridade vinculante; a interpretação das normas é necessária, mas não pode distorcer ou modificar esse sentido original. ${ }^{91}$

O originalismo não é, portanto, um novo método de intepretação constitucional, mas uma variante peculiar do método histórico (v. capítulo anterior), adaptados às condições peculiares da evolução constitucional norteamericana.

Por isso, preferimos falar em enfoque ou técnica originalista, atentos à distinção de Linares Quintana, anteriormente apontada.

\subsection{O originalismo como reação ao ativismo}

A exacerbação de posturas não-interpretativistas, no século XX, levou ao fenômeno do ativismo judicial, sobre o qual já tecemos algumas considerações no primeiro capítulo.

\footnotetext{
${ }^{89}$ Dennis Goldford, The American Constitution and the Debate over Originalism, 2005, p. 96.

${ }^{90}$ Goldford, ob. cit., p. 96.

${ }^{91}$ Ob. cit., p. 91.
} 
No contexto norteamericano, a primeira decisão considerada como ativista - embora o termo não fosse empregado na época - foi proferida no célebre caso Dred Scott, de 1857. Julgando uma lei uma lei que libertava automaticamente os escravos que ingressassem num território onde a escravidão tivesse sido anteriormente abolida, a Suprema Corte declarou-a inconstitucional, por ferir o direito de propriedade, protegido pela cláusula do due process of law. Esta decisão, por sinal, foi um dos fatores que precipitaram a eclosão da Guerra Civil.

A cláusula do devido processo legal também foi invocada na decisão Lochner v. New York, de 1905, invalidando lei que limitava a jornada de trabalho dos padeiros a dez horas diárias; o argumento foi de que a lei privava os cidadãos de sua liberdade de contratar.

As duas decisões citadas são suficientes para demonstrar a absoluta impropriedade da associação, que por vezes se faz, entre ativismo e idéias progressistas. O ativismo pode, perfeitamente, assumir um caráter conservador, restringindo a conquista de direitos sociais.

Essa decisão foi tão emblemática que a expressão Era Lochner passou a ser utilizada para referir-se a ao período em que a Suprema Corte "passou a tomar decisões que substituíam a vontade do legislador". ${ }^{92}$

O ativismo ganhou extraordinário relevo com a Corte Warren, especialmente a partir da decisão Brown v. Board of Education, de 1954, em que foi declarada inconstitucional uma lei que adotava o critério "iguais, mas separados" (ou seja, permitindo instalações públicas diferentes para negros e brancos, desde que teoricamente - fossem de igual qualidade). Assim decidindo, a Suprema Corte derrubou um precedente dela própria, em que se afirmava exatamente o contrário (Plessy v. Ferguson, de 1896), e dessa forma pôs fim à segregação racial.

Outras decisões clássicas do ativismo judicial foram: o reconhecimento do direito constitucional à privacidade (Griswold v. Connecticut, de 1965), a necessidade de que toda pessoa presa em flagrante ser alertada sobre seus direitos constitucionais (Miranda v. Arizona, 1966), e o mais controvertido de todos, o

${ }^{92}$ Oscar Vilhena Vieira, Supremocracia, Revista Direito GV, jul./dez. 2008. 
reconhecimento do direito constitucional ao aborto, como projeção do direito à privacidade (caso Roe v. Wade, 1973).

Vê-se que há decisões ativistas claramente alinhadas com o pensamento dito "progressista" (direito à privacidade, aborto), enquanto outras alinham-se com o mais radical conservadorismo (Dred Scott, Lochner).

Grande parte dos juristas norte-americanos enxergam perigos no ativismo judicial, que pode conduzir a um "governo dos juízes”, justamente num país que tanto preza a vontade popular como fonte do poder. ${ }^{93}$

Veja-se, nesse sentido, a posição de Ronald Dworkin - que certamente não se inclui entre os juristas conservadores:

"O ativismo é uma forma virulenta de pragmatismo jurídico. Um juiz ativista ignoraria o texto da Constituição, a história de sua promulgação, as decisões anteriores da Suprema Corte que buscaram interpretá-la e as duradouras tradições de nossa cultura política. O ativista ignoraria tudo isso para impor a outros poderes do Estado o seu próprio ponto de vista sobre o que a justiça exige." (O Império do Direito, p. 451).

Robert Levy e William Mellor selecionaram doze julgamentos da Suprema Corte, proferidos entre 1934 e 2005, que expandiram significativamente os poderes governamentais, segundo eles em desacordo com o texto da Constituição e os propósitos dos Pais Fundadores; trata-se de decisões ativistas que, muitas vezes tomadas por estreita maioria, redesenharam totalmente conceitos substanciais da Constituição, relativamente ao federalismo, direitos civis, direito de propriedade, liberdade de expressão, liberdade de contratar e outros assuntos de magna importância. $^{94}$

As severas críticas dirigidas ao ativismo ensejaram, da parte de juízes e doutrinadores, o desenvolvimento de técnicas de interpretação capazes de

${ }^{93}$ Nesse sentido, Raoul Berger, Government by Judiciary, originalmente publicado em 1977 (2a. ed., Liberty Fund, 1997).

${ }^{94}$ R. Levy e W. Mellor, The Dirty Dozen, Cato Institute, 2008. 
viabilizar o judicial restraint, ou auto-contenção judicial, de modo a preservar a separação de poderes e a legitimidade democrática dos legisladores.

Uma delas é a chamada teoria das “questões políticas", pela qual o Judiciário deve abster-se de adentrar às questões dessa natureza, que devem ser deixadas para decisão dos poderes eleitos.

Outra é o chamado "minimalismo", defendido por Cass Sunstein, segundo o qual os juízes devem interferir minimamente na ordem constitucional, atendo-se apenas à solução dos casos concretamente apresentados a julgamento, apegando-se aos precedentes e à doutrina do stare decisis.

Mas é certo que, dentre as técnicas de auto-contenção, a que alcançou mais alta repercussão foi o originalismo.

Os originalistas sustentam que é preciso fazer uma escolha entre "ser governado por juízes, de acordo com suas próprias inclinações, ou ser governado pelo povo"; os juízes somente serão guardiões da liberdade do povo se interpretarem a Constituição segundo o entendimento original com que esta foi promulgada, refletindo a vontade constituinte do povo soberano. ${ }^{95}$

\subsection{Evolução do originalismo}

Como movimento ou escola interpretativa, o originalismo surgiu reativamente, como resposta ao ativismo da Suprema Corte nas décadas de 60 e 70 (Cortes Warren e Burger).

Mas a idéia de respeito ao chamado ao entendimento original tem profundas raízes no sistema jurídico norteamericano.

${ }^{95}$ R. Bork, The Tempting of America, p. 160. 
Já no Federalista n. 78, Alexander Hamilton afirmava que os juízes não poderiam interpretar a Constitução substuindo "as intenções constitucionais (...) por seus próprios desejos", e que o sentido da Constituição deveria vigorar "até que o povo tenha, por um ato solene e oficial, anulado ou mudado a forma estabelecida". ${ }^{96}$

O juiz da Suprema Corte Joseph Story, em 1833, afirmava que tem um significado "fixo e uniforme (...) independente das opiniões e paixões de cada época; é o mesmo ontem, hoje e sempre". ${ }^{97}$

Como assinala Howard Gillman, nos séculos XVIII e XIX havia praticamente um consenso nas cortes e também entre os tratadistas no sentido de que “os juízes eram obrigados a interpretar a Constituição segundo o entendimento original de seus dispositivos" 98

No início do século XX, ao julgar o caso South Carolina v. United States (1905), a Suprema Corte proclamou: “A Constituição é um documento escrito. De tal modo, seu sentido não se altera. O que significava quando adotada, é o que significa atualmente." 99

O originalismo ganhou força no meio acadêmico a partir da década de 1970, com a poublicação dos trabalhos de Robert Bork ${ }^{100}$ e Raoul Berger ${ }^{101}$, além da nomeação de William Rehnquist para a Suprema Corte. Na década seguinte, a tendência foi reforçada no mais alto Tribunal, com a elevação de Rehnquist a Chief Justice e a concomitante nomeação de Antonin Scalia (ambas em 1986). Em 1987 houve a frustrada tentativa de nomeação de Robert Bork, sendo a vaga a final ocupada por Anthony Kennedy, um conservador moderado que eventualmente se alinha as idéias originalistas. Com a nomeação do juiz Clarence Thomas em 1991 e de Samuel Alito em 2006, bem como a substituição de Renhquist por John Roberts, em 2005, a

\footnotetext{
${ }^{96}$ Os Artigos Federalistas, ed.Nova Fronteira, 1987.

97 Joseph Story, Commentaries on the Constitution of the United States, § 426 . Em várias outras passagens, a mesma idéia é enfatizada, sempre com base no argumento de que a autoridade da Constituição deriva diretamente da soberania do povo.

${ }^{98}$ Howard Gillman , The Collapse ?

${ }^{99}$ Esse trecho, extraído do voto do juiz David Brewer, em nome da Corte, é hoje considerado como precursor do originalismo - v. Dennis Goldford, The American Constitution...., cit., p. 93.

${ }^{100}$ Neutral Principles and some First Amendment Problems, 1971.

${ }^{101}$ Government by Judiciary, de 1977.
} 
Suprema Corte passou quatro membros partidários do originalismo (Roberts, Scalia, Thomas e Alito), além da adesão eventual do quinto e decisivo voto (Kennedy).

Esses cinco juízes formaram a maioria no caso District of Columbia v. Heller, em 2008, quando pela primeira vez a Suprema Corte adotou, franca e inequivocamente a interpretação originalista ${ }^{102}$, ao interpretar a Segunda Emenda segundo seu sentido original, de modo a reconhecer o direito de cada cidadão a portar armas. No texto dessa decisão, redigida pelo juiz Scalia, afirma-se que a Constituição "foi escrita para ser entendida pelos eleitores; suas palavras e frases foram usadas em seu sentido normal e ordinário, distinto do sentido técnico".

Esse julgamento é qualificado por Jeffrey Shaman como "o apogeu do originalismo". ${ }^{103}$

Como assinala Earl Maltz, em elegante síntese:

"A despeito de repetidos anúncios da morte do originalismo, por parte de seus oponentes, ele continua a desempenhar um papel central no debate sobre a própria estrutura do direito constitucional. Originalistas como Raoul Berger e Robert H. Bork permanecem, sob qualquer parâmetro, como vozes principais no debate. Além disso, o originalismo é também um fator importante na maioria das teorias não-originalistas, uma vez que seus adeptos começam, tipicamente, com a recitação do que consideram defeitos da jurisprudência baseada no entendimento original. $\mathrm{O}$ originalismo também fornece uma linha de base conveniente, pela qual outras abordagens podem ser avaliadas. Finalmente, muitos daqueles que rejeitam uma estrita dependência ao entendimento original mantêm elementos originalistas como parte de seu estrutura geral."

\footnotetext{
${ }^{102}$ Nesse sentido, Lawrence Solum: "A teoria de interpretação constitucional [adotada] em Heller é originalista" (Semantic Originalism, p. 3).

${ }^{103}$ The End of Originalism, 2009, nota 15.

${ }^{104}$ Earl M. Maltz, Rethinking Constitutional Law: originalism, interventionism, and the politics of judicial review, p. 15.
} 


\subsection{A indicação de Robert Bork para a Suprema Corte}

A indicação do juiz Robert Bork para uma vaga na Suprema Corte, feita em julho de 1987 pelo presidente Reagan, desencadeou um ensejou um debate sobre questões constitucionais de proporções inéditas. O país inteiro acompanhou pela televisão, em setembro, quatro dias de intensos debates no Senado, abordando algumas das mais importantes e difíceis questões do constitucionalismo norteamericano, em termos altamente técnicos, que a maioria da população dificilmente poderia compreender. Separação dos poderes, valor dos precedentes, legitimidade do judicial review, declaração de direitos, privacidade, aborto, pena de morte, proibição de penas cruéis, a cláusula de igual proteção: tudo foi alvo de perguntas bem elaboradas pelos Senadores, respondidas no mesmo nível pelo candidato, um experiente professor de Direito Constitucional e juiz de uma das mais importantes cortes federais. Até observadores estrangeiros ficaram impressionados com o nível dos debates e o interesse que eles despertaram na opinião pública. ${ }^{105}$

O originalismo esteve desde o início no centro dessa polêmica, uma vez que Bork era então considerado um de seus mais destacados expoentes (posição que conserva até hoje). Em livro publicado dezoito anos depois, contendo a transcrição daquelas audiências, o capítulo reservado aos questionamentos sobre o "original intent" ocupa quarenta e três páginas, mais do que qualquer outro tema abordado. $^{106}$

Talvez por isso, o fato de ter sido a final recusada a indicação é associado, por prestigiosos autores nacionais, com a idéia de uma rejeição do próprio originalismo. $^{107}$

\footnotetext{
${ }^{105}$ Toda a controvérsia então gerada foi minuciosamente analisada por Ethan Bronner em Battle for Justice - how the Bork nominations shook America (New York, 1989), e resumida de modo excelente por Miguel Beltrán de Felipe, Originalismo e Intepretación, Madri, 1989, pp. 25-35.

${ }^{106}$ The Bork Hearings, ed. Ralph Shaffer, Princeton, 2005.

${ }^{107}$ Luis Roberto Barroso, Intepretação e Aplicação da Constituição, Saraiva, $7^{\mathrm{a}}$.ed., 2009, p. 119; Eros Roberto Grau, Ensaio e Discurso sobre a Interpretação/Aplicação do Direito, Malheiros, 2002, p. 110.
} 
Essa conclusão é extremamente simplificadora. Em primeiro lugar, é preciso observar que Robert Bork era um expoente do originalismo desde, pelo menos, 1971, quando publicou um importante e influente artigo sobre Princípios neutros e alguns problemas da Primeira Emenda. ${ }^{108}$ E, nessa condição, o Senado americano aprovou seu nome em 1981, sem nenhuma ressalva, para o cargo juiz do Tribunal Federal do Distrito de Columbia, o mais importante dos tribunais de segunda instância do país.

Em terceiro lugar, William Renhquist apresentou-se como um candidato partidário do originalismo em 1971, quando aprovado para a Suprema Corte, e assim também em 1986, quando foi elevado à posição de Chief Justice.

Ainda em 1986 - portanto, apenas um ano antes da indicação de Robert Bork - outro destacado originalista, Antonin Scalia, foi aprovado por unanimidade para uma cadeira na Suprema Corte. Até essa data, por sinal, Scalia e Bork judicavam no mesmo tribunal, e seus votos eram quase sempre concordantes.

Finalmente, a leitura das transcrições das audiências de confirmação de Bork mostra que a oposição dos senadores deveu-se não à filosofia originalista - mesmo porque esta prestigia a decisão política do legislador - mas sim ao radicalismo do candidato em relação ao reconhecimento do direito constitucional à privacidade e à sua falta de habilidade política, respondendo em termos estritamente acadêmicos, e com excessiva franqueza ${ }^{109}$, a todos os questionamentos formulados.

Um outro componente que muito pesou para a rejeição foi a sistemática distorção das opiniões lançadas pelo candidato, que foi apresentado à opinião pública como obscurantista, medieval, "inimigo" das mulheres e dos negros,

\footnotetext{
${ }^{108}$ Neutral Principles and some First Amendment Problems, Indiana Law Journal, v. 47; o texto deste artigo também consta de A Time to Speak, compilação dos melhores trabalhos acadêmicos, votos e arrazoados forenses de Robert Bork (ISI Books, 2008, pp. 186-219).

${ }^{109}$ Esse ponto é bem ressaltado por Beltrán de Felipe (ob. cit., p. 31), e admitido inclusive por Ronald Dworkin, opositor da indicação (artigo publicado em 13.8.1987 no New York Times, citado por Beltrán de Felipe). É fato notório que em todas as posteriores sabatinas para a Suprema Corte os candidatos sistematicamente esquivaram-se de responder às questões mais polêmicas, sob o argumento de que não podiam adiantar opinições sobre assuntos que poderiam vir a ser objeto de julgamentos futuros. retexto de não gerarem nenhum tipo de suspeição para julgamentos futuros. Esse foi um dos efeitos mais significativos do trauma gerado pela rejeição de Bork.
} 
entre outras colocações inteiramente inapropriadas. ${ }^{110}$ A disseminação de grosseiras generalizações muito pesou na decisão dos senadores, pressionados por amplos setores de seu eleitorado. ${ }^{111}$

É de se observar, ainda, que posteriores indicações de simpatizantes do originalismo para a Suprema Corte - Clarence Thomas, em 1991; John Roberts, em 2005; Samuel Alito, em 2006 - foram aprovadas pelo Senado, o que bem demonstra que a impropriedade de se apresentar a rejeição de Bork como uma derrota do originalismo.

\subsection{Principais críticas ao originalismo}

Como dissemos na introdução, o originalismo ocupa lugar absolutamente central nas discussões sobre interpretação constitucional nos Estados Unidos. É imensa a produção intelectual a respeito ${ }^{112}$, e sua análise exaustiva não é o objetivo deste trabalho.

\footnotetext{
${ }^{110}$ Nos seus sete anos de judicatura federal, nenhum voto do juiz Bork foi motivo de celeuma ou censura pública, mesmo de parte de movimentos organizados de minorias.

${ }^{111}$ Na ocasião, a Comissão de Justiça do Senado era presidida por um pré-candidato à Presidência dos Estados Unidos, Joseph Biden (trata-se, por sinal, do atual vice-presidente). E o decano da Comissão, Senador Edward Kennedy, enfrentava um difícil momento em sua carreira política; não por acaso, desde o início se opôs asperamente à indicação de Bork. A natureza estritamente política da rejeição, apresentada como um trunfo dos democratas perante seu eleitorado, ficou bem caracterizada em diálogo mantido pelo Presidente Reagan com o Senador DeConcini, um dos líderes daquele partido: após mencionar que Bork tinha importantes apoios na sociedade e no meio acadêmico, além de ser "verdadeiramente qualificado" para o cargo, o Presidente ponderou que "a política devia ficar fora disso", ao que o Senador respondeu: "A política tem de entrar nisso" (Bronner, Battle for Justice, cit., p. 312).

${ }^{112}$ Para mencionar apenas alguns dos mais importantes estudos a respeito do originalismo, podemos citar os seguintes: Miguel Beltrán de Felipe, Originalismo e Interpretación, Madri, 1989; Robert Bork, The Tempting of America,1991; Gregory Bassham, Original Intent and the Constitution, 1992; Antonin Scalia, A Matter of Interpretation, Princeton, 1997; Keith Whittington, Constitutional Interpretation: textual meaning, original intent \& judicial review, 1999; Randy Barnett, Restoring the Lost Constitution, Princeton University Press, 2004; Dennis Goldford, The American Constitution and the Debate over Originalism, Cambridge, 2005; Johnathan O`Neill, Originalism in American Law and Politics - A Constitutional Story, Baltimore, 2005; Steven Calabresi (ed.), Originalism - a QuarterCentury of Debate, Washington, 2007.
} 
No entanto, uma breve referência às principais objeções levantadas contra as concepções originalistas é não somente útil, mas necessária para melhor compreensão dos tópicos dos capítulos seguintes.

A primeira e mais comum crítica que se faz ao originalismo diz respeito à extrema dificuldade, senão a real impossibilidade, de se conhecer as verdadeiras intenções do constituinte. ${ }^{113}$

A censura, porém, está deslocada, porque dirigida a uma das primeiras formulações do originalismo, que atribuía valor decisivo apenas à intenção original dos constituintes, esquecendo o desenvolvimento posterior, que caminhou para o conceito de entendimento original. E este somente será relevante se for discernível, isto é, passível de ser conhecido por meio dos registros históricos disponíveis. Nos capítulos finais, veremos que até mesmo em nosso país é muitas vezes possível remontar a essa intenção; nos Estados Unidos, em que há uma vastíssima literatura sobre o processo de elaboração ${ }^{114}$ e ratificação ${ }^{115}$ da Constituição, a crítica parece ainda menos relevante.

Cabível levar em consideração as palavras de Robert Bork (ainda que se referindo à descoberta do entendimento original): nenhuma pesquisa ou investigação dessa natureza pode almejar a um resultado perfeito; basta trabalhar com o melhor que tivermos à disposição, e isto normalmente será suficiente. ${ }^{116}$

Em estreita conexão com o argumento anterior, está a acusação de que o originalismo remeteria a um ultrapassado subjetivismo, retrocedendo da mens legis para a mens legislatoris.

\footnotetext{
${ }^{113}$ A objeção é feita, por exemplo, por Beltrán de Felipe (Originalismo y Interpretación, p.70), e Alonso García (Interpretación de la Constitución, pp. 138-142).

114 Existe abundante material para a pesquisa dos debates da Convenção de Filadélfia e dos entendimentos jurídicos dos Pais Fundadores. Podemos citar, apenas a título de exemplo, os cinco alentados volumes da obra The Founders' Constitution, editados por P. Kurland e R. Lerner,Liberty Fund, 1987, bem como The Heritage Guide for the Constitution (Meese, Spalding e Forte, The Heritage Foundation, 2005), e The Authentic Constitution - An Originalist View of America's Legacy (A. Palumbo, Algora Publishing, 2009).

${ }^{115}$ V. Pauline Maier, Ratification - The People Debate the Constitution, 1787-1788, Simon \& Schuster, 2010.

${ }^{116}$ The Tempting of America, 1991, p. 163.
} 
Já antecipamos uma resposta a essa crítica no primeiro capítulo, ao sustentar que, em matéria constitucional, a "vontade do constituinte" tem uma relevância muito maior do que a "vontade do legislador" em matéria de legislação ordinária. Nem se trata de conferir autoridade vinculante a uma inescrutável subjetividade do constituinte, mas sim à "intenção" objetivada, registrada claramente no processo de formação da norma constitucional. Nesse sentido, aliás, têm caminhado as formulações atuais do originalismo, que põem de lado a idéia da original intent e passam a trabalhar com o conceito de original understanding.

Outra crítica comumente levantada é no sentido de que o originalismo levaria à estagnação ou petrificação do direito constitucional, contrapondo-o à idéia da living Constitution. ${ }^{117}$. A Constituição deve ser constamente adaptada às mudanças da sociedade, não devendo sua interpretação ficar vinculada ao significado de suas cláusulas no momento da promulgação.

A objeção é assim refutada por Robert Bork:

“A filosofia do entendimento original não produz uma constituição rígida ou uma jurisprudência mecânica. Pelo contrário, ela controla o processo de desenvolvimento da doutrina constitucional num modo que preserva a relevância e integridade da Constituição. (...) É tarefa dos juízes da atual geração discernir como os valores dos Fundadores, definidos no contexto do mundo que eles conheceram, aplicam-se ao mundo que nós conhecemos".

E Bork oferece vários exemplos que deixam muito clara essa postura:

“A Quarta Emenda, que proíbe buscas e apreensões arbitrárias, foi formulado por homens que não poderiam prever o surgimento da vigilância eletrônica. Nem por isso se equivocam os juízes que aplicam o valor central dessa emenda a casos de invasão eletrônica da privacidade. O poder do Congresso de

${ }^{117}$ Beltrán de Felipe, ob. cit., p. 59. 
regular o comércio foi estabelecido por homens que não previam o alcance, tecnologias e intrincada interdependência da economia atual. Mas isso não impede os juízes de proibir aos Estados a regulação excessivamente onerosa do transporte interestadual. A garantia de liberdade de imprensa pela Primeira Emenda foi escrita por homens que não tinham a mais remota idéia das modernas formas de comunicação. Mas não erra um juiz que considera relevantes os valores da Primeira Emenda para as transmissões de rádio e televisão". ${ }^{118}$

De fato, essa crítica deixa de levar em conta a diferenciação entre o núcleo essencial de um conceito e sua possível (aliás, necessária) aplicação a situações não originalmente previstas, seja por analogia, seja por interpretação extensiva. As ciências da linguagem estabelecem clara diferença entre o signo (ou enunciado) e o referente, definindo este como "o objeto do mundo" designado pelo primeiro. ${ }^{119}$ Como veremos no próximo capítulo, a Suprema Corte da Austrália chega ao mesmo resultado, utilizando outros termos (conotação e denotação), diferenciando claramente o cerne ou núcleo de um conceito (que não pode ser mudado ao sabor das preferências do intérprete), e sua aplicação a situações novas, que não importam a descaracterização daquele núcleo essencial. ${ }^{120}$

Mesmo constituições muito mais novas do que a norteamericana exigem essa atualização de conceitos. Quando o constituinte brasileiro de 1988 estabeleceu a vedação à cobrança de impostos sobre "livros, jornais e periódicos" (art.

\footnotetext{
${ }^{118}$ Bork,The Tempting of America, cit., pp. 167-168.

${ }^{119}$ Franck Neveu, Dicionário de Ciências da Linguagem, Vozes, 2007, p. 58, verbete referência. A função referencial é por vezes denominada denotação (Ducrot e Todorov, Dicionário Enciclopédico das Ciências da Linguagem, ed. Perspectiva, 1988, p. 103).

${ }^{120}$ Com a devida vênia, parece-nos que o professor e ex-ministro Eros Grau incide nesse equívoco, ao invocar contra o originalismo o argumento relativo à aplicação atual do artigo do Código Penal que tipifica o ato obsceno (Ensaio e Discurso sobre a Interpretação/Aplicação do Direito, cit., p. 110). É certo que esse dispositivo não incide hoje sobre atos ou comportamentos que o legislador de 1940 consideraria patentemente escandalosos ou mesmo imorais, mas não tem esse significado na sociedade atual. A alteração dos padrões culturais - inevitável, após o transcurso de sete décadas - não é incompatível com o respeito ao entendimento original do texto: o comportamento eivado de obscenidade deve ser punido criminalmente, seja em 1940, seja em 2011; a mudança do "referente" (ou seja, dos comportamentos ofensivos à moral pública) não invalida o núcleo central do conceito, que continua em vigor.
} 
150, VI, “d”), não podia nem sequer imaginar o surgimento da versão eletrônica dessas publicações; como também, ao estabelecer o sigilo da correspondência (art. $5^{\circ}$, XII), não previa que daí a poucos anos teríamos o "correio eletrônico". Ao estender a essas situações não previstas os mencionados dispositivos constitucionais, o intérprete não estará legislando ou criando novos direitos: estará apenas cumprindo a Constituição. ${ }^{121}$

Talvez o mais famoso e repetido argumento contra o originalismo é o de que levaria ao governo "dos mortos sobre os vivos" (muitas vezes referido, tomando por empréstimo uma expressão de Thomas Jefferson, como a questão da Dead Hand).

Randy Barnett, um originalista moderado, disse que por muito tempo considerou essa objeção bastante persuasiva, mas chegou à conclusão que ela não invalidava o originalismo: em primeiro lugar, porque as restrições da Constituição aplicam-se muito mais aos governantes do que aos cidadãos, exatamente para garantir a liberdade destes; em segundo lugar, a Constituição foi feita para evitar a injustiça e a opressão, não sendo meramente o produto da vitória de uma facção ou grupo; preservar ao máximo um documento que tem esses propósitos é uma justificativa que soa razoável para qualquer geração. ${ }^{122}$

Robert Bork é bem mais irônico: porque nos deixamos governar por um sistema republicano e presidencialista, por um judiciário independente, por um Congresso eleito, se essas foram decisões tomadas por homens que já morreram há muito tempo? Ademais, eles não nos proibiram, diz ele, de acrescentar novos direitos à nossa Cosntituição, nem de modificá-la. A questão, segundo ele, é na verdade um disfarce: sob a capa de oposição ao suposto governo por uma geração já falecida, quer-se na verdade impugnar o governo pela maioria dos viventes (living majorities), possibilitando a modificação da Constituição por juízes não-eleitos, portanto não investidos do poder de emendá-la. ${ }^{123}$

\footnotetext{
${ }^{121}$ Hoje ninguém levaria a sério o argumento do Chief Justice William Taft, no caso Olmstead v. United States, de 1928, recusando estender a proteção da Quarta Emenda contra "buscas arbitrárias" às escutas telefônicas, porque o telefone não existia quando promulgada a Emenda...

${ }^{122}$ Restoring the Lost Constitution, cit., p. 115-116.

${ }^{123}$ The Tempting of America, cit., pp. 170-171.
} 
Questão delicada para a teoria originalista é a possível contradição entre precedentes bem estabelecidos e o sentido original da Constituição.

Beltrán de Felipe menciona um julgamento emblemático, Dronemberg v. Zech, ocorrido no Tribunal Federal do Distrito de Columbia, em 1984, em que foi relator o próprio Juiz Bork. O apelante, Dque havia sido expulso da Marinha em razão de ser homossexual, pedia a anulação do ato, invocando o direito à privacidade, reconhecido pela Suprema Corte em Roe v. Wade, de 1973 (declarando a inconstitucionalidade de lei estadual proibindo o aborto). O Juiz Bork negou-se a aplicar o precedente invocado, por considerá-lo inconstitucional. ${ }^{124}$

O problema não está em discutir se Roe v. Wade foi uma decisão acertada (é até hoje altamente discutida), nem tampouco saber se a opinião de Bork é correta ou não (ela não constituiu nenhuma surpresa, pois como acadêmico já deixara muito claro seu ponto de vista). O problema está em que o respeito dos juízes aos precedentes de uma Corte superior é um princípio longamente estabelecido nos Estados Unidos, e não é difícil demonstrar que foi adotado originalmente pela Constituição. Compreensivelmente, Ronald Dworkin critica severamente a decisão de Bork no caso Dronemberg, considerando-a simplesmente ilegal; Beltrán de Felipe também considera inadmissível que um juiz norteamericano, desconsiderando o princípio do stare decisis, não siga a orientação emanada de uma Corte superior. ${ }^{125}$

Mas há uma questão teórica ainda mais relevante. Como resolver esse conflito em bases originalistas?

Em sua fala inicial perante a Comissão de Justiça do Senado, em 1987, Bork declarou que incumbia a um juiz respeitar "não apenas as intenções daqueles que fizeram de início a lei, mas também as dos juízes do passado, que interpretaram-na e aplicaram-na a casos anteriores". Na sequência, teve de responder a várias perguntas sobre o tema. Em síntese, admitiu que um precedente longamente estabelecido deveria prevalecer em face da intenção ou do entendimento original.

\footnotetext{
${ }^{124}$ Originalismo e Interpretación, cit., pp. 62-67. O caso é também comentado por Bronner, Battle for Justice, cit., pp. 189-190.

${ }^{125}$ Ob. cit., pp..66-67.
} 
Porém, de modo algo incoerente, não foi tão assertivo quanto à manutenção do direito à privacidade, "criado" pela Suprema Corte no caso Griswold v. Connecticut, de 1962 (portanto, vinte e cinco antes), nem tampouco em relação a Roe v. Wade. ${ }^{126}$

Em The Tempting of America, Bork ofereceu uma resposta bem mais elaborada, reafirmando o valor dos precedentes, que somente em casos extremos deveriam ser abandonados (overruled). Invertendo os termos da crítica, concluiu que o originalismo favorecia esse respeito aos precedentes, pois um juiz não-originalista, por não se julgar vinculado nem mesmo aos termos estritos da Constituição, com maior razão não se sentiria obrigado a seguir à risca os precedentes: "Se não há preocupação com estabilidade, se o resultado imediato é o único importante, não há motivo para respeitar nem o texto da Constituição nem as decisões de seus predecessores". ${ }^{27}$

\footnotetext{
${ }^{126}$ Ralf Shaffer, The Bork Hearings, cit., pp. 4 e 54-62; Bronner, Battle for Justice, cit., pp. 258-260.

${ }^{127}$ The Tempting of America, cit. pp. 155-159. A conclusão semelhante chega Lee Strang, An originalist theory of precedent: The Privileged Place of Originalist Precedent (disponível em http://works.bepress.com/lee_strang/2).
} 


\section{CAPÍTULO 3: INTERPRETAÇÃO ORIGINALISTA EM OUTROS PAÍSES.}

\subsection{Considerações iniciais}

Neste capítulo, examinaremos a adoção do enfoque originalista em questões constitucionais de diferentes países. Em primeiro lugar, verificaremos sua presença em sistemas jurídicos que guardam alguma semelhança com o modelo norteamericano: a Austrália, por pertencer à família do common law, e o Japão, que embora siga o sistema romano-germânico de direito legislado (statutory law), teve o Poder Judiciário organizado basicamente sob inspiração estadunidense.

A seguir, verificaremos que a abordagem originalista, ainda que escala bem menor, também é observada em alguns países europeus (Itália, Espanha e Portugal).

Em discurso proferido em solenidade comemorativa do cinqüentenário da Corte Constitucional italiana, em 2006, Gustavo Zagrebelsky referiu-se ao debate dos últimos anos em relação ao originalismo, "a doutrina da interpretação constitucional que adere ao puro e simples significado do texto, no momento em que foi feito (textualismo), ou de acordo com a intenção dos fundadores (intencionalismo)", em oposição à idéia da "constituição viva, sensível às exigências constitucionais do tempo mutável”. Não só rejeitou o que vê como uma tentativa de "cristalizar" a interpretação constitucional, como também aduziu que, na Europa, desde quando Justiniano tentou proteger seu Código contra as interpretações dos juristas, "a idéia do significado original soa como ingenuidade". ${ }^{128}$

\footnotetext{
${ }^{128}$ Discurso pronunciado em 22.4.2006, disponível no endereço eletrônico da Faculdade de Direito de Bolonha (www.giuri.unibo.it).
} 
Sem chegar ao exagero de remontar aos tempos do Império Romano, é compreensível que nos países da Europa continental não haja um clima muito favorável às inquietações que fizeram florescer o originalismo. A traumática experiência da Segunda Mundial mostrou à Europa que era de pouca valia a existência de uma Constituição, se não existissem mecanismos eficientes para garantir sua observância. E, para essa finalidade, foram criados tribunais constitucionais seguindo o modelo kelseniano, independentes de qualquer outra autoridade estatal, de composição plural e com integrantes nomeados com mandato fixo e mediante indicações feitas pelos demais poderes, com a precípua finalidade de interpretar e fazer valer a Constituição. ${ }^{129}$

Nesse modelo, de fato, há menos motivos para preocupação com eventual ativismo das cortes constitucionais ${ }^{130}$, pois elas têm indiscutível legitimidade democrática para atualizar a Constituição (diferentemente dos tribunais judiciários no modelo tradicional de tripartição de poderes). Não existem, ou pelo menos estarão muito atenuadas, as razões que levaram a buscar limites para a atividade de interpretação constitucional.

Finalizaremos o capítulo detendo-nos sobre a prática de métodos originalistas em países muito próximos da realidade brasileira: a Argentina, que segue o modelo de controle de constitucionalidade norteamericano, e o Chile, que adotou o modelo europeu.

\footnotetext{
${ }^{129}$ Foram criados tribunais ou cortes constitucionais em Portugal, Espanha, Áustria, Alemanha, Itália, Bélgica, Romênia, Hungria, Rússia, Polônia, Albânia, Armênia, Bulgária, Sérvia, Croácia, Macedônia, Eslovênia, Iugoslávia, Lituânia, Macedônia, República Tcheca, Eslováquia, R para não mencionar o caso peculiar da França, onde o Conselho Constitucional, com atuação basicamente de controle preventivo, também desfruta de absoluta independência em relação aos demais poderes. A esse respeito, v. Louis Favoreu, As Cortes Constitucionais, Landy, 2004 (especialmente capítulo 1, "As Cortes Constitucionais: o Modelo Europeu de Justiça Constitucional) e Alexandre de Moraes, Jurisdição Constitucional e Tribunais Constitucionais - Garantia Suprema da Constituição, Atlas, 2000, (especialmente capítulo 3, "Legitimidade e Justiça Constitucional).

${ }^{130}$ Nesse sentido, relembramos as declarações de Canotilho ao jornal Valor Econômico, em 4.11.2009, mencionadas no Capítulo 1, salientando a postura contida dos Tribunais Constitucionais europeus em matéria de políticas públicas.
} 


\subsection{Australia}

A Austrália formou-se em 1901, pela união de seis colônias britânicas na Oceania, unidas numa federação, sob um governo monárquico e parlamentarista. Sua Constituição estabeleceu a High Court como Tribunal Supremo, que entrou em funcionamento em 1903, com três juízes (a composição variou ao longo dos anos, estabilizando-se em sete, que é o número atual).

Justifica-se a pesquisa, ainda que breve, quanto à atuação desse Tribunal em matéria de interpretação constitucional, em virtude de dois fatores: a) sua posição similar à da Suprema Corte dos Estados Unidos, eis que atua numa federação, regida pelo sistema do common law; b) o fato de estar em vigor naquele país uma Constituição bastante antiga.

Segundo Jeffrey Goldsworthy, a Suprema Corte australiana tem adotado de forma consistente, ao longo de sua história, uma versão moderada de originalismo. $^{131}$

São dignas de nota as considerações desse autor a respeito da autoridade do argumento originalista:

"a evidência contextual das intenções da legislatura não são um acessório opcional, a ser levado em conta discricionariamente pelos juízes, apenas quando uma lei não é clara e requer-se criatividade para interpretá-la. Ao contrário, ela auxilia a determinar o que um estatuto significa: o que a lei é, em vez de o que ela deveria ser."132

131 Originalism in Constitutional Interpretation, Federal Law Review, v.25, 1997, pp. 2-50 (especialmente p. 49).

${ }^{132}$ Originalism in Constitutional Interpretation, cit., p. 11. 
Ele oferece inúmeros exemplos da utilização desse enfoque pela High Court, dos quais selecionamos alguns, que nos pareceram mais ilustrativos.

Logo no início de sua atuação, no caso Union Label, de 1904, a Corte proclamou que o significado de um termo na Constituição era o sentido originalmente adotado pelos que a haviam redigido, quatro anos antes.

O juiz Henry Higgins ${ }^{133}$ declarou, em 1920, que dar pleno efeito à intenção do legislador é "a regra fundamental de interpretação, à qual todas as demais estão subordinadas".

No caso King v. Jones, de 1972, o Chief Justice Barwick assinalou:

"Há algumas proposições básicas em interpretação constitucional que está acima de qualquer controvérsia. As palavras da Constituição devem ser lidas no sentido natural em que elas vieram à luz, nas circunstâncias de sua promulgação pelo Parlamento Imperial, em 1900. Esse sentido permanece, além do alcance de qualquer legislatura, sujeito apenas a alteração pelo modo previsto no art. 128 da Constituição. A conotação das palavras empregadas na Constituição não muda, ainda que a variação de eventos e das atitudes possa, em cdertas circunstâncias, ampliar a denotação ou alcance dessas palavras. Estas afirmativas estão plenamente documentadas nas decisões anteriormente mencionadas desta Corte, que tem o encargo de decidir, com autoridade final, os sentidos denotativo e conotativo da linguagem utilizada pela Constituição". ${ }^{134}$

Em 1977, no caso McGuire v. Simpson, o mesmo juiz assinalou que para bem interpretar o Judiciary Act, de 1903, era absolutamente indispensável examinar o contexto histórico em que editado.

${ }^{133}$ Todos os juízes citados neste item são (ou foram) membros da High Court australiana.

$134 \mathrm{O}$ texto completo da decisão está disponível no endereço eletrônico http://www.austlii.edu.au/au/cases/cth/high_ct/128clr221.html (acesso em 31.12.2010). O art. 128 referese ao processo de emenda da Constituição. Retornaremos, adiante, a esta decisão, para esclarecer a distinção feita entre denotação e conotação. 
De modo semelhante, no julgamento do caso Cooper Brookes $v$. $F C T$, em 1981, os juízes Mason e Wilson, em voto conjunto, assinalaram que "o objetivo fundamental da interpretação das leis, em qualquer caso, é determinar a intenção do legislador”.

E em 1993, no caso Cheattle, para definir se as decisões do júri deveriam ser necessariamente tomadas por unanimidade, mesmo não havendo expressa disposição constitucional a respeito, a Corte foi buscar a solução no significado com que os redatores da Constituição tinham em mente ao estabelecer o tribunal popular, um século antes, com base no seu modelo norteamericano:

"Ao tempo da adoção da Constituição Australiana, a posição esmagadoramente majoritária nos Estados Unidos favorecia a conclusão de que a expressão julgamento pelo júri, no art. III, que foi adotada no art. 80 de nossa Constituição, trazia consigo o requisito da unanimidade".

Isso naturalmente não significa que a Suprema Corte australiana deixe de fazer a necessária atualização do texto constitucional, aplicando-o a uma realidade muito diferente daquela que viviam os fundadores do país. Para tanto, valese de algumas técnicas que, preservando o sentido original dos conceitos da Constituição, amplia sua aplicação a situações que não podiam ser previstas há um século.

Uma das mais recorrentes técnicas de atualização é o recurso ao binômico conotação/denotação, assim explicado pelo Juiz-presidente Barwick no importante trecho, acima mencionado, da sentença proferida no caso King $v$. Jones: “A conotação das palavras empregadas na Constituição não muda, embora a variação dos eventos e das atitudes possa, em certas circunstâncias, ampliar a denotação ou alcance dessas palavras”. Outro exemplo é dado pelo Juiz Dyson Heydon: 
“Um exemplo usual dessa operação positiva de distinguir conotação/denotação diz respeito ao transporte aéreo. Em 1900 ele não existia: os irmãos Wright não voaram senão em 1903. Porém, em 1945, o poder conferido pelo art. 51 para legislar sobre comércio e negócios foi aplicado para a regulação do transporte aéreo. $^{135}$ A conotação de comércio e negócios não mudou, mas a denotação, sim."

Em texto de 1997, Haig Patapan apontava que a High Court vinha aumentando lenta, porém consistentemente o reconhecimento do valor da pesquisa histórica para melhor interpretar a Constituição. ${ }^{137}$ E cita como exemplo a decisão no caso Cole v. Whitfield, de 1988, em que se afirmou que os debates da Convenção Constituinte deveriam ser consultados "com o propósito de identificar o sentido em que a linguagem foi usada à época, a matéria em relação à qual essa linguagem se referia e a natureza e objetivos do movimento em prol da federação, do qual o esboço da Constituição acabou por surgir".

Também nesse sentido aponta a decisão proferida em New South Wales v. Commonwealth, também conhecido como Corporations case, de 1990, em que a Suprema Corte recorreu aos citados debates para delimitar quais seriam os poderes reconhecidos às corporações da Comunidade Britânica em face da federação que se formava.

E concluía o citado articulista que esse papel mais proeminente que se vinha atribuindo à interpretação originalista traria "conseqüências significativas" para o desenvolvimento do constitucionalismo australiano, sendo importante admitir que "a intenção dos fundadores irá influenciar fortemente, senão até mesmo moldar, o debate político, filosófico e jurisprudencial na Austrália". ${ }^{138}$

\footnotetext{
${ }^{135}$ A referência é ao caso Australian National Airways Pty Ltd. V. The Commonwealth.

${ }^{136}$ Theories of Constitutional Interpretation: a Taxonomy - Federal Law Review, n. 25, 1997, pp. 1-77 (disponível em http://heinonline.org, acesso em 24.10.2010).

${ }^{137}$ Haig Patapan, The Dead Hand of the Founders? Original Intent and the Constitutional Protection of Rights and Freedoms in Australia - Federal Law Review, vol. 25/2, 1997, pp. 211-236 (texto disponível em www.98griffith.edu.au/dspace/handle/10072/16203; acesso em 24.10.2010)

${ }^{138}$ Haig Patapan, cit., pp. 212 e 225-226.
} 


\subsection{Japão}

A Constituição japonesa tem uma história singular. Foi promulgada em 3 de novembro de 1946, entrando em vigor em 3 de maio de 1947, em plena ocupação do país por tropas norteamericanas. Naquele período, o país estava privado de sua soberania, uma vez que era indiscutível que nenhuma decisão importante era tomada sem o consentimento do Supremo Comando Militar das forças de ocupação (General Headquarters, ou simplesmente GHQ). O próprio projeto de Constituição foi elaborado, basicamente, por uma pequena comissão de japoneses e norteamericanos, sob os olhares atentos do General McArthur. ${ }^{139}$

A Constituição foi aprovada pela Dieta, e aceita como legítima pelo povo japonês. ${ }^{140}$ Todo o material relativo ao processo de elaboração da nova Carta Magna (documentos, esboços e anteprojetos, propostas, deliberações e debates parlamentares) está disponível, inclusive em inglês, no sítio oficial do Parlamento japonês $^{141}$, o que é indicativo da relevância que se empresta ao elemento histórico, naquele país, em matéria de interpretação constitucional.

O ponto relevante para este trabalho é que o argumento originalista está presente em uma das maiores polêmicas constitucionais japonesas, que diz respeito à interpretação do art. $9^{\circ}$ da Constituição, conhecido como a "cláusula pacifista" ou de "renúncia à guerra".

Assim dispõe o referido artigo:

“Artigo 9 . Aspirando sinceramente uma paz internacional baseada na justiça e na ordem, o povo japonês renuncia para sempre à guerra como direito soberano da nação e à ameaça ou o uso da força como meios de solução da disputas internacionais.

\footnotetext{
139 Teria partido diretamente de McArthur a fixação de três pontos inegociáveis, que deveriam constar necessariamente da nova Constituição japonesa: renúncia à guerra, abolição do sistema feudal, garantia dos direitos humanos.

${ }^{140}$ Kazuyuki Takahashi, Comment, Law \& Contemporary Problems, n. 53, p. 189, 1990.

${ }^{141}$ Endereço eletrônico: http://www.ndl.go.jp/constitution/e/index.html (último acesso em 4.1.2011).
} 
A fim de cumprir o objetivo do parágrafo anterior, as forças de terra, mar e ar, bem como outro potencial bélico, jamais serão mantidos. $\mathrm{O}$ direito de beligerância do Estado não será reconhecido." ${ }^{142}$

Para muitos estudiosos, esse artigo teria sido simplesmente imposto pelas forças de ocupação norte-americanas, com vistas a assegurar que o Japão nunca mais representaria uma ameaça militar ao Ocidente, e aceito pelas autoridades japonesas como inevitável contrapartida para a manutenção da figura do Imperador. ${ }^{143}$

A primeira parte desse dispositivo é interpretada, sem maiores dificuldades, como proibição pura e simples da guerra, inclusive quando alegadamente defensiva. O debate surge em relação ao segundo parágrafo: ele proibiria qualquer tipo de força bélica, inclusive de natureza defensiva?

No entanto, é certo que nos debates havidos na Dieta, que precederam a aprovação da Constituição, o sentido que o governo anunciou para o art. $9^{\circ}$ era o de proibição total de quaisquer forças militares, sob qualquer justificativa. Esse ponto é assim explicado por Sayuri Umeda:

"Quando a Dieta Imperial discutiu a nova Constituição em 1946, o Japão não tinha nenhuma força militar. Durante a $90^{\mathrm{a}}$ sessão da Câmara de Representantes, quando perguntado pelo deputado Fujio Hara se o art. $9^{\circ}$ implicava $o$ abandono do direito de autodefesa, o primeiro-ministro Shigeru Yoshida (...) respondeu que 'a estipulação constante do projeto, em relação à renúncia à guerra, não nega diretamente o direito de autodefesa; porém, como resultado da proibição de qualquer potencial bélico e do direito de beligerância (...) o Japão renuncia até mesmo à guerra baseada no direito de autodefesa'...". ${ }^{144}$

\footnotetext{
${ }^{142}$ Tradução em português obtida em Constituição do Brasil e Constituições Estrangeiras, vol. II, ed. Senado Federal, Brasília, 1987.

143 Nesse sentido: Kazuyuki Takahashi, Comment, 53 Law \& Contemporary Problems 189, 1990. Michel Kelly discorda dessa tese, afirmando que o processo constituinte japonês foi feito em regime de cooperação (entre americanos e japoneses), não de imposição (The Article 9 Pacifism Clause and Japan's Place in the World, in Wisconsin International Law Journal, v. 25, n. 3, 2007, pp. 491-505 disponível em www.hosted.law.wisc.edu/wilj/issues/25/3/kelly.pdf - acesso em 1.11.2010).

${ }^{144}$ Umeda, artigo citado, item V-A.
} 
Noutra intervenção, o primeiro-ministro Yoshida considerou "perigoso" admitir o direito de autodefesa, uma vez que "a maioria das guerras foram deflagradas por esse motivo, por isso é melhor impedir a guerra em qualquer hipótese. Reconhecer e justificar a guerra em autodefesa apenas serviria para incentivar outra guerra". 145

Essas declarações não deixam nenhuma dúvida quanto ao sentido que a Dieta, e também o povo japonês, entendiam então aquela cláusula: todas as forças militares, qualquer que fosse o seu propósito, estavam proibidas. ${ }^{146}$

O comentário que se encontra no sítio oficial do Parlamento japonês bem ilustra a questão: “...o segundo parágrafo, efetivamente proibindo ao Japão a manutenção de forças armadas e o direito de beligerância, tornaria afinal impossível a realização de uma guerra defensiva”. No entanto, logo após o início da Guerra da Coréia, teve início a organização de forças nacionais de segurança, culminando, em 1954, com a criação das "Forças de Autodefesa" (Jieitai ou, na sigla em inglês, SDF), surgindo então um sério questionamento em face da Constituição:

"A força evoluiu de policial para defensiva, o que causou séria disputa quanto à interpretação do artigo $9^{\circ}$ da Constituição. Após o final da guerra fria, nos anos 1990, o Japão envolveu-se numa situação flutuante em que os problemas relativos à interpretação e aplicação do artigo $9^{\circ}$ tornaram-se sérios, e continuam a perseguir o governo japonês até hoje". ${ }^{147}$

\footnotetext{
${ }^{145}$ Umeda, artigo citado, item V-B.

${ }^{146}$ Nesse sentido: James Auer, Article Nine of Japan's Constitution, Law and Contemporary Problems, 171, 1990 (disponível em http://www.jstor.org/pss/1191849); Kazuyuki Takahashi, Comment, cit., p. 189.

${ }^{147}$ Texto disponível em http://www.ndl.go.jp/constitution/e/ronten/02ronten.html.
} 
Mark Chinen, em extenso trabalho sobre a matéria ${ }^{148}$, demora-se sobre a análise do processo de elaboração e redação do artigo $9^{\circ}$ e rejeita a idéia de sua imposição; assevera que a "ampla maioria dos cidadãos japoneses, sentindo-se traída pela liderança política que levara o país à guerra, rapidamente adotou a nova Constituição, inclusive o Artigo 9'”. E prossegue, louvando-se na opinião de John W. Dower, assinalando que os ideais de desmilitarização e democratização, presentes na época de promulgação da Carta, ainda hoje são fortes no imaginário popular. ${ }^{149}$

Argumenta-se, por outro lado, que a idéia de abolir forças de autodefesa é irrealista, e colocaria em perigo a própria existência soberana do país. No entanto, um ponto é certo: a proibição de forças armadas com poder ofensivo é clara. Este é o sentido original da norma ${ }^{150}$, tal como entendido pelo parlamento que aprovou a Constituição e, mais importante, como foi compreendido e aceito pelo povo japonês. ${ }^{151}$

Ocorre que, como é público e notório, há várias décadas é crescente o poderio militar japonês. As Forças de Autodefesa foram criticadas desde a sua criação porque - tal como parecia ao primeiro ministro Yoshida - o propósito alegadamente defensivo não oferecia nenhuma garantia contra futuro incremento do poder militar. ${ }^{152}$

E foi exatamente isto o que aconteceu. Os Estados Unidos, que em 1946 eram os principais interessados em evitar o ressurgimento do poderio militar japonês, uma década depois já viam o Japão como grande aliado na região do Pacífico, em contraposição à China e à Coréia do Norte. Assim, é patente que a SDF, criada para fins supostamente defensivos, tem hoje imenso potencial bélico, já tendo atuado

\footnotetext{
${ }^{148}$ Mark Chinen, Article 9 of the Constitution of Japan and the use of procedural and substantive heuristics for consensus - in Michigan Journal of International Law, n. 27, 2006, pp. 55-114.

${ }^{149}$ Chinen, cit., p. 94.

${ }^{150}$ Umeda, artigo citado, item VII.

${ }^{151}$ Takahashi, cit., p. 189; Sayuri Umeda, Japan - Article 9 of the Constitution, Law Library of Congress, 2004.

${ }^{152}$ Umeda, cit., item F.
} 
inclusive em missões externas (na Guerra do Golfo, em 1990) ${ }^{153}$. Essa situação é inegavelmente contrária à letra e ao espírito da Constituição.

Surgiram inúmeros movimentos pacifistas, não só no Japão mas também internacionais, defendendo uma interpretação originalista do art. $9^{\circ}$, tal como ele foi aprovado pela Dieta em 1946, qual seja: como uma proibição absoluta à existência de quaisquer forças com potencial bélico, ainda que com alegado intuito de autodefesa. $^{154}$

Chinen relata que há um "sério debate" quanto à constitucionalidade da SDF, e muitos grupos, incluindo os "idealistas de esquerda", intelectuais e movimentos sindicais, defendem a manutenção dos "ideais pacifistas incorporados e implementados na Constituição" ${ }^{155}$. O Novo Komeito, influente partido político, rejeitou formalmente em 1999 a "reinterpretação" do art. 9., defendendo a observância de seu significado original, isto é: a inconstitucionalidade de qualquer força militar, inclusive de autodefesa. ${ }^{156}$

Kenneth Port examina em profundidade o processo de elaboração do art. $9^{\circ}$. O primeiro-ministro Shidehara, que formalmente propôs a cláusula de renúncia à guerra, escreveu que não faria sentido admitir que o Japão retivesse uma pequena força defensiva, pois esta seria inútil para evitar uma agressão estrangeira, e haveria o permanente risco de, mediante pequenos e graduais reforços, chegar-se à criação de um expressivo poderio militar. Por isso, "em vez de reter armamentos obsoletos e inúteis, seria preferível optar pela abolição completa das armas e renunciar à guerra". ${ }^{157}$ Além disso, ele também cita as discussões prévias da matéria no governo japonês, a demonstrar que a renúncia à guerra e a qualquer tipo de força militar eram

${ }^{153}$ Segundo Chinen, em 2006 o efetivo da SDF era de 240.000 integrantes, consumindo um orçamento anual de cinquenta bilhões de dólares (art. cit., p. 59), um dos maiores do mundo.

${ }^{154}$ Registre a existência de uma rede pacifista internacional, sugestivamente Global Article 9 Campaign (www.article-9.org).

${ }^{155}$ Chinen, cit., pp. 59 e 76.

${ }^{156}$ Chinen, cit., p. 81.

${ }^{157}$ Kijuro Shidehara, Cinquenta anos de Relações Exteriores (original em japonês), apud Kenneth Port, Article 9 of the Japanese Constitution and the Rule of Law, in Cardozo Journal of International \& Comparative Law, n. 13, 2005, p. 139. 
então consideradas como as duas garantias da segurança do Japão no futuro, além de tornar a futura Constituição um "marco em sua época". Estava muito clara, nessa etapa de discussão do futuro texto constitucional, a compreensão de que um "direito de autodefesa" poderia ser utilizado como pretexto para a guerra, e por isso ele não foi contemplado. O esboço inicial do artigo, que permitiria a guerra "não ofensiva", pois modificado para deixar explícito que o país não teria nenhum tipo de força militar, sob qualquer pretexto. ${ }^{158}$

Kenneth Port conclui, por isso, que o artigo $9^{\circ}$ foi "o catalisador do pacifismo japonês após a Segunda Guerra Mundial", e seu "significado original (...) era abandonar para sempre o poderio militar, para quaisquer finalidades". 159

Outra, naturalmente, é a posição oficial do governo japonês, que insiste que suas forças militares têm propósitos unicamente defensivos, o que não seria negado pelo art. $9^{\circ}$. Nesse sentido vem se manifestando o Departamento de Legislação do Gabinete japonês (em inglês conhecido como CLB, Cabinet Legislation Bureau), um órgão de muito prestígio, especialmente em matéria de interpretação constitucional.

Quando pressionado pelas correntes pacifistas, o CLB sustenta que, havendo discrepância entre as exigências da realidade e a Constituição, esta deve ser modificada. ${ }^{160}$ Uma afirmação como esta, no contexto japonês, é particularmente significativa, pois desde que entrou em vigor a Constituição jamais foi emendada, e o procedimento para reforma é particularmente dificultoso. ${ }^{161}$

O constitucionalista Kazuyuki Takahashi também salienta a contradição entre a realidade e o que estatui o art. $9^{\circ}$, e conclui que há somente duas

\footnotetext{
${ }^{158}$ Kenneth Port, cit., pp. 142-143. Essas discussões estão disponíveis (apenas no idioma original) no já mencionado endereço eletrônico do Parlamento japonês: http://www.ndl.go.jp/constitution/shiryo/04/118shoshi.html (acesso verificado em 02.01.2011).

${ }^{159}$ Article 9..., cit., p. 145

${ }^{160}$ Umeda, cit., item VI.

${ }^{161}$ De acordo com o art. 96 da Constituição japonesa, uma emenda deve ser aprovada por maioria de dois terços em cada uma das Casas do parlamento, e ainda submetida à ratificação popular.
} 
soluções para o problema: ou abolir as Forças de Autodefesa, ou emendar a Constituição. ${ }^{162}$

A tese da reforma do art. $9^{\circ}$ vem sendo há vários anos defendida por um dos partidos majoritários, o Liberal Democrático, que apresentou uma proposta oficial nesse sentido em 2005, em que a segunda parte do art. $9^{\circ}$ é totalmente reformulada, para admitir expressamente a existência da SDF, de modo a constitucionalizar o direito de autodefesa. ${ }^{163}$ Sucessivos gabinetes têm se empenhado na mudança da Constituição, até o momento sem sucesso. ${ }^{164}$

De certo modo, ao propugnar por essa reforma, o próprio governo japonês acabou, indiretamente, por respaldar a tese dos pacifistas: o sentido original do art. $9^{\circ}$ é incompatível, senão com a existência, ao menos com a configuração atual da SDF.

A esse respeito, Takahashi faz uma percuciente observação: uma vez que falharam as tentativas de reforma constitucional, por não ser alcançada a maioria parlamentar de dois terços, o governo mudou de estratégia, adotando uma “emenda por interpretação", passando então a sustentar que

"o potencial bélico proibido pela Constituição significa uma força suficiente para desencadear eficazmente uma guerra moderna, e a SDF não teria essa força, sendo por isso constitucional. Esse argumento, todavia, é ilógico, porque se a SDF não pode desencadear eficazmente uma guerra moderna defensiva, então ela não tem nenhuma utilidade". ${ }^{165}$

Trata-se, segundo o mesmo autor, de "uma falsa interpretação", porque o assunto foi debatido antes de ser promulgada a Constituição, e o potencial bélico foi "clara e explicitamente rejeitado, mesmo para autodefesa", sendo esta a

\footnotetext{
162 Comment, cit., p. 189.

${ }^{163}$ Umeda, cit., pp. 30-31.

${ }^{164}$ Kelly, artigo citado, especialmente pp. 494-495, 501 e 505.

${ }^{165}$ Comment, cit., p. 190.
} 
compreensão da maioria dos constitucionalistas japoneses. E conclui Takahashi, numa perspectiva de evidente inspiração originalista:

"O sentido original [original meaning] é inteiramente claro. Como professor de direito constitucional, eu não posso distorcer o claro significado da Constituição. Se nós nos curvamos diante do fait accompli, então não haverá constitucionalismo nem Estado de Direito." 166

A polêmica permanece, sendo oportuno observar que não foi possível alcançar uma solução pela via judicial. $\quad$ E isto porque a jurisdição constitucional no Japão é exercida muito timidamente: em sessenta e dois anos de atividades, somente em oito ocasiões a Suprema Corte usou seu poder de declarar a inconstitucionalidade de leis - e em nenhum desses casos estava em jogo algum assunto de maior relevância. Tais fatores levaram diversos estudiosos a considerá-la "a mais conservadora corte constitucional do mundo". ${ }^{167}$

Jun-ichi Sato, professor da Universidade de Osaka, acredita que a "relutância" da Suprema Corte em invalidar leis ou atos governamentais deve-se aos "mandatos muito curtos" de seus juízes ${ }^{168}$ e à constante substituição de presidentes da

\footnotetext{
${ }^{166}$ Comment, cit., p. 190. A expressão em francês consta do original. O caráter majoritário desse entendimento, no campo acadêmico, também nos foi afirmado pela professora Miyuki Sato, em comentário gentilmente enviado por e-mail, em 23.11.2010.

${ }^{167}$ V. David Law: The Anatomy of a Conservative Court: Judicial Review in Japan, 2009:15461547. A propósito da pequena atuação da Suprema Corte em matéria de controle de constitucionalidade, v. tb. Miyuki Sato, Controle de Constitucionalidade - uma sucinta comparação entre o Brasil e o Japão, Revista da Faculdade de Direito da USP, vol. 96 (2001), pp. 729-736 (especialmente p. 732).

${ }^{168}$ É curioso o motivo invocado, pois os juízes da Suprema Corte, após terem sua nomeação ratificada pelo povo, nas eleições gerais, têm pelo período mínimo de dez anos (art. 79 da Constituição).
} 
Corte (foram dezessete, de 1946 até 2010), ${ }^{169}$ o que "criou uma falta de consistência" nos julgamentos e impediu o desenvolvimento de "precedentes claros"170.

Porém, no que diz respeito à interpretação do art. $9^{\circ}$, o fato é que a Suprema Corte tem mantido a postura de evitar confrontos com o Poder Executivo. No caso Sunakawa, de 1959, embora reconhecendo que a renúncia à guerra, prevista no art. $9^{\circ}$ da Constituição, traduzia a duradoura aspiração pacifista do povo japonês, o tribunal afirmou que

“esse artigo (...) proíbe a manutenção do assim chamado potencial de guerra, mas certamente nada contém que possa negar o direito de autodefesa inerente à soberania desta nação. $\mathrm{O}$ pacifismo advogado por nossa Constituição nunca quis significar ausência de defesa ou não-resistência”.

Da mesma forma, no voto em separado do Juiz-presidente Kotaro

Tanaka constou:

"O espírito de pacifismo incorporado no art. $9^{\circ}$ da Constituição, conjuntamente com o conceito enunciado no Preâmbulo, é imutável. Em essência, renuncia-se para sempre à guerra ofensiva e ao uso da força como meio de resolver conflitos internacionais. No entanto, não se deve incorrer no erro de pensar que o Japão, ao assim fazê-lo, esteja automaticamente isento do dever de manter a paz e a segurança na comunidade internacional. A menos que nos libertemos da premissa egocêntrica de colocar os interesses nacionais em primeiro lugar, e assumir a postura de aderir ao princípio universal de moralidade política tão nitidamente declarado no Preâmbulo da Constituição, ou seja, sem que se considere este assunto do devido

\footnotetext{
${ }^{169}$ Ao tempo em que Jun-ichi Sato escrevia, dezesseis juízes haviam exercido a presidência da Suprema Corte (a mais recente nomeação de um presidente ocorreu em novembro de 2008).

${ }^{170}$ Jun-ichi Sato, Judicial Review in Japan, in Loyola of Los Angeles Law Review, 2008, vol. 41, pp. 603-628.
} 
ponto de vista de sua dimensão internacional, será uma tarefa impossível interpretar o art. $9^{\circ}$ da Constituição”. ${ }^{171}$

Em data mais recente, no julgamento dos casos 164/82 e 165/82, a Suprema Corte defrontou-se com a alegação de que o art. $9^{\circ}$ seria fator impeditivo da instalação de uma base militar em Hyakuri, na cidade de Ogawa. No entanto, a questão jurídica foi contornada, preferindo a Corte apelar para "a atitude da sociedade" em relação à existência das Forças de Autodefesa - em outros termos, a predominante aceitação da existência dessas Forças pela opinião pública. É que se denota do seguinte trecho do acórdão, em que se diz que a causa

“... não há de ser necessariamente resolvida pela determinação de qual das muitas e conflitantes interpretações do Artigo 9 é a correta. Antes, a questão de saber se o ato [impugnado] é tão antissocial, a ponto de nulificar sua validade sob a ordem de valores da lei civil, deve ser julgada à luz de sua aceitação pela sociedade (ou pela falta dela). Isto pode ser verificado observando-se condições reais, tais como a opinião pública (ou seja, o modo pelo qual pessoas de todos os níveis interpretam o art. $9^{\circ}$ ), o fato da existência das Forças de Autodefesa, e a atitude da sociedade em geral em relação às suas atividades". ${ }^{172}$

${ }^{171}$ Sunakawa Case, Suprema Corte do Japão, n. 710/159, j. 16.12 .1959 (texto em inglês obtido em www.courts.go.jp/english/judgments) .

${ }^{172}$ Hyakuri Air Base Case, Suprema Corte do Japão, Terceira Câmara, 20.6.1989; decisão dos juízes Massami Ito, Mitsuhiko Yasuoka e Toshio Sakaue; tradução inglesa obtida em www.courts.go.jp/english/judgments (acesso em 7.11.2010). 


\subsection{Itália}

Em que pese a autorizada opinião de Zagrebelsky, mencionada ao início deste capítulo, relativamente à "ingenuidade" da busca pelo sentido original da Constituição, é justamente na Itália que as idéias originalistas alcançaram, comparativamente, maior repercussão que em outros países europeus.

Cremos que isto se deva, ao menos em parte, ao respeito que a cultura jurídica italiana empresta à intenção do legislador. Um exemplo disto pode ser encontrado no art. 12 do Código Civil, sob a rubrica "Da Interpretação da Lei", dispondo que "ao aplicar a lei não se pode atribuir a ela um sentido diverso daquele que se extrai claramente do significado próprio das palavras, segundo a conexão entre elas e a intenção do legislador".

Em seminário realizado na Universidade de Catânia, em 5 de outubro de 2007, sugestivamente denominado "Trabalhos Preparatórios e Original Intent na Jurisprudência da Corte Constitucional" ${ }^{173}$, diversos professores discutiram a presença da argumentação originalista em decisões daquele Tribunal, nos mais variados temas.

Assim, Felice Giuffrè e Ida Nicotra apontaram o enfoque originalista em diversas sentenças daquele Tribunal: 183/1973, 39/1986, 200/2006, 333/1993. Nesta última, que consideram "emblemática”, a Corte Constitucional fez expressa referência aos debates constituintes para esclarecer o significado do princípio de "imparcialidade da administração" (art. 97 da Constituição Italiana), e com base nele declarar a inconstitucionalidade de uma lei regional, numa decisão "em linha de continuidade com o intento originalista", que assumia "particular significado ao propor uma leitura do preceito constitucional coerente com o espírito originário do Texto Fundamental". E concluíram os autores que

${ }^{173}$ A expressão em inglês foi utilizada na denominação original. 
"Em definitivo, parece que o recurso ao cânone originalista seja útil para reforçar a decisão adotada pela Corte através de outros cânones interpretativos, enquanto não é tomado em consideração qual o critério decisivo para atribuir significado a uma determinada disposição". ${ }^{174}$

Em outro trabalho apresentado no mesmo seminário, Lucia Scianella ressaltou que a Corte Constitucional, quando chamada a definir os limites de ação dos demais poderes, "parece privilegiar a referência ao intento original do constituinte", de modo a limitar seu próprio "poder criativo e sobretudo político", em nítida postura de auto-contenção. ${ }^{175}$ Cita alguns exemplos dessa postura, dos quais vamos destacar dois.

A possibilidade de que o voto de desconfiança de uma das Casas do Parlamento seja dirigido individualmente a um ministro, embora não referida expressamente nos arts. 94 e 95 da Constituição italiana, foi afirmado pela Corte na sentença n. 7/96, após minucioso exame dos trabalhos preparatórios da Assembléia Constituinte, atribuindo-lhes, nas palavras de Lucia Sciannella, "dignidade não inferior da à atribuída aos cânones hermenêuticos mais usuais". De fato, em certa passagem da sentença, a Corte refere-se expressamente à busca da "vontade do constituinte" para afinal admitir a "responsabilidade política do componente singular do Governo" e possibilidade de sua demissão individual. ${ }^{176}$

Na sentença n. 200/2006, a propósito da recusa do Ministro da Justiça em dar seguimento a um ato de concessão de graça, por parte do Presidente da República, a Corte recorreu à interpretação histórica para "dar suporte à vontade do constituinte e à interpretação que prevaleceu em sede de trabalhos preparatórios do

\footnotetext{
${ }^{174}$ Felice Giuffrè e Ida Nicotra ${ }_{5}$ Lavori Preparatori ed Original Intent nella Giurisprudenza della Corte Costituzionale, Giappichelli, 2008, pp. 1-10.

${ }^{175}$ Lucia G. Sciannella, L'Argomento dell'original intent nella Giurisprudenza Costituzionale in Tema di Forma di Governo, in Lavori Preparatori ed Original Intent..., cit., pp. $43-77$ (especialmente p. 76).

${ }^{176}$ Lúcia G. Sciannella, cit. , p. 70.
} 
texto constitucional", para então confirmar que esse poder era reconhecido em caráter exclusivo ao Chefe de Estado. ${ }^{177}$

Especificamente em matéria de direitos fundamentais, Chiara Tripodina encontrou o argumento originalista em nada menos do que 58 sentenças da Corte Constitucional, porém "sempre empregado ad adiuvandum, para reforçar interpretações que a Corte alcançou por meio de outros critérios". ${ }^{178}$ A conclusão semelhante chegou Tiziana Fortuna, em matéria de proteção ao meio ambiente. ${ }^{179}$

De modo diverso, quando se trata das relações entre política e administração pública, a Corte Constitucional tem reservado à pesquisa da intenção original do constituinte "um espaço precioso e essencial", como assinala Giovanna Majorana, citando como exemplos as sentenças 453/1990, 333/1993, 145/2002, 103 e 104/2007.

A constância com que a Corte recorre aos trabalhos preparatórios pode ser aferida, por exemplo, no seguinte trecho da Sentença n. 28/1998, que trata da correta interpretação da garantia inscrita no art. 51 da Constituição:

"Esta Corte tem constantemente afirmado, desde a Sentença n. 6 de 1960, que a expressão do art. 51 conservar o posto de trabalho, interpretada também à luz do debate na Assembléia Constituinte, no qual se manifestou o intento de fixar o princípio que, quando um trabalhador é investido em um cargo público, não deve por isso ser licenciado, mas retido em dispensa ou expectativa (Assembléia Constituinte, primeira subcomissão, sessão de 15 de novembro de 1946), garante sobretudo 'o direito a manter a relação de trabalho ou emprego' (sentença n. 111 de 1994) e de modo algum tutela, como afirma o juízo de origem, o interesse à conservação simplesmente do posto originário de trabalho".

\footnotetext{
${ }^{177}$ Lúcia G. Sciannella, cit., p. 72

${ }^{178}$ Chiara Tripodina, L’Argomento Originalista nella Giurisprudenza Costituzionale in Materia di Diritti Fondamentali, in Lavori Preparatori ed Original Intent..., cit. pp. 229-272 ( o trecho citado encontra-se a p. 231).

${ }^{179}$ L'Original Intent nell'Atività Ermeneutica della Corte Costituzionale e la sua Valenza in Materia di "Tutela dell'Ambiente”, in Lavori Preparatori ed Original Intent..., cit. pp. 330-342.
} 
Destacaremos, por fim, a Sentença n. 422/95, em que a Corte Constitucional italiana examinou uma lei que intentou obrigar os partidos políticos a reservar vagas para ambos os sexos nas listas de candidatos a eleições parlamentares. Num primeiro momento, levou-se em conta a intenção dos constituintes, como se vê na seguinte passagem:

"Pelo contrário, mesmo relativamente à formulação desta norma, poderia parecer supérflua a especificação 'de ambos os sexos', sendo suficiente, por si só, a expressão 'todos os cidadãos'; é porém compreensível que os constituintes - assim como já no art. 48 haviam insistido que 'são eleitores todos os cidadãos, homens e mulheres,...' - tenham querido reforçar, relativamente aos empregos públicos e cargos eletivos, o preceito explícito da igualdade entre os dois sexos. Deve-se ter em conta o contexto histórico no qual eles operavam: as leis vigentes excluíam as mulheres de boa parte dos empregos públicos, e o eleitorado ativo e passivo, a elas franqueado (ou: admitido) em 1945 (...) foi exercido pela primeira vez, no campo político, com a eleição da própria Assembléia Constituinte. Também dos trabalhos preparatórios e da comparação do texto da Carta Constitucional com aquele proposto pela 'Comissão dos Setenta e Cinco', se extraí que se queria sublinhar a igualdade entre os dois sexos, no significado acima lembrado, sem possibilidade de dúvida: foi adicionada a menção a cargos eletivos, e suprimido o inciso 'de acordo com suas capacidades', devido ao temor que pudesse justificar a manutenção das exclusões discriminatórias em relação às mulheres.

Assim estabelecido o alcance da norma constitucional, a Corte perscrutou os trabalhos preparatórios e debates do legislador ordinário, para ao final proclamar que o real propósito deste - assegurar reserva de vagas para as mulheres, 
ainda que disfarçado sob uma fórmula neutra ("ambos os sexos") - afrontava o princípio da igualdade, tal como concebido pelo constituinte:

Verifica-se, [do exame] dos trabalhos preparatórios, que o dispositivo que impõe uma reserva de quota em razão do sexo dos candidatos, embora formulada de modo, por assim dizer, "neutro", direcionando-se tanto a homens quanto a mulheres, foi proposta e votada (depois de amplo e intenso debate) com a declarada finalidade de assegurar às mulheres uma reserva de vagas nas listas de candidatos, a fim de favorecer as condições para um reequilíbrio da representação dos sexos nas assembléias comunais. No entendimento do legislador, portanto, a norma destinava-se a configurar um tipo de ação positiva, voltada a favorecer a obtenção de uma paridade, não apenas formal, mas também substancial entre os dois sexos no acesso aos cargos públicos eletivos...".

\subsection{Espanha}

A Constituição Espanhola de 1978 criou o Tribunal Constitucional $^{180}$, que iniciou suas atividades em fevereiro de 1980, encarregado do controle de constitucionalidade (preventivo e posterior, este por via concentrada ou, em casos concretos, por remessa de um tribunal judiciário ou recurso de amparo), além de atribuições de natureza política, como a solução de conflitos entre órgãos constitucionais do Estado. É composto por doze membros, nomeados pelo Rei, mas sempre por indicação dos outros poderes: quatro membros indicados pelo Congresso dos Deputados, quatro pelo Senado, dois pelo Governo e dois pelo Conselho Geral do Poder Judiciário. Os juízes do

\footnotetext{
${ }^{180}$ Entre 1931 e 1936, a Espanha teve a experiência de um Tribunal de Garantias Constitucionais, malograda diante da eclosão da Guerra Civil e instauração do regime ditatorial franquista.
} 
Tribunal têm mandato de nove anos, havendo renovações parciais (de um terço dos integrantes) a cada três anos. ${ }^{181}$

A constante renovação da composição e seu caráter plural, com evidente predomínio das indicações pelos poderes políticos (dez, em um total de doze lugares), conferem ao Tribunal Constitucional indiscutível legitimidade democrática para a interpretação constitucional. Mesmo neste caso, porém, observa-se o respeito à posição do legislador e, em especial, do constituinte.

Segundo Javier Pérez Royo, na ordem jurídica espanhola consideram-se o Parlamento e o Tribunal Constitucional como "intérpretes privilegiados" da Constituição, em posição superior aos juízes e ao conjunto dos cidadãos, num arranjo que consagra o respeito ao princípio democrático:

"O primeiro intérprete da Constituição, e de longe o mais importante, é o legislador. Ele é o intérprete normal e ordinário da Constituição. Consequentemente, a Constituição é uma norma jurídica que remete em primeiro lugar a um intérprete político. (...) E é, ademais, um intérprete privilegiado, na medida em que é o representante democraticamente eleito pelos cidadãos e expressa, portanto, a vontade geral. Justamente por isso, sua interpretação, em forma de lei, se impõe a toda a sociedade.

O segundo intérprete privilegiado é o Tribunal Constitucional. Apenas ele pode rever a interpretação da Constituição efetuada pelo legislador. E somente pode fazê-lo juridicamente, isto é, apenas pode controlar a lei, mas nunca a motivação política que conduziu o legislador. É apenas sua tradução jurídica que pode ser controlada, e somente pelo Tribunal Constitucional". ${ }^{182}$

E essa proeminência do Parlamento e do Tribunal Constitucional são explicadas, pelo referido autor, à luz dos pressupostos do Estado Constitucional:

\footnotetext{
${ }^{181}$ Louis Favoreu, As Cortes Constitucionais, São Paulo, ed. Landy, 2004, pp. 103-112; Javier Pérez Royo, Curso de Derecho Constitucional, Marcial Pons, $11^{a}$ ed., 2007, pp. 795-828.

182 Javier Pérez Royo, ob. cit., p. 119.
} 
"A interpretação da Lei é o reino da igualdade. A interpretação da Constituição é o reino do monopólio. Os indivíduos são iguais na interpretação da Lei porque assim o exige uma sociedade igualitária, na qual não pode haver relações de sujeição pessoal. Os indivíduos são iguais na interpretação da Constituição porque assim o exige um Estado que tem o monopólio do poder. No primeiro caso, os indivíduos interpretam livremente a lei, em pé de igualdade (....) No segundo, a interpretação é igual para todos, porque é feita igualmente para todos os cidadãos pelos dois órgãos que expressam o monopólio do poder estatal: o Parlamento, que tem o monopólio para fazer a lei, e o Tribunal Constitucional, que tem o monopólio do controle de constitucionalidade da lei. Interpretação da Lei e interpretação da Constituição refletem a vida da Sociedade Civil e do Estado Constitucional." ${ }^{, 183}$

Analisando especificamente a interpretação realizada pelo Tribunal Constitucional, verifica-se que ele também faz uso, eventualmente, da técnica originalista especialmente em relação aos debates parlamentares, aos quais recorre com frequiência, "mas nunca como critério suficiente para fundamentar a interpretação". 184

Esse diagnóstico é corroborado por Enrique Alonso García, que admite que o Tribunal, em várias ocasiões, examinou "com toda liberdade" os debates parlamentares, conferindo-lhes valor para o significado do termos da Constitiuição, ainda que em combinação com outras fontes. ${ }^{185}$

Os dois autores mencionam como exemplo a Sentença n. 5/1981, uma das primeiras proferidas pelo Tribunal, em 13.2.1981, na qual se afirmou que "os debates parlamentares (...) são um importante elemento de interpretação, ainda que não determinante"; no caso, esses debates ajudaram a firmar o entendimento de que a

\footnotetext{
${ }^{183}$ Pérez Royo, ob. cit., pp. 119-120.

${ }^{184}$ Pérez Royo, ob. cit., p 124.

185 Enrique Alonso García, La Interpretación de la Constitución, Madri, Centro de Estudios Constitucionales, 1984, pp. 148-151; Javier Pérez Royo, ob. cit., p. 124.
} 
liberdade de cátedra aplicava-se a professores de todos os níveis de ensino, e não apenas no nível superior ${ }^{186}$.

Com maior ênfase, a Sentença n. 12/1982 declarou que “as conseqüências a que chegamos nos tópicos anteriores, através de uma interpretação objetiva da Constituição, resultam corroboradas pela utilização dos critérios de interpretação derivados dos antecedentes e dos trabalhos preparatórios do texto constitucional". 187

Na Sentença 18/1982, a Corte identificou a intenção do constituinte quanto ao âmbito da "legislação" e da "execução" previstas no art. 149 da Constituição, com vistas à "regulação unitária" da matéria trabalhista, enquanto que em uma Sentença de 16 de novembro de 1981 os mesmos conceitos foram utilizados para anular legislação do governo regional basco a respeito do transporte terrestre de mercadorias. ${ }^{188}$

Diferentemente, porém, de Pérez Royo, Alonso García afirma que em pelo menos quatro casos, nos primeiros anos de atividade do Tribunal (escrevia ele em 1984), o argumento originalista foi "conclusivo" para a interpretação de conceitos da Constituição: o princípio do non bis in idem em matéria criminal; o tratamento da greve e dos conflitos coletivos; o conceito de "modificação" em matéria tributária e a possibilidade de criação de redes de televisão privadas. ${ }^{189}$

Assim, pois, na Sentença 2/1981, em relação à impossibilidade de dupla punição pela mesma conduta, tanto em âmbito criminal como na esfera administrativa, o Tribunal proclamou:

“ (....) ainda que não expressamente mencionado nos arts. 14 a 30 da Constituição, que reconhecem os direitos e liberdades suscetíveis de amparo (...), nem por isso cabe silenciar que, tal como entenderam os parlamentares na Comissão de Assuntos Constitucionais e Liberdade Públicas do Congresso, ao dele prescindir na redação do artigo

\footnotetext{
${ }^{186}$ Ob. cit., p. $151 . \mathrm{N}$

${ }^{187}$ A integra desta e das demais sentenças cujo número é aqui citado estão disponíveis no endereço eletrônico do Tribunal Constitucional da Espanha (www.tribunalconstitucional.es).

${ }^{188}$ Alonso García, ob. cit., pp. 149-150.

${ }^{189}$ Alonso García, ob. cit., pp. 148-149.
} 
9 do Anteprojeto de Constituição, está intimamente ligado aos princíopios de legalidade e tipicidade das infrações, colhidos especialmente no art. 25 da Constituição". ${ }^{190}$

$\mathrm{Na}$ Sentença n. 11/1981, para delimitar os distintos regimes de proteção do direito de greve e dos conflitos coletivos de trabalho, o Tribunal igualmente se apoiou na intenção dos constituintes, revelada pelo registro dos trabalhos parlamentares:

“(...) a tese de que o art. 37 reitera parcialmente o art. 28 não é, a nosso juízo, correta. Da ampla discussão de ambos os preceitos, no momento de elaboração do texto constitucional, se extrai sem dúvida a consequência de que o constituinte quis separar o direito de greve das demais possíveis medidas de conflito. (...) O primeiro deles, enquanto contido na Seção $1^{\mathrm{a}}$ do Capítulo Segundo, está garantido com a reserva de lei orgánica, admite a tutela dos tribunais ordinários em procedimento preferencial e sumário (...) e o recurso de amparo perante este Tribunal. Além disso o constituinte considerou a greve como um dos direitos fundamentais, enquanto que o direito de adoção de medidas de conflito não tem aquela categoría". ${ }^{191}$

\subsection{Portugal}

O Tribunal Constitucional Português não é um órgão do Poder Judiciário; criado na primeira revisão da Constituição portuguesa, em 1982, tem sua organização e competência previstas em título autônomo da Constituição, a denotar sua completa independência em relação aos demais poderes. É composto por treze juízes, com mandato não renovável de nove anos, sendo dez integrantes nomeados

\footnotetext{
${ }^{190}$ Primeira Sala do TC, j. 30.1.1981; juízes García-Pelayo, Latorre, Díez de Velasco, Begué, Gómez-
} Ferrer e Escudero.

${ }^{191}$ Pleno, 8.4.1981; participaram do julgamento os juízes García-Pelayo, Latorre, Díez de Velasco, Rubio Llorente, Begué, Díez-Picazo, Tomás, Gómez-Ferrer, Escudero, Fernández e Truyol. 
pela Assembléia da República e outros três por "cooptação" daqueles; seis juízes são escolhidos dentre os membros dos tribunais judiciários, e sete dentre juristas (CRP, art. 222). O Tribunal Constitucional exerce a fiscalização abstrata de constitucionalidade (tanto preventiva quanto repressivamente) e também a fiscalização concreta, uma vez que pode rever, mediante recurso, as decisões dos demais tribunais em matéria constitucional (CRP, arts. 277 a 283). ${ }^{192}$

A natureza política do Tribunal, a forma de recrutamento de seus integrantes e o sistema de mandatos conferem às suas decisões uma inquestionável legitimidade política, especialmente em matéria de interpretação constitucional. Além disso, a Constituição prevê sua própria reforma a cada período de cinco anos (art. 284), o que propicia sua constante atualização pelos canais democráticos.

Percebe-se, assim, que em Portugal não estão presentes as condições as condições gerais que, nos Estados Unidos, fizeram vicejar tanto o ativismo judicial como o seu mais drástico antídoto, o originalismo.

A confirmar esse raciocínio, colhemos em António de Araújo a informação de que, no Tribunal Constitucional português, nem mesmo havia se instalado, pelo menos até 1997, uma disputa entre ativismo e auto-contenção, embora em alguns casos possam ser encontradas "pistas num e noutro sentido". ${ }^{193}$ Uma das "pistas" citadas por esse autor é o voto vencido da Conselheira Maria da Assunção Neves no Acórdão 36/90, em que se defende que o Tribunal Constitucional, por respeito ao princípio democrático, não deve avaliar "o mérito da atividade parlamentar". Nos outros casos, a Conselheira chama "a atenção para os limites da jurisdição constitucional em face da discricionariedade do legislador" (acórdãos 364/91, 161/93 e 148/94).

Mesmo assim, eventualmente o Tribunal Constitucional português utiliza o enfoque originalista, assim como também o fizera a Comissão Constitucional que o antecedera.

\footnotetext{
192 V., a respeito do tema, Alexandre de Moraes, Jurisdição Constitucional e Tribunais Constitucionais, cit., pp. 177-207.

${ }^{193}$ O Tribunal Constitucional, Coimbra Editora, 1997, p. 159.
} 
Da jurisprudência da Comissão Constitucional (que funcionou de 1976 a 1982), encontramos o acórdão nº 166, de 12 de novembro de 1979, no qual, para bem delimitar o conceito de censura - proibida pela Constituição - recorreu-se à análise dos debates travados na Assembléia Constituinte.

Questionava-se, no caso, decisão do Supremo Tribunal de Justiça, que considerara inconstitucional acórdão do Tribunal da Relação de Lisboa, mandando riscar dos autos de um processo expressões utilizadas nas alegações de uma das partes, consideradas agressivas e "injuriosas para os órgãos do Poder que orientaram ou conduziram o processo de descolonização, isto é, o Presidente da República, o Governo e o Conselho da Revolução".

\section{Ponderou, então, a Comissão Constitucional:}

"Sobre esta matéria pronunciou-se o Deputado José Augusto Seabra, que referiu as formas diferenciadas por que se podem exercer os diversos tipos de censura: 'Pode ser uma censura prévia ou a posteriori. No regime salazarista, para a imprensa, existia o regime de censura prévia. Para as outras publicações, para os livros, por exemplo, a censura não era prévia, mas havia uma sanção a posteriori (... $)^{\prime}$. (....)

Pretendeu-se, assim, abranger na proibição constitucional não só os diversos tipos de censura - política, econômica e moral -, mas também as diversas formas de a exercer. E esclareceu-se que estas tanto podiam ser prévias como a posteriori.

Saliente-se que durante os debates não foi ignorada a questão da aplicação de sanções por via judicial. Por um lado, estas encontram-se previstas no n. 3 do artigo $37^{\circ}$; por outro lado, vários Deputados referiram-se a essa questão, em resposta ao Deputado Vital Moreira, que suscitou o problema de saber se a redacção adoptada para $\mathrm{o} \quad \mathrm{n}^{\mathrm{o}} 2$ não podia conduzir a uma interpretação que inconstitucionalizasse tais sanções.

Pese embora a falta de clareza do debate sobre esta precisa matéria, parece poder concluir-se que a intenção foi tão-só a de impedir a aplicação de sanções por via administrativa e de restringir as hipóteses de aplicação de sanções por via judicial aos 
casos em que se haja violado os limites constitucionalmente definidos ao direito de expressão e divulgação do pensamento."

Prosseguindo nessa linha, o acórdão ainda transcreveu pronunciamentos de outros três deputados (Mota Prego, Mário Mesquita e Vital Moreira), para então concluir:

"Não parece, pois, que o legislador constituinte tenha pretendido considerar como uma forma de censura os casos em que a lei prevê a aplicação de sanções pelos tribunais judiciais, em consequiência dos limites constitucionalmente impostos ao direito de expressão e divulgação do pensamento."

Com base nesse fundamento, a Comissão Constitucional revogou o acórdão do Supremo Tribunal de Justiça. ${ }^{194}$

Com relação à jurisprudência do Tribunal Constitucional (criado na primeira revisão constitucional, de 1982), selecionamos quatro exemplos. ${ }^{195}$

O primeiro é o acórdão n. 107/88, proferido em processo de fiscalização preventiva de constitucionalidade em face de decreto da Assembléia da República que autorizava o governo a rever o regime jurídico da cessação, suspensão e redução do contrato individual de trabalho, inclusive para estabelecer o alargamento do conceito de justa causa para despedida, do trabalhador.

Este último ponto foi contestado com base no art. 53 da Constituição, que prevê o direito à segurança no emprego. E para dirimir a questão, o Conselheiro o Monteiro Diniz, falando pela maioria, considerou necessária a "rigorosa captação do âmbito normativo" dos conceitos envolvidos. Para tanto, procedeu ao "recenseamento das fontes e das vicissitudes formativas" do mencionado dispositivo constitucional, examinando cada uma das propostas apresentadas na Assembléia Constituinte a respeito do direito ao trabalho e da segurança no emprego.

\footnotetext{
${ }^{194}$ A íntegra dessa decisão encontra-se em Jorge Miranda (ele próprio um dos subscritores do acórdão), Jurisprudência Constitucional Escolhida, vol. I, Lisboa, 1996, pp. 349-363.

${ }^{195}$ Textos disponíveis em www.tribunalconstitucional.pt/tc/home.html.
} 
A seguir, destacou a votação no plenário da Assembléia Constituinte, em 16 e 17 de setembro de 1975, do texto que estabelecia a proibição de “despedimento sem justa causa ou por motivos políticos ou ideológicos", tendo sido rejeitada a inclusão, após "justa causa", da expressão “ou por motivo atendível", que havia sido proposta pelo Partido Popular Democrático. Assim surgiu o art. 52, "b”, da redação original da Constituição, renumerado para 53, “b”, na revisão constitucional de 1982. Nessa ocasião, porém, o preceito mudou de capítulo, deixando de ser uma incumbência do Estado e passando a ser um direito dos trabalhadores.

Todo esse percurso, bem como os conceitos legais contemporâneos à elaboração da norma, minuciosamente descritos no voto, levaram o relator a concluir que a justa causa somente se configuraria quando presente "uma conduta culposa do trabalhador", e que assumisse gravidade compatível com uma “infracção disciplinar que não comporte a aplicação de outra sanção". E assinalou ainda, que "o texto constitucional não admite o renascimento da figura do despedimento com base em motivo atendível", pela simples e bastante razão de ter sido proposta e rejeitada sua inclusão.

O legislador, embora tendo "uma certa margem de configuração do conceito constitucional de justa causa", não poderia deixar de levar essas considerações e "transfigura seu conteúdo essencial", revelado pelo processo de elaboração da norma constitucional. Por permitir esse alargamento excessivo do conceito, o decreto impugnado foi julgado, nesse ponto, inconstitucional.

É digno de nota que, em declarações de votos vencidos nesse mesmo acórdão, os Conselheiros Raul Mateus e Messias Bento também fizeram longas explanações sobre os trabalhos preparatórios e debates no âmbito da Assembléia Constituinte, deles extraindo, porém, a conclusões diversas das que foram adotadas pela maioria.

Um segundo exemplo é o acórdão n. 148/07, proferido em 2 de março de 2007, em que o Tribunal foi chamado a decidir, em grau de recurso, se os membros vogais do Conselho Superior dos Tribunais Administrativos e Fiscais, por terem asseguradas as mesmas garantias dos juízes, conforme expressamente previsto no 
Estatuto dos Magistrados Judiciais (art. 148, n. 1), também teriam, em decorrência, as mesmas vedações e incompatibilidades dos magistrados (e por isso estariam proibidos de advogar).

A interpretação contrária era questionada em face dos artigos da Constituição portuguesa estabelecendo os princípios da independência dos tribunais (art. 203), da igualdade (art. 13) e o direito a um processo equitativo (art. 20, n. 4).

Para decidir a controvérsia, o Tribunal Constitucional ponderou que a redação do art. 223, após a revisão de 1982, passou a aplicar aos membros do Conselho Superior da Magistratura as mesmas garantias e incompatibilidades dos juízes. Porém, na revisão constitucional seguinte, em 1989, a aplicação dessas incompatibilidades foi retirada, passando então o texto a referir-se apenas às garantias.

Para esclarecer o fundamento dessa modificação, o relator do Acórdão, Conselheiro Vitor Gomes, fez longa citação dos trabalhos preparatórios no âmbito da assembléia revisora, de modo a comprovar a intenção do constituinte:

"O propósito do legislador constituinte é claramente assumido nas seguintes passagens das actas da Comissão Especial da Revisão Constitucional (CERC) quando no seu seio se discutiu a proposta de revisão de que emergiu (Diário da Assembleia da República, II Série, n. ${ }^{\circ}$ 49-RC, de 22 de Outubro de 1988) e de que veio a resultar a aprovação do texto que actualmente constitui o $\mathrm{n}^{\circ} 2$ do artigo $218 .^{\circ}$ :

O Sr. José Magalhães (PCP):- Sr. Presidente, esta proposta é relevante, e é-o para resolver um problema que está pendente desde há longos meses e que foi suscitado por todos nós ao aprovarmos o Estatuto dos Magistrados Judiciais.

Se a Constituição estabelece que são aplicáveis a todos os vogais, incluindo os eleitos pela Assembleia da República, as regras sobre as incompatibilidades, então está suscitada uma questão melindrosíssima. A lei actual não tem isso em conta, a lei actual «liberta» dessa incompatibilidade alguns dos membros do Conselho. E nós, ponderando a situação criada, entendemos que pode ter justificação uma certa diferenciação. De facto, pode justificar-se que 
vigore um regime diferente de incompatibilidades para os elementos eleitos pela Assembleia da República. Mais franca e directamente, está aqui em causa a constitucionalização do actual Estatuto dos Magistrados Judiciais, sob pena de se abrir uma melindrosa questão, que pode passar, um dia destes, por algum accionamento do sistema adequado e pela correspondente jurisprudência. Cremos que, numa matéria deste melindre, a solução deveria ser expedita e certeira, para podermos tirar todas as ilações, sob pena de alguma hipocrisia na manutenção de um status contrário à Constituição, por debilidade ou má confecção da correspondente norma constitucional.

Creio que hoje, após alguns anos de vigência do Conselho Superior da Magistratura e de um juízo já possível sobre a importância dos elementos eleitos pela Assembleia da República, estabelecer uma diferenciação é já só uma questão de bom senso. Espero, portanto, que seja também uma questão de consenso.

O Sr. Vera Jardim (PS): (...)

É evidente que sobre as incompatibilidades - há pouco o Sr. Deputado José Magalhães interveio nesse sentido - o estatuto não contém uma regra deste teor. Teremos de estar atentos a esse aspecto, visto que, se não retirarmos isto, corremos o risco de não poder dignificar o Conselho Superior da Magistratura com várias categorias (professores de Direito, advogados, etc.), que, evidentemente, não aceitarão ser eleitos ou designados pelo Presidente da República. Foi por isso mesmo que há pouco tentei interromper o Sr. Deputado José Magalhães, para ver se ele não estaria também de acordo que os dois não magistrados designados pelo Presidente da República (na nossa versão), ou um (na versão actual da Constituição), fossem também isentos dessas incompatibilidades, que ficariam apenas para os magistrados, pois, em matéria de vencimentos, sabemos que o magistrado continua com o seu vencimento, ao passo que exigir a um advogado, a um professor de Direito ou a um jurisconsulto que vá para o Conselho Superior da Magistratura em condições deste tipo não terá, evidentemente, acolhimento por parte daqueles. (...)

O Sr. Presidente: (....)

A terceira questão respeita ao problema de estender aos membros do Conselho Superior da Magistratura os direitos e garantias 
e também as incompatibilidades de que gozam os magistrados enquanto vogais do órgão citado.

Admitimos que a redacção dada ao artigo $223 .^{\circ}$ pelo $P S D$ possa ir demasiado longe no sentido de que poderá haver alguns aspectos, designadamente em matéria de incompatibilidades, que, eventualmente, possam ser um pouco mais restringidos, desde que não seja funcionalmente exigível para a garantia da sua imparcialidade, àqueles que não forem membros do conselho permanente, Daí que esta matéria, que foi, aliás focada pelo PS, pudesse justificar uma redacção mais restritiva, porque reconhecemos que pode ser difícil a um professor de Direito ou a um advogado ser membro do Conselho Superior da Magistratura, em termos de satisfazer plenamente todas as regras relativas às incompatibilidades que vigoram para os juízes. Porém, com esta ressalva parece-nos que é importante que o cargo de membro do Conselho Superior da Magistratura seja suficientemente salvaguardado para garantir a sua independência."

Como o dispositivo questionado, do Estatuto dos Magistrados Judiciais, passou a ter a mesma redação do art. 223, n. 2 da Constituição, e havia sido editado "para resolver ao mesmo problema", o Tribunal Constitucional rejeitou a arguição de inconstitucionalidade e reconheceu aos advogados indicados para o citado Conselho Superior o direito de continuar exercendo sua profissão.

O terceiro caso que trazemos à baila é o acórdão n. 743/96, de 28 de maio de 1996 (1 ${ }^{\mathrm{a}}$. Seção, rel. Cons. Monteiro Diniz), em que foi declarada a inconstitucionalidade do art. $2^{\circ}$ do Código Civil, na parte em que autorizava os tribunais a fixar teses com "força obrigatória geral". Manifestando reverência à intenção do legislador ordinário, o Tribunal Constitucional utilizou, como uma das razões de decidir, a exposição de motivos do Decreto-lei n. 329/95, que ainda não entrara em vigor, indicando o propósito de extinguir os assentos judiciais com força de lei.

O quarto e último exemplo que selecionamos é o acórdão n. 399/10, proferido em 27 de outubro de 2010, em que se analisava a constitucionalidade de um dispositivo do "Código do Imposto sobre o Rendimento da 
Pessoas Singulares", estando em causa a proibição de retroatividade das leis tributárias (CRP, art. 103, n. 3). Para esclarecer o alcance dessa proibição, o plenário do Tribunal considerou "particularmente elucidativos" os "trabalhos preparatórios da IV Revisão Constitucional".

Após transcrever cada uma das propostas apresentadas pelos diversos partidos políticos, o voto da relatora, Conselheira Ana Guerra Martins, reportou-se aos debates ocorridos na Assembléia, resumindo-os nos seguintes termos:

“1. $\left.{ }^{\circ}\right)$ Verificou-se um certo consenso no sentido da consagração da proibição da retroactividade pura e simples da lei fiscal, como o demonstram, em especial, as intervenções dos Deputados José Magalhães, Octávio Teixeira e Maria Eduarda Azevedo. Assim, logo na sua primeira intervenção, a propósito do actual n. ${ }^{\circ} 3$ do artigo $103 .{ }^{\circ}$ CRP, o Deputado José Magalhães afirma que "(... há um consenso inicial no sentido de se clarificar este ponto, objecto de abundante controvérsia doutrinal e jurisprudencial (...)". No mesmo sentido se expressou o Deputado Octávio Teixeira: "em relação a esta questão da retroactividade (...), o que nos interessa fundamentalmente é constitucionalizar o princípio da não retroactividade". A Deputada Maria Eduarda Azevedo assevera mesmo que "estamos todos na mesma linha quanto às propostas apresentadas" (cfr. DAR, II Série, RC, n. ${ }^{\circ}$ 36, de 10 de Outubro de 1996, p. 1081 e segs).

2. $\left.{ }^{\circ}\right)$ A retroactividade só é proibida para as leis que criem ou aumentem impostos e não para as que diminuam ou eliminem impostos.

3. ${ }^{\circ}$ ) Não se pretendeu abranger as situações - que, aliás, ocorrem, frequentemente, nos Orçamentos - de alteração de taxas sobre rendimentos do ano anterior no que diz respeito aos impostos sobre o rendimento, como é caso do IRS. A primeira intervenção neste sentido coube a José Magalhães: “a nossa formulação (...) visa clarificar (...) o que é e o que não é retroactividade, designadamente salvaguardar, como é evidente, o princípio de que as normas respeitantes a impostos directos que incidem sobre os rendimentos do ano anterior não devem 
ter efeitos retroactivos. Obviamente sempre assim terá de ser." (cfr. DAR, II Série, RC, n. ${ }^{\circ}$ 36, de 10 de Outubro de 1996, p. 1081 e segs). Também a intervenção do Deputado Octávio Teixeira corrobora este entendimento: “(...) quando da primeira leitura, todos os partidos políticos presentes nesta Comissão disseram que não queriam confundir o seguinte: quando nos Orçamentos para o ano $X$ ou para o ano $N$ se alteram, por exemplo, as taxas, as deduções, os abatimentos, ou o que quer que seja aos impostos sobre os rendimentos - quer o IRS quer o IRC - essas alterações aplicam-se aos rendimentos do ano $N$ menos I" (cfr. DAR, II Série- RC, n. ${ }^{\circ}$ 99, de 4 de Junho de 1997, p. 2920 e segs.).

4. $\left.{ }^{\circ}\right)$ O escopo da norma era o de impedir a criação de impostos extraordinários, como o que tinha ocorrido em 1983 (imposto extraordinário) e não se deveria estender, nos casos dos impostos directos, como o IRS e o IRC, à possibilidade de alterar as taxas sobre rendimentos do ano anterior (cfr., de novo, a intervenção do Deputados Octávio Teixeira, in DAR, II Série- RC, n. ${ }^{\circ}$ 99, de 4 de Junho de 1997, p. 2920 e segs.).

Após essa extensa e minuciosa transcrição, em que constam inclusive as intervenções individuais de deputados, a Conselheira relatora acompanhada pela ampla maioria do Tribunal - concluiu que "dos trabalhos preparatórios da revisão constitucional de 1997 retira-se, por um lado, que o legislador da revisão apenas pretendeu incluir, no $n .^{\circ} 3$ do artigo $103 .^{\circ}$ da CRP, a proibição da retroactividade autêntica, própria ou perfeita da lei fiscal"; assinalando um pouco adiante que "resulta igualmente dos trabalhos preparatórios, de forma cristalina, que não se pretenderam integrar no preceito as situações em que o facto tributário que a lei nova pretende regular não ocorreu totalmente ao abrigo da lei antiga, antes continuando a formar-se na vigência da lei nova, pelo menos, quando estão em causa impostos directos relativos ao rendimento”.

Ficou assim patente que também nesse caso o Tribunal emprestou autoridade conclusiva à intenção dos constituintes, conforme registrada nas atas dos respectivos trabalhos. 


\subsection{Argentina}

\subsubsection{A coexistência de múltiplos critérios}

A Constituição Argentina, promulgada em $1853^{196}$ após a reunião do Congresso Geral Constituinte em Santa Fé, instituiu a Corte Suprema de Justiça como órgão máximo do Poder Judiciário (art. 108), atribuindo-lhe a função de conhecer e decidir "todas as causas que versem sobre pontos regidos pela Constituição" (art. 116).

Ao longo de quase cento e cinquenta anos de atividade - pois entrou em efetivo funcionamento apenas em 1863 - a Corte Suprema vem adotando, não raro simultaneamente, uma ampla variedade de critérios interpretativos.

Assim, ora considera suficiente a interpretação literal (Fallos $324: 1740,3143,3345^{197}$ ), ora propõe afastar-se do texto escrito, buscando aproximar-se mais dos ideais de justiça (Fallos 315:158) ou das verdadeiras intenções do legislador (Fallos 323:212, 3139). Por vezes a Corte prefere a interpretação dita especializada, de acordo com o sentido técnico-legal das palavras (Fallos 320:2319), enquanto que em outras oportunidades procura aproximar-se do entendimento que as pessoas comuns teriam do texto (Fallos 324:3345). Em alguns casos é enaltecido o valor dos precedentes (a chamada interpretação continuísta - Fallos 323:555), ao passo que em outros se admite sem maiores dificuldades a revisão daqueles (Fallos 317:312). E vários outros critérios são por vezes adotados, sem grande preocupação com a coerência ou a previsibilidade das decisões. ${ }^{198}$

\footnotetext{
${ }^{196} \mathrm{O}$ texto original sofreu diversas reformas, sendo que as principais ocorreram em 1949, $1955 \mathrm{e}$ 1994.

${ }^{197}$ Os textos e ementas dos julgamentos (fallos) mencionados neste item foram obtidos no endereço eletrônico da Suprema Corte, especificamente nos arquivos da Secretaria de Jurisprudência (http://www.csjn.gov.ar/jurisprudencia.html).

${ }^{198}$ Néstor Saguiés, La Interpretación Judicial de la Constitución, 2006.
} 
Não é sem razão que Roberto Gargarella critica esse "permanente, despreocupado ir e vir entre critérios interpretativos que apontam em direções muitas vezes opostas". 199

\subsubsection{A interpretação voluntarista}

É certo, todavia, que em meio a esse "arsenal impressionante" de métodos, um dos mais recorrentes consiste na chamada interpretação voluntarista, que “consiste em respeitar a vontade do legislador, pois é missão dos juízes dar pleno efeito às normas vigentes, sem substituir-se a este, e sem julgar quanto ao acerto ou conveniência das disposições adotadas por ele". ${ }^{200}$

Em outra obra, Néstor Sagüés reitera que esse enfoque voluntarista é majoritário, salientando que "as pautas jurisprudenciais do alto Tribunal em favor da interpretação histórica são abundantes”. Cita, nesse sentido, o julgamento no caso Ferrocarril de Buenos Aires (Fallos 111:334 e 367), em que se assentou que “o espírito da lei, ou seja, a intenção do legislador, deve ser determinado quando, fora do texto da norma, conste de forma clara e evidente, se assim surge da exposição de motivos"; ou, ainda, o caso Piccardo, em que a Corte proclamou que "o fim primordial do intérprete é dar pleno efeito à vontade do legislador". ${ }^{201}$

Em outros julgamentos, a Corte Suprema novamente considerou a exposição de motivos de uma lei como "um valioso critério interpretativo quanto à intenção de seus autores" (Fallos 316:1793, 318:1894, 319:2617), recorrendo, com a

\footnotetext{
${ }^{199}$ Roberto Garagarella, De la alquimia interpretativa al maltrato constitucional, in Teoria y Crítica del Derecho Constitucional, 2009, p. 236.

${ }^{200}$ Sagüés, ob. cit., p. 149, transcrevendo trecho de julgamento da Suprema Corte (Fallos 323:2117) e vários precedentes no mesmo sentido (Fallos 302:973, 304:1007, 305:538, 308:1745). A estes podem ser acrescentados os Fallos 182:486 e 184:5, além de outros, referidos mais adiante.

201 Sagués, Derecho Procesal Constitucional - Recurso Extraordinário (t. 2), 2002, pp. 21-22. Digno de nota que, neste e em numerosos outros casos - Fallos 150:160, 200:176, 210:541, 307:480, 307: 1018, 315:38, 315:262, 315:1992, 315:2443, 320:1962, entre muitos outros - a Suprema Corte considera as expressões "vontade do legislador" e "espírito da lei" como sinônimas, tratando como muito próximos, senão idênticos, em matéria de interpretação, os enfoques histórico, voluntarista e finalístico.
} 
mesma finalidade, aos registros dos debates parlamentares (Fallos 210:541, 211:168, 313:1333).

No caso Martínez c/ Caja de Jubilaciones de La Marina Mercante, de 1944, a diretriz foi reiterada, mas com importante acréscimo que aponta em direção ao entendimento original do texto normativo, conforme constou da ementa:

"O fim primordial do intérprete é dar pleno efeito à vontade do legislador, e a primeira fonte de interpretação da lei são suas palavras, que devem ser entendidas como empregadas no verdadeiro sentido que têm na vida diária, partindo do princípio de que não são supérfluas e foram empregadas com algum propósito, seja de ampliar, limitar ou corrigir os conceitos". ${ }^{202}$

Três décadas depois, o Tribunal continuava mantendo esse entendimento, mas agora pondo em relevo a necessidade de buscar a harmonização do preceito legal com o conjunto do ordenamento, sob o influxo dos princípios maiores da Constituição:

"A primeira regra de interpretação das leis é dar pleno efeito à intenção do legislador, computando a totalidade de seus preceitos de maneira a harmonizá-los com o restante do ordenamento jurídico e com os princípios e garantias da Constituição Nacional”. ${ }^{203}$

Em 1989, ao decidir o caso Província del Neuquen v. Hidronor, a Corte Suprema novamente invocou "uma doutrina já consolidada na jurisprudência do Tribunal, que afirma que é missão do intérprete indagar o verdadeiro sentido e

${ }^{202}$ Fallos 200:165 (o destaque é nosso). Os textos e ementas dos julgamentos mencionados neste item foram obtidos no endereço eletrônico da Suprema Corte, especificamente nos arquivos da Secretaria de Jurisprudência (http://www.csjn.gov.ar/jurisprudencia.html).

${ }^{203}$ Fallos: 281:146 (1971). 
alcance da lei mediante um exame atento e profundo de seus termos que atenda à realidade do preceito e à vontade do legislador" 204.

Em sua atual composição, a Corte reafirmou que "em definitivo, o fim primordial do intérprete é dar pleno efeito à vontade do legislador", ${ }^{205}$

\subsubsection{Vontade do legislador e interpretação constitucional}

Embora aplicada mais comumente à análise de textos legais, o enfoque histórico ou voluntarista também é observado ao longo da jurisprudência da Corte Suprema em matéria de interpretação constitucional. ${ }^{206}$

Roberto Gargarella, mesmo deplorando o "olhar originalista", que considera "pobre" ${ }^{207}$, reconhece que ele foi predominante na leitura que a Corte Suprema fazia da Constituição nas primeiras décadas do século XX, período da assim chamada "jurisprudência Bermejo". 208

Exemplo dessa tendência pode ser encontrado no emblemático caso Hileret, de 1903. Estava em causa uma lei da província de Tucumán criando um imposto progressivo sobre a produção de açúcar. Até uma determinada quantidade, o imposto seria bastante módico, mas o excedente a esse limite seria pesadamente taxado. O objetivo almejado pela norma era salvar da ruína os pequenos produtores, garantindo-lhes o escoamento de sua produção.

\footnotetext{
${ }^{204}$ Fallos 312:2177 (o destaque é nosso); o acórdão invoca, nesse exato trecho, outros julgamentos no mesmo sentido (Fallos 291:359, 302:973, 307:146, 1487).

${ }^{205}$ Caso Astra v. YPF, 18 de novembro de 2008 (Fallos 331:2550).

${ }^{206}$ Data de 1864 o primeiro caso em que a Corte Suprema assumiu a condição de intérprete final da Constituição (caso Ministerio Fiscal c/Benjamín Calvete (Fallos, 1:340), e de 1888 a primeira vez em que declarou a inconstitucionalidade de uma lei (Capital v. Elortondo, Fallos 33:162).

${ }^{207}$ Roberto Gargarella, El artículo 22 y el proyecto de uma comunidad de iguales (palestra na Universidade de Buenos Aires, maio de 2010; disponível em http://igualitaria.org/una-constitucionpara-el-nuevo-siglo).

${ }^{208}$ Antonio Bermejo foi um dos mais influentes juízes da Corte Suprema em toda a sua história; integrando-a desde 1903, foi seu presidente de 1905 até o seu falecimento, em 1929.
} 
A questão foi posta pelo Tribunal nos seguintes termos: as garantias constitucionais, especialmente no que se refere à igualdade e à proteção da propriedade, seriam oponíveis somente ao legislador federal, ou também aos legislativos provinciais? Para proclamar esta última opção, invocou-se o entendimento original, prevalecente à época da elaboração da Constituição, como se pode ver do seguinte trecho, extraído do considerando n. 15 do julgado:

“15. Que há erro em atribuir às declarações e garantias contidas na primeira parte, capítulo da Constituição, o alcance de restringir apenas os poderes públicos nacionais, sob a influência de teorias e precedentes que não estão em harmonia (...) com as necessidades e anseios da época em que se redigiu [a Constituição] e com a inteligência que a ela se deu em documentos históricos e numerosas decisões judiciais. Deixando-se de lado outros, bastaria a esse respeito recordar o informe da comissão encarregada de formular um projeto de Constituição, na primeira Convenção Nacional de Santa Fé. A comissão, conforme consta desse informe, preocupou-se especialmente com a resolução deste problema: como fazer que o governo federal proporcione à Nação respeito e boa reputação no exterior, paz interna, desenvolvimento do comércio, da indústria e da população? A comissão acreditou tê-lo resolvido pelos meios consagradas nas declarações [de direitos] e garantias. Nossa situação é dolorosa, porque retrógrada. É preciso que a prática do regime constitucional a que aspiramos proporcione, ao menos aos que nos sucederem, segurança à vida e às propriedades, meios de trabalho, preço [justo] às nossas terras e produtos e facilidades para o comércio com os povos estrangeiros, de cujos produtos e tecnologias carecemos... Por último, o projeto que se tem a honra de submeter a exame (...) não é obra exclusivamente da comissão. É a obra do pensamento argentino, manifestado por seus publicistas... (Congresso Geral Constituinte de Santa Fé, sessão de 18/4/1953)". 209

${ }^{209}$ Fallos 98:20 (os destaques são nossos). 
A seguir, nos itens 16 e 17, recorre-se ainda às atas do Congresso Constituinte para ressaltar que entre os "publicistas" citados no item anterior encontrava-se Alberdi, em cujo projeto de Constituição já se encontravam redigidos os artigos sob exame, reunidos sob a epígrafe "Direito Público Argentino". Isto era suficiente para demonstrar - assim considerou a Corte - que tais dispositivos seriam aplicáveis não só em relação ao governo central, mas também às províncias (dito de outro modo, tratava-se de direito "nacional" e não apenas "federal"), concluindo-se então:

"17. Que Alberdi, que tomou como modelos para essa parte de seu projeto as Constituições de Massachussets e da Califórnia - ou seja, de comunidades políticas em que não funcionavam duas Administrações Públicas independentes (Bases XI e XXXVI) - entendia que 'garantias privadas do homem e do cidadão, são as mesmas na província e na Nação: toda autoridade local ou geral deve igualmente dar-lhes amparo e proteção', sustentando, por sua vez, a conveniência de celebrar tratados com nações estrangeiras para reforçar ainda mais essas garantias - Bases, $\S \mathrm{XV}$, Elementos de Direito Público Provincial Argentino, ed. 1856, p. 252 e 258)....”.

Embora seja inegável o viés conservador em tal decisão, algo semelhante ao caso Lochner, da Suprema Corte norteamericana - pois aqui também se rejeitou a intervenção do Estado na atividade econômica, com fundamento na proteção constitucional ao direito de propriedade - por outro não se pode deixar de observar que o Tribunal não se curvou à "lógica da emergência" (diríamos hoje: "razões de Estado"), que pretendia por de lado o regime de legalidade em situações de crise. ${ }^{210}$

\footnotetext{
${ }^{210}$ Nesse sentido, Horácio Ricardo González, Los derechos fundamentales y la emergência en Argentina, 2003.
} 
Poucos anos depois, ao julgar o caso Gorostiaga c/Aguilera, em 1911 - em que era questionado se a competencia da Justiça Federal para julgar delitos cometidos por deputados, a teor do art. 32 da Constituição, estendia-se aos crimes contra eles cometidos, por meio da imprensa -, a Corte Suprema fundamentou sua decisão nos debates havidos no Congresso de Santa Fé. ${ }^{211}$

O juiz Bermejo era partidário, por sinal, de um tipo bastante ortodoxo de orinalismo, que Bidart Campos denomina "interpretação estática": para ele, o que a Constituição "significava ao ser adotada, significa agora e continuará significando enquanto não seja reformada". ${ }^{212}$

A partir de 1934 a Suprema Corte adota uma linha interpretativa mais dinâmica, adaptando a Constituição às circunstâncias supervenientes ${ }^{213}$. Todavia, como aponta Sagüés, em vários julgamentos o tribunal continua a emprestar relevância à interpretação "autêntica" da Constituição, salientando a necessidade de atentar para os seus "antecedentes", que a fazem "impregnada de realidade argentina"214. Ainda no recente caso "Chocobar", por exemplo, serviram como fundamento os debates ocorridos durante a Constituinte reformadora de $1957^{215}$.

\footnotetext{
${ }^{211}$ Fallos 115:177.
}

${ }^{212}$ Voto vencido no caso Ercolano v. Renshaw, 1922 (Fallos 136:181), também citado por Bidart Campos, La Corte Suprema, 2010, p. 47.

${ }^{213}$ Bidart Campos, La Corte Suprema, p. 47.

${ }^{214}$ La Interpretación Judicial de la Constitución, cit., p. 153. Faz-se referência aos Fallos 316:2624, 178:9, 308:2268 e 313:1513.

215 Fallos 319:3264; Sagüés, La Interpretación Judicial de la Constitución, p. 150. A íntegra desse acórdão também pode ser encontrada no sítio www.dipublico.com.ar. 


\subsubsection{Abordagem originalista na doutrina}

Também na doutrina constitucional argentina não são incomuns análises de cunho originalista.

Néstor Sagüés, em obra recente ${ }^{216}$, várias vezes transcreve manifestações de constituintes - e até do "Projeto Alberdi", de 1852 - para alicerçar suas posições acerca de institutos processuais de controle de constitucionalidade e defesa de direitos fundamentais; assim, por exemplo, em aspectos relativos ao amparo $^{217}$, ao habeas data ${ }^{218}$ e ao habeas corpus ${ }^{219}$.

Outro bom exemplo nesse sentido é o estudo feito por Juan Ignácio Sáenz a respeito de duas históricas decisões da Câmara de Deputados, rejeitando dar posse a candidatos eleitos (Antonio Bussi, em 2000, e Luís Patti, em 2006), em razão terem sido processados criminalmente por envolvimento na repressão política na década de 1970. Embora nenhum dos dois, àquela altura, tivesse contra si uma condenação judicial, a Câmara negou-lhes a posse por "inidoneidade ética", com fundamento no art. 94 da Constituição Argentina, que confere a cada uma das casas do Parlamento a função de "juiz das eleições, direitos e títulos de seus membros”.

Embora as rejeições tenham, na prática, prevalecido ${ }^{220}$, Ignácio Sáenz sustenta que a Câmara excedeu seus poderes ${ }^{221}$, a partir de uma análise quanto ao

\footnotetext{
${ }^{216}$ Compendio de derecho procesal constitucional, Buenos Aires, ed. Astrea, 2009.

${ }^{217}$ Compendio, cit., $\$ \S 454-459$ e, especialmente, $\$ \S 483$ e 517.

${ }^{218}$ Compendio, cit., $\$ \S 682,686,687$ e, especialmente, $\S 688$.

${ }^{219}$ Compendio, cit., $\$ \S 712,714,716,719,721,722$.

220 Antonio Bussi conseguiu a declaração de invalidade da decisão da Câmara de Deputados, mediante ordem de amparo concedida pela Câmara Nacional Eleitoral em 2004, confirmada pela Suprema Corte em 2007. A ordem, todavia, somente veio quando a legislatura para a qual havia sido eleito já se encerrara. Importa anotar que, em 2008, foi ele afinal condenado criminalmente pela Justiça Federal de Buenos Aires por delitos contra a humanidade.

${ }^{221}$ Comentando o art. 94 da Constituição argentina, Bidart Campos também sustenta - embora sem aludir à gênese da norma - que não cabe à Câmara analisar "se o eleito reúne as condições constitucionais", sugerindo inclusive que essa atribuição fosse suprimida, já que "as Câmaras, diremos com Montes de Oca, são os piores juízes" (El Derecho Constitucional del Poder, 1967, t. I, pp. 248-249).
} 
dispositivo da Constituição estadunidense (art. I, seção V) que serviu de modelo ao art. 64 da Constituição argentina, nos seguintes termos:

"Desde um ponto de vista originalista, tendo em conta o sentido histórico que o parágrafo reproduzido foi inserido na Constituição, as Câmaras careceriam de uma atribuição como a exercida nos casos mencionados, pois o objetivo da Constituição, ao estabelecer tal dispositivo, era impor uma instância de revisão final no Congresso da Nação das eleições de deputados e senadores, desenvolvidas no âmbito local das províncias, distante do governo federal, e a respeito do qual os apoiadores do regime federal mantinham grande desconfiança e temor, pela ameaça que os interesses locais continuavam a representar para o êxito da Constituição e a efetiva organização e supremacia das autoridades nacionais.

Nos Estados Unidos, a mencionada competência para escrutinar os títulos dos legisladores eleitos nos Estados significou um mecanismo fundamental de controle por parte do governo federal (....)

Portanto, a condição de 'juiz' das 'eleições, direitos e títulos' instituída pelo art. 64 da Constituição para cada Câmara do Congresso deriva de disposição similar contida na Constituição dos Estados Unidos e foi inspirada em idênticos propósitos. (....)

A Câmara dos Deputados, ao utilizar a atribuição conferida pelo art. 64 para 'julgar' subjetivamente a 'idoneidade moral' de um legislador eleito regularmente, incorre em uma distorção patente de suas atribuições (...) o que contradiz a finalidade da citada cláusula constitucional, altera a distribuição de competências prescritas pela Constituição e, o que talvez seja mais grave, intervém no sufrágio popular, modificando o resultado de uma eleição e substituindo a vontade do eleitorado, o que é contrário ao princípio elementar da soberania do povo, expressamente mencionado no art. 33 da Constituição Nacional."222

\footnotetext{
${ }^{222}$ Juan Ignácio Sáens, Los Casos "Bussi" y "Patti": uma cláusula anacrônica en la Constitución y la Alteración Del Proceso Democrático, in Teoría y Crítica del Derecho Constitucional, 2009, t. 2, pp. 1279-1285.
} 
Outro caso em que a doutrina recorreu a argumentos da mesma inspiração encontra-se em artigo de Romina Faerman ${ }^{223}$, professora das universidades de Buenos Aires e Palermo, a respeito da constitucionalidade do artigo 86 do Código Penal argentino, que - à semelhança do congênere brasileiro - estabelece a descriminalização do aborto nas seguintes hipóteses: I - se não há outros meios para evitar perigo à vida ou à saúde da mãe; II - se a gravidez decorre de estupro ou outro delito de natureza sexual, na hipótese de demência da vítima.

Com base no art. 4.1 da Convenção Americana dos Direitos Humanos (incorporada ao ordenamento argentino), que prevê a proteção do direito à vida "em geral, a partir do momento da concepção", e no art. 75, item 23 da Constituição argentina, que determina o estabelecimento de um regime de seguridade social "em proteção à criança em situação de desamparo, desde a gravidez até o término do ensino fundamental", houve diversos pronunciamentos no sentido da inconstitucionalidade daquele dispositivo do Código Penal. ${ }^{224}$

Para defender a validade deste último, seja em face da Convenção Americana, seja à luz da Constituição, a articulista invoca, dentre outros, dois argumentos de nítido caráter originalista.

Quanto àquele tratado internacional, Romina Faerman investiga a gênese do citado art. 4.1:

"Segundo explica a Comissão Interamericana de Direitos Humanos no caso 'Baby Boy', a expressão 'em geral' foi incorporada para que a proteção do direito à vida seja compatível com as normas dos distintos países que despenalizam o aborto em algumas hipóteses específicas.

${ }^{223}$ Romina Faerman, Algunos debates constitucionales sobre el aborto, in Teoría y Crítica del Derecho Constitucional, 2009, t. 2, pp. 660-

${ }^{224}$ Romina Faerman menciona, nesse sentido, um voto vencido do juiz Pettigiani, da Suprema Corte de Buenos Aires, em julgamento ocorrido em 2005. 
Neste caso, a Comissão analisou o alcance do direito à vida reconhecido pela Declaração Americana dos Direitos e Deveres do Homem. A Declaração mencionada propunha originalmente o direito à vida desde a concepção. No entanto, esse artigo mereceu objeções por parte de diversas delegações, entre elas a argentina. As observações eram motivadas no conflito entre as leis desses Estados que despenalizavam o aborto em algumas hipóteses e o texto proposto. Por estas razões, o art. $1^{\circ}$. da Declaração foi aprovado pela Comissão deixando de fora a proteção da vida desde a concepção.

Estes antecedentes foram fundamentais para a redação do art. $4^{\circ}$. da Convenção Americana sobre Direitos Humanos. Neste caso, também se propôs inicialmente uma norma que garantia a proteção absoluta da vida desde a concepção, e foi reformada pelos mesmos motivos. Submetido a estudos, o projeto original mereceu iguais críticas às já mencionadas, e foi por isso que foi incorporada a expressão 'em geral' ".

O mesmo raciocínio é por ela invocado em relação à exegese do art. 75, n. 23 da Constituição argentina, pois "a intenção do constituinte parece abonar esta postura, dado que na Convenção Constituinte ${ }^{225}$ se ocuparam especialmente de esclarecer o alcance da norma, afirmando que nada diz em relação à proibição ou permissão do aborto". Transcreve, em seguida, trecho da intervenção do Senador Raúl Alfonsín nos debates da mencionada Convenção, expressando a posição de seu bloco partidário:

"A cláusula que estamos considerando foi o resultado de extensas conversações e intercâmbios de idéias que, em algum momento, mesclaram-se com projetos que estabeleciam critérios vinculados ao tema da vida e, outros, com relação ao aborto, tema que nosso bloco considerou que não se encontra habilitado para a consideração desta Convenção, tal como se pronunciou - segundo entendo - a Comissão de Redação, quanto à fixação de sua criminalização. Entendemos que era e é uma questão de tipo penal.

${ }^{225}$ A referência é à assembléia reformadora de 1994. 
Portanto vamos votar afirmativamente a proposta em consideração, porque está vinculado com o regime de seguridade de que a Argentina carece. (....) Por isso estamos de acordo a votar afirmativamente este projeto, que não diz ao Legislativo que penalize o aborto ou que libere qualquer possibilidade de aborto, mas que trata de uma iniciativa que poderia estar perfeitamente vinculada à legislação de um país que aceita o aborto, como a Suécia, como também à de um país como a Irlanda, que o proíbe". 226

\subsubsection{Tentativas de síntese}

A grande variedade de critérios interpretativos chancelados pela Corte Suprema suscita, evidentemente, a indagação quanto à possibilidade de uma síntese entre eles, de molde a evitar o perigo da desorientação e da insegurança dos aplicadores do direito.

No que diz respeito à interpretação e aplicação das normas em geral - mas em raciocínio que pode ser aproveitado, com as devidas adaptações, à interpretação constitucional - mencionaremos a solução preconizada por Ricardo Lorenzetti, atual presidente da Suprema Corte da Argentina.

Se, como tantas vezes reafirmado, "a primeira regra de interpretação é dar pleno efeito à vontade do legislador", a Corte também aponta ser necessário "verificar a razoabilidade da inteligência de uma norma", mediante "a consideração das suas conseqüências”. Vale dizer: a tarefa do juiz não se encerra com a interpretação do texto, mas deve prosseguir com a ponderação dos efeitos que dela advirão; desconsiderar os efeitos da decisão, ou seu impacto em questões futuras, “consuma uma interpretação desqualificável por imprevidente" 227.

\footnotetext{
${ }^{226}$ Romina Faerman, artigo citado, p. 663, citando o Diario de Sesiones de la Convención Constituyente, t. IV, $34^{\mathrm{a}}$. reunião, pp. 4600-4601. A autora esclarece que o mesmo argumento quanto à intenção do constituinte, com maiores pormenores, pode ser encontrado em trabalho de $\mathrm{N}$. Miniersky, Clausuras y aperturas. Debates sobre aborto, publicado em Buenos Aires, em 2007, ao qual não tivemos acesso.

${ }^{227}$ Ricardo Luis Lorenzetti, Teoria da Decisão Judicial, RT, 2009, p. 321 (citando vários julgados da Suprema Corte e apoiando-se na opinião concordante de Néstor Sagüés).
} 
A proposta de Lorenzetti é dividir o raciocínio judicial em quatro fases. Na primeira, delimitam-se os fatos e identifica-se a norma a eles aplicável, para em seguida, por raciocínio dedutivo (da norma para os fatos), chegar-se a uma proposta de "solução do caso". A interpretação da norma deve incidir nesta fase, para "determinar o seu sentido".

Numa segunda etapa, passa-se ao "controle da solução dedutiva", mediante três análises: a) "olhar para trás", verificando os elementos de consistência, especialmente nos precedentes judiciais, para assegurar tratamento igual aos casos semelhantes anteriormente julgados; b) "olhar para cima", buscando elementos de coerência com as regras gerais do ordenamento; c) "olhar para a frente", analisando as conseqüências jurídicas, econômicas e sociais que poderão resultar, no futuro, da decisão a ser proferida.

A terceira etapa, que diz respeito apenas aos chamados hard cases, propõe a aplicação de um juízo de ponderação de princípios eventualmente em conflito , enquanto a quarta aponta para a necessidade de harmonização de paradigmas, que são elementos pré-condicionantes da decisão (subjetividade do julgador), que devem, de preferência, ser evitados. ${ }^{228}$

$\mathrm{O}$ aspecto relevante o nosso tema encontra-se nas duas primeiras fases (ou "passos") da proposta de Lorenzetti. Ao colocar a interpretação na primeira delas - a da identificação da norma aplicável e seu significado - deixando para um segundo momento análise das conseqüências, o esquema assim proposto tem o mérito de evitar que a interpretação seja contaminada por preferências pessoais do aplicador (o que parece válido tanto para o juiz como para outro intérprete). Nesse modelo, a eventual influência de fatores externos à norma jurídica - como as conseqüências da decisão - ficaria às claras, sem se recorrer a disfarces interpretativos.

${ }^{228}$ Teoria da Decisão Judicial, pp. 159-164. 
Analisando essa possibilidade de síntese especificamente em tema de interpretação constitucional, Bidart Campos tece importantes considerações, reduzindo esquematicamente as várias técnicas a apenas duas: a primeira, que ele chama de histórica ou estática, "retrocede historicamente para descobrir a vontade também histórica do constituinte"; a segunda, que denomina dinâmica, pretende que a constituição seja interpretada segundo as circunstâncias do momento em que vai ser aplicada.

Nesse ponto, Bidart Campos chama atenção para o fato de que "a dinâmica da vida política se desenvolve historicamente”, conjugando presente, passado e futuro. Assim sendo,

"a interpretação dinâmica merece também ser denominada histórica, ou historicista, porque a historicidade da vida não é uma dimensão unicamente retroativa, mas também futurista. A primeira modalidade de interpretação seria histórica, então, no sentido de retroceder à vontade histórica do constituinte; e a segunda também seria histórica - ou historicista - no sentido de computar a historicidade dinâmica como a permanente dimensão constitutiva da vida e da realidade social". 229

A conciliação entre as duas visões é possível se se levar em conta que a vontade do constituinte era que sua obra perdurasse no tempo, como declarado no próprio preâmbulo da Constituição argentina. Assim, a utilização do método dinâmico "não é desprender-se da vontade histórica que teve então o autor, mas, ao contrário, assumir essa vontade com a intenção, nela albergada, de durar e sobreviver”.

Ocorre - e este ponto é de suma importância - que o dinamismo da interpretação não há de ser pretexto para desatender a vontade do constituinte, alterando o claro sentido de suas prescrições. Nas palavras de Bidart Campos, é indispensável que essa tentativa de harmonização entre "duas interpretações aparentemente hostis" tem que deixar um ponto bem ressalvado:

${ }^{229}$ La Corte Suprema: El Tribunal de las Garantias Constitucionales, Ediar, 2010, pp. 46-49. 
“ a interpretação dinâmica e historicista da

Constituição nunca pode chegar ao extremo de sublevar-se diretamente contra a vontade do constituinte claramente expressa na Constituição. Ou seja, não serve para violá-la, nem para dela prescindir, mas sim para lhe dar agilidade, para reajustá-la, para integrar suas lacunas nomológicas, para superar suas imprevisões e, especialmente, para conservar sua continuidade e sua elasticidade de aplicação em todos os eventos e acontecimentos que a realidade mutável colocar diante dela". 230

Conclui Bidart Campos que o juiz - particularmente o juiz constitucional - deve transportar a vontade histórica do constituinte para as circunstâncias atuais, tal como se ele próprio, constituinte, estivesse diante do caso concreto a resolver. Desse modo, "respeitada a fidelidade à vontade ou intenção histórica do constituinte", as duas modalidades de interpretação, histórica e dinâmica, conectam-se e "integram-se em um método unitário". 231

${ }^{230}$ La Corte Suprema, cit. Pp. 49-50 (os destaques são nossos).

${ }^{231}$ La Corte Suprema, cit., p. 50. 


\subsection{Chile}

\subsubsection{As atas da Comissão Ortúzar}

Em 1973, logo após o golpe militar que derrubou o presidente Salvador Allende, a Junta de Governo formou a Comissão de Estudos da Nova Constituição Política da República do Chile (CENC), composta por oito juristas e presidida pelo ex-ministro da Justiça Enrique Ortúzar Escobar. ${ }^{232}$ Conhecida como Comissão Ortúzar, ela se reuniu durante cinco anos, elaborando o texto que, revisto pelo Conselho de Estado, viria a tornar-se a nova Constituição, após sua aprovação em plebiscito realizado em 1980

As atas das reuniões da Comissão Ortúzar, transcrevendo os debates entre seus membros, foram compiladas e distribuídas nas principais bibliotecas do país, e desfrutam até hoje de grande prestígio, sendo consideradas, mesmo após diversas reformas constitucionais e a plena redemocratização do país, como a mais autorizada fonte de interpretação constitucional.

Como assinala Jaime Bassa Mercado, professor da Universidade do Chile, "o recurso às Atas como consulta à história fidedigna do estabelecimento da norma tem sido quase unânime na doutrina e na jurisprudência constitucional". ${ }^{233}$

Fernando Muñoz León, professor de direito constitucional na Universidade Andrés Bello e de ciência política em Yale, também se refere à "persistente prática no meio nacional de recorrer às Atas da Comissão Ortúzar"; reconhece (embora, como veremos, faça graves ressalvas) que há algumas "vantagens" proporcionadas pelo "recorrente emprego desta fonte", que "contêm uma grande

\footnotetext{
${ }^{232}$ Enrique Ortúzar Escobar (1914-2005), foi ministro do Interior, da Justiça e de Relações Exteriores do Chile, entre 1958 e 1964; integrou ainda o Conselho de Estado, que revisou o projeto da nova Constituição, e foi ministro do Tribunal Constitucional por ela criado, em sua primeira composição (1981-1989).

${ }^{233}$ Sobre la dogmática de los derechos fundamentales, artigo publicado no sítio da Universidade de Viña Del Mar (www.uvm.cl), s/d.
} 
quantidade de material interpretativo", produzido por "destacados profissionais", sendo por isso de "uso majoritário" por juízes e professores universitários. ${ }^{234}$

\subsubsection{A interpretação originalista da Constituição}

Para compreender a importância dada aos trabalhos de elaboração constitucional, é preciso ter em mente que a deferência ao elemento histórico e à vontade do legislador tem profundas raízes no pensamento jurídico chileno.

O Código Civil chileno, vigente desde 1857, originário de um projeto elaborado pelo jurista venezuelano Andrés Bello, contém um capítulo específico sobre a interpretação das normas, no qual se encontra o seguinte dispositivo:

“Art. 19. Quando o sentido da lei é claro, não se desatenderá ao seu teor literal, a pretexto de se consultar seu espírito.

Pode-se, no entanto, para interpretar uma expressão obscura da lei, recorrer a sua intenção ou espírito, nela claramente manifestados, ou na história fidedigna de seu estabelecimento" (destacamos).

$\mathrm{Na}$ esteira desse pensamento tradicional, Zapata Larrain, catedrático de Direito Político e Constitucional na Universidade Católica do Chile, propôs oito regras para a interpretação da Constituição, sendo a primeira relativa ao "sentido natural e óbvio das palavras", e a segunda quanto às "palavras técnicas", cujo sentido há de ser procurado nas ciências ou artes de que são provenientes. Vem então a terceira regra, de seguinte teor: "Para definir o sentido de um conceito, o intérprete poderá, ademais, valer-se de uma definição legal qualificada, da opinião jurisprudencial autorizada e dos acordos expressos da Comissão Constituinte”.

${ }^{234}$ La Interpretación Originalista de Nuestra Constitución: Es Posible y Deseable?" (palestra na Universidade do Chile, 2005). 
Assim o explica esse autor:

"Os registros expressos do processo constituinte são um terceiro elemento auxiliar na tarefa de conceituar um termo contido na Constituição. A existência do texto completo das Atas das Sessões da Comissão Constituinte permite consultar os possíveis acordos em torno do sentido de um conceito.

Um caso de acordo expresso produziu-se, por exemplo, na sessão 130, em 30 de junho de 1975, na qual se definiu a palavra lar em relação ao art. 19, número 5.

Em outra registro expresso, a Comissão Ortúzar acordou, na sessão 366, em 4 de maio de 1978, fixar o sentido constitucional do verbo propagar, esclarecendo-se com precisão a sua extensão, relativamente ao antigo artigo $8^{\circ} ., 235$

Seguindo a tendência dominante na doutrina, o Tribunal Constitucional do Chile, instituído pela Constituição de $1980,{ }^{236}$ adota rotineiramente a interpretação de cunho originalista, mediante consulta aos registros das Atas da Comissão Ortúzar, para esclarecer o significado de normas constitucionais. E isto, cabe notar, mesmo tendo-se em conta que a Comissão de modo algum pode ser equiparada a uma Assembléia Constituinte, não só pela origem de sua convocação, mas também porque o anteprojeto por ela elaborado foi sucessivamente revisado pelo Conselho e pela própria Junta de Governo, antes de sua submissão à consulta popular.

Também o Poder Legislativo parece favorecer esse tipo peculiar de originalismo que, à falta de figura equivalente aos "pais fundadores", vai buscar nos debates de um pequeno grupo de juristas, selecionados pelo governo militar para redigir uma nova Carta política, a explicação mais autorizada do sentido e alcance das

\footnotetext{
${ }^{235}$ Patrício Zapata Larraín, La Interpretación de la Constitución, 1990:161-166. Os destaques são nossos.

${ }^{236}$ O primeiro Tribunal Constitucional chileno foi criado Lei n. 17.284, de 23 de janeiro de 1970, atendendo aos reclamos da comunidade acadêmica e tomando como modelo o Conselho Constitucional francês. Composto por cinco membros, tinha a função de controle preventivo de constitucionalidade de leis e outros atos normativos. Pronunciou somente dezessete sentenças, antes de ser extinto pelo governo militar, em 5 de novembro de 1973, sob a alegação de tratar-se de um órgão desnecessário (informações obtidas na página oficial do Tribunal, www.tribunalconstitucional.cl ).
} 
normas constitucionais: o Congresso chileno mantém em seu endereço eletrônico a íntegra das Atas da Comissão Ortúzar, logo após o texto da Constituição, bem como um pormenorizado histórico da redação, revisão e aprovação de cada um dos dispositivos da Carta.

A muitos parece exagerado esse apego à fonte primária das normas constitucionais.

Eduardo Aldunate Lizana, por exemplo, propõe a "relativização" das atas da Comissão como fonte da "vontade constituinte", pois aquele órgão teve um papel de mero assessoramento, fazendo com que seja inadequado "projetar [ nas atas ] uma espécie de autoridade ou vontade duradoura com respeito a seus conteúdos e à forma de entender" o texto da Constituição. ${ }^{237}$

Objeção semelhante, com ainda maior ênfase, é feita por Victor Manuel Avilés, que critica "incisivamente a excessiva tendência originalista existente no Chile, em relação à interpretação da Constituição Política da República em nível jurisprudencial e, principalmente, doutrinário", questionando "onde se deve buscar essa vontade original", já que o poder constituinte não havia sido confiado a uma legítima assembléia e nem mesmo à Comissão de Estudos da Nova Constituição, mas assumido de fato pela Junta de Governo. Porém, apesar da contundência, esse autor acaba por expressar concordância, ainda que parcial, com Zapata Larraín, no sentido de aceitar as atas da Comissão como "um elemento auxiliar a ser considerado" na interpretação da Constituição. ${ }^{238}$

Fernando Muñoz León aponta problemas da mesma natureza. A Comissão era um órgão de assessoria, e seu trabalho ainda foi revisto pelo Conselho de Estado, o que torna inadequado identificá-la com o Poder Constituinte. O texto assim

${ }^{237}$ Eduardo Aldunate Lizana, Derechos fundamentales, 2008:301.

${ }^{238}$ Vitor Manuel Avilés H., Interpretación Constitucional, 2008:10-11; o autor é professor de Direito Constitucional na Universidade do Chile. 
elaborado, ademais, carecia de legitimidade democrática, a tornar inadequado o recurso aos citados documentos como fonte da "melhor versão possível" da Constituição. ${ }^{239}$

Jaime Bassa também faz crítica contundente: após sustentar que as atas "carecem de qualquer legitimidade, tanto do ponto de vista da representatividade política da Comissão Ortúzar, como do ponto de vista da teoria constitucional”, sustenta que "o constante recurso ao trabalho da Comissão somente conseguiu perpetuar uma concepção minoritária e não democrática da Carta, concepção que não é representativa da sociedade", concluindo que "as opções políticas próprias dos que promulgaram a Constituição em 1980 não podem ser impostas em futuras interpretações e aplicações da norma, mais ainda se considerarmos que elas não foram objeto de consenso, em sua origem, pela comunidade". 240

Entretanto, em que pese a indiscutível relevância de tais objeções, é certo que continua amplamente difundida a citação das atas da Comissão como fonte autorizada de interpretação constitucional.

\subsubsection{Interpretação originalista no Tribunal Constitucional}

A título de registro e ilustração quanto ao acima afirmado, selecionamos alguns pronunciamentos do Tribunal Constitucional do Chile - dois dentre as questões julgadas nos anos iniciais de sua atividade, e três de data mais recente, de modo a demonstrar a permanência da linha de interpretação originalista ao longo de várias décadas e distintas composições da corte.

Na STC Rol 16, de 2 de junho de 1983, o Tribunal foi chamado a interpretar o texto original do art. $8^{\circ}$., par $1^{\circ}$. da Constituição, ${ }^{241}$ que proibia a

\footnotetext{
${ }^{239}$ La Interpretación Originalista de nuestra Constitución, cit., item n. 3. Esse autor ressalva, porém, considerar legítimo o texto constitucional vigente a partir das reformas de 1989

${ }^{240}$ El Estado Constitucional de Derecho. Efectos sobre la Constitución vigente y los derechos sociales, 2008:110-111.

${ }^{241}$ Esse artigo foi revogado durante a redemocratização do Chile. A matéria é tratada, de modo bastante distinto, no atual art. 19 da Constituição, que consagra o pluralismo político como direito fundamental.
} 
divulgação de doutrinas que defendessem a violência, a luta de classes ou concepções totalitárias da sociedade, do Estado ou da ordem jurídica. Para tanto examinou, nos itens 10 e 12 da sentença, o histórico da redação desse dispositivo nas atas da Comissão, especialmente no seguinte trecho:

“(...) confirma a interpretação dada ao preceito do referido art. $8^{\circ}$ a história da discussão desta norma na Comissão de Estudos da Nova Constituição. Com efeito, ao início da discussão, o membro da Comissão, Sr. Jaime Guzmán, referiu-se à inspiração que se teve em vista (...) e precisando o alcance daquele artigo (...) configurou-se um preceito que estabelece que ato de pessoas ou grupos, destinado a difundir certas doutrinas, é ilícito e contrário ao ordenamento institucional da República, sublinhando a importância da expressão destinado a difundir doutrinas, porque não se trata de sancionar a quem incorre em atos que constituam delitos tipificados na Lei de Segurança Interior do Estado, nem tampouco a quem sustente divergências nesta matéria. A esse respeito, assinala que o foro íntimo é sagrado e, ademais, há certas manifestações públicas que não devem ser atingidas por essa ilicitude, como por exemplo emitir uma simples opinião - em uma entrevista, numa reunião social, numa conferência, na cátedra (...) (Sessão n. 365, de 3 de maio de 1978)”.

Logo adiante, a mesma sentença transcreve trecho constante da mensagem de encaminhamento do anteprojeto de Constituição, dirigido pela Comissão ao Presidente da República, abordando o mesmo ponto:

"Destacamos que o preceito que propomos tem por finalidade sancionar a propagação de certas doutrinas. Com isso queremos significar, sem dúvida, que ninguém pode pretender invadir o sagrado foro interno da consciência, mas apenas regular as condutas sociais, sendo indiscutível que a propagação de uma idéia é um ato de importantes repercussões para toda a comunidade. Portanto, não se trata de sancionar o pensamento, como mal intencionadamente alguns sugeriram, mas uma ação. Assim mesmo, o termo propagação refere- 
se à difusão realizada com ânimo de proselitismo ou de captar adeptos, e não alcança, por consequiência, a análise científica ou acadêmica, nem a sustentação de uma idéia com fim ou alcance distinto dos englobados pelo verbo propagar."

Na STC Rol 23, de 26 de setembro de 1984, em se questionava a constitucionalidade de um projeto de lei sobre tráfico de entorpecentes, surgiu questão preliminar quanto à competência do Tribunal e a natureza de seus pronunciamentos. Para esclarecer o ponto, o item n. 7 da sentença mencionou "os objetivos primordiais tidos em vista pelo constituinte ao instaurar o Tribunal Constitucional", transcrevendo, em seguida, trecho de informe da Comissão justificando a criação da nova corte, destinada "a velar pelo princípio da supremacia da Carta Fundamental e a resolver os conflitos de caráter jurídico-constitucional que surjam entre os diversos órgãos do Estado e, especialmente, entre o Poder Executivo e Legislativo".

A seguir, invoca-se até mesmo o teor de uma mensagem enviada pelo Presidente Eduardo Frei, em 1969, que resultou na criação do primeiro Tribunal Constitucional chileno, ainda que em moldes bastante distintos, mas já ressaltando sua função de dirimir conflitos entre os poderes (Ata da Sessão da Câmara de Deputados, 18.3.1969, p. 2.200).

Em arguição de inconstitucionalidade registrada no Rol 1298 (sentença de 3 de março de 2010), suscitada em uma ação reividicatória, o Tribunal foi chamado a se pronunciar sobre a significação do art. 19, n. 23 da Constituição, que estabelece o direito à propriedade, qual seja, "a liberdade para adquirir o domínio de todo tipo de bens". Tal dispositivo, assinalou então a Corte, difere de outro que protege aqueles que já possuem algum bem (art. 19, n. 24), e visa disseminar o acesso à propriedade "ao maior número de pessoas". Para fundamentar esse entendimento, foram mencionados trechos de atas da sessão 197 da Comissão, ocorrida em 1.4.1976, no item 36 da sentença:

“TRIGESIMO SEXTO. Que o preceito consagra o direito à propriedade, enquanto que o artigo 19, n. 24 consagra o 
direito de propriedade. Enquanto este último garante o direito de propriedade adquirido, o primeiro estabelece o direito a ser proprietário, o direito a adquirir o domínio de bens para poder incorporá-los a patrimônio privado (E. Ortúzar, na Comissão de Estudos da Nova Constituição; Atas, Sessão 197, $1^{\circ}$. de abril de 1976, págs. 18 e 19).

(....) Como disse o Comissionado Jaime Guzmán, na Comissão de Estudos da Nova Constituição, 'o direito à propriedade é $o$ direito em potência, enquanto que o direito de propriedade é o direito em ato' (Atas, Sessão 197, pág. 19)" (o destaque é do original).

Mais adiante, no item 40 da mesma sentença, o Tribunal fez longa transcrição da intervenção de outro membro da Comissão, na Sessão 149, a respeito da inteligência do citado dispositivo.

Na STC Rol 1710, o Tribunal instaurou, de ofício, processo para examinar a constitucionalidade de dispositivo de lei disciplinadora dos serviços de saúde pública, em que era preciso averiguar se, não obstante suprimida a referência expressa ao "princípio da solidariedade" no texto constitucional, ele poderia ser considerado integrante do conceito de seguridade social. Para dirimir a dúvida, o Tribunal recorreu à fonte habitual:

“CENTÉSIMO VIGÉSIMO NONO. Que cabe ter presente, neste ponto, as Atas Oficiais da Comissão de Estudo do Anteprojeto da Constituição vigente, das quais se extrai a seguinte passagem, que demonstra qual foi o propósito que se teve para introduzir a modificação aludida, especialmente em relação ao princípio da solidariedade: 'O Senhor Ortúzar (Presidente) pergunta ao Senhor Camiruaga (assessor da Superintendência de Seguridade Socialo se poderia definir os princípios de universalidade, uniformidade, integralidade, solidariedade e suficiência, a que se fez referência (...) $O$ sr. Camiruaga aduz que a solidariedade se manifesta como um princípio fundamental; é a essência da seguridade social. Onde não existe o princípio da solidariedade, acrescenta, não se pode falar de seguridade social, senão de algum sistema de seguro obrigatório ou outro similar. (...) É um princípio totalmente oposto ao 
sistema do Direito Civil, que parte da comutatividade: em uma compra e venda os valores devem ser equivalentes. Aqui, não.' (Ata da Sessão $204^{\text {a }}$, pp. 4 e 6); (...)

Afinal, a Comissão optou por não enumerar os princípios da seguridade social, e assim ficou constando do texto constitucional".

O mesmo raciocínio e a mesma citação, por sinal, constaram da Sentença Rol 1218, em seu item n. 30.

Como último exemplo, citamos o importante caso STC Rol 740, de 2007, em que o Tribunal examinou a validade do "Decreto Supremo Regulamentar" n. 48, estabelecendo "Normas Nacionais de Regulação da Fertilidade”. O ponto mais importante desse decreto, que gerou intensos debates na sociedade chilena, era a autorização para venda da chamada "pílula do dia seguinte”, considerada abortiva, e por isso questionada sob o crivo do art. 19 , par. $1^{\circ}$. da Constituição. ${ }^{242}$

Logo de início, a própria presidente Michelle Bachelet, em manifestação dirigida ao Tribunal, transcreveu parte dos debates da Comissão Ortúzar, salientando que somente dois de seus membros haviam externado o entendimento de que o citado dispositivo constitucional proibia o aborto; citou, inclusive, as palavras do próprio Ortúzar, para quem a redação proposta

“... quis fazer uma diferença entre o preceito que consagra o direito á vida e a disposição que entrega ao legislador o dever de proteger a vida do que está para nascer. Aduz que, no primeiro caso, trata-se de consagrar o direito à vida de forma absoluta; no segundo, deseja-se deixar uma certa elasticidade para que o legislador, em determinados casos - como, por exemplo, o aborto terapêutico - não considere o aborto como delito".

\footnotetext{
${ }^{242}$ Eis o teor do dispositivo, na parte que interessa ao presente tópico: "Artigo 19. A Constituição assegura a todas as pessoas: $1^{\circ}$. O direito à vida e à integridade física e psíquica da pessoa. A lei protege a vida do que está por nascer. (...)".
} 
Para contrapor-se a esse sério argumento, o Tribunal valeu-se da mesma receita: transcreveu longos trechos das atas da CENC, com vistas a esclarecer, em primeiro lugar, a amplitude do conceito de "pessoas", contido no caput do art. 19 da Constituição.

Assim, no item 43 a sentença ${ }^{243}$ faz longa transcrição do pronunciamento de membro daquela Comissão (e presidente de uma de suas subcomissões), José Maria Eyzaguirre, em que são feitas considerações sobre esse ponto:

“(...) a todos os membros da Subcomissão [da Propriedade] pareceu muito mais lógico usar a palavra pessoas, em primeiro lugar, porque o conceito de habitantes, utilizado pela Carta de 1925, como disse o sr. Silva Bascunan, circunscreve o âmbito espacial da garantia (...) hoje em dia o Estado não atua apenas dentro de seu território físico, mas também fora dele, em vista de um sem-número de relações internacionais. Ademais, pareceu mais lógico, dentro do pensamento jurídico predominante na Subcomissão, usar a palavra pessoa, que é o verdadeiro sujeito de direito e tem uma conotação filosófica muito mais clara que o termo habitante, porquanto a pessoa é um ser que está dotado de muito maior transcendência que o habitante, que se pode aplicar inclusive àqueles que não são pessoas, sendo este $\mathrm{o}$ sentido que teve presente a Subcomissão (Atas Oficiais da Comissão Constituinte, Sessão n.156 a 7 de outubro de 1975, p. 9)."

A partir desses pressupostos, o Tribunal concluiu que no conceito de "pessoa" assumia relevo não só a condição de sujeito de direitos, mas também a de titular de direitos essenciais, próprios da natureza humana, que vigora desde a concepção, o que corresponde ao espírito da Constituição quando promulgada e foi reafirmado ao discutir-se sua reforma, em 1999, quando ficou constando dos anais do Senado que "o nascituro, desde a concepção, é pessoa no sentido constitucional do termos, e em conseqüência é titular do direito à vida". Esse registro oficial foi aprovado, a pedido do senador Carlos Bombal, com "o objetivo de fazer constar de

\footnotetext{
${ }^{243}$ Redigida conjuntamente pelos ministros José Luis Cea Egaña, Raúl Bertelsen Repetto, Mario Fernández Baeza, Marcelo Venegas Palacios e Marisol Peña Torres.
} 
forma expressa, para a história fidedigna do estabelecimento da norma pertinente", que a reforma proposta (e a final aprovada, adotando-se o termo "pessoas") não deveria ser interpretada no sentido de que a titularidade de direitos somente começa com o nascimento, mas desde a concepção. ${ }^{244}$

Mas o Tribunal contrariou especifica e frontalmente o argumento esposado na manifestação da presidente Bachelet, citando pronunciamentos da Comissão Ortúzar relativamente ao preceito hoje contemplado no art. $19, \S 1^{\circ}$ da Constituição (“A lei protege a vida do que está por nascer”), nos quais assinalou-se que, no entender da Comissão, ele se refere a "um ser existente", "uma pessoa que se quer preservar [para] que esteja viva", para evitar "que se retire algum direito a quem ainda não teve oportunidade de defender-se ou de realizar algum ato"245.

E concluiu assim a maioria do Tribunal:

“...dos antecedentes recordados pode-se concluir que a intenção do Constituinte foi confiar ao legislador as modalidades concretas de proteção da vida do que está por nascer, entendido que se trata de um ser existente e incluído na noção de pessoa, enquanto sujeito de direito, a que alude o caput do art. 19. Esse mandato ao legislador importa a proteção de um direito e não apenas do bem jurídico da vida, distinção que não é menor do que para estes julgadores. Com efeito, se apenas fosse protegida a vida, enquanto bem jurídico, bastaria que o legislador tivesse consagrado mecanismos que assegurem ao nascituro a viabilidade da vida intrauterina até o nascimento. No enanto, o legislador - interpretando corretamente o mandato imposto pela Constituição - estabeleceu ações e instrumentos concretos destinados a que o nascituro tenha a proteção de seus direitos, como qualquer outro titular". ${ }^{246}$

\footnotetext{
${ }^{244}$ Itens 45 e 52 da sentença, reproduzindo diversos pronunciamentos constantes do Diário de Sessões do Senado, 3 de março de 1999, pp. 2562 e seguintes). O destaque é nosso.

${ }^{245}$ Item 57 da STC 740, citando a Sessão n. 87 das Atas Oficiais da Comissão Constituinte.

${ }^{246}$ Item 58 da STC 740.
} 
Importante observar que no item 53 dessa sentença o Tribunal Constitucional trouxe à baila o art. 4.1 da Convenção Americana de Direitos Humanos, que protege o direito à vida "em geral, desde o momento da concepção", o que mais uma demonstra que é possível conjugar inteligentemente o originalismo com outros critérios interpretativos, de modo a convergir para um resultado que atualize o sentido original da norma com novas circunstâncias, em um momento já distante no tempo em que essa mesma norma deva ser aplicada.

Como a decisão nesse caso foi por estreita maioria (cinco votos contra quatro), julgamos oportuno registrar o voto dissidente do Ministro Hernán Vodanovic Schnake, para quem "a transcendência do elemento histórico é descartada na doutrina constitucional contemporânea”, e a interpretação constitucional deve-se orientar

"pela busca da finalidade da norma, situada dentro de um sistema normativo, cuja concreção dependerá das necessidades jurídicas, por sua vez condicionadas e influenciadas pelo contexto sociopolítico e cultural de cada época".

E, na parte final de seu voto, expressando adesão às críticas doutrinárias que mencionamos anteriormente, afirma que

"os pressupostos mínimos de um Estado constitucional e democrática como o atual são incompatíveis com a atribuição do caráter de história fidedigna às atas dos órgãos assessores da Junta Militar, como a chamada Comissão de Estudos da Nova Constituição, tendo-se especialmente em vista que, com várias e substanciais reformas, hoje nos rege um texto constitucional referendado por órgãos que expressam a soberania popular". 
Em síntese, este caso é emblemático porque bem resume a situação do argumento originalista no Chile: majoritário na doutrina e na jurisprudência do Tribunal Constitucional, e acolhido também nos poderes Executivo e Legislativo, é no entanto criticado por uma parcela da doutrina, que encontra respaldo em alguns votos dissidentes da própria corte constitucional.

\subsection{Resumo do capítulo}

Do que foi exposto, cremos ter ficado demonstrado que a abordagem originalista não se restringe de modo algum aos Estados Unidos, como usualmente se faz supor.

Ela é consistentemente adotada na Austrália, em uma versão não radical e coexistente com outros critérios interpretativos, a demonstrar a perfeita compatibilidade entre o respeito à intenção do constituinte e uma aplicação atualizada das normas constitucionais.

Ela está também presente numa das mais relevantes polêmicas do constitucionalismo japonês, com respeito à chamada "cláusula pacifista". Neste caso, mais uma vez desmentindo a freqüente e incorreta relação que se faz entre originalismo e conservadorismo político, a abordagem que visa preservar o sentido original da Constituição é defendida por setores progressistas, que Mark Chinen denomina "idealistas de esquerda".

$\mathrm{Na}$ Europa, ainda que não existam condições objetivamente favoráveis ao desenvolvimento do originalismo - uma vez que os Tribunais e Cortes Constitucionais detém indiscutível legitimidade política para reinterpretar a Constituição - também se observa eventualmente o enfoque originalista: de modo esporádico em Portugal e Espanha, e de maneira mais consistente na Itália, como método auxiliar de interpretação constitucional. 
Voltando a atenção para a realidade sulamericana, vimos que na Argentina o respeito à intenção do legislador sempre foi afirmado pela Corte Suprema como a primeira e mais importante regra de interpretação. No que diz respeito à hermenêutica constitucional, a observância da intenção original do constituinte de 1853 foi fator preponderante nas primeiras décadas de atuação daquele tribunal (a chamada "jurisprudência Bermejo"). Atualmente, o enfoque histórico ou voluntarista perdeu terreno para a interpretação dinâmica, mas prestigiados doutrinadores consideram relevante buscar a conjugação harmônica dessas duas tendências.

Finalmente, observamos que no Chile é predominante especialmente no Tribunal Constitucional - uma forma peculiar de originalismo, em que pesem algumas criticas feitas pela doutrina mais recente. 


\section{CAPÍTULO 4: ENFOQUE ORIGINALISTA EM QUESTÕES CONSTITUCIONAIS BRASILEIRAS (período anterior a 1988).}

\subsection{Explicação prévia}

Seguindo a proposta traçada ao princípio deste trabalho, passamos agora a examinar a presença da argumentação de cunho originalista em questões do constitucionalismo brasileiro.

São evidentes os cuidados e ressalvas necessários ao transplantar para a nossa realidade um critério de interpretação constitucional construído a partir das vicissitudes de outro sistema jurídico, bem diferente do nosso. Evidentemente que não houve no Brasil nenhuma escola ou movimento originalista, de modo similar ao que vem ocorrendo nos Estados Unidos. O que sustentamos é que padrões de análise similares podem ser encontrados, com razoável freqüência, nos comentários de grandes constitucionalistas pátrios e em decisões do Supremo Tribunal Federal, reconhecendo a relevância de elementos históricos, como as intenções reveladas pelo andamento dos trabalhos preparatórios, ou ainda conferindo prevalência ao entendimento com que a norma foi recebida ao tempo de sua edição.

Dividiremos essa análise em duas partes. Na primeira, que constituirá este capítulo, examinaremos brevemente os períodos de vigência de quatro das anteriores Constituições (1824, 1891, 1934 e 1946). Na segunda parte, trataremos de algumas das controvérsias surgidas a partir da promulgação da Constituição de 1988 .

Não serão examinados os períodos correspondentes às Constituições de 1937, 1967 e 1969, nas quais não nos parece fazer muito sentido procurar a "vontade do constituinte" ou o "entendimento original" das normas constitucionais. 
No caso da Carta de 1937, além de ter sido outorgada, ela nunca chegou propriamente a entrar em vigor. ${ }^{247}$

Mais complexa é esse problema no que diz respeito à Constituição de 1967. É altamente questionado o processo de sua elaboração, uma vez que promulgada por um Congresso em final de mandato, convocado extraordinariamente, sob forte pressão do Poder Executivo e sem tempo suficiente para debater com profundidade o projeto de Constituição ${ }^{248}$. De outra parte, seu período formal de vigência - de 15 de março de 1967 a 17 de outubro de 1969 - foi caracterizado por extrema instabilidade política - "um período gravíssimo, de tensão permanente"249 - a inviabilizar sua aplicação e interpretação.

247 "A Carta de 1937, exceção feita aos dispositivos autoritários que serviam aos interesses imediatos do poder, não teve aplicação. A mais simples de suas disposições e a primeira que deveria ter sido posta em prática - o plebiscito que permitiria o referendum popular - não chegou sequer a ser cogitada." (Paulo Bonavides e Paes de Andrade, História Constitucional do Brasil, cit., p. 342). O próprio Francisco Campos, sabidamente o redator da Carta de 1937, admitiu em 1945 que esta nem sequer chegou a vigorar (entrevista de 1945, publicada na Revista Forense 103, pp. 171-177). No mesmo sentido: Celso Bastos, Comentários à Constituição do Brasil (em co-autoria com Ives Gandra da Silva Martins), vol. 1, pp. 308 e 311.

${ }^{248}$ Inocêncio Mártires Coelho relata que em 1967 o Congresso Nacional foi "constrangido a deliberar em sessão extraordinária de apenas 42 dias - de 12-12-1966 a 24-1-1967 - com base em proposta literalmente enviada 'a toque de caixa' pelo Presidente da República, que para tanto dispunha do apoio das Forças Armadas, se necessário até mesmo para o fechamento das Casas Legislativas" (Curso de Direito Constitucional, em co-autoria com Gilmar Mendes e Paulo Gonet Branco, Saraiva, $5^{\text {a }}$. ed., 2010, p. 240; o destaque é do original). Na verdade, o prazo fatal para aprovação final do texto era 21 de janeiro de 1967, sob pena de aprovação tácita, sem emendas, do projeto remetido pelo Executivo, conforme estabelecia o Ato Institucional n. 4, de 7.12.1966. Tal prazo, por sinal, somente foi "cumprido" porque o presidente do Senado, Auro de Moura Andrade, ordenou que todos os relógios do plenário, na data fatídica, fossem atrasados em seis horas... (Ronaldo Costa Couto, História Indiscreta da Ditadura e da Abertura, 1998, pp. 81-82). Por considerarem que os deputados não haviam sido eleitos para tal fim, além de cerceados pelos atos institucionais, Paulo Bonavides e Paes de Andrade chamam o episódio de "farsa constituinte" (História Constitucional do Brasil, cit., pp. 432-433). Wilson Accioli sugere que até se poderia considerar essa Constituição como "outorgada", em razão de "dúvida fundada sobre a legitimidade do que se resolveu denominar poder constituinte delegado, figura desconhecida do Direito" (Instituições de Direito Constitucional, cit., p. 85). Diverge desse entendimento Manoel Gonçalves Ferreira Filho (Comentários à Constituição Brasileira, Saraiva, 2a. ed., 1977, vol. 1, pp. 24-26), para quem a tarefa do Congresso, naquela ocasião, "era a de integração do conteúdo de um ato de Poder Constituinte Originário", ainda que com as características pouco comuns de fixação de prazo e de procedimento. Miguel Reale também considerava irrecusável a legitimidade da Carta de 1967, bem como de todo o processo político que lhe deu origem (Momentos decisivos do constitucionalismo brasileiro, in Revista de Informação Legislativa, vol. 77, p. 67).

${ }^{249}$ Manoel Gonçalves Ferreira Filho, Comentários, cit., p. 31. 
A Constituição de 1969, tal como a do Estado Novo, também não resultou de um processo constituinte, eis que outorgada pela Junta Militar que assumiu o poder, por meio da Emenda Constitucional n. 1. ${ }^{250}$ Além disso, eram inteiramente desconhecidas, à época, as razões que ditaram sua elaboração:

"Em vários casos, é difícil atinar com os motivos das alterações. Realmente, a exegese de várias normas muito seria facilitada se se conhecessem as razões que as inspiraram. Todavia, quase nada se conhece a respeito da elaboração dessa Emenda. Sabe-se que, antes da doença do Pres. Costa e Silva, uma comissão presidida pelo Vice-Pres. Pedro Aleixo, com a assistência do então Chefe da Casa Civil, Rondon Pacheco, a colaboração do Prof. Miguel Reale e de outros, havia preparado uma nova redação da Constituição de 1967. Entretanto, o texto assim elaborado não veio à $\operatorname{luz}(\ldots)$ ". ${ }^{251}$

\subsection{Constituição de 1824}

Alguns esclarecimentos são aqui necessários, especialmente em vista do que afirmamos no item anterior, quanto à inutilidade de buscar a "intenção do legislador" em uma Carta outorgada.

\footnotetext{
${ }^{250}$ Concordamos com a posição adotada por Paulino Jacques, que considera que a Emenda n. 1/69 é, para efeitos práticos, uma nova Constituição (Curso de Direito Constitucional, 10 a ed., Forense, 1987, pp. 126 e 131). Tanto é assim, que o preâmbulo da Emenda n. 1 diz que "a Constituição poderá ser editada" de acordo com o texto que segue, e a Emenda n. 2 já se refere à antecedente como "Constituição Federal". Em obra anterior, o mesmo autor explicara mais pausadamente: "A verdade é que se fizeram cerca de 120 modificações de fundo e 180 de forma na Constituição de 1967 - o que equivale à elaboração de nova Constituição, sob técnica de Emenda, mas que importou numa autêntica revisão, tal a amplitude e profundidade da reforma" (A Constituição Explicada, Forense, $3^{\mathrm{a}}$. ed., 1970). No mesmo sentido: José Afonso da Silva, Curso de Direito Constitucional Positivo, 6 a . ed., p. 78; José Cretella Júnior, Comentários à Constituição Brasileira de 1988, v. 1, p. 45.

${ }^{251}$ Manoel Gonçalves Ferreira Filho, Comentários, cit., p. 36. Somente em 2002 o Senado Federal divulgou as atas de reuniões da referida comissão (A Constituição que não foi - História da Emenda Constitucional n. 1., de 1969.
} 
É preciso deixar bem assentada a indiscutível legitimidade da Constituição Imperial.

Em primeiro lugar, porque seu texto pouco diferia do projeto que havia sido esboçado pela Assembléia Constituinte de 1823, dissolvida por D. Pedro I. ${ }^{252}$ Nesse sentido, escrevendo em 1863, o Barão Homem de Melo já alertava: “muita gente ignora que a atual constituição, que faria o orgulho da mais civilizada nação do globo, é calcada sobre o Projeto feito pela Constituinte". ${ }^{253}$

Aponta esse autor que a Constituição de 1824 era superior na forma e no estilo ao projeto da Assembléia, uma vez que este era pouco mais que um esboço; mas, na verdade, havia apenas quatro diferenças significativas entre eles, pois o projeto dos constituintes não contemplava: a) a existência do Poder Moderador; b) a faculdade do Imperador dissolver a Câmara dos Deputados; c) a renúncia presumida do herdeiro do trono que aceitar uma coroa estrangeira, e d) a possibilidade de o Imperador perdoar somente a pena de morte, na hipótese de condenação de ministro. ${ }^{254}$

Esses aspectos positivos são também ressaltados por Rodrigo Octávio e Domingues Viana, para quem o texto redigido pelo Conselho de Estado, “que se converteu na Constituição Imperial de 1824, fora calcado sobre o projeto da Constituinte, tendo apenas sido modificado o método geral da classificação das matérias, alterando-se a colocação dos artigos e melhorando-se consideravelmente a redação, que no primeiro projeto era defeituosa e prolixa". 255

Também apontando tais circunstâncias, Inocêncio Mártires Coelho ressalta o "clima de composição" com que foi redigida a Carta, que "logrou absorver e superar as tensões entre o absolutismo e o liberalismo”, caracterizando-se

\footnotetext{
${ }^{252}$ Boris Fausto, História do Brasil, Edusp, 1994, p. 149. O projeto da Assembléia chegou a ser divulgado na época, não só pelo Diário da Constituinte, como também pela publicação de 2000 exemplares avulsos. O texto desse projeto encontra-se em A Constituinte perante a História, do Barão Homem de Melo (Senado Federal, 1996; reprodução fac-similar do original de 1863).

${ }^{253}$ Barão Homem de Melo, A Constituinte perante a História, p. 20.

${ }^{254}$ A Constituinte perante a História, p. 21.

255 Elementos de Direito Público Constitucional, F. Briguiet e Cia., Editores, 1913, p. 225.
} 
como "um grande estatuto político (...) fundador da nacionalidade" e "ponto de partida para nossa maioridade constitucional". ${ }^{256}$

Ademais, em que pese o vício de origem, a Constituição ganhou inquestionável legitimidade e geral aprovação após as reformas que se seguiram à abdicação do trono por D. Pedro I, em 1831. Lembram Paulo Bonavides e Paes de Andrade que esse momento assinala não só a verdadeira independência e emancipação da sociedade brasileira, mas também o início da legitimação da Carta Imperial:

"A reforma constitucional da Regência, agitando idéias e conceitos descentralizadores, reacendeu a chama liberal dos constituintes de 1823, apagada pelo golpe do Império. A Carta outorgada recebeu então a chancela do consenso com sua legitimidade purgada mediante a intervenção do órgão de reforma. Tornava-se verdadeiramente uma Constituição."257

A reforma procedida pelo Ato Adicional de 1834, votado por uma Assembléia Geral eleita para esse fim, foi essencial nesse processo de legitimação, como bem ressalta José Reinaldo Lima Lopes:

"Chamo a atenção para o fato de a Carta outorgada de 1824 ter, a juízo dos juristas do Segundo Reinado, mudado consideravelmente de perfil com o Ato Adicional de 1834. Passada a Revolução do 7 de abril de 1831, a reforma constitucional consagrou nas urnas e, pois, na representação popular, o documento constitucional. Assim, para os contemporâneos, ela perdeu seu caráter de carta outorgada, para ser assumida como constituição feita (porque reformada) por representantes populares especialmente convocados". 258

${ }^{256}$ Curso de Direito Constitucional (obra em co-autoria com Gilmar Mendes e Paulo Gonet Branco), Saraiva, $5^{a}$. ed., 2010, pp. 226-227.

${ }^{257}$ História Constitucional do Brasil, Paz e Terra, $3^{\mathrm{a}}$ ed., 1991, p. 110.

258 O Oráculo de Delfos: O Conselho de Estado no Brasil-Império, Saraiva, 2010, p. 9, nota n. 9. 
Assentada essa premissa, esclarecemos que neste tópico, diferentemente dos que lhe seguem, não será destacada a exegese desta ou daquela norma em particular, mas o pano de fundo inerente à atividade interpretativa como então praticada, muito diferente do que hoje conhecemos.

É certo que não ainda não havia um Poder Judiciário independente, não obstante assim o declarasse a Constituição (art. 151). Os juízes não eram inamovíveis (art. 153) e podiam ser suspensos pelo Imperador, "por queixas contra eles feitas" (art. 154); estavam sujeitos a "perder o lugar" por "abusos de poder, e prevaricações" (art. 156) e, em casos de corrupção, por meio de ação popular (art. 157).

A tarefa dos magistrados, bem de acordo com a visão então predominante, resumia-se a aplicar a lei (art. 152). O próprio Supremo Tribunal de Justiça tinha sua competência recursal restrita aos casos de "nulidade manifesta" ou "injustiça” das decisões dos tribunais de relação.

A noção de controle de constitucionalidade era inteiramente estranha à cultura jurídica da época. Como preleciona António Manuel Hespanha, ao falar do constitucionalismo oitocentista em Portugal,

“...embora cumprindo eventualmente uma função estruturalmente semelhante, não se pode - sem grande risco de grandes equívocos - usar a expressão controlo da constitucionalidade (ou justiça constitucional) para referir o sistema antigo de controlo da conformidade das leis (e restantes actos do poder) com o direito. A expressão controlo da constitucionalidade está demasiado carregada de sentidos, na dogmática jurídica do século XX, podendo conduzir a uma reinterpretação falseadora do sistema de garantias do direito e dos direitos em vigor antes das Revoluções. Daí que se prefira, para descrever este último modelo, a expressão controlo da jurisdicidade”.

O mesmo autor salienta que o controle da obediência devida à Constituição "não era especialmente dirigido contra o legislador, nem sequer, em rigor, contra agentes do Estado"; o eventual descumprimento de norma constitucional 
era tratado "num plano individual, e não institucional: o 'infrator' é sempre um indivíduo concreto, funcionário ou não; nunca uma instituição", operando-se tal controle quase que exclusivamente sob a perspectiva da simples punição do infrator, não da anulação do ato.

Por isso mesmo, Hespanha qualifica esse tipo de controle como "uma espécie de efeito horizontal, erga omnes, do primado da Constituição". ${ }^{259}$

A interpretação das leis, assim como a guarda da Constituição, eram atribuições da Assembléia Geral (formada pela Câmara dos Deputados e o Senado), conforme art. 15, incisos VIII e IX da Carta de 1824. Era a chamada interpretação por via de autoridade, ou autêntica, em contraponto à doutrinal (feita pelos juízes e tribunais), como explicado por Pimenta Bueno:

"Interpretar a lei por via de autoridade ou via legislativa, por medida geral, abstrata ou autêntica, termos que são equivalentes, é determinar legítima e competentemente qual o verdadeiro sentido ou disposição que a lei encerra, e que deve ser observado sem mais dúvida ou hesitação, é em suma estabelecer o direito.

Esta interpretação pertence essencial e exclusivamente ao poder Legislativo, não só pela determinação expressa e categórica do artigo constitucional (...) como pela natureza de nosso governo, divisão e limites dos poderes políticos. (...)

Só o poder que faz a lei é o único competente para declarar por via de autoridade ou por disposição geral obrigatória o pensamento, o preceito dela. Só ele e exclusivamente ele é quem tem o direito de interpretar o seu próprio ato, suas próprias vistas, sua vontade e seus fins. Nenhum outro poder tem o direito de interpretar por igual modo, já porque nenhuma lei lhe deu essa faculdade, já porque seria absurda a que lhe desse.

Primeiramente é visível que nenhum outro poder é o depositário real da vontade e inteligência do legislador. Pela necessidade de aplicar a lei deve o executor ou juiz, e por estudo pode

259 Antonio Manuel Hespanha, Hércules Confundido: sentidos improváveis e incertos do constitucionalismo oitocentista: o caso português, Juruá, 2009, p. 125. 
o jurisconsulto formar sua opinião a respeito da inteligência dela mas querer que essa opinião seja infalível e obrigatória, que seja regra geral, seria dizer que possuía a faculdade de adivinhar qual a vontade e o pensamento do legislador, que não podia errar, que era o possuidor dessa mesma inteligência e vontade; e isso seria certamente irrisório.

Note-se que nem se discute, nessa passagem, a necessidade de descobrir a "vontade e inteligência do legislador", tida como sinônimo do "verdadeiro sentido" da lei. Trata-se de uma simples premissa da afirmação seguinte: a interpretação autêntica da lei somente pode vir do legislador, único a conhecer "o pensamento, o preceito dela".

O grande constitucionalista já utilizava um argumento que, transplantado hoje aos problemas relacionados à interpretação constitucional, seria inteiramente subscrito pelos defensores do originalismo:

“.... é também óbvio que o poder a quem fosse dada ou usurpasse uma tal faculdade predominaria desde logo sobre o legislador, inutilizaria ou alteraria como quisesse as atribuições deste ou disposições da lei, e seria o verdadeiro legislador. (....) interpretar a lei por disposição obrigatória, ou por via de autoridade, é não só fazer a lei, mas é ainda mais que isso, porque é predominar sobre ela." 260

Nesse contexto, é fácil concluir o respeito que então se devotava à intenção do legislador - o que também era válido em relação aos autores da Constituição. Disso nos dá um excelente exemplo o Barão Homem de Melo: na sessão da Câmara dos Deputados de 28 de julho de 1826, após a discussão de uma proposta

\footnotetext{
${ }^{260}$ José Antonio Pimenta Bueno, Direito Público Brasileiro e Análise da Constituição do Império, cap. $2, \S 85$.
} 
do governo e antes de proceder à votação, foi solicitado ao ministro da Marinha, Francisco Vilela Barbosa - o visconde de Paranaguá, membro do Conselho de Estado que redigira a Carta de 1824 - que se retirasse do recinto, tendo em vista sua condição de membro do Poder Executivo. O visconde sustentou que tinha direito de ali permanecer, tendo em vista que era também senador, argüindo em seu favor o art. 54 da Constituição. ${ }^{261}$ Embora a interpretação dessa norma não oferecesse maior dificuldade, vale atentar que a Câmara, ao aceitar a opinião do ministro, de modo a permitir sua presença durante a deliberação, deixou registrado que assim o fazia porque "ninguém estava mais habilitado para interpretar a constituição do que aquele que a redigiu". ${ }^{262}$

O reconhecimento desse papel proeminente do Poder Legislativo guardava absoluta coerência com o constitucionalismo liberal dos séculos XVIII e XIX, em que o legislador era considerado como "o povo em assembléia" .263

É preciso ainda observar que o Conselho de Estado, embora teoricamente fosse um órgão apenas consultivo do Poder Moderador, assumiu crescente importância no Segundo Reinado, inclusive em matéria de interpretação constitucional (por exemplo, em conflitos de atribuição entre os outros poderes e no exame das leis provinciais); todavia, nunca chegou a suplantar a autoridade do Poder Legislativo como único intérprete autêntico do sentido das leis. ${ }^{264}$

\footnotetext{
${ }^{261}$ Era o seguinte o teor do dispositivo: "Art. 54. Os Ministros podem assistir, e discutir a Proposta, depois do relatório da Comissão; mas não poderão votar, nem estarão presentes á votação, salvo se forem Senadores, ou Deputados".

${ }^{262}$ A Constituinte perante a História, Senado Federal, 1996 (reprodução fac-similar do original de 1863). O destaque é nosso.

${ }^{263}$ José Reinaldo de Lima Lopes, O Oráculo de Delfos, cit., p. 21.

${ }^{264}$ José Reinaldo de Lima Lopes, ob. cit., p. 348.
} 


\subsection{Constituição de 1891}

\subsubsection{A relevância dos anais da Assembléia}

A primeira Constituição republicana foi, também, a primeira a ser promulgada por uma assembléia constituinte. Os debates e deliberações desta foram cuidadosamente registrados e, nas décadas seguintes, examinados como fonte autorizada de interpretação da nova Carta.

Felisbello Freire, no prefácio à primeira edição de sua História Constitucional da República, de 1894, declarou que um volume inteiro seria dedicado a examinar "com a maior minuciosidade possível a constituinte", propondo-se a "não perder um só elemento que elucide o problema dos fatores da elaboração do direito", tampouco "as mais simples opiniões que foram emitidas no recinto do Congresso", pois se tratava de "elemento histórico indispensável para firmar a verdadeira interpretação da Constituição". ${ }^{265}$, Um ano depois, ao publicar esse prometido volume, explicou o método adotado:

"estudar artigo por artigo do projeto de constituição, oferecido pelo governo ao congresso, as emendas apresentadas, assim como os substitutivos, os discursos com que seus autores procuraram fundamentá-los, a fim de deduzir desse trabalho comparativo o verdadeiro sentido do texto constitucional".

E mais adiante reiterava que esse, a seu ver, era "o mais legítimo meio para chegar à verdade da doutrina constitucional". ${ }^{266}$

Alfredo Varela, escrevendo em 1898, também destacava a importância da consulta às fontes primárias dos trabalhos constituintes, alertando que

\footnotetext{
${ }^{265}$ História Constitucional da República dos Estados Unidos do Brasil, v. I, 1894, p. XII.

${ }^{266}$ História Constitucional da República dos Estados Unidos do Brasil, v. III, 1895, p. XII.
} 
"uma das causas de confusão e erro, ao examinar-se os artigos duvidosos da Carta constitucional, é a falta de um rigoroso estudo determinante do critério interpretativo que deve presidir a tais labores". 267

Reclamando racionalidade e objetividade na interpretação constitucional, considerava inaceitável que "a inteligência das doutrinas que o Congresso prescreveu, ao exercer sua suprema função", ficasse "à mercê do modo de ver próprio de cada um”. E exemplificava que, afastado esse critério objetivo, cada intérprete poderia ler os dispositivos da Constituição com a inclinação que lhe aprouvesse:

"o parlamentarista, de maneira simpática a seu sistema; o presidencial, de maneira a que ganhe vigor o oposto; o monarquista, de maneira a dar-se às instituições a feição do passado; o republicano, a firmar cada vez mais as que preconiza; o autoritário, a fortificar o poder, condição de ordem social, e o demagogo, as franquias do extremo radicalismo, dissolvente e anarquisador". 268

“Ora", dizia então Varela, em advertência de indiscutível atualidade - "a Lei Suprema do país não pode ter dois sentidos. A interpretação do Estatuto fundamental não deve ficar sujeita a estas alternativas e flutuações."

O modo de evitar tal insegurança, para esse autor, seria um só:

"em vez de inquirir qual o pensamento particular de cada pessoa sobre esta ou aquela tese incerta, definir qual o pensamento imperante e vitorioso na Constituinte, a respeito do ponto que tem de ser interpretado". ${ }^{269}$

Após três décadas de vigência da Carta republicana, Agenor de Roure publica outro e mais minucioso registros dos trabalhos da Assembléia, agrupando por temas "as emendas e os debates da Constituinte, facilitando a tarefa dos

${ }^{267}$ Direito Constitucional Brasileiro (Reforma das Instituições Nacionais), Senado Federal, 2002 (reprodução fac-similar da $2^{a}$. ed., Livraria Garnier, 1902), p. 304.

${ }^{268}$ Direito Constitucional Brasileiro, cit., p. 304.

${ }^{269}$ Ob. cit., p. 305. 
estudiosos". ${ }^{270} \mathrm{O}$ autor, na verdade, foi muito além disso, acrescentando freqüentes comentários, sempre revelando a preocupação em demonstrar a "interpretação autêntica" da Constituição, vale dizer, a intenção dos constituintes. ${ }^{271}$

E ainda em 1925, quando publicada postumamente a Theoria $e$ Prática da Constituição Federal Brasileira, de Aurelino Leal, o comentário de cada artigo iniciava-se por longas considerações quanto ao seu histórico na Constituinte, incluindo a transcrição de discursos dos parlamentares, inclusive após a promulgação da Constituição, quando o mesmo Congresso passou a exercer apenas a legislatura ordinária, a que esse autor também emprestava privilegiado valor interpretativo. ${ }^{272}$

A preocupação de registrar os trabalhos preparatórios refletia, pois, o entendimento majoritário quanto à relevância da intenção do legislador para compreensão do conteúdo e finalidade das normas constitucionais. Tais registros eram consultados e citados pelos grandes juristas da época.

\subsubsection{Abordagem originalista em Carlos Maximiliano}

O exemplo mais marcante dessa tendência encontraremos em Carlos Maximiliano. Nos seus Comentários à Constituição Brasileira de 1891 - que Rui Barbosa qualificou como o melhor livro de direito constitucional existente no Brasil $^{273}$ - há freqüentes referências aos trabalhos constituintes, dos quais o autor extrai a exegese que considera correta são extraídas conclusões para a exegese do texto.

\footnotetext{
${ }^{270}$ Agenor de Roure, A Constituinte Republicana, Imprensa Nacional, 1920.

${ }^{271}$ Exemplo disso é o comentário de Agenor de Roure a respeito do art. $6^{\circ}$, em que a falta de maiores debates em plenário teria deixado o importante tema da intervenção federal, a seu ver, "sem o elemento histórico, para uma interpretação autêntica" da Constituição (A Constituição Republicana, v. I, p. 323).

${ }^{272}$ Aurelino Leal, Theoria e Prática da Constituição Federal Brasileira (primeira parte), F. Briguiet e Cia. Editores, Rio de Janeiro, 1925 (a obra ficou incompleta, cobrindo apenas os quarenta primeiros artigos da Carta de 1891).

${ }^{273}$ A referência consta do prefácio do Min. Eros Grau à mais recente edição dos Comentários de Carlos Maximiliano, em 2005, por iniciativa conjunta do Senado Federal e do Supremo Tribunal Federal (v. bibliografia).
} 
Ao chamar a atenção para a gênese dos dispositivos constitucionais, Carlos Maximiliano guardava coerência com o pensamento que deixou explicitado na parte introdutória da obra: "A intenção dos constituintes, demonstrada pelas palavras por eles proferidas dentro, ou fora, do Congresso, é chave para interpretar o estatuto básico". ${ }^{274}$

E, poucas linhas adiante ( $(71-\mathrm{III})$, louvando-se em lição de Willoughby, reitera ser "de rigor o recurso aos Anais e demais documentos contemporâneos, a fim de apurar qual era, na época da Constituinte, a significação verdadeira e geralmente aceita dos termos técnicos encontrados no texto."

É bem verdade que o então Ministro da Justiça - que em breve assumiria uma cadeira no Supremo Tribunal Federal - admitia exceções a essa regra. Por primeiro, concordava com Cooley quanto à dificuldade de conhecer os verdadeiros motivos e razões dos membros da assembléia, muitas vezes de natureza estritamente pessoal e nem sempre declaradas nos debates. De outra parte, a concordância dos constituintes em relação a um determinado ponto podia resultar de razões inteiramente diversas. E concluía que "mesmo que se apurasse, com segurança, o intuito dos constituintes, este não prevaleceria contra a letra expressa da lei".

A leitura dos Comentários, todavia, mostra que tais ressalvas foram enumeradas como prudente exceção ou contraponto à regra geral, isto é, a relevância que esse autor emprestava à intenção dos constituintes - inclusive quanto às proposições por eles rejeitadas. Ao longo da obra, somente uma vez logramos encontrar expressa advertência quanto a "um dos casos em que os votos e discursos proferidos na Constituinte não influem decisivamente nas deliberações dos juízes, nem dos legisladores": tratava-se do art. 63, que impunha restrições à autonomia dos estados e que, a despeito de algumas críticas de constituintes, era interpretado ampliativamente, para garantir, na esfera estadual, a inamovibilidade dos juízes e imunidade parlamentar. ${ }^{275}$

${ }^{274}$ Comentários, § 70-II, p. 101. O mesmo posicionamento, embora com menos ênfase, será mantido pelo autor em sua obra Hermenêutica e Aplicação do Direito ( $\S 371$ e 378).

${ }^{275}$ Comentários, $\$ 408$, p. 645. 
Em contrapartida, como dissemos, é muito freqüente nessa obra a menção aos debates constituintes como fundamento para interpretação dos dispositivos constitucionais. Alguns poucos exemplos serão suficientes para ilustrar esse aspecto da obra.

Comecemos pela regra prevendo a laicidade do ensino “ministrado nos estabelecimentos públicos" (art. 72, § 6). Uma vez que "caiu, na Constituinte, a emenda restritiva" que pretendia acrescentar as palavras fundados ou sustentados pela União, conclui o autor que a regra se aplicava, também, às escolas mantidas pelos estados. ${ }^{276}$

Dentre as atribuições privativas da Câmara e do Senado, previstas no art. 18, parágrafo único da Carta de 1891, não se encontra o poder de punir seus membros por comportamentos "imorais, desordeiros e criminosos". Essa competência constava do projeto de Constituição elaborado pelo Governo Provisório, e não foi acolhida pela Assembléia. No entanto, para Carlos Maximiliano isso não significava a impossibilidade de exercício de tal poder, pois a rejeição do dispositivo ocorrera em virtude de impugnação do deputado Cesar Zama, sob o argumento de que não se tratava de matéria constitucional, mas sim regimental: "Portanto ficou de pé a faculdade de castigar, até mesmo à expulsão, os congressistas julgados pelos seus pares insolentes ou indignos". 277

$\mathrm{O}$ art. $35, \S 4^{\circ}$ da Carta republicana estabelecia incumbir ao Congresso, não privativamente, "prover à instrução secundária no Distrito Federal". Carlos Maxiliano dá notícia de que intérpretes "inovadores" (estes já existiam em 1918...) pretendiam que essa regra não constituía impedimento a que o governo federal investisse no ensino primário. O comentarista nega-o peremptoriamente, porque a qualificação "primária" constava do projeto do Governo Provisório, e foi suprimida após intervenção do constituinte João Barbalho, sob o argumento de que "o ensino primário nem aos Estados competia, e, sim, aos municípios”, daí porque o governo federal não estava autorizado pela Constituição a despender recursos na difusão das

\footnotetext{
${ }^{276}$ Comentários, § 193, p. 221.

${ }^{277}$ Comentários, $\S 254$, p. 288.
} 
primeiras letras. ${ }^{278}$ João Barbalho também faz uma referência nesse sentido, mencionando a modificação operada pela Assembléia. ${ }^{279}$

O projeto enviado pelo Governo Provisório previa que os estrangeiros poderiam votar nas eleições municipais, desde que assim fosse autorizado pelos estados. A supressão dessa possibilidade, em mais de uma votação, levou Carlos Maximiliano a afirmar que não podia ser concedida aos estrangeiros a prerrogativa do voto, nem por lei estadual, nem por lei da edilidade. ${ }^{280}$

Na questão relativa à liberdade de acesso aos cargos públicos e proibição de sua acumulação remunerada - art. 73 - Carlos Maximiliano salienta a rejeição de uma emenda assinada, entre outros, pelos deputados Almeida Barreto e Epitácio Pessoa, que pretendia limitar a proibição de acumulações a "empregos de caráter permanente". Dessa rejeição, bem como do contexto histórico em que a matéria foi discutida, ele extraiu "o espírito" da norma, com muito maior vigor do que deixava transparecer seu simples texto:

"aquela assembléia repeliu a restrição, isto é, deixou extensiva a providência moralizadora e republicana a todos os cargos a que podem aspirar brasileiros, tanto aos civis, como aos militares, aos permanentes e aos temporários, aos administrativos e aos políticos. Foi radical o espírito do texto: visou impedir, em absoluto, o que secularmente se tentara coibir, sem êxito seguro, por meio de lei ordinária". ${ }^{281}$

O prestígio desse tipo de análise haveria, por certo, de influenciar a jurisprudência, e disso Carlos Maximiliano também nos dá um exemplo, ao tratar da competência da Justiça Federal para julgar os crimes políticos (art. 60, alínea “i”). A Lei n. 221, de 21 de novembro de 1894, pretendeu estabelecer uma restrição, excluindo

\footnotetext{
${ }^{278}$ Comentários, $§ 323$, p. 436.

${ }^{279}$ Constituição Federal Brasileira, p. 142.

${ }^{280}$ Comentários, $\S 416$ e 418, pp. 662 e 666-667.

${ }^{281}$ Comentários, $§ 466$, pp. 762-763.
} 
da competência federal o julgamento dos crimes políticos praticados contra autoridades estaduais. Um acórdão do Supremo Tribunal Federal, de 6 de abril de 1907, modificando jurisprudência anterior, declarou "inadmissível", "nula e inaplicável" a restrição, "principalmente porque é ela a reprodução literal precisamente da emenda que o Congresso Constituinte rejeitou por voto expresso". 282

\subsubsection{Abordagem originalista em João Barbalho}

João Barbalho, ele próprio um dos constituintes, também faz em seus comentários muitas alusões aos trabalhos da assembléia, e alguns poucos exemplos bastarão para comprovar a relevância que lhes emprestava.

Assim, no delicado tema da intervenção federal nos estados, o significado de "Governo Federal" (art. $6^{\circ}$ ) deveria ser entendido, no dispositivo que trata da intervenção federal (art. $6^{\circ}$ ), deveria ser entendido como sinônimo de "União Federal", compreendendo cada um dos poderes, e não o Executivo, isoladamente, porque essa era "a lição dos trabalhos preparatórios da Constituição", bem como o entendimento revelado por um Campos Sales, um dos mais atuantes constituintes, e até por membros do Governo Provisório, como Quintino Bocaiúva e Aristides Lobo, cujas manifestações foram transcritas. ${ }^{283}$

\footnotetext{
${ }^{282}$ Comentários, $\S 404$, p. 636.

${ }^{283}$ João Barbalho, Constituição Federal Brasileira, pp. 20-21. Três década mais tarde, já no final da vigência da Carta de 1891, Ernesto Leme ainda mencionará a "profunda divergência" a respeito desse conceito, adotando posição intermediária: "governo federal" abrange os "poderes políticos", não se referindo apenas ao Poder Executivo, mas também ao Legislativo. Admite, porém, que "antecedentes históricos" da Constituinte (aos quais dedica um item específico) levariam à conclusão defendida por Barbalho, "o mais copioso dentre os autores que estudam a questão" (Intervenção Federal nos Estados, 1930, pp. 39-55, especialmente pp. 40 e 44-45).
} 
Na questão relativa à competência do Supremo Tribunal Federal para julgar recursos contra as sentenças dos tribunais estaduais (art. 59, § $1^{\text {o }}$ ), que considera "um dos elementos essenciais da organização federal", Barbalho discorre longamente sobre todas as propostas apresentadas, a partir do projeto do Governo Provisório e passando por todas as discussões em plenário, assim resumidas:

"Do exposto se vê que a emenda tinha por fim ampliar a revisão às decisões sobre direito privado, indo muito além do que pretendia o projeto e fundava-se na alegada necessidade de estabelecer o recurso de revista, como instituto necessário para unificar a justiça e manter a unidade do direito; mas o congresso, contentando-se com a revisão para os casos restritos do projeto, pelas razões que se alegaram de ser a emenda contrária ao sistema federativo, multiplicar inconvenientemente as instâncias e não ter decisiva eficácia para a pretendida uniformidade, rejeitou essa emenda todas as vezes que ela lhe foi apresentada."

Daí extrai João Barbalho a conclusão de que a Constituição não conferia ao Supremo "a faculdade de revisão do direito privado", demonstrando, na passagem com que encerra o tópico, a importância que devotava à decisão constituinte, já alertando contra o risco de interpretações deformadoras do sentido original:

“E em vista disto, poder-se-á dar à Constituição, nesta parte, por via de interpretação, uma inteligência contrária ao pensamento, tão clara e terminantemente manifestado na discussão e votação, do congresso constituinte? Não será interpretar, será reformar.",284

Carlos Maximiliano adota o mesmo raciocínio, lamentando que, àquela altura (em 1918), o Supremo Tribunal, mediante interpretação, estivesse incidindo em manifesta "febre de predomínio" e "hipertrofia de poder":

${ }^{284}$ Constituição Federal Brasileira, p. 242 (os destaques são nossos). 
"Faz-se exatamente o que o constituinte repeliu. Tentaram transformar o Supremo Tribunal Federal em Corte de Cassação, por meio da seguinte emenda de Amphilophio de Carvalho e outros, rejeitada pela Comissão dos Vinte e Um e renovada inutilmente no plenário (....)

Pois bem, o que três vezes foi rejeitado, na assembléia de 1890 , como incompatível com o regime e com os ditames da ciência jurídica, é exatamente o que se pratica na atualidade". 285

Em relação ao "livre exercício de qualquer profissão moral, intelectual e industrial", garantido pelo art. $72, \S 24$, Barbalho indaga se o dispositivo é incompatível com as exigências de título ou diploma para certas profissões, a que responde: "Os Anais do congresso constituinte ministram elementos para firmar-se a solução afirmativa”. Isto porque uma emenda tornando prescindível qualquer titulação acadêmica foi rejeitada, tendo "o presidente do congresso, sem reclamação deste nem observação por parte de quaisquer de seus membros", declarado prejudicadas outras emendas de teor semelhante.

E conclui Barbalho que não cabe ao intérprete alegar que a rejeição poderia ter ocorrido por serem supostamente supérfluas tais emendas: "Do que se disse, do que se fez no congresso, do que está nos Anais absolutamente nada consta que autorize assim crer-se". ${ }^{286}$

Observe-se que Agenor de Roure chegou à mesma conclusão, e pelos mesmos motivos ${ }^{287}$, embora Alfredo Varela invocasse o que entendia ser a

\footnotetext{
${ }^{285}$ Comentários à Constituição Brasileira, § 392, p. 611 e nota n. 3.

${ }^{286}$ Constituição Federal Brasileira, cit., p. 330 (os destaques não são do original). Carlos Maximiliano, a respeito, também noticia a rejeição das emendas que exprimiam "hostilidade aos graus universitários" para embasar a mesma solução, inclusive citando Barbalho (Comentários, § 457, p. 744).

287 “A verdade é que a Constituição não aboliu os diplomas (...) Todas as emendas que visavam abolir os diplomas - e elas foram muitas, repetidas, insistentes, teimosas - caíram no seio da Constituinte. Os seus apresentantes e defensores confessaram que pediam aquela abolição porque ela não estava no projeto emendado pela Comissão" (A Constituinte Republicana, v. I, p. 61; o destaque é do original). Ou ainda: "Com estes argumentos tirados dos Anais (...) não se pode, sem torcer a verdade, sustentar que a constituição aboliu o diploma" (idem, p. 291).
} 
intenção dos constituintes para defender, com extraordinário vigor, opinião diametralmente oposta. ${ }^{288}$

$\mathrm{Na}$ importantíssima cláusula constitucional estabelecendo que o Senado, ao declarar o impeachment do Presidente da República, "não poderá impor outras penas mais que a perda do cargo e a incapacidade de exercer qualquer outro" (art. 33, § $3^{\circ}$.), Barbalho aponta que o histórico da redação da norma, desde o projeto inicial, não deixava dúvida quanto à necessidade de imposição simultânea e inseparável de tais penas. ${ }^{289}$

\subsubsection{Abordagem originalista em Rui Barbosa}

O próprio Rui Barbosa, em mais de uma oportunidade, invocou a intenção do constituinte, revelada pelos Anais da Assembléia, como fundamento para sustentar suas teses quanto à correta interpretação de dispositivos da Constituição de 1891. Citaremos três exemplos desse tipo de abordagem.

O primeiro é relativo à questão da recorribilidade das decisões do Supremo Tribunal Militar para o Supremo Tribunal Federal. A análise textual, e mesmo sistemática, da Carta de 1891 levaria, em princípio, à resposta negativa. Isto porque, ao enumerar as competências recursais do Supremo Tribunal Federal, no art. 59, a Carta de 1891 dizia caber ao STF "julgar, em grau de recurso, as questões resolvidas pelos juízes e tribunais federais" (inciso II), bem como as "sentenças das justiças dos Estados em última instância” (inciso III, § $1^{\circ}$.). Os “juízes e tribunais federais" tinham a competência prevista no art. 60, e neles não se incluía o Supremo Tribunal Militar, cujas atribuições seriam “reguladas por lei” (art. 77, § $2^{\circ}$.).

\footnotetext{
${ }^{288}$ Direito Constitucional Brasileiro, cit., pp. 305-319.

${ }^{289}$ Constituição Federal Brasileira, cit., p. 99. Carlos Maximiliano (Comentários, p. 341, nota 6) manifesta o mesmo entendimento, sem estender-se no assunto, apenas remetendo à opinião (e, lícito presumir, também ao argumento) de Barbalho
} 
A conjugação desses dispositivos, e a própria designação de Supremo, levariam a concluir pela irrecorribilidade das decisões daquele órgão da justiça militar.

No entanto, Rui afirma categoricamente que "as sentenças do Supremo Tribunal Militar são revistas pelo Supremo Tribunal Federal”. E fundamenta essa assertiva no fato de que, durante a elaboração da Constituição, havia sido apresentada proposta que tornava definitivas as decisões da mais alta corte castrense, "idéia que a Constituinte rejeitou". E isto foi, de fato, explicitado pouco tempo depois, com a Lei n. 221, de 20 de novembro de $1894 .^{290}$

Um segundo exemplo é ainda mais incisivo, pois Rui sustenta a prevalência da vontade do constituinte sobre o próprio texto da norma.

Tratava-se da interpretação do art. 34, n. 20, que assegurava ao Congresso "mobilizar e utilizar a Guarda Nacional ou milícia cívica nos casos previstos pela Constituição".

O texto parece referir-se a "milícia cívica" como um sinônimo para Guarda Nacional; nem implicitamente parece autorizar os Estados a constituir suas próprias milícias.

No entanto, Rui afirma que essa disposição "está viciada", por não corresponder ao que a Assembléia Constituinte efetivamente aprovou. Segundo ele, o texto aprovado em redação final dizia caber ao Congresso "mobilizar e utilizar a Guarda Nacional ou milícia cívica DOS ESTADOS, nos casos previstos pela Constituição" (o destaque é do original). E esclarece:

"A frase complementar DOS ESTADOS aceita sempre, através de todas as discussões, até a derradeira, foi, por descuido, ou arbítrio impresumível, subtraída no autografar da lei, entre a sua última aprovação e sua assinatura.

Mercê dessa eliminação, misteriosa e sutil, de que o Congresso, em conjuntura como aquela, não havia de dar fé (...) obliterou-se a enunciação formal, em que o legislador constituinte

\footnotetext{
${ }^{290}$ Rui Barbosa, Comentários à Constituição Federal Brasileira, Saraiva, 1933, vol. IV, pp. 63-64.
} 
deixara positivamente consagrado, acerca da milícia cívica, o direito dos Estados."

E a seguir, anuncia que irá reivindicar aos Estados esse direito, com base no acompanhamento "[d]essa provisão legislativa desde sua nascente nas fontes autênticas da história da constituinte, na publicação oficial de seus debates, fixadas nos Anais". Adverte que "são páginas áridas, mas curiosas e edificantes, ante as quais emudece a controvérsia".

E prossegue mostrando que, desde o projeto do Governo provisório, a disposição equivalente falava nas "forças policiais dos Estados". Por duas vezes o constituinte J. Higino propôs que fosse substituída a expressão "força policial” por "milícia cívica" (Anais, vol. I, p. 102, e vol. II, p. 395). Da primeira vez a emenda foi rejeitada, mas numa segunda tentativa, o próprio autor da proposta fez uma intervenção em plenário, esclarecendo que seu propósito era "a criação de uma milícia cívica, como instituição dos Estados", na qualidade de "reserva do exército, ao passo que a força policial não o é". Embora pertencendo aos Estados, as milícias poderiam ser mobilizadas pelo Governo central, em caso de assim o exigir a defesa "interna ou externa". A proposta recebeu uma emenda aditiva do constituinte Campos Sales, o que motivou o adiamento da votação.

Ocorreu aí, segundo Rui Barbosa, uma série de discussões e "peripécias" que ele relata minuciosamente - sempre citando os Anais da Assembléia - em que os constituintes discutiram várias alternativas para a Guarda Nacional (até mesmo sua abolição). A final, em 11 de fevereiro de 1891, aprovou-se em segunda e última votação que o Congresso poderia "mobilizar e utilizar a Guarda Nacional ou milícia cívica DOS ESTADOS, nos casos taxados na Constituição" (Anais, vol. III, pp. 96 e 139-169).

Após isso, o regimento autorizava mudanças de redação, evidentemente, apenas no que se referisse à forma.

O que ocorreu, nas palavras de Rui, foi "uma inadvertência lastimável", ou "uma usurpação imprudente, que não queremos supor", pois foram suprimidas as palavras "dos Estados", o que implicava alteração não apenas de forma, 
mas de substância. Resultou, desse corte, "a espoliação de um direito dos Estados, no autógrafo apresentado, em 24 de fevereiro, à assinatura daquela Assembléia, que o subscreveu, sem ler, nem lhe ouvir a leitura."

Assinalou, a seguir,

"que a autenticidade dos textos constitucionais não resulta da solenidade da assinatura, firmada no pressuposto da exação do autógrafo; resulta, sim, da realidade das votações, averiguadas pelo seu registro oficial nos anais do Congresso e nos seus arquivos. No caso vertente o Congresso ASSINOU O QUE NÃO TINHA VOTADO”. ${ }^{291}$

E, ao final de nove páginas de pormenorizada descrição das diferentes propostas, debates e votações, concluiu que o importante era fazer valer " $a$ vontade do constituinte”, reconhecendo-se desde logo, independentemente de qualquer retificação formal do texto, "o direito constitucional DOS ESTADOS" de formar suas milícias. $^{292}$

Como último exemplo de interpretação originalista em Rui, mencionaremos a questão envolvendo o art. $70, \S 2^{\circ}$, que declarava "inelegíveis os cidadãos não alistáveis".

A muitos pareceu que, em decorrência daquela regra, todos os cidadãos alistáveis seriam elegíveis. Para "destruir este aleive ao pensamento da lei constitucional", que "trapaceava" o sentido da Constituição, o grande jurista, em texto de 1910, foi à "história mesma desse texto, na própria assembléia que o decretou". Trouxe a data e autoria de proposta apresentada na Constituinte - em 12 de janeiro de 1891, pelos deputados Dionísio Cerqueira e Joaquim da Costa - que pretendia substituir a norma acima mencionada por outra, de seguinte teor: "os cidadãos

\footnotetext{
${ }^{291}$ Não podemos deixar de observar que, mais de um século depois, polêmica similar instaurou-se em relação a artigos "não votados" na Constituição de 1988 (episódio a que faremos referência no capítulo seguinte).

${ }^{292}$ Comentários à Constituição Federal Brasileira, cit., vol. II, pp. 281-289. Todos os destaques, seja em itálico, seja em maiúsculas, são do texto original. As únicas modificações que fizemos foram quanto à atualização da ortografia.
} 
alistáveis são elegíveis”. Desfere então o argumento que, segundo suas próprias palavras, "só por si, encerraria a questão":

"Pois bem. Que fez a Constituinte, a quem se alvitrava substituir por esse o texto atual? Sustentou o texto atual, rejeitando a emenda substitutiva. ${ }^{293}$

Pode haver, já agora, dúvida alguma sobre a excrescência, que se pretende embutir ao art. $70^{\circ}$ ? Quer-se que, com ele, tivesse a Constituinte em mente dizer: 'São elegíveis os cidadãos alistáveis'; nós documentamos, com as suas próprias atas, que, proposto àquela assembléia transformar nesta versão o texto atual, a Constituinte a recusou.

De maneira que o que ora forjam por nos encampar como a vontade legislativa da Constituinte no art. $70^{\circ}, \S 2^{\circ}$, é, ao contrário, estritamente, identicamente, literalmente, uma disposição, que tentada introduzir nesse texto por dois membros da Constituinte, caiu mediante repulsa geral daquela assembléia."294

Em comentário a dispositivo correlato da Constituição - o art. 26, que estabelecia a condição de ser "alistável como eleitor" para um candidato disputar eleições ao Congresso Nacional - Rui Barbosa deteve-se também na explicação de sua origem na Constituinte. O projeto do Governo Provisório estabelecia como condição de elegibilidade "estar na posse dos direitos de eleitor", e por iniciativa de vários deputados, capitaneados por Correia Rabello, a redação foi alterada para "estar na posse dos direitos de cidadão brasileiro e ser alistável como eleitor”. O acréscimo, para Rui, significava claramente que estar "na posse dos direitos de cidadão" não se confundia com a condição de "alistável":

${ }^{293}$ É o próprio Rui Barbosa que fornece o registro dessa deliberação: Anais da Constituinte, vol. II, p. 235, segunda coluna.

${ }^{294}$ Comentários à Constituição Federal Brasileira (coligidos por Homero Pires), Saraiva, vol. III, 1933. Pp. 123-127. 
"Mas por onde nos interessa, neste debate, esse incidente histórico das origens da Constituição republicana, é pela autêntica declaração, em que ele importa, da Assembléia Constituinte, sobre a significação atribuída, na sua linguagem, à frase 'posse dos direitos de eleitor'. Para a Constituinte só estaria na posse dos direitos de eleitor o cidadão brasileiro alistado. $\mathrm{O}$ meramente alistado não tinha posse desses direitos.

Para o demonstrar, aqui transcreveremos as considerações do autor principal da emenda, o Deputado Correia Rabello, esposadas pela Constituinte com uma aprovação imediata e sem reservas.

'Esta emenda', ponderava ele, na sessão de 24 de dezembro (Anais da Constituinte, vol. I, pág. 338, col. 2a ...), 'esta emenda é substitutiva do $\S 1^{\circ}$ do art. 25 do projeto, que estatui: 'estar na posse dos direitos de eleitor'. A diferença é clara, é manifesta. Para justificar a emenda peço desculpa ao Congresso de invocar uma noção elementar em jurisprudência; isto é, a diferença entre o direito a uma coisa e a posse dessa coisa. O direito e a posse não andam sempre unidos, e frequentemente acontece que aquele, que tem o direito a uma coisa qualquer, não tenha conjuntamente o direito à posse. Para que se esteja na posse do direito de eleitor, o art. 70 do projeto em discussão exige, além de certas condições, os requisitos, que são necessários, para que se possa ser eleitor, isto é, o alistamento; de modo que SOMENTE ESTÁ NA POSSE DOS DIREITOS DE SER ELEITOR O CIDADÃO, que, reunidos esses requisitos, SE TENHA TAMBÉM ALISTADO. (....) Logo, é patente que, para se estar na posse do direito de eleitor, se torna essencial, entre outras condições, a do alistamento; e, pois, a prevalecer a doutrina do art. $25, \S 1^{\circ}$, somente é elegível aquele que, tendo o direito de alistar-se, se tenha também alistado'.

Ouvidas essas considerações, que ninguém impugnou, então ou depois, e que terminaram entre manifestações de aplauso da Assembléia (Anais, p. 339; Apêndice, p. 71), a Constituinte, daí a duas sessões, aprovou a emenda Correia Rabello. 
Ficou assim, portanto, declaradamente estabelecido pela Constituinte republicana que, na técnica de sua enunciação,

só se acham NA POSSE dos direitos de eleitor os cidadãos alistados eleitores." 295

Justifica-se a longa citação - em que mantivemos os destaques do texto original - para demonstrar que mais uma vez Rui Barbosa emprestou autoridade decisiva à intenção dos constituintes, que extraiu da aprovação de uma emenda ao primitivo projeto e sua respectiva justificativa, feita em discurso no plenário da Assembléia, salientando a ausência de qualquer impugnação, "então ou depois". Pareceu-lhe relevante, até mesmo, registrar a circunstância de ter sido essa emenda aprovada com palmas...

O ponto era particularmente importante para Rui, porque a "posse" dos direitos de eleitor era menos do que seu "exercício", este exigido para os candidatos à Presidência da República (art. 41, § $3^{\circ}$ ). Por isso ele reitera a explicação, baseada, ainda uma vez, na intenção do constituinte ao fazer a citada distinção:

"Foi por esta maneira de entender o vocábulo posse que se declarou a Constituinte, decidindo só estarem na posse dos direitos de eleitor os que entram no exercício dele pelo alistamento: os alistados. E por isto não se conformou com a redação dada, no projeto constitucional, ao art. $25, \S 1^{\circ}$ (correspondente ao art. $26, \S 1^{\circ}$ da Constituição adotada), que rezava: 'Estar na posse dos direitos de eleitor'.,296

\footnotetext{
${ }^{295}$ Comentários à Constituição Brasileira, vol. II, pp. 103-104. Registre-se que Aurelino Leal, mais de uma década depois, defenderá entendimento semelhante, igualmente apoiando-se nas justificativas apresentadas pelo deputado Correia Rabello (Theoria e Prática da Constituição Federal Brasileira, 1925, p. 341-342).

${ }^{296}$ Comentários, cit., p. 105.
} 
Não importa, para os fins deste trabalho, que a argumentação de Rui Barbosa não tenha prevalecido, diante da conjuntura política da época. ${ }^{297}$ Nosso propósito é sublinhar o emprego da técnica originalista por tão autorizado intérprete da Carta de 1891, em assuntos da mais alta relevância.

Aliás, a própria autoridade de Rui Barbosa em matéria constitucional derivava, em grande parte, do reconhecimento geral de que ele exerceu grande influência na redação da Carta, seja na fase de elaboração do projeto do governo provisório, seja nos debates na Assembléia ${ }^{298}$. Wilson Accioli, possivelmente com algum exagero, chega a afirmar que "há fundamento justificado na assertiva de que teria Rui Barbosa redigido, quase por inteiro, a Constituição de 1891"299. O certo é que Rui era - e ainda é - citado como intérprete privilegiado daquela Constituição por ter sido um dos "Pais Fundadores" da República - fato que por si só remete a uma prática bastante habitual por parte dos defensores do originalismo.

\subsubsection{A questão do sufrágio feminino.}

Desde os tempos do Império houve algumas vozes de prestigio, mas absolutamente isoladas, que defendiam fosse admitida a participação política feminina na vida política. ${ }^{300}$

Proclamada a república, a nova Constituição estabeleceu, em seu art. 71, que eram eleitores "os cidadãos maiores de 21 anos, que se alistarem na forma da lei”; a seguir, previa que seriam inalistáveis os mendigos, analfabetos, praças de pré, religiosos de ordens monásticas ou outras comunidades sujeitas a voto de obediência que importasse renúncia da liberdade individual $\left(\S 1^{\circ}\right)$; os inalistáveis seriam, também, inelegíveis $\left(\S 2^{\circ}\right.$.).

\footnotetext{
${ }^{297}$ Tratava-se da candidatura presidencial do Marechal Hermes da Fonseca, que, como se sabe, não apenas foi aceita como também foi vitoriosa.

${ }^{298}$ Celso Bastos, Comentários à Constituição do Brasil (em co-autoria com Ives Gandra da S. Martins), vol. 1, p. 294.

${ }^{299}$ Instituições de Direito Constitucional, cit., p. 78.

300 José de Alencar, Systema Representativo, pp. 81-82 (obra de 1868).
} 
No entanto, muito embora as mulheres não fossem expressamente excluídas do alistamento, foi praticamente unânime o entendimento de que o termo "cidadãos" referia-se somente aos homens. ${ }^{301}$

A razão para isso havia de ser buscada, segundo os mais autorizados constitucionalistas da época, nos intensos debates travados a respeito, na Assembléia Constituinte de 1891. Disso nos dá autorizado testemunho o eminente João Barbalho, ao comentar o citado dispositivo:

“Além das exclusões expressas na Constituição, subsiste a das mulheres, visto não ter sido aprovada nenhuma das várias emendas que lhes atribuíam o direito de voto político. Os Anais guardam a interessante discussão havida e na qual se exibiram argumentos de toda a ordem, sustentados de parte a parte com mestria e talento e que revelam o incremento que tem tomado entre nós a idéia."

A seguir, o grande constitucionalista cita discurso do deputado Pedro Américo, proferido em 27 de janeiro de 1891, em que esse constituinte, ao justificar seu voto contrário ao sufrágio feminino, afirmava, com uma certa dose de ironia, preferir deixar para outros a "glória de arrastarem para o turbilhão das paixões políticas a parte serena e angélica do gênero humano", acrescentando que a mulher "normal e típica" não costumava ir "às assembléias políticas defender os direitos da coletividade”, preferindo ficar "no lar doméstico, exercendo as virtudes feminis, base da tranqüilidade da família, e por conseqüência da felicidade social."

Embora manifeste sua simpatia pela tese vencida, Barbalho deixa claro que a argumentação acima foi determinante na decisão da maioria. E, para os fins relativos ao nosso tema, não podemos deixar de notar que o método argumentativo desenvolvido pelo notável constitucionalista enquadrar-se-ia perfeitamente na doutrina do original intent, pois foi buscar nos Anais dos debates

\footnotetext{
${ }^{301}$ Situação similar ocorria na interpretação do dispositivo correspondente na Carta de 1824: seu art. 90 previa o sufrágio primeiro grau (observada a restrição censitária) à "massa dos cidadãos ativos em Assembléias Paroquiais", sendo pacífico que esse direito não se estendia às mulheres. Não houve discussão a esse respeito, na frustrada Assembléia Constituinte, o que Costa Porto considera natural, diante "das condições sociais e econômicas do tempo" (O Voto no Brasil, 2002, p. 232).
} 
constituintes - vale dizer, na intenção do legislador - o exato sentido e alcance de um dispositivo constitucional.

A mesma opinião - e com o mesmo fundamento - é exposta por Carlos Maximiliano:

"Várias tentativas houve, na Constituinte, para conferir ao sexo gentil a prerrogativa do sufrágio: fracassaram todas. Oradores acharam a idéia desastrada, fatal e anárquica. Portanto, a assembléia de 1891 recusou conceder às mulheres, casadas, solteiras ou viúvas, o direito de voto". ${ }^{302}$

Agenor de Roure afirma que a idéia do sufrágio feminino teve "defensores e adversários de valor", transcrevendo todas as emendas nesse sentido (desde a primeira, de autoria dos constituintes Lopes Trovão, Leopoldo de Bulhões e Casemiro Júnior, na "Comissão dos Vinte e Um"), bem como os debates travados na Assembléia a esse respeito; a maioria dos discursos, assim como a totalidade das votações, foi em sentido contrário à concessão do voto às mulheres ${ }^{303}$.

Havia, é certo, quem se insurgisse contra a prevalência do elemento histórico, defendendo uma leitura mais literal e objetiva do texto. Era esse o caso de Clovis Bevilaqua, para quem o direito de votar era inerente à cidadania, que a Carta republicana reconhecia às mulheres (art. 69). Argumentava o grande jurista que, não sendo expressamente excluídas as mulheres do conceito de "cidadãos maiores de 21 anos”, no art. 70, não haveria como fazer essa distinção por via interpretativa: “.... se a Constituição quisesse excluir a mulher dos direitos conferidos pelo art. 70,

\footnotetext{
${ }^{302}$ Comentários à Constituição Brasileira, § 424, p. 680. Em nota de rodapé a este trecho, o citado autor faz extensa menção aos Anais da Assembléia (vol. II, pgs. 221, 233-234, 246-247, 329, 467, 519, e vol. III, p. 97), fazendo referência aos discursos pronunciados e a todas as emendas rejeitadas.

${ }^{303}$ A Constituinte Republicana, cit., vol. II, pp. 410 e 418-436. Registre-se que esse autor sugere que a rejeição "poderia" ter acontecido por se considerar implícita a referência às mulheres no termo "cidadãos", mas uma inovação desse porte exigiria dispositivo expresso. Ademais, o pensamento majoritário do Congresso foi confirmado na primeira lei ordinária a tratar do assunto, como a seguir se expõe.
} 
princípio, tê-la-ia incluído nas exclusões constantes do $\S 1^{o}$. Não o fez; logo, está ela compreendida no princípio da cláusula". ${ }^{304}$

Assim também Araújo Castro, que considerava não ser "possível invocar o elemento histórico contra a clareza do texto constitucional". 305

Costa Porto também defende que, "em técnica legal, expressão como cidadãos, utilizada na redação das normas, compreendia os indivíduos de um outro sexo, sendo essa já uma velha lição dos jurisconsultos romanos". Não deixa de ser curioso que, em reforço à sua tese - cujo acerto ninguém colocará em dúvida, hoje em dia - recorreu ao pronunciamento do deputado paulista Almeida Nogueira na constituinte de 1891, lembrando que o uso do gênero masculino pelo legislador seria mera convenção gramatical, abrangendo o gênero feminino. ${ }^{306}$

No entanto, foi exatamente isso que ocorreu. Já na regulamentação do art. 70, operada pela Lei n. 35, de de 26 de janeiro de 1892 , houve exclusão do sufrágio das mulheres, como anotou Vitor Nunes Leal. ${ }^{307}$

Costa Porto menciona a apresentação de dois projetos de lei que tencionavam alterar essa situação. O primeiro, em 1917, do deputado Maurício de Lacerda, não chegou a ser votado. O outro, porém, apresentado pelo senador Justo Chermont em 1919, chegou a ser aprovado em primeira discussão pelo Senado, em 1921 , não logrando aprovação final. ${ }^{308}$

Da mesma forma, os votos de quinze eleitoras do Rio Grande do Norte, na eleição de 1928, foram considerados "inapuráveis" pelo Senado, sob o

\footnotetext{
${ }^{304}$ Carta ao presidente do Estado do Rio Grande do Norte, sem data conhecida - apud Costa Porto, $O$ Voto no Brasil, cit., pp. 234-235.

${ }^{305}$ A Reforma da Constituição, 1924, p. 148.

${ }^{306}$ Costa Porto, $O$ Voto no Brasil, cit., p. 237 e nota 22. A intervenção de Almeida Nogueira é transcrita por Agenor de Roure, A Constituinte Republicana, vol. II, pp. 420-422;

${ }^{307}$ Coronelismo, Enxada e Voto, pp. 253 e 402, n. 24.

${ }^{308}$ O Voto no Brasil, cit., p. 235.
} 
argumento de que a Constituição não outorgara às mulheres o exercício desse direito, por força de uma "venerável tradição doutrinária". ${ }^{309}$

Quase quarenta anos após a Assembléia de 1891, a intenção do constituinte ainda prevalecia sobre a exegese textual. E assim foi durante toda a vigência da Carta republicana.

Somente com a quebra da ordem constitucional, com a Revolução de 1930, é que houve efetiva mudança na matéria, que teve de ser expressa: o Decreto $\mathrm{n}^{\circ}$. 21.076, de 24 de fevereiro de 1932, que instituiu o Código Eleitoral Brasileiro, afirmava em seu art. $2^{\circ}$ que era eleitor "o cidadão maior de 21 anos, sem distinção de sexo”. E a Constituição de 1934, para não deixar nenhuma dúvida, declarava que eram eleitores "os brasileiros de um ou outro sexo, maiores de 18 anos" (art. 108), muito embora o alistamento e o voto somente fossem obrigatórios para as mulheres que exercessem "função pública remunerada" (art. 109).

A Carta de 1937 ainda considerava necessária a expressão “de um ou outro sexo" para se referir aos eleitores (art. 117). A Constituição de 1946, embora declarando serem eleitores "os cidadãos brasileiros maiores de dezoito anos que se alistarem na forma da lei” (art. 131), ainda trazia uma ressalva, àquela altura já dispensável, de que "o alistamento e o voto são obrigatórios para os brasileiros de ambos os sexos" (art. 133).

${ }^{309}$ Parecer publicado no Diário do Congresso Nacional em 27.5.1928, citado por Costa Porto, O Voto no Brasil, cit., p. 237. 


\subsection{Constituição de 1934}

O pouco tempo de vigência da Constituição de 1934 traz como consequiência inevitável a existência de poucas controvérsias a respeito da interpretação de seus dispositivos.

Seguindo a tradição, os trabalhos da Assembléia Constituinte também foram registrados em Anais, que certamente seriam de grande valia para os hermeneutas, caso não fosse tão efêmera a vida desta Constituição.

Convém aqui registrar o magnífico trabalho de Levi Carneiro, um dos elaboradores da Carta, que compilou todos as suas intervenções, pareceres e discursos na Assembléia Constituinte, com o intuito de esclarecer a gênese dos dispositivos constitucionais. ${ }^{310}$

Araújo Castro, um dos poucos comentaristas da nova Carta, incluiu em sua obra sobre a Carta de 1934 diversas referências a esses elementos históricos ${ }^{311}$, nos quais várias vezes se apóia para construir sua interpretação.

Cabe mencionar algumas dessas passagens, a título de exemplo.

A Constituição de 1934 previa duas categorias de deputados: os representantes das associações profissionais, eleitos indiretamente, e os representantes do povo, eleitos pelo sufrágio universal e mediante sistema proporcional (art. 22). No entanto, para as primeiras eleições a serem realizadas para a Câmara de Deputados, em noventa dias, o art. $3^{\circ}$., $\S 4^{\circ}$ mandava aplicar “a legislação em vigor". Como o Código Eleitoral de 1932 estabelecia uma combinação entre o sistema proporcional e o escrutínio em lista, poderia surgir dúvida em relação à plena vigência, desde logo, do

\footnotetext{
${ }^{310}$ Levi Carneiro, Pela Nova Constituição, Rio de Janeiro, 1936.

${ }^{311}$ A Nova Constituição Brasileira, Freitas Bastos, 2a . ed., 1936. Referências a votações e discursos encontram-se, por exemplo, às pgs. 63 (nota 7), 77 (n.17), 78 (n. 18), 95 (n. 18), 109 (n. 12), 116 (n. 8), 139 (n. 4), 144-145, 146 (n. 8), 178 (n. 50), 179-180, 219, 230-231, 249-250, 251 (n. 14), 280, 283 (n.3), 296-298, 347-348, 360, 363, 366-367, 368, 370, 372, 374-381, 404, 406, 423-424, 426 (n. 14), 449-450, 455, 462-463, 465 (n. 5), 466-469, 471-473.
} 
sistema proporcional puro. Para afirmá-lo, Araújo Castro trouxe à baila a exposição de motivos da Comissão Constitucional, em que ficava expresso que o "voto proporcional" deveria ser de "aplicação obrigatória" já para as "primeiras eleições", para então concluir como "evidente que o legislador constituinte não teve outro intuito que o de adotar pura e simplesmente o sistema proporcional", desde logo e sem possibilidade de que este fosse conjugado a qualquer outro. ${ }^{312}$

No importante tópico relativo à dualidade do Poder Judiciário (federal e estadual), considerada como "inerente ao sistema federativo", Araújo Castro relata pormenorizadamente todos os passos da elaboração constitucional, de modo a deixar claros seus exatos contornos (como, por exemplo, a rejeição da unidade da justiça de primeira instância, com a criação de "tribunais de circuito" para julgamento de recursos nas causas de interesse da União). Interessante observar que a regra relativa à declaração de inconstitucionalidade de leis ou atos do poder público, que passou a ser admitida somente se aprovada "por maioria absoluta de votos" dos juízes dos tribunais (art. 179) era prevista, no anteprojeto e no substitutivo da Comissão Constitucional, como aplicável apenas à Suprema Corte. ${ }^{313}$

Cite-se, ainda, em relação ao júri, a comparação entre o anteprojeto e o dispositivo afinal aprovado, desse confronto extraindo-se a conclusão de que, não obstante a ausência de regra expressa na Constituição, o tribunal popular não poderia julgar causas de interesse federal. ${ }^{314}$

A reorganização do Poder Judiciário também ensejou, da parte de Levi Carneiro, a publicação de um artigo em que relatava com minúcias os trabalhos constituintes, explicitando a origem das diversas propostas discutidas e explicando as opções feitas pela Assembléia. ${ }^{315}$

Era possível prever que a completa reformulação do papel do Senado, ao qual passou a caber "a coordenação dos poderes federais entre si",

\footnotetext{
${ }^{312}$ A Nova Constituição Brasileira, cit., pp. 152-153, nota 20.

${ }^{313}$ A Nova Constituição Brasileira, pp. 252-256 e 249-250.

${ }^{314}$ A Nova Constituição Brasileira, p. 263.

${ }^{315}$ Esse artigo foi integralmente transcrito em Pela Nova Constituição, cit., pp. 678-697.
} 
restringindo bastante sua competência legislativa (passava apenas a "colaborar com a Câmara" na elaboração de determinadas leis, taxativamente previstas), geraria grande número de controvérsias, da mais alta importância institucional. Provavelmente em razão disso, ao tratar desse assunto Araújo Castro dedica várias páginas aos debates na Assembléia, para assim demonstrar que o texto final foi resultado de uma "transação" entre as correntes que defendiam, respectivamente, o unicameralismo e o bicameralismo, daí surgindo um "Senado Federal com uma organização que não encontra similar em qualquer outro país", com algumas atribuições que, "longe de concorrerem para a coordenação dos poderes federais, só podem servir para perturbar semelhante coordenação". ${ }^{316}$

\subsection{Constituição de 1946.}

Os trabalhos da quarta assembléia constituinte de nossa história a terceira a concluí-los - também foram cuidadosamente registrados e preservados para estudo e aplicação.

É bastante conhecida a obra de José Duarte, A Constituição Brasileira de 1946 - exegese dos textos à luz dos trabalhos da Assembléia Constituinte, renovando o esforço que fizeram, a seu tempo, Agenor de Roure, Felisbello Freire e Levi Carneiro. Esse autor pretendeu, em suas próprias palavras, reunir "os valiosos elementos prestados à interpretação autêntica do texto constitucional", explicando-o "através dos debates que se travaram, animosos e em estilo alto, na Assembléia Constituinte e em todas as fases da elaboração cuidada e

${ }^{316}$ A Nova Constituição Brasileira, pp. 309-318 (os trechos transcritos encontram-se às pp. 309 e 311). Durante a elaboração da nova Carta, Levi Carneiro já manifestava preocupação com a "criação assombrosa" do Conselho Federal (denominação substituída, ao final, por "Senado Federal"), que instauraria um "bicameralismo camuflado" (Pela Nova Constituição, cit., pp. 655-656). 
prudente do novo Estatuto Político", apresentando a "fonte cristalina", "a exegese autêntica", "o processo de nascimento e de crescimento da norma constitucional". 317

E, como uma das justificativas para esse trabalho, José Duarte cita as palavras do então constituinte Aliomar Baleeiro, assinalando que para os futuros intérpretes da Constituição "serão subsídio precioso a discussão do texto, as opiniões externadas, as emendas oferecidas ou rejeitadas, o conflito de idéias e de doutrinas". E, em corolário a esse pensamento, Baleeiro defendia não só a publicação, mas a ampla divulgação dos Anais daquela Assembléia:

"não é, afinal, uma edição para ser distribuída apenas aos senhores representantes, deputados e senadores, como recordação que cada um de nós levará para a província. Há um interesse mais largo e mais geral. Precisamos que esses Anais sejam distribuídos a todas Bibliotecas Públicas, às Faculdades de Direito, aos Tribunais de Justiça, aos Institutos da Ordem dos Advogados, a todas as instituições culturais do país, e, por que não? Também às estrangeiras.

Aos nobres colegas poderemos dizer que, no meio do aspecto caótico dos nossos Anais encontramos o mais abundante, o mais largo, o mais atual repositório dos estudos sobre os problemas do Brasil. (....) Há, portanto, um interesse vital, em que seja dada a maior divulgação possível aos Anais". ${ }^{318}$

Mesmo em data recente, o Senado Federal publicou outra recompilação, em três alentados volumes, daqueles trabalhos constituintes, pois, nas palavras de Octaciano Nogueira, "a doutrina constitucional originária, em que se baseiam juristas, intérpretes e comentadores, tem de ser necessariamente garimpada nas fontes: os debates e votações das Constituintes". 319

\footnotetext{
${ }^{317}$ A Constituição Brasileira de 1946, 1947, vol. I, pp. 5-6.

${ }^{318}$ José Duarte, cit., vol. I, pp. 22-23, transcrevendo o Diário da Assembléia Constituinte, 12.4.1946.

${ }^{319}$ Doutrina Constitucional Brasileira, 2006 (compilação dos trabalhos da Constituinte de 1946) Introdução, p. 13.
} 
Em sede doutrinária encontraremos ainda alguns exemplos de interpretação levando em conta os intentos do legislador, mas já com menor freqüência do que era observado em relação à Carta de 1891.

$\mathrm{Na} 5^{\mathrm{a}}$. edição de seus Comentários à Constituição Brasileira, atualizados sob a égide da Carta de 1946, Carlos Maximiliano reitera seu pensamento quanto à importância do elemento histórico na interpretação da Constituição, mediante consulta aos registros dos debates ocorridos nas assembléias constituintes e outros documentos contemporâneos, salientando, novamente, que esse recurso às fontes "não encerram insuperável obstáculo a exegese posterior, 320 .

Nessa nova obra, foram mantidas as referências aos Anais da Constituinte de 1890-1891, às quais foram acrescentadas as correspondentes menções aos trabalhos da Assembléia de 1946.

A título de exemplo, veja-se que em relação ao art. $5^{\circ}$, que estabelecia as competências da União, Carlos Maximiliano extraiu diversas conclusões a parir da análise de ocorrências dos trabalhos constituintes:

a) a autonomia dos Estados para resolver disputas territoriais entre si, por acordo ou arbitramento (além da possibilidade expressamente prevista de recurso ao Supremo Tribunal), é afirmada com base na justificativa da Emenda n. 1.387 ao art. $5^{\circ}$, apresentada pelo Deputado Aliomar Baleeiro, e a final aprovada, pela qual foi suprimida a competência da União para intervir em tais questões (item 108, p. $181)$;

b) a rejeição de emendas que pretendiam atribuir à União a competência para legislar sobre tráfego rodoviário resulta em que essa atribuição implicitamente fique com os Estados, assegurando-lhes "autoridade para regular o tráfego interno, de qualquer natureza" (item 121, p. 200);

c) em relação à competência da União para legislar sobre comércio (art. $5^{\circ}$., XV k), a substituição do termo "interno" por "interestadual" teve por objetivo assegurar aos Estados a regulação de seu comércio interno, conforme

${ }^{320}$ Comentários à Constituição Brasileira, 5a . ed., 1954, pgs. 130-133. Itens e páginas a seguir mencionados referem-se a essa edição. 
justificativa do Deputado Aliomar Baleiro, ao apresentar a Emenda 929 (item 121, p. 200);

d) a rejeição de emenda que proibia aos Estados a adoção de hinos, bandeiras e armas próprias levava a concluir pela sua admissibilidade, não obstante o silêncio da Constituição (item 123, p. 204);

e) a rejeição de emenda que pretendia autorizar a União a legislar sobre a permanência de estrangeiros (ao lado de "naturalização, entrada, extradição e expulsão", como acabou constando do art. $\left.5^{\circ} ., \mathrm{XV}, \mathrm{n}\right)$, permitiu inferir que "a permanência do alienígena é livre, não pode constituir objeto de lei especial" (item 123, p. 204).

Em relação à competência dos Estados para legislar de forma supletiva ou complementar à União, Carlos Maximiliano concluiu, a partir das justificativas de três emendas aprovadas ao art. $6^{\circ}$, que a legislação local "visará apenas as necessidades e peculiaridades regionais, providências de ordem pública, que indiscutivelmente se coadunem com o sistema, as exigências e as outorgas de origem federal" (item 124 e nota n. 1, p. 205).

Ao tratar das hipóteses de intervenção federal (art. $7^{\circ}$ ), Carlos Maximiliano queixa-se da falta de registros suficientes dos trabalhos constituintes, razão pela qual ele vai buscar a "exegese fundamentada, remontando às origens peregrinas do art. $7^{o \text { " }}$ - ou seja, os debates na Constituinte de 1891 e da Revisão de 1926 (item 125, p. 206), aos quais irá recorrer, repetidamente, nos itens seguintes (125, $127,131,137,138,141,149,152$ e 158$)$.

Lúcio Bittencourt, em passagem de clássica monografia sobre o controle de constitucionalidade, escrita em 1949, examinará o elemento histórico com vistas a verificar se os constituintes de Filadélfia tiveram em mente atribuir ao Poder Judiciário a prerrogativa de invalidar leis em desacordo com a Constituição. ${ }^{321}$

${ }^{321}$ O Controle Jurisdicional da Constitucionalidade das Leis, $2^{\mathrm{a}}$. ed., Forense, 1968, pp. 19-21. 
Themístocles Brandão Cavalcanti, escrevendo sobre o mesmo tema, já no final do período de vigência da Constituição de 1946, dedica algumas páginas ao critério interpretativo que investiga a intenção dos constituintes, que seria, em tese, "um dos processos mais sadios de interpretação". Aponta que nem sempre essa intenção é clara - especialmente no caso das Constituições brasileiras - o que muitas vezes torna difícil sua descoberta. Reserva, porém, os maiores elogios aos comentários à Constituição norteamericana elaborados por William Crooskey em 1953, "um dos trabalhos mais notáveis no sentido de investigar a intenção do legislador constituinte", reconhecendo que tal "processo tem incontestavelmente o seu mérito". 322

O comentário feito em sede doutrinária será útil para compreender outro pronunciamento do mesmo jurista, desta feita como ministro do Supremo Tribunal Federal, assinalando a necessidade de que esse critério seja sopesado conjuntamente com outros:

“Em interpretação da Constituição não se deve levar em conta somente a intenção do legislador, o sentido e a significação das palavras, o raciocínio lógico no processo de interpretação, mas principalmente o sentido político da interpretação, considerando-se a Constituição como um diploma político". 323

No entanto, é inegável que na vigência desta Constituição o argumento histórico já não terá o mesmo prestígio de épocas anteriores. Para esse declínio certamente terão contribuído a grande instabilidade política entre 1930 e 1945 e a vigência meramente nominal da Carta do Estado Novo, sob o qual o Congresso esteve fechado e o Judiciário viu-se privado de independência, com evidente prejuízo para o exercício da interpretação constitucional.

\footnotetext{
${ }^{322}$ Themístocles Brandão Cavalcanti, Do Controle da Constitucionalidade, Forense, 1966, pp. $38-40$ (a obra foi escrita em 1964). O destaque é nosso.

${ }^{323}$ Representação n. 746-GB, Pleno, j. 7.3.1968. Embora o julgamento seja posterior ao período enfocado, permitimo-nos a citação porque ilustrativa do pensamento já sedimentado no STF (o próprio ministro Themístocles Cavalcanti, que permaneceu apenas dois anos no Tribunal, refletia em sua fala a formação haurida na vigência das Constituições anteriores, notadamente a de 1946).
} 
Um claro indício dessa perda de importância é a jurisprudência do Supremo Tribunal Federal no período, que poucas vezes vai se referir à "intenção do legislador". 324

Um excelente resumo desse panorama consta de um voto de Aliomar Baleeiro, como ministro do Supremo Tribunal Federal, lamentando a "reserva" com que o argumento histórico era encarado pelos intérpretes:

“Temos, então, que o sentido literal é claudicante, de onde presumir-se-á que não estão claros e definidos o sentido e o fim exato do dispositivo. E prova disso jaz em que os defensores da tese favorável à competência da sede da empresa recorrem a variados processos de desarticulação do texto, que reescrevem segundo as intenções atribuídas ao Constituinte. Elas, entretanto, não são claras. Não é demais recordar, neste assunto, a reserva dos hermeneutas aos trabalhos legislativos. Não sou dos que participam dessas restrições, pois, não raro, a ratio juris brota vigorosamente da ‘exposição de motivos', da ‘justificação' do projeto, sobretudo quando provêm do líder representativo de considerável grupo parlamentar. Outro tanto se pode dizer dos pareceres dos relatores nas comissões parlamentares. Muito menos, porém, pode ser creditado à emenda individual, sobretudo de quem não foi dos principais artífices da Constituição".325

\footnotetext{
${ }^{324}$ Em pesquisa no sítio do Supremo Tribunal Federal, relativamente ao período entre 1946 e 1967, encontramos apenas seis acórdãos em que é mencionada a "intenção do legislador": RE 19.13, j., 7.8.1951; RE 11.515, j. 10.1.1953; RE 24.537, j.11.1.1954; MS 4057, j. 8.5.1957 (todos estes de relatoria do ministro Afrânio Costa), e RMS 3793, j. 18.9.57, rel. min. Villas Boas. Em todos esses casos, a referência foi genérica, sem importar pesquisa em trabalhos preparatórios ou no histórico de elaboração das normas.

${ }^{325}$ Voto proferido no RE n. 58.356, j. 28.9.1966. Citado por José Levi Mello do Amaral Júnior, Memória Jurisprudencia: Ministro Aliomar Baleeiro, ed. STF, 2006, p. 32. Os destaques em negrito são nossos.
} 
Desse excerto, conjugado à manifestação anteriormente citada de Aliomar Baleeiro quando deputado, fica claro que para o ilustre jurista baiano sempre tiveram apreciável valor interpretativo os Anais constituintes (e os equivalentes registros da atividade legislativa ordinária), notadamente as exposições de motivos, as justificações das propostas e emendas, em especial se provenientes de líderes partidários ou de constituintes atuantes, assim como os pareceres de relatores de comissões. Seja como legislador, seja como magistrado, seu pensamento a esse respeito permaneceu inalterado ao longo dos anos. ${ }^{326}$

\footnotetext{
${ }^{326}$ Esse ponto tem particular relevo porque o professor Geraldo Ataliba, ferrenho adversário da interpretação segundo a mens legislatoris, costumava citar em desfavor dela uma irônica manifestação do ministro Aliomar Baleeiro, em meio a debate no plenário do STF, no sentido de que não the cabia "psicanalisar os eminentes representantes da Nação" (v., por exemplo: Geraldo Ataliba, Revisão Constitucional, Revista de Informação Legislativa, n. 110, abr./jun/1991, p. 87). A frase foi dita no julgamento do Recurso Extraordinário n. 62.731, em 23.8.1967, também citado por José Levi Mello do Amaral Júnior (ob.cit., pp. 49-50). Estava em causa a admissibilidade de um decreto-lei disciplinando a purgação da mora em locações comerciais, aprovado por decurso de prazo. O Procurador-Geral da República, Prof. Haroldo Valladão, defendendo a constitucionalidade do decreto, argumentou que o silêncio significava a concordância do Congresso. O ministro Baleeiro observou que havia quem sustentasse exatamente o contrário, ou seja, que o silêncio revelava "desaprovação à maneira pela qual esse diploma foi criado"; preferiu, no entanto, evitar essa polêmica, dizendo então a famosa frase. O contexto (tão importante, como sempre, para a exata compreensão do sentido de qualquer enunciado) claramente indica que ele apenas quis dizer que $d o$ absoluto silêncio do legislador não the era dado extrair nenhuma conclusão. Não há, pois, nenhuma contradição no seu pensamento: uma coisa é o domínio da estrita subjetividade, ao qual é impossível adentrar; outra, completamente diferente, é a intenção concretamente manifestada em fatos ou registros objetivos, como justificativas, pareceres, votações e discussões parlamentares.
} 


\section{CAPÍTULO 5: ENFOQUE ORIGINALISTA EM QUESTÕES CONSTITUCIONAIS BRASILEIRAS (a partir de 1988).}

\subsection{Considerações iniciais}

No caso da atual Constituição, a pesquisa da chamada intenção original dos constituintes é tarefa de extrema dificuldade, tendo em vista a magnitude de todo o processo: foram vinte meses de trabalho, sem partir de um texto básico ou anteprojeto; 61.020 emendas foram apresentadas por constituintes, além de 122 emendas populares, discutidas por 34 comissões e subcomissões, em 341 sessões; foram elaborados nada menos do que três projetos completos pelo relator. ${ }^{327}$

E os arquivos do processo constituinte, embora públicos ${ }^{328}$, não foram até hoje adequadamente divulgados, em vivo contraste com a publicação, sempre renovada, dos anais da anteriores Assembléias Constituintes.

Outro ponto que certamente não favorece a abordagem do elemento histórico na interpretação da vigente Constituição, como salienta Manoel Gonçalves Ferreira Filho, consiste no fato de que suas normas "foram quase sempre definidas em acordos realizados a portas fechadas, sem que tivesse maior relevância para isto o que se dizia eloquentemente da tribuna". ${ }^{329}$

\footnotetext{
${ }^{327}$ A esse respeito, veja-se o discurso final de Ulysses Guimarães, Diário da Assembléia Nacional Constituinte, ano II, n. 308, 5.10.1988, pp.14375-82; Adriano Pilatti, A Constituinte de 1987-1988, pp. 1 e 5.

${ }^{328}$ Os textos dos Diários da Assembléia Constituinte, citados ao longo deste capítulo, foram consultados no endereço eletrônico do Senado Federal.

${ }^{329}$ Comentários à Constituição Brasileira de 1988,vol. 1, Saraiva, 1990, p. 11.
} 
Como se não bastassem tais problemas, houve ainda outro que não pode ser ignorado: a votação final feita às pressas, sem maior debate ou reflexão ${ }^{330}$, havendo até notícia de que dispositivos foram incluídos na Constituição sem que tivessem sido submetidos a votação. ${ }^{331}$

Não obstante essas dificuldades, e o pouco prestígio da abordagem originalista na doutrina brasileira atual, propusemo-nos a pesquisá-la a partir de alguns julgamentos do Supremo Tribunal Federal.

Iniciaremos por dois que tratam de questões já superadas: o tabelamento de juros em $12 \%$ ao ano, conforme determinava o art. $192, \S 3^{\circ}$ da Constituição (já revogado), e a tentativa de impugnação do ato convocatório da revisão constitucional prevista no art. $3^{\circ}$ do Ato das Disposições Transitórias.

Examinaremos então, segundo a ordem cronológica dos julgamentos, seis casos já apreciados pelo Supremo Tribunal, enfrentando questões que permanecem atuais: os efeitos do mandado de injunção; o conceito de veículo automotor para fins tributários; o conceito constitucional de racismo; a possibilidade de perda de mandato parlamentar por infidelidade partidária; a tentativa de reinterpretação da Lei de Anistia.

A seguir, trataremos de uma questão ainda pendente de julgamento - a conceituação dos quilombos - finalizando com o resumo das conclusões alcançadas neste capítulo.

\footnotetext{
${ }^{330}$ A esse respeito, Adriano Pilatti, A Constituinte de 1987-1988, p. 315.

331 O primeiro a mencionar essa falha foi o ministro Nelson Jobim, então vice-presidente do Supremo Tribunal Federal, à jornalista Lydia Medeiros (matéria publicada no jornal O Globo, edição de 7.10.2003, sob o título Constituição Cidadãa avanços e revelações; disponível em www.oglobo.com.br.). A revelação ensejou até mesmo um pedido de providências quanto a possível impeachment do ministro Jobim, encaminhado por um grupo de advogados paulistas ao Conselho Federal da OAB. Logo depois, porém, José Afonso da Silva e Jarbas Passarinho também se referiram a outros dispositivos incluídos no texto final pela Comissão de Redação, sem que tivessem sido expressamente votados (Leonardo Furrmann, Aparecem outros artigos da Constituição que não foram votados, Diário de S. Paulo, 9.10.2003, disponível em http://www.sindsaudesp.org.br).
} 


\section{2 - Tabelamento dos juros}

Nos primeiros dias de vigência da atual Constituição, o Partido Democrático Trabalhista ingressou com ação declaratória de inconstitucionalidade em face do Parecer SR-70, proferido em 7 de outubro de 1988 pela Consultoria Geral da República, e aprovado pelo Presidente da República, que negara eficácia imediata ao parágrafo $3^{\circ}$ do art. 192 da Carta da República, por considerar imprescindível sua regulamentação por meio de lei complementar. Segundo o autor da ação, o comando explicitado na primeira parte daquele dispositivo - " $\$ 3^{\circ}$ - As taxas de juros reais, nelas incluídas comissões e quaisquer outras remunerações direta ou indiretamente referidas à concessão de crédito, não poderão ser superiores a doze por cento ao ano; a cobrança acima deste limite será conceituada como crime de usura, punido, em todas as suas modalidades, nos termos que a lei determinar" - não carecia de qualquer complementação ou regulamentação, sendo por isso auto-aplicável.

A medida cautelar foi denegada unanimemente pelo plenário do Supremo Tribunal Federal, em 19 de outubro de 1988.

Foi no julgamento de mérito da ação, ocorrido em 7 de março de 1991, que o Pretório Excelso diretamente enfrentou - pela primeira vez, na vigência da atual Constituição - o tema da interpretação originalista, reconhecendo seu "peso específico, porém relativo", em sede de interpretação constitucional.

Após argumentar que a "arquitetura contextual" daquele dispositivo desvinculava a edição de lei complementar, prevista no caput, e a limitação da taxa de juros, estabelecida em parágrafo autônomo, o autor mencionou a favor de sua tese a tramitação da matéria no processo constituinte, desde o chamado "Projeto B”, aprovado em votação de segundo turno, até o texto final, promulgado em 5 de outubro de 1988. Salientou que na votação em segundo turno, foram derrotadas propostas que explicitamente remetiam à lei a regulamentação da taxa de juros (emendas dos deputados Paulo Macarini e Luís Roberto Ponte). Para o autor, assim decidindo, "o plenário da Assembléia Nacional Constituinte o fez consciente e certo de que votava uma norma para ter vigência e aplicação imediata, com repercussão instantânea na ordem econômica". Transcreveu, nesse sentido, discurso proferido na 
tribuna pelo deputado Divaldo Barbosa e, especialmente, esclarecimento prestado pelo relator Bernardo Cabral, que afirmou:

"A remissão nos termos da lei é feita quanto ao crime de usura. O que se estabelece no texto permanente é que as taxas de juros reais não poderão ser superiores a $12 \%$ ao ano. Isto é auto-aplicável, evidentemente". 332

O Tribunal, todavia, apoiando-se na opinião de respeitados juristas (Hely Lopes Meirelles, Caio Tácito, José Frederico Marques, Manoel Gonçalves Ferreira Filho, Celso Bastos, Ives Gandra da Silva Martins, José Alfredo de Oliveira Baracho, Rosah Russomano, Cid Heráclito de Queiroz e Arnold Wald) considerou que essa possível intenção do constituinte não podia prevalecer sobre a estrutura do art. 192, a revelar que a lei complementar requerida pelo caput, com vistas à reestruturação global do sistema financeiro, aplicava-se também aos seus parágrafos, que não tinham existência autônoma.

Especial relevo para esta tese tem o voto do ministro Celso de Mello, em que teceu específicas considerações sobre o originalismo:

"Não questiono o relevo indiscutível que assume, no plano da hermenêutica constitucional, o elemento histórico, que auxilia - na dicção de Carlos Maximiliano (Hermenêutica e Aplicação do Direito, p. 310, 9ª . ed., 1980, Forense) - 'a exegese do Código básico'. Não ignoro, porém, desse saudoso Ministro e vulto eminente da Corte, a advertência clara por ele feita, ao doutrinar sobre o caráter não-absoluto desse método interpretativo (op. loc.cit.): 'O elemento histórico auxilia a exegese do Código básico, mantida a cautela de só atribuir aos debates no seio da Constituinte o valor relativo que se deve dar, em geral, aos trabalhos parlamentares' (grifei)".

\footnotetext{
${ }^{332}$ Todas as citações referidas neste tópico são extraídas do acórdão proferido no julgamento da ADIn 4-7-DF (disponível em www.stf.jus.br) .
} 
A colocação é exata, cabendo apenas observar que o "valor relativo" que Carlos Maximiliano emprestou aos trabalhos parlamentares, em seus Comentários às Constituições de 1946 e, sobretudo, de 1891, era na verdade bastante significativo, como pudemos demonstrar no capítulo anterior.

Prosseguindo, disse ainda o ministro Celso de Mello:

"Certo, há que se reiterar, trata-se de elemento de grande importância na exegese histórica do próprio processo de elaboração constitucional, como reconhece, 'em razão da especificidade da matéria constitucional', tanto a doutrina nacional (Ana Cândida da Cunha Ferraz, Processos Informais de Mudança da Constituição, p. 40/42, 1986, Max Limonad) quanto a estrangeira (Enrique Alonso Gracía, La interpretación de la Constitución, p. 137/157, 1984, Centro de Estudios Constitucionales, Madrid).

A invocação do valor desse método interpretativo - que considera, como pontos essenciais no processo de revelação da vontade constituinte, subjacente às formulações normativas consubstanciadas na Constituição, os trabalhos parlamentares - introduz o tema, tão versado na literatura jurídica, nacional e comparada, da investigação do original understanding, isto é, a busca do pensamento e a pesquisa da intenção originária dos Constituintes (Enrique Alonso Garcia, op. Cit., p. 142).

O originalismo, contudo - enquanto designação doutrinária desse método de interpretação - possui um peso específico, porém relativo, na exata medida em que seus postulados não condicionam e nem vinculam o intérprete na definição e na fixação do alcance do sentido normativo das regras constitucionais”.

E o ministro concluía esse tópico de seu voto com a advertência de que não se deveria chegar à "exacerbação da vontade do legislador constituinte, $e$ da intenção que o animava em determinado momento histórico", sob pena de reduzir a interpretação constitucional a uma "dimensão voluntarista" (citando Canotilho) ou à "rigidez imobilizante" do sentido da Constituição, se emprestado valor absoluto à 
"intencionalidade subjetiva dos framers, ou seja, da pesquisa da vontade originária dos próprios autores do instrumento constitucional". 333

Nosso ponto de vista, já exposto em capítulo anterior, basicamente coincide com o expressado pelo ministro Celso de Mello. Todavia, é preciso ressalvar que seu douto voto levou em conta a versão inicial e mais ortodoxa do originalismo, certamente a mais divulgada à época do julgamento. Por isso ele não estabelece distinção, que hoje sabemos ser necessária, entre o original intent - ao qual estão endereçadas suas críticas - e o original understanding, que é um conceito distinto.

Em observação bastante sintética, mas de inteira propriedade, assinalou o ministro Moreira Alves em seu voto: “No caso, a pequena valia do elemento histórico é manifesta” (o destaque é nosso). E para fundamentar essa avaliação foi, também Sua Excelência, aos Anais da Constituinte, e ali verificou que não houve grandes debates na votação do $\S 3^{\circ}$ do art. 192: o deputado César Maia manifestou sua dúvida quanto à auto-aplicabilidade do dispositivo, enquanto o deputado Bernardo Cabral foi assertivo ao afirmá-la. Somente isto, de fato, era pouco para identificar o pensamento majoritário da Assembléia.

Registre-se que, mesmo após a decisão do STF, José Afonso da Silva examinou os trabalhos de elaboração da norma para defender a aplicabilidade imediata do tabelamento. E isto não apenas por conta da "normatividade autônoma" do $\S 3^{\circ}$, mas também porque havia sido considerada nas votações da Assembléia Nacional Constituinte como norma independente, somente tendo sido alocado em um parágrafo devido a uma circunstância peculiar do processo constituinte, assim descrita:

"O dispositivo, aliás, tem autonomia de artigo, mas a preocupação, muitas e muitas vezes revelada ao longo da elaboração constitucional, no sentido de que a Carta Magna de 1988 não aparecesse com demasiado número de artigos, levou a Relatoria do texto a reduzir artigos a parágrafos e uns e outros, não raro, a incisos. Isso, no caso em exame, não prejudica a eficácia do texto". ${ }^{334}$

\footnotetext{
${ }^{333}$ Os destaques em negrito são do texto original.

${ }^{334}$ Curso de Direito Constitucional Positivo, 6 ${ }^{\text {a }}$. ed., 1990, p. 695; 20ª . ed., 2002, p. 803. Como veremos mais adiante, ao tratar dos efeitos do mandado de injunção, não foi esta a única vez que o ilustre constitucionalista valeu-se do exame das intenções do legislador constituinte.
} 


\subsection{A revisão constitucional e o plebiscito (arts. $2^{\circ}$. e $3^{\circ}$. do ADCT)}

\subsubsection{O surgimento da controvérsia}

$\mathrm{O}$ art. $3^{\circ}$. do Ato das Disposições Constitucionais Transitórias estabeleceu que "a revisão constitucional será realizada após cinco anos, contados da promulgação da Constituição, pelo voto da maioria absoluta dos membros do Congresso Nacional, em sessão unicameral".

Um grupo de juristas defendia, no início da década de 1990, que o art. $3^{\circ}$ deveria ser entendido em conjugação com o antecedente, que convocava plebiscito para decidir sobre a manutenção da república ou eventual retorno à monarquia, bem como a opção entre os sistemas de governo presidencialista e parlamentarista. Como a consulta popular deliberara por manter tanto a república como o presidencialismo, defendia-se que a revisão não mais deveria ocorrer, por suposta perda de seu objeto.

Esse era o entendimento de Paulo Bonavides ${ }^{335}$, Geraldo Ataliba $^{336}$ e Valmir Pontes Filho ${ }^{337}$.

A grande maioria dos autores, todavia, não fazia essa vinculação, podendo ser desde logo citada a lição de José Afonso da Silva, para quem o art. $3^{\circ}$. abria "um processo mais facilitado de reforma constitucional geral, se as circunstâncias político-sociais aconselharem uma mudança mais ampla no texto da vigente Carta Magna”. 338

Esse autor, por sinal, admitia que a revisão prevista no art. $3^{\circ}$ não se submeteria nem mesmo às cláusulas pétreas ${ }^{339}$, no que foi acompanhado por Nagib Slaibi Filho ${ }^{340}$.

\footnotetext{
${ }^{335}$ A Constituição Aberta, 1993, p. 91.

${ }^{336}$ Revisão Constitucional, Revista de Informação Legislativa 110, abr./jun. 1991, pp. 87-90.

${ }^{337}$ Curso Fundamental de Direito Constitucional, Dialética, 2001, pp. 95-96.

${ }^{338}$ Curso de Direito Constitucional Positivo, RT, 6ª . ed., 1990, p. 58 (os destaques são nossos).

${ }^{339}$ Curso de Direito Constitucional Positivo, cit., p. 59/60.
} 
Nagib Slaibi Filho sugere que a posição vinculando a revisão ao resultado do plebiscito devia-se à crença, por muitos partilhada, "que a revisão constitucional poderia retroceder certos avanços sociais da Constituição de 1988", tendo em vista a "maioria liberal" que então se formara no Congresso Nacional. Nesse sentido, cita trabalho de Cármen Lúcia Antunes Rocha, escrito em 1992, expressando grande preocupação com uma "onda revisionista" que divisava no parlamento, capaz de "excluir do texto constitucional as conquistas que nele figuram". 341

Essa mesma autora, em data posterior, ainda perguntava "por que se aceitaria uma revisão facilitada, fragilizada e fragilizadora da Constituição, transgressora da garantia de sua própria existência, pela ação desembaraçada e descomprometida de deputados e senadores, reunidos em sessão unicameral (...) ?"342

O próprio professor Paulo Bonavides, quando já superada a questão, deixou clara sua posição pessoal contrária à revisão constitucional, por temer que ela acarretasse "irreparáveis danos" à ordem constitucional, servindo a um "projeto revisionista" das "poderosas elites conservadoras". Relata que, para impedir a revisão nos moldes decididos pelo constituinte (reunião unicameral do Congresso, e aprovação das deliberações por maioria absoluta), chegou a apoiar a convocação de uma assembléia revisora, por emenda constitucional. ${ }^{343}$

Nesse contexto, a tese que buscava limitar o âmbito da revisão constitucional à decisão popular no plebiscito assume claros contornos de expediente tático, utilizado para alcançar um objetivo político. Se este procedimento é inegavelmente legítimo, no plano das convicções pessoais, não é menos certo que extrapola os limites de uma interpretação puramente jurídica - ponto que será importante para a conclusão deste tópico.

\footnotetext{
${ }^{340}$ Direito Constitucional, Forense, 2000, p. 53. Esse autor cita, no mesmo sentido, a opinião de Derly Barreto e Silva Filho, em artigo intitulado O poder constituinte de revisão e as cláusulas pétreas.

${ }^{341}$ Direito Constitucional, cit., p.. 52, nota 22.

${ }^{342}$ República e Federação no Brasil, Del Rey, 1997, p. 83.

${ }^{343}$ Teoria do Estado, Malheiros, $3^{\text {a }}$. ed., 1995, pp. 372-376.
} 


\subsubsection{A Decisão do Supremo Tribunal Federal}

Com base na mencionada tese, o então governador Roberto Requião ingressou com ação direta de inconstitucionalidade, impugnando a Resolução n. 1/93 do Congresso Nacional, que dispunha sobre o funcionamento dos trabalhos de revisão constitucional.

No julgamento em Plenário dessa ação - ADI 981-8-PR - em que se discutiu tão-somente o pedido de medida cautelar, o ministro Marco Aurélio foi o único a expressamente endossar o fundamento de que, com o resultado do plebiscito, não mais seria possível a revisão. Em típica postura ativista - mas com elogiável transparência ao expor suas verdadeiras razões - deixou clara sua posição pessoal contrária à revisão, por considerar que ela transformava a Constituição em "um diploma provisório". Afirmou haver "impropriedade" na redação do preceito do art. $3^{\circ}$. em artigo autônomo: para o ministro, seu conteúdo deveria constar de um parágrafo do art. $2^{\circ}$. , porque a seu ver não seriam normas distintas. E concluiu: "Para mim, (....) a razão de ser da revisão constitucional não veio à balha, já que, mediante o plebiscito, houve a manutenção do statu quo"344.

Postura diametralmente oposta foi adotada por outros dois ministros. Sepúlveda Pertence manifestou, "como cidadão", "seus "temores" quanto “à prenunciada Revisão Constitucional”, e Carlos Velloso disse considerá-la "inoportuna e impatriótica". Todavia, ambos votaram contra o deferimento da cautelar: o primeiro, por reconhecer que a tese limitadora da revisão aos resultados do plebiscito estava "quase fatalmente destinada à derrota", e o segundo por admitir que não poderia se afastar do texto da Constituição.

\footnotetext{
${ }^{344}$ Ao ler o voto do eminente ministro, não podemos deixar de recordar a advertência de Roberto Bork, em artigo escrito em 1982: o juiz que se dispõe a olhar para além do texto da Constituição sempre olha, apenas, para dentro de si mesmo (v. Goldford, The American Constitution and the Debate over Originalism, Cambridge, 2005, p. 174).
} 
Mas o Tribunal afastou por ampla maioria a postulação, constando na ementa do julgado que "o resultado do plebiscito de 21 de abril de 1993 não tornou sem objeto a revisão constitucional, a ser feita "uma só vez",.345

Ressalte-se que o enfoque originalista esteve presente em um dos pontos da fundamentação do voto do relator. Para afirmar que a revisão seria única, o ministro Néri da Silveira foi buscar apoio nos debates havidos durante a votação do dispositivo, deles extraindo argumento de reforço quanto à intenção dos constituintes, que não constava expressamente do texto (embora também pudesse ser deduzida, é claro, do fato de tratar-se de disposição transitória). Transcrevemos, para maior clareza, esse trecho de seu voto:

"Quanto à Constituição de 1988, nela, também, se previram a 'emenda', na Parte Permanente - art. 60, e a 'revisão'; esta, porém, nas Disposições Transitórias, art. $3^{\circ}$., a indicar sua realização, 'uma só vez', como restou amplamente esclarecido na votação do Destaque n. 59, relativo à Emenda n. 1763, de autoria do nobre constituinte Darcy Deitos, que propunha se inclú́sse, no texto do art. $3^{\circ}$., a locução aludida, o que veio a ser considerado desnecessário (Diário da Assembléia Nacional Constituinte, de 1.9.1988, pág. 13.989).”

\subsubsection{Análise originalista da questão}

A visão originalista, prestigiada pelo relator da ação para resolver uma questão acessória, havia sido ridicularizada por Geraldo Ataliba, em artigo em que defendia a total vinculação entre a revisão constitucional e o resultado do plebiscito. Em tom bastante inusitado, dizia que a posição contrária resultava do

\footnotetext{
${ }^{345}$ Votaram pelo indeferimento da liminar, além do relator, ministro Néri da Silva, os ministros Sepúlveda Pertence, Paulo Brossard, Octávio Gallotti, Sydney Sanches, Celso de Mello e Carlos Velloso; sessão de 17 de dezembro de 1993 - acórdão consultado no endereço eletrônico www.stf.jus.br.
} 
“desconhecimento da ciência do direito constitucional”, perante a qual "a eventual intenção do legislador nada vale (ou não vale nada) para a interpretação jurídica”, porque "a lei é mais sábia que o legislador”. Invocou o que acreditava ser "a lição de Baleeiro" para sugerir que se deixasse "aos psicanalistas desocupados investigar a vontade do legislador". 346

A ironia agressiva dessa crítica demonstra, mais uma vez, que a paixão política raramente acompanha a razão jurídica. E cabe aqui reiterar: ainda que se admita que a lei possa ser mais sábia que o legislador, a Constituição, como ensina Ives Gandra da Silva Martins, não costuma ser mais sábia que o constituinte.

Em verdade, o argumento originalista era aqui o caminho mais adequado para dar solução à controvérsia. Isto foi bem apontado por Manoel Gonçalves Ferreira Filho: "Os anais da Constituinte mostram a completa desvinculação entre a proposta de plebiscito e a de revisão constitucional. Há, portanto, entre os arts. $2^{\circ}$ e $3^{\circ}$ das Disposições Transitórias apenas uma contigüidade, nada mais. 347

Ives Gandra da Silva Martins também foi buscar na origem dos citados dispositivos o argumento para refutar, serena e objetivamente, a tese da vinculação entre os arts. $2^{\circ}$. e $3^{\circ}$. do ADCT:

"Alguns constitucionalistas têm defendido a tese de que esta reforma apenas se poderia realizar após o resultado do plebiscito e à luz da decisão popular que optará entre a monarquia e a república, assim como entre o presidencialismo e o parlamentarismo, limitandose a adequar o texto constitucional à forma e ao regime de governo que resultarem aprovados nesse plebiscito.

$\mathrm{O}$ argumento isolado de tal corrente reside em vir o art. $3^{\circ}$. do ADCT depois do art. $2^{\circ}$., este fazendo menção ao plebiscito e aquele à revisão constitucional.

Em que pese o respeito pelos que defendem tal postura, inequivocamente minoritária, não me parece deva a

\footnotetext{
${ }^{346}$ Trata-se, e o dizemos com o devido respeito ao saudoso professor, de uma interpretação incorreta e descontextualizada, que não traduz o pensamento do ministro Aliomar Baleeiro. Veja-se a nota final do capítulo anterior, no item relativo à Constituição de 1946.
}

${ }^{347}$ Do Processo Legislativo, $3^{\text {a }}$. ed., 1995, p. 281 (tb. na 6 $6^{\text {a }}$ ed., 2007, p. 291). 
revisão constitucional limitar-se a estes dois pontos objeto de plebiscito.

De início, por serem ambos os artigos de origem diversa. $\mathrm{O}$ art. $2^{\circ}$. saiu do trabalho isolado e persistente do deputado Cunha Bueno, que encontrou, na fórmula original, maneira inteligente de contornar a cláusula pétrea constante do art. $47, \S 1^{\circ}$. da E.C. n. 1/69 (...)

Em defesa da proposta do deputado Cunha Bueno, que apesar de isolada, recebeu fantástico apoio dos congressistas com poderes constituintes (quase 500 assinaturas da "esquerda" e da “direita”), está o fato de que a decisão será do povo e a soberania popular será exercida da forma mais pura possível (...)

A verdade, todavia, é que o art. $2^{\circ}$. do ADCT não tem qualquer ligação com o artigo $3^{\circ}$., cuja inspiração imediata é o direito português (...)."

Rememorando o histórico dos trabalhos da Assembléia Constituinte, veremos que nenhuma das propostas - seja quanto ao plebiscito, seja quanto à revisão constitucional - constava do Primeiro Substitutivo apresentado pelo relator Bernardo Cabral, em agosto de 1987, à Comissão de Sistematização ${ }^{349}$.

O plebiscito foi uma solução de compromisso entre os grupos que digladiavam na ANC em favor do presidencialismo ou do parlamentarismo (essa questão, e a duração do mandato presidencial, foram as que mais profundamente dividiram a Assembléia, e quase levaram a um impasse ${ }^{350}$ ).

${ }^{348}$ A Constituição de 1988 e diretrizes para a reforma constitucional - disponível no endereço eletrônico http://www.gandramartins.adv.br/artigos.asp. Gostaríamos de registrar que ouvimos o mesmo argumento do então Senador (e destacado constituinte) Mário Covas, em reunião realizada em 1994 com um grupo de membros do Ministério Público de São Paulo: os artigos $2^{\circ}$. e $3^{\circ}$. do ADCT tiveram origens distintas e foram votados separadamente, tendo sido inteiramente fortuita a sua colocação contígua, no texto final, pela Comissão de Redação.

${ }^{349} \mathrm{Cf}$ http://www.camara.gov.br/internet/constituicao20anos/DocumentosAvulsos/vol-235.pdf.

${ }^{350}$ A esse respeito: Adriano Pilatti, A Constituinte de 1987-1988, 2008, pp. 250-252. Anota esse autor, com remissão aos Anais da ANC, que a votação do mandato presidencial, em 22 de março de 1988 , foi a primeira vez em que registrado o voto de todos os constituintes. 
Quando já acordada a realização da consulta popular, aprovou-se uma emenda que nela incluía a indagação quanto a eventual retorno à monarquia, com a finalidade de resgatar, segundo seu autor - o já mencionado deputado Cunha Bueno - uma promessa centenária, feita logo após a proclamação da República.

Inteiramente diversa foi a origem do art. $3^{\circ}$. do ADCT. Inspirado no art. 286 da Constituição Portuguesa de $1976,{ }^{351}$ o art. $3^{\circ}$ do ADCT era resultado da convicção generalizada - não só entre os constituintes - de que o texto em vias de ser aprovado contemplava diversas inconsistências, que reclamavam uma reflexão mais pausada $^{352}$; estimou-se que o intervalo de cinco anos (tal como no precedente português), bem como a renovação do Congresso nas eleições marcadas para aquele ano, seriam circunstâncias favoráveis a essa ponderação. O comentário de Manoel Gonçalves Ferreira Filho é incisivo: A razão determinante da revisão prevista foi a tomada de consciência de que o texto da Constituição era insatisfatório, inadequado, prolixo, de modo que rapidamente seria necessário refazê-lo (ou revisá-lo) por inteiro". 353

E o próprio conceito de revisão diz respeito a "uma reapreciação ou reexame de matéria constitucional integralmente, para modificação de forma ampla ou parcial em suas linhas mestras", como preleciona Pinto Ferreira. ${ }^{354}$

A consulta aos Anais da Constituinte, como não poderia deixar de ser, é altamente elucidativa a respeito.

$\mathrm{Na}$ sessão de votação em segundo turno do texto final da Constituição, na 337 . Sessão da Assembléia, realizada em 31 de agosto de 1988, foram

\footnotetext{
${ }^{351}$ Manoel Gonçalves Ferreira Filho, Do Processo Legislativo, 3a. ed., p. 282 (tb. 6a . ed., pp. 291292); Ives Gandra da Silva Martins e Celso Ribeiro Bastos, Comentários à Constituição Brasileira, v. 7, 1995, p. 518; Pinto Ferreira, Comentários à Constituição Brasileira, v. 7, 1995, pp. 517-518.

${ }^{352}$ Adriano Pilatti registra a pressa com que foram realizadas as últimas votações, quando os constituintes já não escondiam o cansaço, e também se mostravam preocupados com a "proximidade crescente de eleições que tornavam constrangedoras certas opções em votos nominais" ( $A$ Constituinte de 1987-1988, cit., p. 315).

${ }^{353}$ Do Processo Legislativo, $3^{\text {a }}$. ed., p. 282 (tb. $6^{\text {a }}$. ed., p. 291). Essa impressão era corrente na época, mesmo antes do encerramento dos trabalhos da Assembléia, como se pode ver no artigo do jornalista Villas-Bôas Corrêa, cujo título é auto-explicativo ("Constituição nasce para vida breve" - Jornal do Brasil, 8.5.1988, citado por Pilatti, A Constituinte de 1987-1988, p. 1).
}

${ }^{354}$ Comentários, cit., vol. 7, p. 517. 
debatidas propostas de modificação do art. $2^{\circ}$.,- Emendas 361, 448 e 492 - todas com o objetivo de retirar a consulta quanto à forma de governo (monárquica ou republicana), mantendo-a apenas quanto ao sistema de governo (presidencialista ou parlamentarista).

Nos debates havidos naquela sessão (destacando-se as intervenções dos constituintes Bocayuva Cunha, Cunha Bueno e do relator Bernardo Cabral), nenhuma relação foi estabelecida entre a proposta de plebiscito e a revisão constitucional, que seria votada daí a instantes. As citadas emendas foram rejeitadas por 344 votos, contra 67 pela sua aprovação e apenas três abstenções.

Quanto à votação final do art. $3^{\circ}$., foram retiradas por seus autores as emendas que objetivavam sua supressão pura e simples - sinal de que o Plenário alcançara consenso quanto à confirmação do dispositivo. Restou somente a Emenda n. 1763, mencionada pelo ministro Néri da Silveira, também retirada, após decisiva intervenção do constituinte Nelson Carneiro, assegurando que a revisão somente poderia ocorrer uma única vez, sem necessidade de previsão expressa. O relator Bernardo Cabral disse, em seguida, que "ficará registrado nos Anais da Casa o que se deseja” (isto é, que a revisão com quórum facilitado ocorreria uma única vez). Assentiu o próprio presidente Ulysses Guimarães, dirigindo-se ao constituinte Darcy Deitos, autor do destaque: "Parece que, pelos debates, a intenção de V. Exa. foi atingida”. 355

Vê-se que os próprios constituintes tinham plena consciência de que a motivação de seus votos ficaria registrada para futuras consultas, com vistas ao esclarecimento do real sentido do texto constitucional. Compilaram e publicaram todos esses registros exatamente para que fossem consultados. ${ }^{356}$

Em 22 de setembro de 1988, às vésperas da promulgação e quando já haviam se encerrado as votações, o constituinte Arnaldo Faria de Sá fez, na tribuna, uma declaração que bem resumia o estado de espírito então reinante: “ $A$

\footnotetext{
${ }^{355}$ Diário da da Assembléia Nacional Constituinte, ano II, n. 305, ed. 1.9.88, pp. 486-490.

${ }^{356}$ Hoje, disponíveis até na internet, nos endereços eletrônicos da Câmara dos Deputados e do Senado Federal.
} 
Carta merecerá muitas críticas daqueles que entendem que deve ser mudada, alterada. Esses terão tempo de fazê-lo na próxima revisão constitucional. ${ }^{, 357}$

Embora importantíssima, ainda que muitas vezes negligenciada, a consulta a esses Anais não é a única forma de pesquisar o pensamento reinante no momento em que promulgada a Constituição (o que abarca não só a intenção dos constituintes, mas também o entendimento original da Constituição pela sociedade). No famoso e tantas vezes publicado discurso de promulgação da nova Carta, Ulisses Guimarães reconheceu: "Não é a Constituição perfeita. Se fosse perfeita, seria irreformável. Ela própria, com humildade e realismo, admite ser emendada, até por maioria mais acessível, dentro de cinco anos". 358

Desse modo, estando bem caracterizado o histórico de cada uma das normas, cremos que não haverá nenhuma dificuldade em responder à indagação feita por Cármen Lúcia Antunes Rocha, mencionada ao início deste tópico. Por que aceitar "uma revisão facilitada", supostamente "fragilizadora" da Constituição? Singelamente, por um único e bastante motivo: porque essa foi a decisão do constituinte, reafirmada em termos inequívocos pelo próprio presidente da Assembléia, no ato da promulgação.

Qualquer pessoa que tenha vivido aquela época - ou que tenha buscado se informar, com o espírito livre e sem idéias preconcebidas, acerca das reais circunstâncias daquele momento - não terá nenhuma dúvida em reconhecer que a "humildade" e o "realismo" que levaram à previsão de reforma "por maioria mais acessível, dentro de cinco anos", não diziam respeito somente aos pontos sujeitos à consulta plebiscitária. A constituinte refletira a profunda divisão da sociedade em outros inúmeros assuntos relevantes, e adotara soluções de compromisso, muitas sem perspectiva de longa vigência, na expectativa de que a experiência institucional e o

\footnotetext{
${ }^{357}$ Diário da Assembléia Nacional Constituinte, 23.9.1988, p. 248.

${ }^{358}$ Diário da Assembléia Nacional Constituinte, 5.10.1988, pp.14.380-14382. Disponível em www.senado.gov.br/publicações/anais/constituinte e em diversas outras publicações (p. ex., na História Constitucional do Brasil, de Paulo Bonavides e Paes de Andrade, $3^{\text {a }}$. ed., pp. 921-925; Revista Direito GV, vol. 8, jul-dez.2008, pp. 595-602).
} 
amadurecimento político levassem à formação de amplos consensos, inalcançáveis naquele momento. ${ }^{359}$

Afirmações no sentido de que a revisão foi convocada "única $e$ exclusivamente" para formalizar eventual decisão de reforma advinda do plebiscito ${ }^{360}$ estão completamente dissociadas da realidade, desmentidas enfaticamente pelos registros dos trabalhos da Assembléia Nacional Constituinte e pelos testemunhos dos que participaram daquele processo.

A revisão constitucional de 1993-1994, como sabemos, teve um resultado pífio, e o art. $3^{\circ}$ é agora matéria superada, pois sua eficácia esgotou-se. Mas todo o episódio, com a celeuma então criada, é mais um excelente exemplo do que vimos sustentando: a utilidade da perspectiva originalista para, fazendo respeitar a intenção discernível do constituinte, evitar que prosperem interpretações politicamente orientadas.

\subsection{A questão dos efeitos do Mandado de Injunção}

\subsubsection{Colocação da controvérsia}

Desde o início da vigência da Carta de 1988, como se sabe, existe a contenda doutrinária quanto aos efeitos da decisão proferida em mandado de injunção $\left(\mathrm{CF}\right.$, art. $5^{\circ}$, inciso LXXI). As várias correntes a esse respeito são divididas por Alexandre de Moraes em dois grandes grupos ou posições: a) concretista e b) não concretista.

\footnotetext{
${ }^{359}$ Dois exemplos desse amadurecimento da sociedade: as restrições ao capital estrangeiro e a limitação das taxas de juros bancários, previstas na redação original da Constituição (arts. 171 e 192, $\S 3^{\circ}$.) e objeto de acalorados debates, à época da promulgação, alguns anos mais tarde foram revogadas sem maiores divergências (EC 6/1995 e EC 40/2003).

${ }^{360}$ Valmir Pontes Filho, Curso Fundamental de Direito Constitucional, cit., p. . 96; Paulo Bonavides, A Constituição Aberta, cit., pp. 84 e 91.
} 
No primeiro caso, reconhecida a omissão legislativa ou administrativa, caberia ao órgão judiciário implementar desde logo o exercício do direito, da liberdade ou da prerrogativa constitucional, enquanto não haja a necessária regulamentação; essa concretização do direito tanto pode ser válida erga omnes (posição concretista geral) como apenas para o autor do mandado (posição concretista individual). Esta última hipótese ainda comporta duas variantes, podendo ser direta (quando a implementação ocorrer imediatamente, bastando a decisão de procedência do mandado) ou intermediária (quando é assinalado um prazo para que a omissão seja sanada, com a edição da norma ou do ato regulamentar faltante).

A posição não concretista, por sua vez, consiste em “atribuir ao mandado de injunção a finalidade específica de ensejar o reconhecimento formal da inércia do Poder Público", limitando-se o tribunal a dar "ciência ao poder competente para que edite a norma faltante". 361

O ponto que particularmente nos interessa, neste trabalho, é a presença da argumentação originalista tanto para a defesa da posição concretista, como também - e com ainda maior ênfase - na fundamentação adotada pelo Supremo Tribunal Federal em favor da posição não concretista, a partir do histórico julgamento do Mandado de Injunção 107, em 1989. Posição, aliás, que permaneceu majoritária no STF até 2007 (com algumas exceções), mais precisamente até o julgamento do Mandado de Injunção 108, quando o Tribunal acolheu a posição concretista geral. ${ }^{362}$

O que procuraremos demonstrar, em suma, é que no grande debate a respeito desse instituto - uma das mais significativas inovações da atual Constituição - a argumentação envolvendo a intenção do constituinte e o histórico da criação da norma constitucional assumiu excepcional relevo, sendo utilizada tanto em defesa das duas posições antagônicas.

\footnotetext{
${ }^{361}$ Alexandre de Moraes, Direito Constitucional, Atlas, 24‥ ed., pp. 175-181.

${ }^{362}$ Alexandre de Moraes, ob. cit., p. 179.
} 


\subsubsection{A intenção do constituinte como argumento dos concretistas}

Defensor da eficácia concreta, levando à "outorga direta do direito reclamado", José Afonso da Silva oferece em abono de sua tese o pormenorizado relato da elaboração da norma constitucional, reveladora, segundo ele, da "preocupação do constituinte" em criar "meios para eficácia imediata das normas constitucionais". Nesse sentido, menciona a $3^{\mathrm{a}}$. reunião da Subcomissão dos Direitos Políticos, dos Direitos Coletivos e e Garantias, ocorrida em 22.4.87, - na qual o deputado Gastone Righi defende a criação de "uma forma de processo pela qual alguém possa exercitar um direito social". A sugestão prospera:

"O Constituinte Lysâneas Maciel propõe dois mecanismos: um na forma reclamada pelo Constituinte Gastone Righi, no art. $3^{\circ}$. do seu Anteprojeto, segundo o qual o povo exerceria a soberania: VII pelo mandado de garantia social por inexistência ou omissão de normas, atos jurisdicionais ou administrativos; o outro no art. 40: "Na falta de regulamentação para tornar eficaz a norma constitucional, o Ministério Público ou qualquer interessado poderá requerer ao Judiciário a aplicação do direito assegurado". Aqui está delineado o mandado de injunção (...)".363

Há outras sugestões nesse sentido, como a de n. 367-1, do constituinte Ruy Bacelar, do seguinte teor:

"Art. Os direitos conferidos por esta Constituição e que dependam da lei ou de providências do Estado serão assegurados por mandado de injunção, no caso de omissão do Poder Público. Parágrafo único. $\mathrm{O}$ mandado de injunção terá o mesmo rito processual estabelecido para o mandado de segurança".

${ }^{363}$ Curso de Direito Constitucional Positivo, 6 ${ }^{\text {a }}$ ed., 1990, p. 389, nota 65. Os destaques são do original. 
O relator da Subcomissão dos Direitos Individuais e Garantias, deputado Darcy Pozza, acolhe a sugestão de Ruy Bacelar e declara, na sessão de 26 de maio de 1987 , que

"no rol dos Direitos e Garantias Individuais, ao lado do Mandado de Segurança, como instrumento de defesa dos interesses do cidadão, incluímos o Mandado de Injunção, visando permitir que a letra constitucional, à falta de Lei Complementar ou Ordinária que a regulamente, se torne realmente auto-aplicável". ${ }^{364}$

O anteprojeto dessa Subcomissão, redigido num único artigo, contemplava, no parágrafo 37 :

“Conceder-se-á mandado de injunção, observado o rito processual estabelecido para o mandado de segurança, a fim de garantir direitos assegurados nesta Constituição, não aplicados em razão da ausência de norma regulamentadora, podendo ser requerido em qualquer juízo ou tribunal, observadas as regras de competência da lei processual”.

Para José Afonso da Silva, a proposta dessa Subcomissão não teria sido substancialmente alterada na respectiva Comissão temática ${ }^{365}$, e também "contemplou o remédio com aquele sentido de tornar eficaz, in concreto, direitos garantidos na Constituição".

Todavia, mesmo após as modificações nas fases posteriores do processo constituinte, que resultaram na redação do art. $5^{\circ}$., inciso LXXI da Constituição, tal como entrou em vigor, José Afonso da Silva continua a sustentar: “Todo o pensamento constituinte foi no sentido de estruturar um instrumento para

\footnotetext{
${ }^{364}$ Os destaques são nossos.

${ }^{365}$ Veremos, no item seguinte, que as alterações então efetuadas ensejaram graves conseqüências.
} 
assegurar imediatamente os direitos, liberdades e prerrogativas, na falta de regulamentação".366

Em linhas gerais, Elival da Silva Ramos parece concordar que esse teria sido o intuito dos elaboradores da Carta: "o Constituinte pretendeu que os direitos fundamentais, sempre que possível, pudessem ser imediatamente exercidos" 367

\subsubsection{O argumento histórico na defesa da posição não concretista}

Ponto muito interessante, porém, e que não tem merecido o devido destaque, é o fato de que a polêmica orientação adotada pelo Supremo Tribunal Federal, no Mandado de Injunção 307 (ou seja, a eficácia meramente declaratória da injunção, com a comunicação da mora legislativa ao Congresso) também teve significativo embasamento no processo de elaboração da norma.

Em primeiro lugar, registre-se que a primeira proposta de criação do mandado de injunção trazia-o conjugado ao conceito de inconstitucionalidade por omissão. É o que consta expressamente da Sugestão n. 155-4, de 27.3.1987, de autoria do Senador Virgílio Távora e do Deputado Carlos Virgílio: "Sempre que se caracterizar a inconstitucionalidade por omissão, conceder-se-á mandado de injunção, observado o rito processual estabelecido para o mandado de segurança."

E a justificação apresentada pelo Senador Virgílio Távora também tratava os dois institutos como indissoluvelmente ligados:

\footnotetext{
366 Ob. cit., pp. 389-390, nota 65.

${ }^{367}$ Controle de Constitucionalidade no Brasil, p.321.
} 
"Visando efetivar a produção de direitos públicos subjetivos criados, de forma genérica, pela Constituição, os quais se não implementados pelos poderes constituídos, mediante a edição de atos e normas integrativas da Carta Magna, ensejarão a inconstitucionalidade por omissão, submetemos à apreciação da Comissão Temática pertinente a previsão normativa do instituto processual do mandado de injunção, como garantia constitucional. "368

$\mathrm{Na}$ mesma data, os referidos constituintes apresentavam, como complemento à anterior, a Sugestão n. 156-2, propondo a inclusão, nas Disposições Gerais e Transitórias, de dispositivo definindo a inconstitucionalidade por omissão como decorrente da "não-edição de atos ou normas pelos Poderes Legislativo, Executivo e Judiciário, visando implementar esta Constituição", fazendo constar, na respectiva justificação, que "o remédio jurídico-constitucional para coibi-la" haveria de ser o mandado de injunção, conforme proposta anterior, "que a esta complementa". 369

Mas Jorge Hage, após resgatar toda a tramitação dessas propostas na Constituinte, sagazmente aponta que foi na Comissão da Soberania e dos Direitos e Garantias do Homem e da Mulher, "que a boa e clara redação vinda da Subcomissão começou a sofrer alterações profundas, que lhe retiraram a clareza e que culminariam, mais tarde, na redação final, por ensejar a polêmica que até hoje persiste no âmbito do STF”. ${ }^{370}$

Foi do seguinte teor o substitutivo do relator José Paulo Bisol, aprovado pela referida Comissão:

“Art. 34. Conceder-se-á mandado de injunção, observado o rito processual do mandado de segurança, sempre que a

\footnotetext{
${ }^{368}$ Diário da Assembléia Nacional Constituinte, 29.4.87, Suplemento, p. 99.

${ }^{369}$ Diário da Assembléia Nacional Constituinte, 29.4.87, Suplemento, pp. 99-100.

${ }^{370}$ Omissão Inconstitucional e Direito Subjetivo, 1999, p. 125.
} 
falta de norma regulamentadora torne inviável o exercício dos direitos e das prerrogativas inerentes à nacionalidade, à soberania do povo e à cidadania.

Art. $48, \S 1^{\circ}$. A lacuna permanecendo depois de seis meses da promulgação da Constituição, qualquer cidadão, associação, partido político, sindicato ou entidade civil poderá promover mandado de injunção para o efeito de obrigar o Congresso a legislar sobre o assunto no prazo que a sentença consignar."

Não escaparam a Jorge Hage dois problemas capitais desse texto: a inexplicável "supressão das regras sobre a competência", que constavam da proposta vinda da Subcomissão (v. item anterior), e "a confusão entre Mandado de Injunção e Ação Direta de Inconstitucionalidade" ${ }^{371}$, retornando-se, pois, à mesma situação prevista nas sugestões dos constituintes Virgílio Távora e Carlos Virgílio, logo ao início dos trabalhos da Assembléia.

Essa ligação umbilical entre os dois institutos acabou por ser aprofundada na Comissão de Sistematização, com uma sutil modificação do critério definidor da competência do STF e do STJ. Ao Supremo Tribunal Federal ela foi atribuída quando a norma regulamentadora reclamada for de responsabilidade do Presidente da República, do Congresso Nacional (incluindo cada uma das Casas, ou as respectivas Mesas), do Tribunal de Contas da União, dos Tribunais Superiores ou do próprio Supremo Tribunal Federal (CF, art. 102, inc. I, q). Ao Superior Tribunal de Justiça restou a competência para julgar os mandados de injunção quando a elaboração de norma regulamentadora for de responsabilidade de órgãos, entidades ou autoridades federais, ressalvada a competência “dos órgãos da Justiça Militar, da Justiça Eleitoral, da Justiça do Trabalho e da Justiça Federal", bem como, por óbvio, do Supremo Tribunal Federal (art. 109, inc. I, $h$ ).

Note-se que, embora não prevista a competência dos Tribunais Regionais Federais (CF, arts. 108 e 109), ela está mencionada no caso dos Tribunais Regionais Eleitorais (art. 121, § inc. V).

${ }^{371}$ Omissão Inconstitucional e Direito Subjetivo, cit., p. 126. Poderíamos acrescentar uma terceira crítica, certamente menos importante, quanto à descuidada técnica de redação do segundo dispositivo. 
Procurando entender o conjunto dessas disposições, Uadi Lammêgo Boulos diz que o "o intuito do constituinte foi claro: concentrar nas mãos dos tribunais o poder decisório, com vistas e uniformizar critérios para colmatar lacunas, evitando decisões conflitantes em mandados de injunção". ${ }^{372}$

Mas o ponto mais relevante para nossa exposição está na fundamentação utilizada pelo Supremo Tribunal no leading case a respeito da matéria: a Questão de Ordem no Mandado de Injunção n. 107, julgada em 23 de novembro de 1989.

Tratava-se de mandado de injunção ajuizado por um Oficial do Exército contra o Presidente da República, reclamando que a falta de regulamentação das condições de transferência para a inatividade, prevista no art. $42, \S 9^{\circ}$ da Constituição Federal, tornava inviável a sua permanência no serviço ativo. O mandado acabou não sendo conhecido, por entender o Tribunal que faltava ao autor o requisito da legitimidade ativa (julgamento em 21.11.1990).

A importância do caso não está nesse desfecho inglório, mas na Questão de Ordem levantada pelo relator, ministro Moreira Alves, um ano antes.

Nesse incidente prévio, propunha-se ao Tribunal dirimir dúvidas quanto à auto-aplicabilidade do dispositivo constitucional instituidor do mandado de injunção, e bem assim quanto ao alcance da decisão a ser tomada. Para tanto, o relator foi ao processo de elaboração da norma, detendo-se nas modificações ocorridas na Comissão de Sistematização. No chamado Projeto A era prevista "ação de inconstitucionalidade contra ato que, por ação ou omissão, fira preceito desta Constituição" (art. $6^{\circ}$., $§ 55$ ); e o mandado de injunção voltava-se "contra atos do Presidente da República, do Primeiro-Ministro, das Mesas da Câmara dos Deputados e do Senado Federal, do Tribunal de Contas da União, do Procurador-Geral da República, do Superior Tribunal de Justiça e do próprio Supremo Tribunal Federal" (STF, art. 126, I, d), “contra ato de Ministro de Estado ou do próprio Tribunal" (STJ, art. 129, I b), “contra ato do próprio Tribunal ou de Juiz Federal” (TRFs, art. 132, I, c), "contra ato de autoridade federal, excetuados os casos de competência dos tribunais federais" (competência dos juízes federais, art. 133, VIII).

${ }^{372}$ Curso de Direito Constitucional, 5a . ed., 2010, p. 763. 
No Projeto B já não mais constava o art. $6^{\circ}$., $§ 55$, e na votação final, em setembro de 1988, os demais dispositivos acima citados foram substituídos pelos atualmente constantes da Carta Magna.

A falta de menção expressa quanto aos efeitos da decisão, e o estabelecimento do critério o ratione personae para definição da competência dos Tribunais Superiores (não mais em razão de atos, mas apenas da omissão), levaram o ministro Moreira Alves a buscar a solução do impasse no preceito relativo à inconstitucionalidade por omissão - o que era justificável, em vista do tratamento similar desses institutos ao longo do processo constituinte. Concluiu o eminente relator:

“...se o próprio Supremo Tribunal Federal, na ação direta de inconstitucionalidade, não pode, como decorre de texto constitucional expresso, suprir, ainda que provisoriamente, a omissão constitucional de qualquer Poder, órgão, entidade ou autoridade a que incumbe elaborar norma regulamentadora, direta ou indiretamente, de texto constitucional que verse direitos, garantias e prerrogativas a que alude o art. $5^{\circ}$., LXXI, da Constituição - o que, como já se viu, era expressamente admitido no Primeiro Substitutivo da Comissão de Sistematização, e foi, afinal, substituído pela 'ciência ao Poder competente para a adoção das providências necessárias' -, resulta daí, logicamente, que não poderá ele, em mandado de injunção em que o autor - ao contrário do que sucede na ação direta de inconstitucionalidade - não defende interesse público, mas interesse individual, regulamentar texto constitucional genericamente (para os que entendem que sua decisão tem eficácia erga omnes), ou até para o caso concreto, pois, ainda nessa hipótese, haverá uma regulamentação que - admitido o mandado de injunção coletivo - poderá abarcar todos os destinatários da norma, ou boa parte deles. Aliás, a admitir-se essa regulamentação, ter-se-á esse absurdo: o que o Supremo Tribunal Federal não poderá fazer em ação direta de inconstitucionalidade por omissão, Órgão Judiciário inferior a ele - assim, os Tribunais Superiores ou os Tribunais Regionais - poderá fazê-lo, em mandado de injunção". 
Ainda no julgamento dessa Questão de Ordem, também o ministro Sepúlveda Pertence incursionou longamente no processo de elaboração normativa, esclarecendo que a alteração das regras de competência, na "undécima hora do processo constituinte", levou-o a modificar seu entendimento inicial, precisamente sobre o alcance da decisão a ser proferida em mandado de injunção:

“ (...) meu convencimento (....) que, confesso, se inverteu a partir do acompanhamento da saga do mandado de injunção, desde as discussões pré-constituintes e passando por todo o trabalho da Assembléia Constituinte.

3. De fato. Durante a elaboração constituinte, sempre me pareceu que a idéia do mandado de injunção se endereçava a coisa diversa, não à sentença, que estamos chamando de mandamental neste debate, mas efetivamente a dar solução ao caso concreto em que a eficácia de um direito constitucional estivesse paralisada por omissão de norma inferior regulamentadora de seu exercício. (...)

10. Na Assembléia Constituinte, creio que, até o texto votado no segundo turno - e o eminente relator o mostrou -, prevaleceu esta vocação do mandado de injunção, ou dos vários nomes que a princípio se lhe deram, para construir a solução do caso singular, viabilizando, para o impetrante, o exercício do direito paralisado, à espera da norma infraconstitucional regulamentadora. Ao passo que a ação direta de inconstitucionalidade por omissão visava, sim, nos sucessivos anteprojetos e projetos da Assembléia, a induzir à colmatação da lacuna regulamentar da Constituição, o mandado de injunção foi pensado, repito, para construir a solução integradora, no caso concreto.

11. Expressivo, aliás, deste pensamento, desta destinação, são dois nomes propostos para o instituto: um, da emenda do Senador Lavoisier Maia, que o chamava, significativamente, 'mandado de concretização', e outro, do nobre Deputado Aluísio Chaves, 'mandado de integração': neles, ficava evidente este propósito de solução do caso concreto, de implementação, hic et nunc, do direito constitucional, por obra do juiz. 
12. Mas essa linha sofreu, na undécima hora do processo constituinte, uma ruptura ainda inexplicada, que desde o início me levou à perplexidade: a do sistema de competência, que se alterou, repito, na redação final da Constituição (...)

14. Ora, até o segundo turno, se previa a competência do Supremo Tribunal para mandado de injunção contra atos ou omissões do Presidente da República e, significativamente, das Mesas do Congresso Nacional e não do próprio Congresso Nacional, a mostrar bem que o que determinava a competência do Supremo era o ato concreto dessas autoridades, sujeitas imediatamente à sua jurisdição, que negasse o direito constitucional reclamado (...)

16. Na redação final, entretanto, repito a ênfase que lhe deu o eminente Relator, o art. 102 manda determinar a competência do Supremo Tribunal pela hierarquia do órgão competente para edição da norma necessária ao exercício do direito."

A consequência lógica dessa mudança de competência seria, na visão de Pertence, a atribuição ao Supremo do poder de fixação da norma faltante, com eficácia erga omnes. Todavia, como o constituinte sabidamente não deu esse passo adiante, não via como o Supremo pudesse fazê-lo, reconhecendo a existência de "um empecilho na lealdade política, que a interpretação jurisdicional deve, às inspirações $e$ às decisões políticas fundamentais da Constituição interpretada". E isto porque - e aqui um ponto fundamental desse magnífico voto - "não é possível fazer abstração de um dado histórico da elaboração constitucional”.

O ministro Pertence ainda salientou que não podia reconhecer ao Supremo um poder de suprir a omissão normativa, uma vez que essa solução havia sido expressamente analisada, porém rejeitada pelos constituintes:

“26. Essa questão, repito, foi posta perante a Assembléia Nacional Constituinte. Lembro-me do anteprojeto do nobre Deputado Egídio Ferreira Lima, Relator da Comissão dos Poderes, no qual se estatuía que, declarada a omissão, na ação direta, o Supremo Tribunal assinaria prazo ao Poder competente e, exaurido esse prazo, supriria, 
mediante resolução, a omissão normativa com eficácia de lei, se fosse o caso.

27. Ora, esse poder normativo do Supremo Tribunal, proposto e aprovado nos primeiros passos da Assembléia Nacional Constituinte, veio a ser suprimido, a partir da Comissão de Sistematização e não logrou voltar ao texto constitucional. Tratou-se de uma decisão política da Assembléia Constituinte."

E a seguir, antecipando uma resposta às muitas críticas que essa decisão ocasionou, assinalou o ministro que se enganavam os que pretendiam "colocar todo o problema da efetividade da Constituição como uma conseqüência da opção sobre a natureza jurídica do mandado de injunção". Acreditar que "por decisão judicial, se pudesse dar, de fato, efetividade concreta a todos os avanços de uma Constituição (...) é, na verdade, ilusionismo político, no mínimo".

Em outra antológica passagem, na qual nos adverte quanto aos limites da atuação judicial em um Estado de Direito, organizado a partir das vigas mestras da democracia e da divisão funcional do Poder, proclama o ministro Pertence ser impróprio

"exigir do Poder Judiciário o que ele não pode dar sob esta ou aquela forma processual, porque são conquistas, são avanços que dependem necessariamente do jogo político, em particular, da tensão entre pressões contraditórias da sociedade civil sobre os órgãos de definição das prioridades da ação estatal; dependem, enfim, da ambiência de lutas e pressões contrapostas, que é ambiência de uma democracia." ${ }^{\prime 373}$

Também o ministro Aldir Passarinho referiu-se expressamente "às modificações que o instituto foi sofrendo no curso do processo constituinte", reduzindo "a extraordinária amplitude que lhe foi dada inicialmente",sendo que as normas afinal aprovadas "não estipulam nem que seja fixado prazo para o expedição da norma

\footnotetext{
${ }^{373}$ Item n. 31 do voto citado.
} 
omitida, nem que o órgão judicial a expeça, ele mesmo, suprindo a omissão", em vista do princípio da separação de poderes.

A Questão de Ordem foi acolhida por unanimidade, nos termos propostos pelo relator. ${ }^{374}$

Concluímos que essa importantíssima decisão do Supremo Tribunal Federal - independentemente de concordar-se ou não com a solução adotada resultou de uma inteligente conjugação da interpretação histórica e originalista com o método lógico-sistemático, em que uma profunda análise do processo constituinte não dispensou o exame dos textos normativos em suas recíprocas implicações.

\subsection{Conceito de veículo automotor para fins tributários}

No julgamento do Recurso Extraordinário n. 134.509-8, o Supremo Tribunal valeu-se do elemento histórico para interpretar o art. 155, inciso I, alínea "c" da Constituição Federal.

Esse dispositivo autoriza os estados a instituir imposto sobre a propriedade de veículos automotores. E o estado do Amazonas, com base nessa competência, editou lei fazendo incidir o IPVA sobre embarcações e aeronaves, por considerá-las abrangidas naquele conceito.

O relator sorteado na Segunda Turma, ministro Marco Aurélio, aceitou essa argumentação, basicamente assinalando, em sintonia com a lição de José Cretella Júnior, que veículo automotor é todo aquele “impulsionado por maquinismo interno (...) servindo para o transporte de pessoas, bens ou produtos de natureza terrestre, hídrica ou aérea”. Frisou ainda o ministro que seria razoável esperar que o

\footnotetext{
${ }^{374}$ Acompanharam integralmente o voto do relator os ministros Néri da Silveira (presidente), Aldir Passarinho, Sydney Sanches, Octávio Gallotti, Carlos Madeira, Célio Borja, Paulo Brossard, Sepúlveda Pertence e Celso de Mello. Não participou do julgamento o ministro Francisco Rezek.
} 
constituinte, se quisesse restringir o conceito, o teria feito expressamente (voto proferido em 8.9.1994).

Assim não pareceu, todavia, ao ministro Francisco Rezek. Lembrando que a mesma questão chegara a ser posta perante o Supremo Tribunal Federal, ainda na vigência da Constituição anterior, em representação que não chegara a ser julgada. Na ocasião, parecer do (então) Procurador da República Moacir Antonio Machado da Silva salientava que o IPVA sucedera a Taxa Rodoviária Única, e todos os estados que o haviam instituído limitaram sua incidência aos veículos terrestres. No mesmo sentido veio, após, a Emenda Constitucional n. 27/85, dispondo que metade do produto da arrecadação desse imposto constituiria receita do município onde estivesse licenciado o veículo.

Teceu então o ministro Rezek as seguintes considerações:

“Tentei saber, mediante pesquisa sobre a realidade objetiva, o que está acontecendo, qual a trajetória histórica da norma (...) Verifiquei que temos neste caso um imposto que, na trajetória constitucional do Brasil, sucede à Taxa Rodoviária Única, e não me pareceu, examinados os sucessivos textos constitucionais recentes que, em qualquer momento, tenha sido intenção do constituinte brasileiro autorizar aos Estados, sob o pálio do imposto sobre propriedade de veículos automotores, a cobrança sobre a propriedade de aeronaves e de embarcações de qualquer calado. Os conhecedores do modo nacional de se produzirem textos constitucionais hão de perguntar-se sempre se o constituinte, caso quisesse que o legatário da velha e conhecida Taxa Rodoviária Única se tornasse um imposto capaz de alcançar aviões e navios, teria se omitido de fazer referência a embarcações e aeronaves"

Prosseguiu o ministro Rezek aduzindo que, no caso, não bastaria a interpretação gramatical ou etimológica, pois "veículos automotores" tanto poderia significar navios e aeronaves como, indo um pouco mais adiante, até mesmo animais 
utilizados para transporte de coisas. Em problemas dessa natureza, em que um imposto sucede a outro, não bastaria a análise literal: era indispensável pesquisar os antecedentes históricos, inclusive "no âmbito dos trabalhos preparatórios do texto constitucional a indicar uma intenção de mudança".

E, na sequência, insistiu na indispensabilidade de se levar em conta o elemento histórico, a partir dos trabalhos preparatórios, na exata medida em que capazes de demonstrar a real intenção do constituinte:

"Se um imposto singelamente sucede a outro, o que existe, no registro dos trabalhos preparatórios do novo texto, a evidenciar que o constituinte derradeiro resolveu, de algum modo, aumentar ou restringir o escopo tradicional de determinado imposto?"

Em linha similar à do entendimento original, salientou o ministro Rezek que as autoridades federais responsáveis pela navegação aérea e marítima, ao tempo da promulgação da Emenda Constitucional 27/85, estavam convictas de que o IPVA não se aplicava à propriedade de barcos e aeronaves. ${ }^{375}$ Esse ponto é muito importante porque, mesmo os poucos Estados que pretendiam cobrar o IPVA nesses casos, não conseguiam fazê-lo,

"pelo singelo motivo de que as autoridades federais competentes, inteiramente hostis à tese de que essa abrangência seja constitucional, não fornecem, a nenhum Estado, dados cadastrais relacionados com navios e com embarcações de qualquer natureza".

Finalizando seu voto, o ministro ainda lembrou que o mandamento constitucional quanto à repartição de metade do produto da arrecadação do IPVA com os municípios em que licenciados os veículos criava uma dificuldade

\footnotetext{
${ }^{375}$ Citando, nesse ponto, "alentado parecer" do Dr. Rui Carlos de Barros Monteiro, na consultoria jurídica do Ministério da Aeronáutica, datado de 1986.
} 
insuperável, a demonstrar o erro da tese que estava a combater, pois não havia - como ainda hoje não há - registro algum que vincule navios e aeronaves a municípios.

O pensamento esposado pelo ministro Rezek prevaleceu no plenário do Tribunal, para o qual o julgamento foi afetado, em vista da repercussão da matéria, ficando vencido o ministro Marco Aurélio (sessão de 29.5.2002).

Tratou-se, em resumo, de notável afirmação da importância do elemento histórico na interpretação constitucional, especialmente no que diz respeito à verificação do registro dos trabalhos preparatórios, reveladores da intenção do constituinte.

\subsection{Conceito constitucional de racismo}

O julgamento do Habeas Corpus n. 82.424-RS, que se estendeu por cinco sessões plenárias, de 12 de dezembro de 2002 a 19 de setembro de 2003, foi um dos casos de maior repercussão na história do Supremo Tribunal Federal, em que foi analisada a condenação pelo crime de racismo, proferida pelo Tribunal de Justiça do Rio Grande do Sul, contra autor, editor e divulgador de livros considerados antissemitas.

O caso envolveu a análise de diversos e importantes temas, tais como os limites da liberdade de expressão, a imprescritibilidade em matéria penal, a possibilidade de aprofundamento no exame da prova em sede de habeas corpus, a denegação da ordem em relação a fundamento não invocado pelo impetrante, além de extensas incursões em direito comparado e estudos de história e antropologia. 
Interessa-nos aqui, unicamente, a polêmica que se estabeleceu em relação ao conceito de racismo, que a Constituição declarou constituir "crime inafiançável e imprescritível, sujeito à pena de reclusão, nos termos da lei” (art. 5º, inciso XLII).

A questão logo foi identificada como central para o deslinde da controvérsia, diante do argumento do relator sorteado, ministro Moreira Alves, de que os judeus não constituíam uma raça; assim, eventual discriminação ou preconceito contra eles poderia configurar conduta criminosa, não se caracterizando, porém, como racismo.

O Tribunal, após acalorados debates, inclinou-se pela tese de que, embora não existam propriamente raças, mas apenas uma única raça humana, o conceito de racismo deveria ser construído mediante a conjugação de fatores e circunstâncias históricas, políticas e sociais, abrangendo quaisquer atos de discriminação contra grupos humanos considerados, sob qualquer pretexto, como "inferiores".

Nesse sentido, por exemplo, pronunciou-se o ministro Gilmar Mendes: embora raça seja um "conceito pseudocientífico notoriamente superado", devem ser consideradas racistas "aquelas manifestações discriminatórias assentes em referências de índole racial (cor, religião, aspectos étnicos, nacionalidade, etc.)”. Ou, como sustentou o ministro Celso de Mello, "a noção de racismo" não se resume a aspectos estritamente antropológicos ou biológicos, assumindo uma "dimensão abertamente cultural e sociológica".

No entanto, três votos nesse emblemático julgamento enveredaram pelo exame da intenção dos constituintes para delimitar o real significado do termo racismo.

O primeiro a fazê-lo foi o ministro Moreira Alves, esclarecendo que o elemento histórico era “importante na interpretação da Constituição, quando ainda não há, no tempo, distância bastante para interpretação evolutiva que, por circunstâncias novas, conduza a sentido diverso do que decorre dele”. 
Explicava, a seguir, que perante a Constituição o conceito de racismo estava ligado ao preconceito ou discriminação, "mais especificamente contra a raça negra". E, para demonstrá-lo, foi à origem do dispositivo - Emenda Aditiva 2P00654-0, apresentada em 12 de janeiro de 1988 pelo constituinte Carlos Alberto Caó - transcrevendo sua justificativa:

"Passados praticamente cem anos da data da abolição, ainda não se completou a revolução política deflagrada e iniciada em 1888. Pois impera no País diferentes formas de discriminação racial, velada ou ostensiva, que afetam mais da metade da população brasileira constituída de negros ou descendentes de negros, privados do exercício da cidadania em sua plenitude. Como a prática do racismo equivale à decretação de morte civil, urge transformá-lo em crime".

A seguir, o ministro transcreveu discurso feito pelo autor da emenda, em 3 de fevereiro de 1988, no plenário da Assembléia Nacional Constituinte, em que também ficava clara a referência à raça negra:

"Ocupamos de novo a tribuna do Congresso Nacional Constituinte para discutir uma questão de extrema importância para a construção do estado democrático em nosso País.

Nós somos apenas formalmente os autores desta emenda. Na sua co-autoria tivemos a honra e o prazer de contar com a Constituinte Benedita da Silva. Mas, na verdade, Sr. Presidente, são autores material e substantivamente desta emenda mais de 60 milhões de brasileiros que, geração após geração, secularmente, estão de tal forma submetidos que lhes tem sido recusado aquele direito elementar, o direito à cidadania. É em nome desses milhões de brasileiros, é em nome da nossa Nação brasileira que nós pretendemos falar aos corações, às mentes e à reflexão dos Constituintes de todos os partidos (....)

(...) é indispensável que tenhamos conta de que a construção do Estado democrático se inicia pela superação das discriminações raciais, pela superação dessa tentativa de classificar o homem pela cor da pela no mercado de trabalho (...)". 
Prosseguindo nessa linha, o ministro Moreira Alves ainda transcreveu trecho do discurso do constituinte José Lourenço, naquela mesma data, relacionando claramente o racismo ao preconceito contra os negros, mediante invocação de um clássico da literatura brasileira, O Navio Negreiro, de Castro Alves.

E em manifestação adicional, na segunda sessão de julgamento do habeas corpus, o ministro Moreira Alves rejeitou a ampliação do conceito de raça segundo as descobertas a respeito do genoma humano, no ano 2000 (argumento utilizado no voto do ministro Maurício Correa, abrindo dissidência), porque essa novidade científica não podia "ter sido levada em consideração pela Carta Magna de 1988 ao aludir ao preconceito de raça, para se sustentar que só existe uma raça, que é a humana, e que por ser única não daria margem a preconceito racial a que é ínsita a diversidade de raça".

Por isso, prosseguiu o ministro,

"se se der ao termo constitucional racismo a amplitude que agora se pretende dar no sentido de que ele alcança quaisquer grupos humanos com características culturais próprias, vamos ter o crime de racismo como um tipo de conteúdo aberto, uma vez que os grupos humanos com características culturais próprias são inúmeros, e não apenas, além do judaico, o dos curdos, o dos bascos, o dos galegos, o dos ciganos, grupos esses últimos com relação aos quais não há que se falar em holocausto para justificar a imprescritibilidade".

De fato, a Constituição trata separadamente as variadas formas de discriminação, no inciso XLI do art. $5^{\circ}$, e no inciso seguinte é que trata do racismo, somente a este agregando a nota absolutamente excepcional da imprescritibilidade.

Essa passagem foi, a nosso ver, um dos momentos mais importantes do julgamento, pois bem demonstra que a interpretação ampliativa feita pela maioria, atribuindo ao conceito de racismo um conteúdo que nem remotamente podia ser imaginado pelos constituintes, de modo a abarcar qualquer discriminação de 
fundo cultural ou até mesmo religioso, traz o indesejável efeito de banalizar um tratamento penal diferenciado e extremamente severo, que deveria permanecer nos mais estritos limites do texto constitucional. O caráter imprescritível, nas palavras do ministro Moreira Alves, é uma noção que "aberra de nossa tradição jurídica"; é uma "nota esdrúxula", reveladora de "irracionalismo", além de contrária a "todas as razões humanísticas que levaram à prescritibilidade de todos os crimes a ser um valor universal do Direito", na advertência contida nos votos do ministro Sepúlveda Pertence.

O segundo a buscar o sentido original - e vernacular - de racismo na Constituição como um dos fundamentos de seu voto foi o ministro Carlos Ayres Brito. Lê-se, em um dos itens de sua longa exposição:

"51. Neste novo tópico de tentativa de revelação da vontade constitucional, ajuízo que também o termo racismo foi usado em sentido coloquial. Não foi outra a intenção da Lei Maior senão a de pinçar o vocábulo do próprio linguajar corrente da população. Até como condição de facilitada compreensão e cumprimento de um preceito a que ela, Constituição, emprestou a mais forte coatividade". 376

Salientou o ministro Ayres Brito que a delimitação do conteúdo constitucional de racismo não poderia negar " a história mesma do Brasil, toda ela tão discriminadora dos negros que chegou ao cúmulo de fazer da escravidão desses nossos irmãos um instituto jurídico". E invocou, também, “as particularidades do processo constituinte (....) sabido que toda a regração atinente ao racismo se deu por inspiração do Movimento Negro e específica proposta dos deputados federais Carlos Alberto Caó e Benedita da Silva, ambos de pele negra".

Após reiterar que, na "linguagem popular de ontem e de hoje", racismo é "palavra imediata e preponderantemente significativa de preconceito de cor,

\footnotetext{
${ }^{376}$ A maioria, como se sabe, tendeu para conclusão oposta. A posição majoritária do tribunal, em meio a múltiplas teses e argumentos, foi bem resumida pelo ministro Maurício Corrêa, no item 90 de seu voto: "limitar o racismo a simples discriminação de raças, considerado apenas o sentido léxico ou comum do termo, implica a própria negação do princípio da igualdade". Com a máxima vênia, parece maior o perigo inverso: ampliar o racismo a algo que não seja "simples discriminação de raças" coloca em risco o princípio da segurança jurídica e as garantias do cidadão em matéria penal.
} 
e cor negra", asseverou enfaticamente o ministro Ayres Brito, no item 59 de seu voto: "É isto mesmo. Excluir a negritude do raio de aplicabilidade do comando constitucional vedatório do racismo é pensar e sentir a partir de uma realidade que não é a brasileira".

Assinalou ainda o mesmo ministro que "o racismo de que trata a Constituição (...) é termo exigente de um tipo histórico-cultural de interpretação que atenta para a mais viva história do povo", invocando, a respeito, a lição do antropólogo Darcy Ribeiro, para quem "a característica distintiva do racismo brasileiro é que ele não incide sobre a origem racial das pessoas, mas sobre a cor da pele (em O Povo Brasileiro, editora Companhia das Letras, p. 225)", 377

O ministro Marco Aurélio, por sua vez, também palmilhou a mesma seara:

"Assim, mostra-se claro que a previsão do artigo $5^{\circ}$, inciso XLII, da Constituição, referente à imprescritibilidade do crime da prática de racismo, é uma dessas exceções que somente encontra fundamento a partir de uma visão unitária da Carta. Quando da criação do inciso na Assembléia Constituinte, procurava-se combater um comportamento específico reprovável em nossa história. Refirome à discriminação racial, ao preconceito contra o negro. Outra não era a intenção do constituinte quando previu a imprescritibilidade do crime de racismo e quando fez constar esse significado no sistema constitucional."

E para comprovar o que dissera, transcreveu a já citada justificativa da proposição originária, do deputado Carlos Alberto Caó, e ainda

\footnotetext{
${ }^{377} \mathrm{O}$ último destaque é nosso. A citação desses trechos não indica nossa adesão às conclusões do ilustre ministro, que terminou, em descompasso com suas próprias premissas, por diluir o conceito de racismo, além de absolver o paciente, em sede de habeas corpus.
} 
numerosos discursos feitos da tribuna, pelo próprio autor da proposta e pelos deputados Chagas Rodrigues, Benedita da Silva, Haroldo Lima e Sandra Cavalcanti, que pacientemente foi buscar nas Atas da Assembléia Nacional Constituinte, citando de modo preciso as datas em que proferidos e a exata localização nos Anais, para concluir que todos aqueles parlamentares, “ examinando a questão do racismo, pronunciaram-se sem exceção pela reprovação à discriminação contra o negro e pela condenação de sistemas como o do apartheid".

E prosseguiu o ministro Marco Aurélio:

"Não encontrei, na análise dos Anais da Constituinte, qualquer menção, única que fosse, ao povo judeu quando fora discutido o racismo. A explicação, para mim, é evidente. É que a Constituição de 1988 é uma Constituição do povo brasileiro, para ser aplicada ao povo brasileiro e tendente a resolver os nossos próprios problemas. Não há qualquer pronunciamento acerca de racismo contra judeu e, paralelamente, há folhas e mais folhas de manifestações acerca da vedação do racismo contra o negro, pois a Constituição de 1988 não é uma Constituição para o povo alemão, francês, italiano, polonês, austríaco ou o europeu em geral. A Constituição Cidadã - valemo-nos neste momento da visão realista e corajosa de Ulysses Guimarães - visa a dar tratamento aos problemas genuinamente brasileiros, dentro das nossas circunstâncias e segundo a nossa história e cultura. Esse é o valor em que se pautou o constituinte para prescrever exceção tão grave aos direitos fundamentais e tão séria ao regime penal constitucional".

Tão enfática explicitação de argumento tipicamente originalista levou o ministro Marco Aurélio a considerar necessário ressalvar que não estava a 
“defender tese do Direito Constitucional - a meu ver, ultrapassada - por meio da qual se determinava que a interpretação da Constituição deveria partir da intenção dos legisladores originários. Meu pensamento insere-se na lógica que preza por uma compreensão limitativa das exceções constitucionais ao sistema de direitos fundamentais."

Respeitamos a ressalva, mas a linha argumentativa do voto fala por si. Se tratasse apenas de conferir interpretação restritiva a uma regra limitadora de direitos fundamentais, não haveria necessidade de referir minuciosamente cada um dos pronunciamentos feitos na tribuna da Constituinte, citando-os com pormenorizada indicação de datas e páginas dos Anais - sem falar que o tópico já constava de votos anteriores. Ademais, foi o próprio ministro Marco Aurélio que se referiu, em passagem acima transcrita, à "intenção do constituinte" como elemento decisivo para a delimitação do conceito constitucional de racismo.

Assinale-se que dois ministros, embora defendendo a tese exatamente contrária, que acabou por prevalecer, ampliando o conceito de racismo ao ponto de desconectá-lo de sua própria etimologia - uma vez que o tribunal considerou dispensável sua correlação com a idéia de raça - acabaram por aceitar, em dado momento, travar o debate no campo da intenção do legislador, oferecendo seus testemunhos na qualidade de ex-integrantes da Assembléia Constituinte.

O ministro Maurício Corrêa fez tais referências nos itens 2 e 12 de sua manifestação preliminar (sessão de 12.12.2002), bem como nos itens 91 e 92 de seu voto, proferido em 4.4.2003, sendo que neste último, proferido na sessão de 4 de abril de 2003, julgou oportuno afirmar que

"a distinguida referência aos negros nos debates sobre o tema na Assembléia constituinte decorreu da natural dívida da sociedade nacional para com a comunidade negra. Essa constatação empolgou à ocasião as discussões, sem contudo perder o sentido de que a abrangência da inovação na Carta não se reservaria tão-só aos negros, mas também, tinha 
horizontes mais amplos. Por isso, a simpatia que contagiou os constituintes por sua aprovação, como para tanto posso dar o meu testemunho e invoco, se me permite, o do Ministro Nelson Jobim, nós ambos constituintes...”.

E o ministro Nelson Jobim, por sua vez, também considerou necessário abordar o tema por esse ângulo:

"No debate da Constituinte, registrado nos anais, falava-se no negro, mas estavam lá os judeus, estavam lá os homossexuais e tivemos a oportunidade de discutir isso (...) Nunca se pretendeu, com o debate, restringir ao negro".

Várias são as reflexões que suscitam esses comentários.

Embora ambos pretendam afirmar qual teria sido a verdadeira intenção dos constituintes, nota-se a ausência de amparo em dados objetivos ou em manifestações públicas dessa alegada intenção. O segundo chega ao ponto de considerar relevante, para a interpretação do sentido de uma norma constitucional, a mera presença, em plenário, de representantes deste ou daquele grupo. É nítido o contraste em relação ao cuidado que tiveram os ministros Moreira Alves e Marco Aurélio, que buscaram registros concretos, em pronunciamentos e justificativas oficiais.

As afirmações dos ministros Corrêa e Jobim tangenciam, igualmente, perigo que já foi apontado: se o preconceito de natureza cultural também pode caracterizar racismo, a coerência levará a concluir que manifestações preconceituosas ou discriminatórias contra grupos sem nenhuma conotação racial, como o dos homossexuais, também possa ser considerada como imprescritível. Não 
logrou surtir efeito a sensata advertência do ministro Moreira Alves: o STF acabou por considerar "o crime de racismo como um tipo de conteúdo aberto, uma vez que os grupos humanos com características culturais próprias são inúmeros".

Fiquemos, porém, com os dois pontos que nos parecem essenciais, no que diz respeito aos objetivos deste trabalho.

O primeiro é que, no emblemático julgamento deste habeas corpus, três ministros do Supremo Tribunal Federal consideraram a pesquisa das intenções do legislador constituinte, objetivamente manifestadas, como dado importante, senão decisivo, para interpretação de uma cláusula da Constituição. E dois outros integrantes do Tribunal, embora chegando a conclusão inteiramente diversa, também abordaram brevemente esse ângulo, confirmando sua relevância.

O segundo aspecto a ressaltar é que a abordagem originalista, caso tivesse aqui prevalecido, teria evitado o perigoso precedente que foi aberto pelo Supremo Tribunal Federal, que acabou por ampliar excessivamente uma séria restrição a direito fundamental. 


\subsection{Perda de mandato por infidelidade partidária}

A questão da perda de mandato por ato de infidelidade partidária, recentemente reintroduzida em nosso direito constitucional em virtude de uma mudança de interpretação do Supremo Tribunal Federal, mostra-se como um tópico fundamental para nossa análise.

Isto porque se trata de um dos mais drásticos exemplos da amplitude que atingiu, em nosso país, o ativismo da jurisdição constitucional: neste caso, o Pretório Excelso não foi além do texto da Constituição, para eventualmente atualizá-la; em verdade, valendo-se de uma argumentação com suporte em princípios gerais, foi em sentido diametralmente oposto ao que deliberado pelo constituinte.

Por outro lado, a questão nos permitirá mostrar a importância da análise originalista como ferramenta para preservar o real conteúdo e significado da Constituição, em estrito respeito à decisão tomada pelos representantes do povo investidos do poder constituinte.

\subsubsection{Pressuposto da análise originalista: o histórico normativo}

Principiando pela conceituação, podemos dizer que a fidelidade partidária constitui a "obrigatória vinculação, do representante, às diretrizes estabelecidas pelos órgãos de direção de seu partido". ${ }^{378} \mathrm{O}$ conceito correlato de disciplina partidária é definido por José Afonso da Silva como o "respeito $e$ acatamento do programa e objetivos do partido, às regras do seu estatuto, cumprimento de seus deveres e probidade no exercício de mandatos ou funções partidárias", além da "aceitação das decisões discutidas e tomadas pela maioria". 379

A infidelidade, portanto, é um acentuado e grave desrespeito a esses deveres, ou o ato mais sério de indisciplina, que se pode manifestar, ainda

\footnotetext{
${ }^{378}$ Walter Costa Porto, Dicionário do Voto, Unb, 200, p. 207.

${ }^{379}$ Curso de Direito Constitucional Positivo, 20ª . ed., 2002, p. 405.
} 
segundo José Afonso da Silva, de duas maneiras: “(a) oposição, por atitude ou pelo voto, a diretrizes legitimamente estabelecidas pelo partido; (b) apoio ostensivo ou disfarçado a candidatos de outra agremiação.",380

A Constituição de 1967 foi a primeira a tratar do tema, determinando, no art. 149, que a lei de regência dos partidos políticos deveria observar o "princípio da disciplina partidária", sem no entanto prever, ela própria, qualquer tipo de sanção. ${ }^{381}$

Tal não pareceu suficiente, porém, aos que desejavam um Congresso Nacional ainda mais “disciplinado". A Junta Militar que assumiu o poder e editou a Emenda n. 1, de 17 de outubro de 1969, incluiu na Carta Política o parágrafo único do art. 152, do seguinte teor:

"Perderá o mandato no Senado Federal, na Câmara dos Deputados, nas Assembléias Legislativas e nas Câmaras Municipais quem, por atitudes ou pelo voto, se opuser às diretrizes legitimamente estabelecidas pelos órgãos de direção partidária ou deixar o partido sob cuja legenda foi eleito. A perda do mandato será decretada pela Justiça Eleitoral, mediante representação do partido, assegurado o direito de ampla defesa".

Esse dispositivo foi substituído pelo $\S 5^{\circ}$, inserido pela Emenda Constitucional n. 11/1978, que suprimiu a possibilidade de ampla defesa, bem como a referência à Justiça Eleitoral para declarar a perda do mandato:

“§ $5^{\circ}$ - Perderá o mandato no senado Federal, na Câmara dos Deputados, nas Assembléias Legislativas e nas Câmaras Municipais quem, por atitude ou pelo voto, se opuser às diretrizes legitimamente estabelecidas pelos órgãos de direção partidária ou deixar o partido sob cuja rege for eleito, salvo se para participar, como fundador, da constituição de novo partido."

\footnotetext{
${ }^{380}$ Curso, cit., p. 405 (o destaque é do original).

${ }^{381}$ Importante notar que no projeto da Constituição, elaborado por uma comissão de juristas, previase que o parlamentar não poderia retirar-se do partido pelo qual eleito, nem transferir-se para outro, exceto se renunciasse ao seu mandato. Mas a proposta foi rejeitada pelo Congresso investido de poderes constituintes (v. Costa Porto, Dicionário do Voto, cit., p. 207; Paulo Bonavides, Ciência Política, Malheiros, 10a. ed., 1997, p. 394).
} 
A regra era também prevista pelo art. 35, inciso $\mathrm{V}$, na redação dada pela Emenda n. 1/69:

Art. 35. Perderá o mandato o deputado ou senador:

$$
\text { (...) }
$$

V - que praticar atos de infidelidade partidária, segundo o previsto no parágrafo único do artigo 152.

Importante aqui salientar que Paulo Bonavides, coerente com sua postura favorável a um mandato partidário e imperativo, distinto da concepção liberal de mandato representativo, afirmou que o rigoroso tratamento do tema pela Emenda Constitucional n. 1/69, com a previsão de perda de mandato para o parlamentar infiel, foi "um passo que reputamos fundamental para a implantação do Estado partidário".382

Opinião contrária era manifestada por Wilson Accioli: embora reconhecendo que sancionar a infidelidade partidária "concorreria para a unidade" e “o fortalecimento da agremiação política”, a medida seria criticável por outro aspecto, pois "essa submissão desfibraria os representantes do partido político, desativandolhes a capacidade criadora ou o espírito crítico". E apontava, a seguir, em conclusão, o aspecto mais relevante da questão: a incompatibilidade dessa rígida disciplina com

\footnotetext{
"a livre deliberação dos legisladores, no exercício pleno de seu mandato representativo (e não imperativo), verberando, criticando, sugerindo, cooperando, construindo. A submissão total pode dar a aparência enganosa de uma concordância tácita, unânime, indiscutível, mas não conduz senão à estagnação e ao quebrantamento das vontades, enquanto a rebeldia aparente, com seus antagonismos, suas dissensões, seus conflitos, gera, com freqüência, a dinamização das idéias e dos projetos (...) promovendo a harmonia entre as diversas correntes do pensamento." 383
}

\footnotetext{
${ }^{382}$ Ciência Política, cit., p. 394.

${ }^{383}$ Instituições de Direito Constitucional, Forense, 1978, pp. 265-266. Os destaques são do original.
} 
As citadas disposições vigoraram até 1985, quando foram excluídas do texto constitucional, já na fase de redemocratização, pela Emenda n. 25/85. A opinião da comunidade jurídica a respeito, naquela época, foi amplamente favorável a essa supressão, o que pode ser exemplificado pelo comentário de Ronaldo Poletti: “A Emenda Constitucional n. 25, de 15 de maio de 1985, suprimiu o polêmico princípio da fidelidade partidária. Fez bem. Fidelidade não se impõe”.

O mesmo autor lembra a origem da fidelidade partidária nos costumes políticos ingleses, que levaram à prática de renúncia do representante que votasse contra a orientação de seu partido, não como resultado de imposição legal, mas por certeza de que esse seria o veredito dos eleitores na próxima eleição. Em tal sistema, "amadurecido na história", a perda do mandato do infiel "promana da consciência cívica, da força do próprio partido e do seu programa". 384

Fazendo uma pequena digressão, diga-se que tal comparação é muito oportuna, inclusive nos dias de hoje, alertando para a inutilidade de soluções artificialmente engendradas, que buscam suprir, por construção jurisprudencial, convicções que somente se firmam após lento desenvolvimento histórico.

Voltando ao momento pré-constituinte, a sociedade brasileira debatia diuturnamente, então, os rumos a serem adotados para o país. O tema da fidelidade partidária era recorrente nessas discussões, e isto pode ser verificado, por exemplo, no Anteprojeto de Constituição elaborado pela "Comissão de Notáveis"385, que propunha a perda de mandato do Senador ou Deputado "que deixar o partido sob cuja legenda foi eleito, salvo para participar como fundador de novo partido" (art. 162, inciso VI), ao mesmo tempo em que previa a edição de lei complementar que, disciplinando a atividade e organização dos partidos políticos, deveria garantir sua “democracia interna" e a "representação de suas diversas correntes".

\footnotetext{
${ }^{384}$ Da Constituição à Constituinte, 1986, p. 70.

${ }^{385}$ Trata-se da Comissão Provisória de Estudos Constitucionais, também conhecida por "Comissão Afonso Arinos", convocada pelo presidente José Sarney, por meio do Decreto n. 91.450, de 18 de julho de 1985.
} 
É sabido que esse anteprojeto, embora não formalmente enviado à Assembléia Constituinte, serviu como uma das principais fontes de seu trabalho ( $v$. José Afonso da Silva, Direito Comparado).

Assim, embora recentemente extinta a perda de mandato por infidelidade partidária, os constituintes lidavam com a proposta de sua reimplantação.

Logo no início dos trabalhos da Assembléia, na 6 ${ }^{\mathrm{a}}$. Reunião da Subcomissão do Sistema Eleitoral e Partidos Políticos, realizada em 29 de abril de 1987, foi discutida a possibilidade de restabelecimento da fidelidade partidária como causa para perda de mandato, formando-se um consenso preliminar em sentido contrário. $^{386}$

O assunto continuou em pauta, e no mês seguinte duas propostas foram apresentadas naquele sentido.

A primeira foi a Sugestão 3.275, do constituinte Adylson Motta, propondo que, no dispositivo que tratasse das condições de elegibilidade, fosse acrescentado parágrafo do seguinte teor: "O detentor de cargo eletivo que deixar o partido pelo qual foi eleito perderá, automaticamente, o mandato, tornando-se inelegível para qualquer outro cargo, no pleito subseqüente."

A sugestão, como se vê, era extremamente drástica, por não admitir nenhuma escusa, por ser automática, e por importar, ainda, na sanção de inelegibilidade para as eleições seguintes. Na justificativa apresentada, declarou o constituinte que agia "inspirado no art. 63, do Projeto da Comissão Afonso Arinos", e seu objetivo era "restabelecer o princípio da fidelidade partidária". 387

Proposta mais moderada foi apresentada pelo constituinte Brandão Monteiro. Tratava-se da a Sugestão n. 4.514, visando incluir o seguinte dispositivo: "Art. Perderá o mandato o deputado ou senador: (....) IV-Que deixar o Partido

\footnotetext{
${ }^{386}$ Vale ressaltar, nesse sentido, a posição do relator da Subcomissão, constituinte Francisco Rossi, e também dos constituintes Jamil Haddad e Hélio Bicudo (este, falando em nome de toda a bancada do Partido dos Trabalhadores) - Assembléia Nacional Constituinte - Atas das Comissões, pp. 36-37 texto disponível no endereço eletrônico www.senado.gov.br/publicacoes, "Anais do Senado Federal". ${ }^{387}$ Diário da Assembléia Nacional Constituinte (Suplemento), 14.5.1987, p. 118.
} 
sob cuja legenda for eleito, salvo para participar como fundador de novo Partido Político.”

Na justificativa dessa propositura, assinalou o seu autor:

"É imprescindível na democracia que os partidos políticos sejam fortes e os deputados e senadores eleitos por qualquer partido político não o utilizem como mero trampolim ou de acordo com suas conveniências eventuais.

Com a presente sugestão, buscamos resguardar a fidelidade partidária (....) com o objetivo de fixar o Mandato popular como consequência da atividade partidária e compromissada com os programas políticos, utilizados no período eleitoral.

Exclui-se, somente, a hipótese de qualquer Parlamentar abandonar a legenda para a qual foi eleito, quando for para fundar nova agremiação político-partidária."

Ainda no mês de maio de 1987, o constituinte Nilson Gibson apresentou à Comissão da Organização Eleitoral, Partidária e Garantia das Instituições a Emenda n. 400121-4, que estendia a regra expressamente aos legislativos estaduais e municipais:

"Perderá o mandato no Senado Federal, na Câmara dos Deputados, nas Assembléias Legislativas e nas Câmaras Municipais o portador do mandato que, por atitude ou por voto, se opuser às diretrizes legitimamente estabelecidas pelos órgãos de direção partidária, ou deixar o Partido sob cuja legenda foi eleito, salvo se para participar, como fundador, da constituição de novo Partido".

A proposta completava-se com a atribuição de competência à Justiça Eleitoral para declarar a perda do mandato, assegurada ampla defesa, e com a explicitação do que seriam "diretrizes legitimamente estabelecidas". 389

\footnotetext{
${ }^{388}$ Diário da Assembléia Nacional Constituinte (Suplemento), ed. 16.5.1987, pp. 175-176.
} 
Nas Atas da Comissão de Sistematização, encontramos o registro da reunião de 20 de outubro de 1987, em que o destaque n. 2286, que propunha a perda do mandato para "o ocupante de cargo eletivo que abandonar ou for expulso do partido pelo qual foi eleito", foi retirado pelo seu próprio autor, em razão de consenso que se formara na Comissão. ${ }^{390}$ Aprovou-se, assim, que a disciplina da fidelidade partidária deveria constar necessariamente dos estatutos partidários, sem no entanto ensejar a perda de mandato. E tal decisão foi mantida até o final.

Portanto, foi muito clara a deliberação dos constituintes: prestigiaram o princípio da fidelidade partidária e conferiram-lhe dignidade constitucional, mas como valor a ser observado na vida interna dos partidos, circunscrevendo a esse âmbito as sanções eventualmente cabíveis.

Sobreleva notar que, após a constituinte, houve novas tentativas de incluir a infidelidade partidária como causa de perda de mandato.

Na Revisão Constitucional de 1993-1994, nada menos do que vinte e sete propostas de emenda nesse sentido foram apresentadas, ora alterando o art. $55^{391}$, ora os arts. $14^{392}$ ou $17^{393}$, ou ainda em combinações desses dispositivos. ${ }^{394} \mathrm{O}$ assunto continuou em pauta nos anos seguintes. ${ }^{395}$. O reiterado insucesso dessas

${ }^{389}$ Relatório também disponível no endereço eletrônico do Senado Federal, anteriormente citado.

390 Atas da Comissão de Sistematização, Suplemento "C" dos Diários da Assembléia Nacional Constituinte, p. 1449.

${ }^{391}$ Por exemplo, as emendas ns. 004456-2 e 000042-6, do deputado Adylson Motta; n. 000050-3, do deputado Geraldo Alckmin;

${ }^{392}$ Assim previsto pelas emendas n. 008927-5, do deputado Reinhold Stephanes, e n. 008367-1, do deputado Sérgio Spada.

${ }^{393}$ Por exemplo, as emendas n. 001050-0, do senador Gilberto Miranda, e n. 000178, do deputado José Luiz Clerot.

${ }^{394}$ Foi o caso das emendas n. 016646-9, do deputado José Serra, e n. 009739-2, do deputado Pinheiro Landim (fonte: levantamento do Centro de Documentação e Informação da Câmara dos Deputados).

${ }^{395}$ Marcelo Lamy registra que "mais de quinze propostas de emenda constitucional já foram apresentadas nesse sentido", apontando como exemplos as PECs 90/95, 166/95, 283/95, 41/96, 44/98, 51/2005, cada qual com importantes diferenças, tais como: a possibilidade de troca de partido após um certo período (metade, ou dois terços) do mandato; a eventual aplicação ao chefe do Poder Executivo; a atribuição de competência para declarar a perda do mandato (se da Justiça Eleitoral ou do próprio partido), ou ainda a possível inelegibilidade do parlamentar infiel (Reflexões sobre a 
tentativas demonstra que a decisão do constituinte originário vem sendo mantida pelo constituinte derivado, único democraticamente legitimado para tal modificação.

\subsection{2 - Posição da doutrina até 2007}

A doutrina, de forma geral, não teve dificuldade em interpretar o novo texto constitucional, em vista de sua clareza.

Escrevendo antes da nova Constituição, em 1987, Manoel Gonçalves Ferreira Filho criticava a liberdade irrestrita de mudança de partido, então vigente, manifestando-se favoravelmente à previsão de perda de mandato por infidelidade partidária, que considerava necessária para a obtenção de "um mínimo de coerência partidária". ${ }^{396}$ Mesmo sendo esta sua posição pessoal, reconheceu que outra foi a orientação adotada pela Carta de 1988: nesta, a infidelidade partidária implicava sanções a serem previstas nos estatutos dos partidos, dentre as quais não poderia ser incluída a perda do mandato, cabível apenas nos casos previstos no art. 55 da Constituição. $^{397}$

José Afonso da Silva também é enfático:

"Os estatutos dos partidos estão autorizados a estatuírem sanções para os atos de indisciplina e infidelidade partidária, que poderão ir da simples advertência até à exclusão. Mas a Constituição não permite a perda do mandato por infidelidade partidária. Ao contrário, até o veda, quando, no art. 15, declara vedada a cassação de

Fidelidade Partidária, Escola Superior de Direito Constitucional, 2007 - texto disponível em www.esdc.com.br).

${ }^{396}$ O Anteprojeto dos Notáveis, p. 36.

${ }^{397}$ Curso de Direito Constitucional, Saraiva, $31^{\text {a }}$. ed., 2005, p. 180. A lição é reiterada pelo mesmo autor em seus Comentários à Constituição Brasileira de 1988, tomo I, Saraiva, 1990, p. 137. 
direitos políticos, só admitidas a perda e a suspensão deles nos estritos casos indicados no mesmo artigo". 398

Celso Ribeiro Bastos, reconhecendo que a fidelidade partidária fora prevista na atual Constituição de forma mais amena do que na Carta anterior, elogia a moderação do constituinte de 1988. Embora a "profunda indisciplina partidária reinante no Brasil" fosse um mal a combater, era preciso admitir que o vínculo do eleitor com o candidato por ele escolhido era muito mais direto, sendo praticamente desconhecidos os programas partidários. Nesse contexto, a exacerbação das regras de fidelidade poderia trazer "a séria ameaça de uma ditadura interna no partido", além de significar "um desrespeito para com a própria vontade popular", mais facilmente captável pelo parlamentar, e não por programas ou agremiações partidárias. Conclui o saudoso professor com advertência semelhante à de Ronaldo Poletti:

"As sanções definitivas [aos parlamentares infiéis] devem ser de ordem política. Aqueles que se desgarram dos programas partidários, traindo a vontade dos que o elegeram, numa democracia operativa e eficaz, deverão merecer o mais completo repúdio nas eleições seguintes.

Jamais institutos técnico-jurídicos poderão se substituir plenamente à força sancionadora do eleitorado que é, ainda, o mais legítimo."399.

Alexandre de Moraes assinalava que "no atual ordenamento constitucional a mudança de partido não acarreta a perda do mandato de deputado (CF, art. 55), e, igualmente, não poderia acarretar a perda de suplência". ${ }^{400}$

\footnotetext{
${ }^{398}$ Curso de Direito Constitucional Positivo, 5a . ed., 1990 (a primeira após a nova Constituição), p. 349.

399 Comentários à Constituição Brasileira (obra escrita em parceria com Ives Gandra da Silva Martins), vol. 2, 1989, pp. 613-615. Tais comentários foram integralmente reproduzidos por Celso Bastos em seu Curso de Direito Constitucional, 18 a ed., 1997, pp.278-279.
} 
Monica Caggiano, embora criticando severamente a opção do constituinte, que acabou ensejando o "turismo interpartidário" e a "dança das cadeiras" $" 401$ no parlamento, reconhece que "o modelo acolhido pelo atual Estatuto Fundamental, todavia, não autoriza laços sensíveis entre o leito e o partido sob cuja legenda concorreu”, prevendo o trato da infidelidade partidária apenas em âmbito estatutário, "de cogência duvidosa”. Salienta essa autora, reconhecida especialista na matéria, que "ao outorgar ao parlamentar a missão de representar o povo, o constituinte o liberou da ligadura com o partido, abrindo a brecha para a continuidade do esquema de turismo interpartidário, que retira todo o equilíbrio ao quadro de partidos e ao sistema que ele mesmo pretendia engendrar.. 402

Para Uadi Lammêgo Bulos também era fora de dúvida que “...embora a fidelidade partidária seja um vetor reconhecido pela Carta Suprema, ninguém perde o mandato por ser infiel aos objetivos dos partidos políticos. ${ }^{403}$

Vários outros renomados constitucionalistas expressaram-se com a mesma ênfase e segurança:

"Os atos de infidelidade partidária podem redundar até na exclusão do 'infrator' do partido. Para tanto, haverá de constar a hipótese do próprio estatuto partidário em questão. Isso significa,

${ }^{400}$ Direito Constitucional, $18^{\mathrm{a}}$. ed., 2005, p. 381.

${ }^{401}$ A expressão é também utilizada por Augusto Aras, para quem "o descalabro da mudança de partido chegou ao cúmulo, nas eleições estaduais e federal de 2002, quando, entre a data da diplomação e antes mesmo da posse, em $1^{\circ}$ de janeiro de 2003, dezenas de parlamentares migraram, impunemente, chocando a sociedade brasileira com a já famosa dança das cadeiras, cujo objetivo foi o aumento de tempo na propaganda eleitoral no certame de 2004, sem embargo da satisfação de interesses pessoais" (Fidelidade Partidária: A Perda do Mandato Parlamentar, 2006, p. 250). Carlos Ranulfo Melo registra que, entre 1985 e 2001, nada menos do que 852 deputados federais mudaram de partido, sendo que quase duas centenas deles fizeram-no mais de uma vez, totalizando 1041 trocas de legenda nesse período (Retirando as cadeiras do lugar: migração partidária na Câmara dos Deputados (1985-2002), UFMG, 2004, p. 152). O ministro Ricardo Lewandowski também expressou sua preocupação com o fenômeno, no voto que proferiu nos mandados de segurança 26.602, 26.603 e 26.604, a seguir referidos; não obstante, isso não foi motivo para que ele se afastasse do texto e do espírito da Constituição, pois votou contrariamente à perda de mandato na hipótese de troca de legenda.

${ }^{402}$ Direito Parlamentar e Direito Eleitoral, 2004, pp. 112-114.

${ }^{403}$ Uadi Lammêgo Bulos, Curso de Direito Constitucional, $1^{\text {a }}$. ed. , 2007, p. 710. O mesmo autor, na $4^{\mathrm{a}}$. edição de sua Constituição Federal Anotada, Saraiva, 2002, p. 461, já afirmava: "Cumpre recordar que a Constituição de 1988 não permite a perda de mandato por infidelidade partidária" (o destaque é nosso). 
portanto, que as conseqüências só poderão ser de âmbito interno (daí poder falar em liberdade partidária como circunscrita a esse âmbito). Como consequência, no caso de infidelidade ou indisciplina partidária de candidato já eleito, não haverá a perda do respectivo mandato. Aliás, para tanto, a hipótese haveria de constar do rol indicado no art. 15 da C.F." ${ }^{404}$;

"Ao contrário, então, da Constituição anterior, a nova não prevê a possibilidade de perda do mandato em função de infidelidade partidária. Segundo José Afonso da Silva, além de não admitir a perda do mandato em face da infidelidade partidária, a Constituição vai mais longe, estabelecendo vedação nesse sentido. Deveras, no art. 15, a Lei Fundamental 'declara vedada a cassação de direitos políticos, só admitidas a perda e a suspensão deles nos estritos casos indicados no mesmo artigo'. Já a Constituição anterior (Emenda Constitucional 1/69) não só exigia que os partidos reclamassem disciplina de seus membros como previa a perda do mandato do parlamentar que deixasse o partido pelo qual fora eleito ou descumprisse as diretrizes legitimamente estabelecidas pela direção partidária. A matéria era regulada pela Lei 5.682/71. A Emenda Constitucional 25, de 15/05/85, suprimiu o instituto, agora revigorado, em outras bases, pela Constituição de 1988,"405;

"uma vez que o estatuto partidário, embora possa e deva cuidar da disciplina e fidelidade, não pode ir além da fixação e aplicação, ao transgressor, da pena de exclusão do quadro. O mandato eletivo do infrator é, contudo, intangível, uma vez que as hipóteses de perda são exaustivamente fixadas pelo art. 55 da Carta Federal, não existindo previsão de sanção de tal ordem, aplicável por conta de indisciplina ou infidelidade partidária"; 406

\footnotetext{
${ }^{404}$ André Ramos Tavares, Curso de Direito Constitucional, Saraiva, 5a . ed., 2007 , p. 733. ${ }^{405}$ Clémerson Merlin Clève, Fidelidade Partidária, Curitiba, Juruá, 1999, pp. 23-25.

${ }^{406}$ Luis Carlos Hiroki Muta, Direito Constitucional, t. I, 2007, pp.204-205 (destaques nossos).
} 
“Ao partido, e a mais ninguém, compete aplicar sanção por quebra de fidelidade partidária. Se essa sanção, ou a troca de legenda, acarreta a perda de mandato (de lege ferenda, possível apenas com alteração constitucional), é matéria a ser sopesada criteriosamente: impossível admiti-las sem respeito ao legítimo direito de divergência",407;

"Examinada a Constituição de 1988, tem-se que o ato de infidelidade ou de indisciplina partidárias não deve, jamais, redundar em perda de mandato parlamentar, posto que as hipóteses de perda estão taxativamente previstas nos incisos do art. 55, da Constituição". ${ }^{408}$

Em dissertação de mestrado sobre o tema, publicada em 2005, Auro Augusto Caliman também foi categórico:

"Muito embora não haja candidatura extrapartidária no Brasil, o abandono do partido pelo qual originariamente foi eleito não subtrai do titular de mandato eletivo o status que a eleição e o diploma da Justiça Eleitoral lhe garantem. Da mesma forma, decidiu o Supremo Tribunal Federal que não se subtrai a condição de suplente daquele que se desvincula do partido pelo qual tenha sido eleito, garantindo-se-lhe o direito à expectativa de ser convocado para exercer o mandato (...)". 409

Enfim, ressalvadas pouquíssimas vozes discordantes - dentre as quais podemos destacar Vânia Siciliano Aieta ${ }^{410}$, Augusto Aras ${ }^{411}$ e Palhares Moreira

\footnotetext{
${ }^{407}$ Sérgio Sérvulo da Cunha, Reforma Eleitoral Partidária (Revista de Informação Legislativa, n. 125, 1995, p. 11 - os destaques são nossos).

${ }^{408}$ Manoel Jorge e Silva Neto, Curso de Direito Constitucional, 2006, p. 581.

${ }^{409}$ Auro Augusto Caliman, Mandato Parlamentar: aquisição e perda antecipada; ed. Atlas, 2005, p. 195.

${ }^{410}$ É sumamente interessante observar em que bases esta autora constrói sua teoria, revelando uma concepção centralista e hierarquizada da organização dos partidos: "Por ser um adepto ativo, o militante costuma sedimentar a sua ação política em algum diretório, no movimento ou núcleo de
} 
Reis ${ }^{412}$ - havia grande consenso na doutrina a respeito desse ponto: a Constituição de 1988 não autoriza a perda de mandato por infidelidade partidária ${ }^{413}$.

\title{
5.7.3 A jurisprudência do STF e do TSE de 1988 a 2007
}

\author{
Logo no início da vigência da nova Constituição o Tribunal
}

Superior Eleitoral, em resposta à Consulta n. 9.914, editou por unanimidade a Resolução n. 15.090, de 2 de março de 1989, em que o relator, ministro Francisco Rezek, reconhecia ser

base do partido. Ao militante impõe-se, necessariamente, a fidelidade partidária. Se distinguem dos dirigentes na medida em que não exercem funções de chefia. Na realidade, perfazem-se como executantes da empreitada política, pois, sem eles, não haveria a concretização da ação política do partido. (...) Toda organização partidária requer um determinado número de pessoas que the dediquem a completude de suas atividades. Com isso, os militantes são obrigados a delegar aos dirigentes a missão de controlar o partido. O acatamento da militância às diretrizes impostas, pelos dirigentes implica, necessariamente, a postura ética dos dirigentes em manifestarem atitudes que demonstrem fidelidade política com a vontade da massa partidária. Tal comportamento configurase como um fato gerador de fidelidade partidária, pois seria contraditório exigir fidelidade dos militantes e, consequentemente, dos representantes eleitos pelo partido se, ao revés, os dirigentes apresentarem um comportamento político autoritário, desconectado com as exigibilidades da necessária e salutar democracia interna. (...) A necessidade da massa em ter um chefe tem suas razões. $\mathrm{Na}$ vida dos partidos constata-se que apenas uma minoria participa do processo de tomada de decisão. Dá-se uma renúncia voluntária da condição de partícipe do processo decisório (...) A necessidade de veneração configura-se como um outro fator. A adoração dos militantes por seus chefes e dirigentes permanece latente. (...) o mandato perfaz-se como uma construção coletiva de interesses e não simplesmente como uma iniciativa individual". É a partir dessas premissas - que evidentemente não guardam a mais remota relação com o texto da Constituição - que a autora acaba por admitir que sua tese é, simplesmente, a defesa de uma opção política, embora insista em afirmá-la como resultado do exercício de suposta interpretação : “..... por Hermenêutica Constitucional, já se poderia, nesse momento, possibilitar a perda do mandato eletivo, em uma perspectiva de interpretação sistêmica. Assim, irá se sustentar que o intérprete da norma constitucional, entre várias alternativas jurídicas de concretização exegética, opta politicamente por uma determinada tese, configurando-se uma questão de decidibilidade política e não de verdade jurídica" (Vânia Siciliano Aieta, Partidos Politicos, Lumen Juris, 2006, pp. 293, 298299, 304, 310; os destaques seguem exatamente o texto original).

${ }^{411}$ Fidelidade partidária: A Perda do Mandato Parlamentar; Lumen Juris, 2006.

${ }^{412}$ O partido político e a lei de 1995, In: Cármen L. Antunes Rocha e Carlos M. Velloso, Direito Eleitoral, Del Rey, 1996, p. 188.

${ }^{413}$ Além dos já citados, também se manifestaram nesse sentido, entre outros: Kildare Gonçalves Carvalho, Direito Constitucional, 2006, p. 776; Orides Mezzaroba, Introdução ao Direito Partidário Brasileiro, 2a . ed., 2004, pp. 276-279; Marcelo Lamy, Reflexões sobre a fidelidade partidária, 2007; Walber de Moura Agra, Curso de Direito Constitucional, Forense, 2006, p. 233; Rui Stoco e Leandro de O. Stoco, Legislação Eleitoral Interpretada, RT, 2a. ed., p. 141; 
"Inexistente no nosso ordenamento jurídico a perda de mandato parlamentar por infidelidade partidária, desde a vigência da Emenda Constitucional n. 25/85", muito embora a Constituição Federal assegure aos partidos políticos o estabelecimento de normas de fidelidade e disciplina partidárias em seus estatutos - art. $17-\S 1^{\circ}$., impõe-se resposta afirmativa à presente consulta, como opina o parecer ministerial". 414

Poucos dias depois essa orientação foi mantida em relação à Consulta n. 9.948, de seguinte teor: "Vereador eleito por uma determinada legenda partidária, ao ingressar em outro Partido, conserva íntegro o mandato para o qual foi eleito?”. A resposta, positiva, veio com a Resolução n. 15.135, de 21 de março de 1989 (desta feita foi relator o ministro Roberto Rosas), reafirmando o Tribunal, novamente por unanimidade, não perder o mandato "o filiado que, detentor de cargo eletivo, deixa o partido sob cuja legenda foi eleito a fim de transferir-se para outro".

Acompanhando a posição do Tribunal Superior Eleitoral, bem como a doutrina amplamente majoritária, o Supremo Tribunal Federal também proclamou com ênfase que a atual Constituição não admitia a perda de mandato por ato de infidelidade partidária.

Quando a nova Carta contava um ano de vigência, o Supremo Tribunal julgou, na mesma sessão (de 11.10.1989), os mandados de segurança ns. 20.927-5 e 20.916-0; no primeiro foi relator o ministro Moreira Alves, que em seu voto deu especial relevo ao histórico normativo da fidelidade partidária:

"Em face da Emenda n. 1/69, que, em seu artigo 152, parágrafo único (que, com alteração de redação, passou a parágrafo $5^{\circ}$ desse mesmo dispositivo por força da Emenda Constitucional n. 11/78, estabelecia o princípio da fidelidade

\footnotetext{
${ }^{414}$ O parecer, oferecido pelo Vice-Procurador Geral Eleitoral Ruy Ribeiro Franca, com a aprovação do Procurador Geral Sepúlveda Pertence (presente à sessão de julgamento), assinalava "não decorrerem quaisquer prejuízos, muito menos perda de mandato, para o filiado que, detentor de cargo eletivo, deixa o Partido sob cuja legenda foi eleito a fim de transferir-se para outro". Acompanharam o voto do relator os ministros Aldir Passarinho, Sydney Sanches, Bueno de Souza, Miguel Ferrante, Roberto Rosas e Vilas Boas (texto disponível no endereço eletrônico www.tse.gov.br).
} 
partidária, Deputado que deixasse o Partido sob cuja legenda fora eleito perdia o seu mandato. (...)

Com a Emenda Constitucional n. 25/85, deixou de existir esse princípio de fidelidade partidária, e, em razão disso, a mudança de Partido por parte de Deputado não persistiu como causa de perda de mandato, revogado o inciso $\mathrm{V}$ do art. 35 que enumerava os casos de perda de mandato.

$\mathrm{Na}$ atual Constituição, também não se adota o princípio da fidelidade partidária, o que tem permitido a mudança de Partido por parte de Deputados sem qualquer sanção jurídica, e, portanto, sem perda de mandato.

Ora, se a própria Constituição não estabelece a perda de mandato para o Deputado que, eleito pelo sistema de representação proporcional, muda de Partido e, com isso, diminui a representação parlamentar do Partido por que se elegeu (e se elegeu muitas vezes graças aos votos de legenda), quer isso dizer que, apesar de a Carta Magna dar acentuado valor à representação partidária (artigos $5^{\circ}, \mathrm{LXX},{ }^{\prime} \mathrm{a}^{\prime} ; 58, \S 1^{\circ} ; 58, \S 4^{\circ} ; 103$, VIII), não quis preservá-la com a adoção da sanção jurídica da perda do mandato, para impedir a redução da representação de um Partido no Parlamento. Se o quisesse, bastaria ter colocado essa hipótese entre as causas de perda de mandato, a que alude o art. 55." ${ }^{415}$

Nesse mesmo julgamento, o não menos eminente ministro Sepúlveda Pertence foi igualmente enfático:

"Continuo a pensar, Senhor Presidente, cada vez que vejo a dedução das razões da posição oposta, mais me convenço de que se funda ela na idealização e no transplante, para o nosso regime positivo de representação proporcional, de uma ortodoxia do sistema, pensada em termos abstratos, que a nossa Constituição não conhece. (...)

${ }^{415}$ Texto disponível em www.stf.jus.br. Os destaques são nossos. 
No entanto, na minha convicção restou inabalada, com todas as vênias, a premissa de que parti: a falta, em nosso direito constitucional vigente, de base para decretar a perda de mandato de titular, convicção que agora caba de receber valiosos subsídios do eminente Ministro Moreira Alves.” (os destaques são nossos).

Traz a seguir, o mesmo eminente ministro, um precioso argumento: quando se tratou de enumerar as causas de perda de mandato, a Constituição não fugiu nem mesmo da redundância, em ordem a atender, em primeiro lugar, à clareza, indispensável quando se cuida da restrição a um direito fundamental:

A partir do sistema, inferir-se essa perda não me parece definitivamente autorizado pelo texto constitucional, que é - e nem poderia ser de modo diverso, tal a gravidade da sanção exaustivo, no art. 55, a ponto de tornar explícito, por exemplo, o que seria muito mais fácil de extrair por inferências lógicas: que o Deputado que perde os direitos políticos perderá seu mandato eletivo."

Ainda no mesmo julgamento, os votos dos ministros Francisco Rezek e Aldir Passarinho prestigiaram os argumentos de natureza histórica que aqui estamos a defender, interpretando a Constituição segundo o contexto em que foi ela promulgada, exatamente porque esse contexto é que permite aferir, sem nenhuma dúvida, a intenção dos constituintes.

Disse o ministro Rezek:

“ A Constituição de 1988 tem naturalmente um subsolo. Este consiste, basicamente, nas suas circunstâncias, no seu momento histórico. Não foi por acaso que o constituinte de 88 se omitiu de prescrever, com a riqueza vernacular quantitativa que usou em tantos temas menores, sobre a fidelidade partidária. Não quis fazê-lo por acreditar, provavelmente, que não saímos ainda daquela zona cinzenta em que nos encontramos desde os acontecimentos de 64, ou, mais precisamente, desde quando dissolvidos os antigos partidos (...) Isso é uma realidade que o constituinte deve ter querido prestigiar, e ao direito positivo me atenho". 
E o ministro Aldir Passarinho, em trecho que também adota o argumento de cunho originalista:

"Quer dizer que não houve, a meu ver, omissão na Constituição em não estabelecer o pincípio de perda de mandato por infidelidade partidária, pois o tema sempre esteve presente. E tanto é certo que na Constituição anterior, que não podia ser naturalmente esquecida dos novos constituintes, havia regra expressa nesse sentido, a qual foi, como se disse, ameniada pela Emenda Constitucional n. 11 (..)

$\mathrm{Na}$ verdade, o que a Constituição prevê é que é condição de elegibilidade haver a filiação a partido político. Realmente, essa é a exigência que a Constituição faz.

No tocante à infidelidade partidária, bem como no pertinente à indisciplina, a Constituição expressamente remeteu a fixação das normas referentes a tais pontos aos Estatutos dos Partidos Políticos (...)

Mas, nem aí, a Constituição estabelece que, como norma de fidelidade partidária, possa ser determinada a perda do mandato político. Isso não está implícito na Constituição (....)

(...) não se encontra na Constituição Federal, nem na legislação pertinente, nada, absolutamente nada, que implique na perda do mandato do deputado ou do senador como, também, a perda de suplência, no caso de mudança de partido (...)”.

No MS 90.216-0, também julgado em 11.10.1989, tratou-se da questão da troca de partido não pelo parlamentar, mas pelo suplente, sendo reafirmada a tese da inexistência de sanção constitucional ou legal para a migração de partido (foi relator para o acórdão o ministro Sepúlveda Pertence).

Quinze anos depois, mesmo com uma composição bastante modificada, o Supremo reafirmava o mesmo entendimento ao julgar o Mandado de Segurança n. 23.405-9, cuja ementa consigna: 
"Mandado de Segurança. 2. Eleitoral. Possibilidade de perda de mandato parlamentar. 3. Princípio da fidelidade partidária. Inaplicabilidade. Hipótese não colocada entre as causas de perda de mandato a que alude o art. 55 da Constituição. 4. Controvérsia que se refere a Legislatura encerrada. Perda de objeto. 5. Mandado de Segurança julgado prejudicado".

E mesmo estando prejudicado o pedido, o relator deste caso, ministro Gilmar Mendes, fez constar de seu voto:

"Embora a troca de partidos por parlamentares eleitos sob o regime da proporcionalidade revele-se extremamente negativa para o desenvolvimento e continuidade do sistema eleitoral e do próprio sistema democrático, é certo que a Constituição não fornece elementos para que se provoque o resultado pretendido pelo requerente". 416

Desnecessário dizer que toda a legislação eleitoral, bem como as resoluções do TSE, ao longo desses anos, seguiram a linha adotada pelo Pretório Excelso.

\subsubsection{A alteração da Constituição pela via jurisprudencial}

Radical mudança de orientação iniciou-se em 27 de março de 2007. Nessa data, em resposta à Consulta 1.398, formulada pelo Partido da Frente Liberal (hoje denominado Democratas) ${ }^{417}$, o Tribunal Superior Eleitoral, por ampla maioria, editou a Resolução n. 22.526, estatuindo que “os Partidos Políticos e as coligações conservam direito à vaga obtida pelo sistema eleitoral proporcional, quando houver pedido de cancelamento de filiação ou de transferência do candidato

\footnotetext{
${ }^{416}$ Pleno, j. 22.3.2004, votação unânime. Acompanharam o relator os ministros Maurício Corrêa (presidente), Marco Aurélio, Ellen Gracie, Cezar Peluso, Carlos Britto e Joaquim Barbosa.

${ }^{417}$ Já na consulta evitava-se o uso da expressão "perda de mandato", como naquelas respondidas em 1989. Desta feita, formulava-se a seguinte indagação: "Os partidos e coligações têm o direito de preservar a vaga obtida pelo sistema eleitoral proporcional, quando houver pedido de cancelamento de filiação ou de transferência do candidato eleito por um partido para outra legenda?"
} 
eleito por um partido para outra legenda"418.

Com base nessa Resolução, três partidos políticos (PSDB, PPS e DEM) impetraram mandados de segurança contra o presidente da Câmara dos Deputados, perante o Supremo Tribunal Federal, pleiteando a declaração de vacância dos cargos de Deputados Federais que haviam trocado de legenda (MS. 26.602, relator o ministro Eros Grau; MS ns. 26.602, relator o ministro Celso de Mello; MS 26.604, relatora a ministra Cármen Lúcia) ${ }^{419}$.

Nesses mandados de segurança, por ampla maioria (oito votos contra três), o Supremo ratificou a posição adotada pelo Tribunal Superior Eleitoral, buscando suprir a ausência de norma expressa pela invocação de princípios e idéias tidas como implícitas: a Constituição não admite candidatura avulsa (uma vez que a filiação partidária é condição de elegibilidade - CF, art.14, $\S 3^{\circ}$, inc. V) e adota o sistema proporcional, em que as vagas no parlamento são atribuídas aos partidos ou coligações $^{420}$, não aos candidatos individualmente; o eleitor pode votar somente num partido, abstendo-se de indicar um candidato específico; o sistema eleitoral está "fundado na idéia da representação de opiniões, ideologias e visões políticas" isso que a fidelidade é devida ao povo, e não propriamente aos $\operatorname{partidos}^{422}$; no entanto, as opções políticas e candidaturas são viabilizadas necessariamente por meio dos partidos políticos, aos quais pertence o mandato; o ato de desfiliação do eleito não seria causa de perda de mandato, propriamente, mas equivaleria a uma renúncia tácita, conferindo ao partido o direito de reivindicar a vaga, para que um suplente possa assumi-la.

\footnotetext{
${ }^{418}$ Diário da Justiça da União, 9.5.2007, p. 143 (texto também disponível em www.tse.gov.br).

${ }^{419} \mathrm{Na}$ ocasião foi impetrado um quarto mandado de segurança, de n,. 26.890, com o mesmo objetivo, mas o impetrante, Partido Popular Socialista, desistiu da impetração.

${ }^{420}$ No caso de perda de mandato do parlamentar eleito por uma coligação, a quem caberá indicar o suplente - ao partido ou à coligação? Em decisão liminar no Mandado de Segurança 29.988, tratando de tal hipótese, o Plenário do STF, por cinco votos contra três, conferiu precedência ao partido (decisão de 9.12.2010, relator o min. Gilmar Mendes - v. Informativo STF 612). Todavia, a eleição por sistema proporcional - um dos principais argumentos utilizados para justificar a mudança de orientação do Supremo

- leva em conta os votos da coligação, não do partido. A dúvida quanto a esse ponto tem ensejado sérios problemas, pois a Câmara sempre deu posse aos suplentes das listas apresentadas pelas coligações (nesse sentido: Decisão do Supremo gera confusão sobre quem deve assumir - O Estado de S. Paulo, ed. eletrônica, 25.12.2010).

${ }^{421}$ Palavras proferidas em intervenção do ministro Cezar Peluso, no julgamento da Consulta n. 1.398.

${ }^{422}$ Argumento que constou dos votos dos ministros José Delgado, no TSE (Consulta 1.398), e Celso de Mello, no STF (MS 26.602).
} 


\subsubsection{Posição da doutrina após a mudança jurisprudencial}

A nova posição do STF e do TSE, inovando a ordem constitucional, recebeu reações diversas da doutrina.

Manoel Gonçalves Ferreira Filho limita-se a registrá-la, sem se manifestar quanto ao mérito, afirmando que a perda de mandato em razão de infidelidade partidária foi "deduzida do texto constitucional pelo Tribunal Superior Eleitoral” em razão do monopólico de candidaturas pelos partidos políticos e, no caso dos parlamentares, também em virtude do sistema eleitoral proporcional, com base nos votos dados à legenda. ${ }^{423}$

Alexandre de Moraes também segue a mesma linha, apontando que "o Tribunal Superior Eleitoral reconheceu que os mandatos pertencem aos Partidos Políticos"; estes, em razão disso, têm o direito de "preservá-los se ocorrer cancelamento da filiação partidária ou transferência de legenda". ${ }^{424}$

André Ramos Tavares, na mais recente edição de seu Curso, manteve o texto anteriormente transcrito, ao qual acrescentou que, para ensejar a perda do mandato, a infidelidade "mais especificamente, haveria de estar relacionada no art. 55, que elenca as hipóteses nas quais o parlamentar poderá perder seu mandato", conforme precedentes do STF. No entanto, a despeito da ressalva, esse autor saúda como "altamente moralizadora" e de "sólidos fundamentos constitucionais" a nova posição das Cortes Superiores, concluindo que "o STF cumpriu, aqui, seu papel de impedir as fraudes à Constituição" . ${ }^{425}$

José Jairo Gomes, do mesmo modo, faz grandes elogios à mudança de entendimento, que também considera "moralizadora"

Walber de Moura Agra passou a admitir que "mesmo não havendo norma explicitamente prevendo a fidelidade partidária na Constituição, essa

\footnotetext{
${ }^{423}$ Curso de Direito Constitucional, 36 a . ed., 2010, p. 156.

${ }^{424}$ Direito Constitucional, 24 . ed., 2009, p. 265.

${ }^{425}$ Curso de Direito Constitucional, $8^{\text {a }}$. ed., Saraiva, ..... pp. 821-823.

${ }^{426}$ José Jairo Gomes, Direito Eleitoral, 4ª . ed., 2010, pp. 84-85.
} 
obrigação pode ser construída por interpretação sistêmica, em que vários princípios correlatos e outros implicitos lhe conferem suporte”. ${ }^{427}$

Uadi Lammêgo Bulos, por sua vez, aderiu entusiasticamente à nova posição, agora sustentando que a Constituição - diferentemente do que antes lhe parecia - contém implicitamente a autorização para que o parlamentar infiel seja punido com a perda do mandato:

“A Carta de 1988 não previu, ipsis literis, a hipótese da perda de mandato eletivo.

$\mathrm{Na}$ realidade, não precisa o Texto Maior enunciar, por escrito, o natural dever de fidelidade do parlamentar para com a agremiação política da qual participa.

A obrigação de lealdade extrai-se do princípio da democracia representativa, consagrado em nosso sistema de Direito Positivo (CF, art. $1^{\circ}$., parágrafo único).

Daí o acerto da tese da perda do mandato eletivo por infidelidade partidária, preconizada pelo Supremo Tribunal Federal e é pelo Tribunal Superior Eleitoral, os quais, vivificando a Carta de Outubro, num autêntico exercício de construção constitucional, sacou das entrelinhas constitucionais a referida hipótese...". ${ }^{428}$

Essas "entrelinhas constitucionais" - nos vêm à lembrança as célebres "emanações de penumbras", mencionadas pelo Juiz William Douglas no caso Griswold - estavam tão microscopicamente disfarçadas que passaram despercebidas à esmagadora maioria dos doutrinadores, durante os dezenove anos em que o Supremo Tribunal Federal e o Tribunal Superior Eleitoral tampouco conseguiram vislumbrá-las.

${ }^{427}$ Curso de Direito Constitucional, $4{ }^{\mathrm{a}}$. ed., Gen/Forense, 2008, p. 288.

${ }^{428}$ Curso de Direito Constitucional, 5a . ed., 2010, p. 878. Os destaques são do texto original. Compare-se com a citação da primeira edição, no início deste item. 
Há ainda quem silencie sobre a mudança, mantendo sem qualquer alteração os comentários anteriores; é o caso de José Afonso da Silva ${ }^{429}$ e Manoel Jorge da Silva Neto. ${ }^{430}$

Mas há também autores que mantêm expressamente o anterior ponto de vista. É o caso de Rui Stoco e Leandro de Oliveira Stoco, que após registrar a nova orientação jurisprudencial, reafirmam que "a desfiliação partidária não é contemplada entre as causas de perda de mandato contidas no art. 55 da Constituição Federal de 1988". Esses autores abordam a matéria exatamente com a perspectiva histórica e originalista proposta nesta tese:

“A Emenda Constitucional 1/69 incluiu na Constituição Federal de 1967 o princípio da fidelidade partidária. E por força desse princípio, o art. 152 previa a perda do mandato do deputado que deixasse a legenda pela qual fora eleito. Entretanto, o instituto da fidelidade partidária, associado àquela previsão legal então vigente, servia como instrumento de perseguição política do regime militar, o que lhe rendeu acirradas críticas não só no ambiente político como também entre juristas de renome.

Novamente firmado o espírito democrático, a EC 25/85 revogou o inc. $\mathrm{V}$ do art. 35 que previa a perda do mandato por infidelidade partidária.

O legislador constituinte responsável pela Carta Magna de 1988, impregnado pelas então recentes experiências vividas sob o regime militar, deixou de fora desse importante diploma constitucional, nomeadamente do art. 55, a perda do mandato por desfiliação partidária, não obstante preservado o acentuado valor reservado ao princípio da representação partidária.

Diante dessa circunstância, é possível afirmar com segurança que a atual Constituição, intencionalmente, não incluiu a desfiliação partidária como causa de perda de mandato. Em outras

${ }^{429}$ Curso de Direito Constitucional Positivo, 33a. ed., 2010, p. 407. E o autor reitera o mesmo entendimento nas edições mais recentes de seus Comentários Contextuais à Constituição, sem fazer nenhuma referência à nova orientação jurisprudencial.

${ }^{430}$ Curso de Direito Constitucional, 5a . ed., 2009, p. 794. 
palavras, não é possível falar em lacuna legal ou omissão involuntária do legislador constituinte a esse respeito." ${ }^{, 431}$

\subsubsection{Uma crítica originalista}

A nova postura do STF e do TSE, como já dissemos, não foi uma simples mudança de jurisprudência. Trata-se, claramente, da criação de uma nova hipótese de perda de mandato, não prevista na Constituição, contrariando de modo frontal uma decisão conscientemente tomada pela Assembléia Nacional Constituinte, que durante dezenove anos foi assim reconhecida pela jurisprudência consolidada do próprio STF e pela quase unanimidade dos doutrinadores.

Estamos de acordo com a posição externada pelo ministro Eros Grau, como relator do Mandado de Segurança n. 26.602-2, no item 14 de seu voto: o Supremo Tribunal Federal criou, "por via oblíqua, hipótese de perda de mandato parlamentar não prevista no texto constitucional", assumindo a condição de legislador, por meio de decisão pela via mandamental. E tanto isso é verdade que, durante o julgamento, o mesmo ministro perguntou "desafiadoramente" ao ministro Marco Aurélio, que mostrasse “onde está escrito, na Constituição ou em qualquer lei, que o cancelamento de filiação partidária ou a transferência do candidato eleito por um partido para outra legenda consubstancia renúncia tácita?”. O ministro Marco Aurélio citou, então, o art. 26 da Lei 9.096/95, do seguinte teor: "Art. 26. Perde automaticamente a função ou cargo que exerça, na respectiva Casa Legislativa, em virtude da proporção partidária, o parlamentar que deixar o partido sob cuja legenda tenha sido eleito”.

Diante dessa óbvia objeção, imediatamente levantada pelos ministros Eros Grau, Ricardo Lewandowski e Gilmar Mendes, de que "função ou cargo", no caso, não se referiam ao mandato, mas a cargos de direção ou representação

${ }^{431}$ Legislação Eleitoral Interpretada, 33 . ed., 2010, p. 208 (destaques nossos). 
em comissões legislativas (por isso que resultantes "da proporção partidária") ${ }^{432}$, o ministro Marco Aurélio limitou-se a dizer que era "uma visão" que respeitava. Ao menos naquele momento, a desafiadora questão ficou sem resposta - e isto porque, efetivamente, resposta não há.

São lapidares as considerações do ministro Eros Grau, no aditamento a seu voto no Mandado de Segurança n. 26.602-2, alertando para o erro de disfarçar, mediante apelo a princípios, a prevalência de posições pessoais dos julgadores, enxergando na Constituição aquilo que ela não contém:

"Não vejo como, na qualidade de guardião da Constituição, este Tribunal conceder a segurança. Não vejo também como transformarmos o mandado de segurança em ação declaratória para o feito de, obter dictum ou não, dizer aquilo que eu gostaria de dizer enquanto cidadão, que a fidelidade partidária é conveniente etc. Não, essa não é a nossa função aqui.

Estou inteiramente convicto de que, infelizmente --- digo-o agora como cidadão ---, o instituto da fidelidade partidária não foi contemplado a este ponto. E eu devo cumprir a Constituição. Meu compromisso é com a Constituição. Não posso ir além do que ela me autoriza a ir, porque só tenho legitimidade para me manter dentro dos meus limites, interpretando-a nos limites do texto."

Os outros dois ministros que proferiram votos vencidos, no julgamento dos mandados de segurança, incluíram expressamente em sua fundamentação a abordagem objeto de nossa análise.

O ministro Lewandowski relembrou o contexto histórico da redemocratização e a o intuito do constituinte de 1988 de preservar "o espírito que

\footnotetext{
${ }^{432}$ Consideramos altamente improvável que o ministro Marco Aurélio admita a perda "automática" do mandato, como diz esse dispositivo. Claramente, "função ou cargo" que sejam exercidos "na respectiva Casa", e "em virtude da proporção partidária" (ou seja, do tamanho das bancadas), não pode, de forma alguma, referir-se a mandato popular. O incorreto argumento já havia sido previsto e convincentemente rebatido - por Luis Carlos Muta: "Trata-se, no entanto, não de perda de mandato eletivo, mas tão-somente da função ou cargo, pertencente à representação partidária, nos órgãos internos da Casa Legislativa (Mesa, Comissões etc.), daí porque adequado o preceito, sem risco de inconstitucionalidade diante da interpretação firmado quanto ao caráter exaustivo das hipóteses do artigo 55 da Constituição Federal” (Direito Constitucional, t. I, 2007, p. 205).
} 
presidiu a elaboração da EC n. 24/85, adotada no ambiente de redemocratização, deixando de incluir no rol do art. 55 da Carta Magna (...) qualquer sanção por infidelidade partidária".

Por sua vez, o ministro Joaquim Barbosa asseverou:

“...não me parece adequado resolver a questão posta nos autos à luz de princípios supostamente implícitos na nossa Constituição. A razão para isso é muito simples. É que, a meu ver, o constituinte de 1988 disciplinou conscientemente a matéria, e fez a opção deliberada de abandonar o regime de fidelidade partidária que existia no sistema constitucional anterior, que previa a perda do mandato nesses casos. Optou, nos artigos 55 e 56 da Constituição, por dizer de maneira exaustiva quais são as hipóteses de perda do mandato pelo parlamentar eleito pelo voto popular. Dentre essas hipóteses, não figura a perda por infidelidade partidária, como bem já decidiu esta Corte diversas vezes". 433

A mesma linha interpretativa, aliás, já fora seguida pelo ministro Marcelo Ribeiro, do Tribunal Superior Eleitoral, único a ficar vencido na resposta à Consulta n. 1.398:

"Não me parece haver espaço para invocar princípios implícitos quando a matéria foi tratada expressamente na Constituição anterior e a alusão à perda de mandato, de modo claro, foi retirada da atual Constituição.

Parece-me, com a devida vênia, que o constituinte não quis que essa hipótese, de mudança de partido pelo parlamentar eleito, acarretasse a perda do mandato.

(...) embora louve toda argumentação no sentido de se prestigiar a fidelidade partidária, não encontro razões no direito posto que autorizem a conclusão a que chegaram os doutos votos vencedores".

${ }^{433}$ Voto no Mandado de Segurança n. 26.602 (os destaques são nossos). 
O recurso à argumentação principiológica parece-nos, no caso, pouco consistente. Há outros princípios em jogo - explícitos na Constituição - como o da inviolabilidade do mandato ( art. 53) e sua natureza representativa, já que os deputados são representantes de todo o povo (art. 45), enquanto os senadores represenam os Estados e o Distrito Federal (art. 46). Não são eles representantes apenas de seus eleitores, muito menos de seus partidos.

Não é sem razão que Walter Costa Porto, ao analisar o art. 152 da Emenda Constitucional n. 1/69, que pela primeira vez implantou a perda de mandato por infidelidade partidária, assinala que "sempre se argumentou que o dispositivo entrava em conflito com a essência e a estrutura do texto constitucional, com a inviolabilidade do exercício dos mandatos de Deputados e Senadores e, com respeito a estes, com o art. 41 da Carta, que os declarava representantes dos Estados". ${ }^{434}$

Para contornar a vetusta regra, segundo a qual as normas que estabelecem restrições de direitos devem ser interpretadas restritivamente - e aqui, não custa lembrar, estamos a cuidar de direito fundamental - vários dos ministros que compuseram a maioria, seja no TSE, seja no STF, tiveram o cuidado de ressaltar que não pretendiam criar uma nova hipótese de "perda de mandato", mas apenas reconhecer a ocorrência de "renúncia tácita". Trata-se, a nosso ver, e com a máxima vênia, de simples eufemismo, em defesa antecipada contra as críticas que os ilustres julgadores receavam receber, diante de uma postura tão claramente ativista.

A escolha de palavras mais amenas não tem o condão de alterar a realidade. Quando consolidada a nova opção do STF, o TSE editou a Resolução n. 22.610, de 25 de outubro de 2007, disciplinando "o processo de perda de cargo eletivo, bem como de justificação de desfiliação partidária". 435 É disto que realmente se trata, conforme aponta, sem eufemismos, Alexandre de Moraes: na nova sistemática, os

\footnotetext{
${ }^{434}$ Dicionário do Voto, Unb, 2000, p. 207.

${ }^{435} \mathrm{O}$ destaque em negrito é nosso. A "perda de cargo" passou então a se aplicar, inclusive, aos chefes de Poder Executivo, eleitos pelo sistema majoritário (portanto, sem maior peso da legenda), em virtude do decidido pelo TSE na Consulta n. 1.407.
} 
partidos políticos "podem requerer à Justiça Eleitoral a cassação do mandato do parlamentar infiel e imediata determinação de posse do suplente". 436

Discordamos da tese de que a mudança de partido signifique "renúncia tácita", e para prová-lo basta lembrar que se admite o oferecimento de defesa, com vistas a demonstrar a ocorrência de uma das justificativas aceitas pelo TSE. Somente há renúncia se esta for voluntária, e não há voluntariedade se o suposto "renunciante" resiste à perda do mandato e luta pela sua manutenção.

Ademais, há conhecidos casos de parlamentares que, mesmo após as resoluções do TSE, pediram desfiliação do partido pelo qual eleitos e transferiramse para outra legenda, continuando, porém, no pleno exercício do mandato. Onde a "renúncia tácita”?

Não contestamos os elevados propósitos, de inspiração moralizante, do recente posicionamento do Tribunal Superior Eleitoral e do Supremo Tribunal Federal. A questão que mais nos preocupa não é tanto o resultado alcançado, mas o método que foi adotado. Mais uma vez, considerações de ordem política prevaleceram sobre a razão jurídica. Desprezou-se a vontade do constituinte e recorreu-se a uma linha argumentativa nada convincente, apelando a princípios "supostamente implícitos" (como disse o ministro Joaquim Barbosa), enquanto outros princípios, estes sim expressos na Constituição, foram simplesmente deixados de lado.

Inegavelmente é melhor para o país, para o fortalecimento das instituições e para o respeito à vontade do eleitor, que os representantes eleitos por um partido permaneçam filiados - e fiéis - à agremiação pela qual obtiveram o mandato eletivo.

A medida, porém, pouco significa sem uma mudança ampla e coerente de todo o sistema eleitoral, que fortaleça os partidos políticos ${ }^{437}$ e faça efetivamente prevalecer a vontade do eleitor. Recorde-se a advertência de Celso

\footnotetext{
${ }^{436}$ Direito Constitucional, 24a ${ }^{\text {a }}$ ed., p. 265.

${ }^{437}$ Sem no entanto deles fazer o eixo central do poder, como defendem os adeptos da chamada "democracia partidária". Como bem adverte o ministro Joaquim Barbosa, no voto proferido no MS 26.602-2, a Constituição reconhece a soberania do povo, não dos partidos.
} 
Bastos quanto a aspectos negativos que também podem advir da exacerbação das regras de fidelidade partidária, e que devem ser levados em conta numa reforma global e abrangente de todo o sistema eleitoral.

O problema maior, como dissemos, está no método empregado para essa reforma pontual: uma súbita modificação de jurisprudência consolidada, com inevitáveis prejuízos para o princípio da segurança jurídica, e manifesto desacordo com a decisão do poder constituinte - que, bem ou mal, mas legitimado diretamente pela soberania popular, adotou solução inteiramente diversa.

Não se trata, como pareceu a Uadi Lammêgo Bulos, de falta de previsão expressa; na verdade, tratou-se de consciente exclusão, dentre as hipóteses de perda de mandato, dos atos de infidelidade partidária. Sabia muito bem o constituinte o que estava a fazer: prestigiou a fidelidade partidária como valor constitucional, obrigando os partidos a incorporá-la em seus estatutos, bem como a estabelecer sanções internas para a sua inobservância. Esta foi a decisão do povo, por meio de seus legítimos representantes.

Claro que em 1985 - quando abolida a perda de mandato por infidelidade partidária - ou em 1988 - quando a Assembléia Constituinte rejeitou proposta de reinstaurá-la -, era diferente a situação do país. Sem nenhum rigor lógico, tudo que fosse proveniente do regime constitucional anterior era automaticamente associado a rótulos como "entulho autoritário", sem separar o joio do trigo. Hoje, mais de duas décadas depois, percebeu-se que a disciplina e a fidelidade partidárias são valores essenciais à democracia. Mas seria adequado que um ato de infidelidade - como, por exemplo, a troca de partido - leve à extinção do mandato popular? Essa consequência, que nos parece excessivamente drástica, nos parece não fazer sentido se adotada - como o foi - isoladamente, sem a implantação simultânea e harmoniosa de outras importantes reformas, como a implantação do voto distrital e da cláusula de barreira, de modo a realmente favorecer a consolidação de autênticos partidos políticos.

A análise histórica do texto constitucional, em matérias como esta, sem dúvida muito enriqueceria o debate, auxiliando o intérprete a buscar soluções equilibradas, que não extrapolem os limites da divisão de poderes e não façam a 
Suprema Corte, tal como disse o ministro Eros Grau, "ir além" do que lhe autoriza a Constituição.

Embora inegáveis os intuitos moralizadores da decisão do STF, bem como sua majoritária aceitação, é preciso lembrar que ela também apresenta pontos negativos. Retornamos ao sistema tão combatido no regime militar, em que o parlamentar era visto como um "porta-voz do partido", com patente distanciamento da teoria clássica sobre o mandato político ${ }^{438}$. Foi drasticamente abreviado, senão suprimido, o saudável debate sobre a matéria, importante para a educação política do povo brasileiro. Adotamos um perigoso precedente de emenda judicial da Carta Política. E, sobretudo, ficou o Congresso Nacional ciente de que poderá, daqui por diante, deixar para o STF o ônus de efetuar autênticas reformas na Constituição ${ }^{439}$, o que poderá ser particularmente perigoso se, num futuro próximo, tivermos uma composição monolítica da Suprema Corte. ${ }^{440}$

Por que não percorrer o caminho mais adequado - ainda que mais longo - da lenta e segura conscientização popular, a viabilizar posterior emenda à Constituição? A solução mais rápida, pela via judicial, privou a cidadania de uma conquista que seria mais meritória e mais duradoura se precedida pelo debate saudável e paulatina conquista da opinião pública, que fatalmente iria se refletir no ambiente parlamentar. Pode-se dizer que respeita a Constituição uma decisão que, a despeito de suas boas intenções, contraria frontalmente a vontade do poder constituinte?

\footnotetext{
${ }^{438}$ Manoel Gonçalves Ferreira Filho, Curso, cit. p. 180.

${ }^{439}$ Nesse sentido, a professora Vanice Lírio do Valle declarou, em entrevista ao jornal Folha de S. Paulo, que o Legislativo preferiria o "ônus da inércia" ao "ônus de desagradar parte do eleitorado com decisões polêmicas" ("Omissão do Legislativo dá espaço à supremocracia" - ed. 4.5.2009).

${ }^{440}$ De "terceira câmara do Congresso", como às vezes já se tem chamado o STF, em razão de este assumir, cada vez mais (e a nosso ver, indevidamente) atribuições tipicamente legislativas, poderemos assistir, num futuro não muito distante, à transformação da Corte Suprema em "câmara única" do parlamento, quando este último não quiser arcar com desgastes políticos, inevitáveis quando se toma decisões em matérias sujeitas a acesa controvérsia. Resultará muito mais cômodo deixar para o STF decidir, por exemplo, sobre descriminalização do aborto ou do uso de drogas, adoção de critérios raciais para estabelecimento de privilégios ou "casamento" entre pessoas do mesmo sexo. Seria - ou será? - uma conjugação muito conveniente entre os interesses de parlamentares omissos e os objetivos de organizações sociais ativistas, extremamente organizadas mas com escassas perspectivas de obter amplos consensos sociais. Desnecessário dizer que, num tal arranjo, a democracia será a grande derrotada.
} 
Muito adequada, a esse respeito, a observação de Janine Adeodato Accioly, em monografia dedicada ao tema:

“...apesar de reconhecer como bem intencionado o entendimento do egrégio TSE, crê-se que a adoção de uma interpretação respaldada nos princípios não reflete, nesse caso, a verdadeira intenção do legislador constituinte, sendo relevante ressaltar, inclusive, que apesar de a Constituição já contar com 20 anos desde a sua promulgação, apenas agora o Poder Judiciário, sem qualquer alteração constitucional, inovou esse entendimento, embora já instado a manifestar-se em outras oportunidades". ${ }^{441}$

Há ainda outra questão, tão relevante quanto incômoda: não seria também um desrespeito à vontade do eleitor decretar a perda de mandato de um representante legitimamente eleito, fora das exceções expressamente autorizadas pelo texto constitucional? No Brasil, como é notório, o vínculo entre o eleitor e o candidato tem sido, historicamente, muito mais forte do que a relação entre eleitor e partido político - especialmente no caso de cargos executivos, aos quais o TSE, como já visto, estendeu a sanção de perda do cargo, na hipótese de transferência de partido.

O tema da fidelidade partidária é de complexidade ímpar, a reclamar ponderada decisão política, embasada em reflexão de toda a sociedade. Não é assunto para ser decidido pelos tribunais. ${ }^{442}$

O estabelecimento da sanção de perda do mandato em virtude de desfiliação partidária, por via jurisprudencial, apresenta os típicos problemas das medidas isoladas, incapazes de produzir os efeitos almejados exatamente porque lhes falta o indispensável apoio de medidas correlatas, editadas de forma abrangente e

${ }^{441}$ Perda de Mandato Eletivo por Infidelidade Partidária, p. 30. Escola Superior da Magistratura do Estado do Ceará, Fortaleza, 2009 (disponível em www.bdjur.tjce.gov.br).

${ }^{442}$ Registre-se que, em outubro de 2007, o Senado aprovou por unanimidade (56 votos em primeiro turno, e 58 em segunda votação) a PEC n. 23/2007, de autoria do Senador Marco Maciel, com substitutivo do Senador Tasso Jeressaiti, alterando os arts. 17 e 55 da Constituição para fazer constar expressamente a possibilidade de perda de mandato por infidelidade partidária. Vários senadores referiram-se, então, a importância de o Poder Legislativo comandasse a reforma política. Parece-nos que tal proposta visa não somente ratificar, mas também legitimar a nova orientação do STF e do TSE. 
sistêmica $^{443}$. A troca de partido durante o mandato pode ser a mais notória, mas não é a única forma de manifestação de infidelidade. Como vimos no início deste tópico, o parlamentar que afrontar as diretrizes partidárias em questões vitais - como na votação de projetos importantes, ou no apoio a candidaturas de partidos adversários, em eleições majoritárias ou escolha de dirigentes das casas legislativas - conservará seu mandato, em que pese tais atitudes serem, muito provavelmente, mais gravosas à disciplina e à fidelidade do que a ostensiva troca de legenda.

Dito de outro modo: apesar da decisão do Supremo, a infidelidade continuará, algo disfarçada, manifestando-se nas votações e no apoio político a partidos adversários, sem no entanto chegar ao limite da desfiliação.

Ademais, nos dias que correm é notória a inutilidade de prever punição ao parlamentar infiel, quando muito mais séria se afigura a hipótese lamentavelmente, cada vez mais comum - do partido infiel ${ }^{444}$, que renega coletivamente seu próprio programa, fraudando a vontade de seus eleitores.

Indagou o ministro Cezar Peluso, ao votar na Consulta n. 1.398:

"Onde fica a função representativa dessas correntes de opiniões que os partidos, como corpos intermediários, estão destinados a desempenhar? Se o candidato, eleito por ter-se comprometido com determinado ideário político, mudar, uma vez diplomado e empossado, imediatamente para partido com ideário completamente diferente, demonstra, com isso, que não dá a mínima importância aos eleitores que nele depositaram o voto de confiança de que sustentaria aqueles ideais no parlamento."

O eminente ministro, reconhecidamente um dos mais técnicos da Suprema Corte, envereda nesta passagem por um raciocínio que nos parece perigoso. Tomando por base tais premissas - apenas para fins de argumentação - ousamos então

\footnotetext{
${ }^{443}$ Nesse sentido é a advertência do ministro Nelson Jobim, em trecho de conferência citado no voto do ministro Lewandowski no MS 26.602: "Falar-se em fidelidade partidária, sem ter a consciência real do que se passa no processo de escolha dos candidatos é um equívoco. Precisamos ter noção do que se passa, para colocar sobre a mesa a discussão de temas como distrito eleitoral, sistema de eleições mistas etc.; debater claramente esse tipo de situação para entendermos o que se passa em termos político-eleitorais no país".

${ }^{444}$ V. Roberto Amaral e Sérgio Sérvulo da Cunha, Manual das Eleições, 3a. ed., Saraiva, 2006, p.697.
} 
perguntar: a quem competirá avaliar se o novo partido tem "ideário completamente diferente”? A nosso ver, somente uma resposta é admissível: ao eleitor. Qualquer outra solução, além de apartar-se da Constituição, traz implícita a pouca confiança no processo democrático. Cremos que ao Judiciário não cabe, de modo algum, avaliar o mérito de opções políticas.

Muitas vezes, levar adiante um argumento é o melhor modo de testar sua validade e consistência. Se a mudança de postura ideológica constitui, na visão da maioria dos ministros do TSE e do STF, causa suficiente para perda do mandato parlamentar, o que deveria ocorrer se um partido, em bloco, trair o ideário e as promessas constantes de seu programa? A Justiça Eleitoral declararia extinta sua representação no Congresso Nacional? A pergunta é meramente retórica, mas serve para ilustrar a situação paradoxal a que se chegou: de um lado, castiga-se severamente a infidelidade de um, atingindo um direito fundamental sem que para tanto haja previsão expressa na Constituição; de outro, e um tanto incoerentemente, a infidelidade coletiva permanecerá impune. Tomando-se de empréstimo a terminologia do Direito Penal, neste caso o “concurso de agentes" atuará como causa excludente de ilicitude...

É ponto pacífico a necessidade de prestigiar o fortalecimento das instituições e fazer valer a vontade do povo expressa nas urnas. Há mais de um modo, porém, de se alcançar esses objetivos, e as soluções mais rápidas não são, normalmente, as mais duradouras.

\subsection{Reinterpretação da Lei de Anistia}

O julgamento da Arguição de Descumprimento de Preceito Fundamental n. 153-DF, em sessões realizadas em 28 e 29 de abril de 2010, constitui o mais eloqüente e significativo caso de adoção, pelo Supremo Tribunal Federal, de um enfoque interpretativo originalista. Trata-se do exato contraponto dos mandados de segurança julgados em 2007, em que foi introduzida a extinção do mandato 
parlamentar por infidelidade partidária. Se naquele caso, como já visto, a maioria dos ministros do Supremo não levou em conta o sentido original da Carta Magna, fazendo tabula rasa da intenção claramente manifestada pelo constituinte, desta feita adotouse, por ampla maioria, critério interpretativo exatamente oposto: para resolver o ponto decisivo da controvérsia constitucional, nada menos do que sete ministros recorreram à análise da intenção do legislador, em harmonia com o entendimento original da norma e o contexto histórico em que ela foi editada, recorrendo inclusive a testemunhos dos que viveram aquele momento. E essa busca do sentido original já estava presente antes mesmo da sessão de julgamento, em substanciosas manifestações da Advocacia-Geral da União e da Procuradoria-Geral da República.

\subsubsection{O sentido original da norma}

$\mathrm{O}$ art. $1^{\circ}$. da Lei n. 6.683, de 28 de agosto de 1979, concedeu “anistia a todos quantos, no período compreendido entre 02 de setembro de 1961 e 15 de agosto de 1979, cometeram crimes políticos ou conexos com estes, crimes eleitorais, aos que tiveram seus direitos políticos suspensos", bem como a servidores públicos, civis e militares, além de dirigentes sindicais, punidos com fundamento em Atos Institucionais e Complementares. A seguir, seu $\S 1^{\circ}$ declarava que deveriam ser considerados "conexos, para o efeito deste artigo, os crimes de qualquer natureza relacionados com crimes políticos ou praticados por motivação política", excetuandose expressamente dos benefícios da anistia, no $\S 3^{\circ}$, "os que foram condenados pela prática de crimes de terrorismo, assalto, sequestro e atentado pessoal".

Rememorando as circunstâncias em que aprovada essa lei, Glenda Mezarobba narra que, após o envio do projeto pelo presidente Figueiredo, diversas críticas eram-lhe dirigidas: ora sobre as restrições a alguns tipos de crimes (como atos de terrorismo), ora quanto à intenção de perdoar os torturadores, por meio da expressão "crimes conexos"; durante toda a tramitação do projeto, houve grande 
empenho no sentido de "ampliar o caráter da anistia, considerado pela oposição como restrito e incompleto". 445

Esse intento estava significativamente expresso no mote que se tornou célebre, repetido incessantemente em discursos parlamentares, passeatas, comícios e assembléias: "Anistia ampla, geral e irrestrita". ${ }^{446}$

Por outro lado, durante a discussão e votação do projeto era muito clara a compreensão de que a referência a "crimes conexos" destinava-se a anistiar os atos de tortura ou outros delitos cometidos por agentes da repressão - tanto é assim, que críticas foram endereçadas a essa cláusula, e até apresentado um substitutivo que a excluía $^{447}$. O fato de haver sido rejeitada essa emenda também evidencia qual foi o intuito do legislador.

Logo após o envio do projeto pelo Poder Executivo, o ministro Gualter Godinho, do Superior Tribunal Militar, manifestava a opinião de que a referência a crimes conexos, no mencionado $\S 1^{\circ}$,

“À evidência, (....) importa em serem abrangidos pelo benefício da anistia, de um modo geral, todos quantos cometeram delitos relacionados com os crimes políticos, isto é, todas as partes neles envolvidas, inclusive os que possam ser acusados da prática de sevícias ou de torturas". ${ }^{448}$

A generalizada aceitação desse entendimento foi registrada por historiadores.

${ }^{445}$ Glenda Mezarobba, Um Acerto de Contas com o Futuro: A Anistia e suas Consequências - Um Estudo do Caso Brasileiro. Dissertação - USP, 2003, p. 34.

446 "Os entusiastas da anistia apareciam onde quer que houvesse uma multidão. Nos campos de futebol suas bandeiras com a inscrição Anistia ampla, geral e irrestrita eram desfraldadas onde as câmaras de TV pudessem focalizá-las" (Thomas Skidmore, Brasil: De Castelo a Tancredo, Paz e Terra, $8^{\text {a }}$. ed., 2008, p. 423).

${ }^{447}$ Glenda Mezarobba, ob. e loc. cit.

${ }^{448}$ Considerações sobre o projeto de anistia política, Revista do Superior Tribunal Militar, vol. 6, 1980, pp. 69-73. 
Comenta Bóris Fausto que "ao anistiar 'crimes de qualquer natureza relacionados com crimes políticos ou praticados por motivação política', a lei abrangia também os responsáveis pela prática da tortura"; tratava-se de "uma importante concessão à linha dura", que no entanto permitiu, em contrapartida, "a volta dos exilados políticos" e a "ampliação das liberdades públicas". 449 O emprego do termo "concessão" confirma que o processo que levou à anistia foi objeto de negociação política, não de imposição.

Da mesma forma, Thomas Skidmore confirma que a referência a crimes conexos, com o fim já mencionado, foi pactuado entre as diversas lideranças políticas, incluindo as de oposição:

"A questão de uma possível ação contra os torturadores foi de fato resolvida pela inclusão na lei de anistia de uma definição que incluía os praticantes tanto de 'crimes políticos' quanto de 'crimes conexos', este último eufemismo em geral entendido como um artifício para dar cobertura aos torturadores. Foi uma transação política. Os líderes da oposição sabiam que só podiam passar a um regime aberto com a cooperação dos militares". ${ }^{450}$

Ronaldo Costa Couto, escrevendo em 1998, após rememorar as circunstâncias do "longo processo de entendimento", assinala como foi o desfecho de toda negociação havida entre governo e oposição:

"Chega-se ao projeto possível naquele momento. Nasce a Lei n. 6.683, de 28 de agosto de 1979. Ela não anistia os participantes da guerrilha envolvidos em crimes de sangue nem manda libertar automaticamente os condenados por tentativa de reorganização de partido político ilegal, nos termos da Lei de Segurança Nacional. Os militares afastados por motivos políticos passam a receber aposentadoria(....) Quanto aos funcionários públicos civis, inclusive diplomatas e professores universitários, podem reassumir as funções, desde que haja aprovação de comissão de

\footnotetext{
${ }^{449}$ Bóris Fausto, História do Brasil, 1994, p. 504. O termo "concessão",

${ }^{450}$ Brasil: de Castelo a Tancredo, cit., p. 426.
} 
inquérito especial. E, muito importante, inclui dispositivo que contempla também os autores de crimes praticados por intermédio do aparelho repressivo, inclusive tortura, ao anistiar 'crimes de qualquer natureza relacionados com crimes políticos ou praticados por motivação política'. Anistiou bilateralmente”.

E cita, para comprová-lo, o insuspeito depoimento do Deputado José Genoíno, ele próprio ex-guerrilheiro anistiado, que por sinal teve destacada atuação como constituinte:

"Toda a transição foi pactuada no sentido de não julgar os envolvidos na repressão política. Tanto que isso não aconteceu nem depois do fim da ditadura. A anistia foi concebida nessa linha". 451

O entendimento original quanto ao exato sentido da cláusula dos "crimes conexos", bem como o caráter bilateral e recíproco da anistia, foram bem enfatizados em parecer enviado pela própria Ordem dos Advogados do Brasil, em 15 de agosto de 1979, ao Senado Federal, de autoria do então Conselheiro José Paulo Sepúlveda Pertence, do qual destacamos os seguintes trechos:

“14. Ora, não há objeção retórica que possa obscurecer que a amplitude, com a qual o mencionado $\S 1^{\circ}$ definiu, como conexos nos crimes políticos, os crimes de qualquer natureza com eles relacionados, tem o único sentido de prodigalizar a anistia aos homicídios, violências e arbitrariedades policiais de toda a sorte, perpetrados nos desvãos da repressão política.

(...) amplia-se ineditamente o conceito de crime comum conexo a crimes políticos, para beneficiar com a anistia, não apenas os delitos comuns de motivação política (o que encontra respaldo nos precedentes), mas também, com o sentido já mencionado, os que tenham, com os políticos, qualquer tipo de relação.

17. Nem a repulsa que nos merece a tortura impede reconhecer que toda a amplitude que for emprestada ao

${ }^{451}$ História indiscreta da ditadura e da abertura, ed. Record, 1998, p. 278. 
esquecimento penal desse período negro de nossa História poderá contribuir para o desarmamento geral, desejável como passo adiante no caminho da democracia."

Esse parecer teria imenso relevo no julgamento da ADPF 153. Sua reiterada citação, às vezes com longas transcrições, nos pareceres da Advocacia-Geral da União e da Procuradoria-Geral da República, bem como em todos os votos que compuseram a maioria (ministros ministros Eros Grau, Cármen Lúcia, Gilmar Mendes, Ellen Gracie, Marco Aurélio, Celso de Mello e Cezar Peluso), fez as vezes de testemunho autorizado do entendimento original da norma impugnada, tal como, no direito norte-americano, são invocados discursos ou pronunciamentos da época em que redigida e ratificada a Constituição, como fonte para descoberta do verdadeiro sentido de suas provisões. $\quad \mathrm{O}$ próprio ministro Pertence teve ocasião de reiterar a manifestação que subscrevera há três décadas, pouco antes do julgamento da argüição. $^{453}$

Observe-se que o sentido de pacificação e concórdia mencionado nesse parecer já havia sido antecipado, dois anos antes (quando ainda vigorava o AI-5 e o Congresso fora fechado pelo Presidente Geisel), pelo então presidente da OAB, Raymundo Faoro, ao falar da possibilidade de redemocratização: "A Constituinte é um dos caminhos. Mas não é o único (...) A anistia é um passo dessa pacificação" ${ }^{454}$

\subsubsection{A constitucionalização da anistia.}

A matéria foi alçada a nível constitucional com a Emenda n. 26, de 27 de novembro de 1985, convocando para o ano imediato a eleição da Assembléia Constituinte, e declarando, em seu artigo $4^{\circ}$, que era "concedida anistia a todos os

\footnotetext{
${ }^{452}$ Os destaques são nossos.

${ }^{453}$ Carta Maior, 18.1.2010, disponível no endereço eletrônico www.cartamaior.com.br/templates/materiaMostrar.cfm?materia_id=16339)

${ }^{454}$ Jornal da Tare, 12.9.1977, p. 14 (apud Élio Gáspari, A Ditadura Encurralada, cit., p. 450.
} 
servidores públicos e civis da Administração direta e indireta e militares, punidos por atos de exceção, institucionais ou complementares", mantendo, no seu parágrafo $1^{\circ}$, sua extensão "aos autores de crimes políticos ou conexos".

Essa Emenda Constitucional, em verdade, ampliou consideravelmente a anistia, ao não renovar as exceções anteriormente previstas no art. $1^{\circ}$., $\S 3^{\circ}$ da lei (condenação por "terrorismo, assalto, seqüestro e atentado pessoal”), bem como prever promoções retroativas e direito a indenizações.

Assim, o poder constituinte derivado - inegavelmente conhecendo a amplitude com que seis anos antes havia sido editada - e compreendida - a anistia, manteve expressamente a referência aos "crimes conexos" 455 .

Por fim, o art. $8^{\circ}$. do Ato das Disposições Constitucionais Transitórias de 1988 aumentou ainda mais a abrangência da anistia, fazendo-a retroagir até 1946, para alcançar todos os que haviam sido atingidos por ato de exceção, em decorrência de motivação exclusivamente política, assegurando as promoções a que teriam direito nesse período, em qualquer "cargo, emprego, posto ou graduação", inclusive em atividades profissionais na vida civil. A falta de qualquer menção a condutas criminais, nesse dispositivo, somente podia significar a plena manutenção da anistia anteriormente concedida.

E assim a questão foi entendida pelos tribunais, inclusive em relação aos "crimes conexos". Exemplo disso foi a concessão de habeas corpus, pelo Tribunal de Justiça de São Paulo, para trancar inquérito policial requisitado pelo Ministério Público para investigar a autoria de homicídio do jornalista Vladimir Herzog, ocorrido em 25 de outubro de 1975 em dependências policiais; a ordem foi concedida, por unanimidade, exatamente sob o argumento de que o delito estava

\footnotetext{
${ }^{455}$ Mesmo não repetindo o texto contido no parágrafo $1^{\circ}$. do art. $1^{\circ}$. da Lei n. 6.683/79, a Emenda 26/85, dado o seu caráter ampliativo da anistia, implicitamente manteve aquela conceituação, conforme anotado no parecer da Advocacia-Geral da União, oferecido na ADPF 153.
} 
coberto pela anistia, na condição de "crime conexo ao crime político ou por motivação política praticado". ${ }^{456}$

\subsubsection{O surgimento da controvérsia}

Desde o início da década de 1990 registraram-se manifestações no sentido de revisar a Lei de Anistia, defendendo que esta não fosse aplicada a agentes da repressão política - notadamente aos que tivessem praticado tortura ou homicídio contra opositores do regime militar.

Assim é que, já em 1992, Dalmo de Abreu Dallari sustentava haver chegado o "tempo de considerar a validade e o alcance da anistia concedida em 1979, que vem sendo invocada como obstáculo" para a punição de torturadores. E defendia, desde logo, que a anistia não se aplicaria a delitos de homicídios, uma vez que estes haveriam de ser julgados pelo Tribunal de Júri, e "uma lei ordinária não poderia tirar desse Tribunal a competência para o julgamento desses crimes". Daí porque - ainda segundo Dallari - "os torturadores homicidas, e possivelmente outros, nunca foram anistiados". 457

${ }^{456}$ TJSP, Quarta Câmara Criminal, Habeas Corpus n. 131.798-3/2, j. 13.10.1992, Quarta Câmara Criminal, rel. desembargador. Péricles Piza; também votaram, acompanhando o relator, os desembargaodres Barreto Fonseca (presidente) e Augusto Marim. Ao não conhecer do recurso impetrado contra esse acórdão, o Superior Tribunal de Justiça admitiu que justificava-se o trancamento de inquérito policial por meio de habeas corpus quando "às claras se mostre a extinção da punibilidade por força de anistia" (Recurso Especial n. ${ }^{\circ}$ 33.782-7 - SP, j. 18/08/93, $5^{\text {a }}$ Turma, v.u., rel. Min. José Dantas).

${ }^{457}$ Crimes sem Anistia - artigo publicado na Folha de S. Paulo, 18.12.1992, p. 3, e também na coletânea Mortos e desaparecidos políticos - reparação ou impunidade?", organizada por Janaína Teles (2 $2^{\text {a }}$ ed., 2001, ed. Humanitas, pp. 31-33). O argumento, com a devida vênia, parece-nos totalmente equivocado: em primeiro lugar, porque a competência do Congresso para conceder anistia era também prevista na Constituição da EC 1/69, vigente à época, e não tinha nenhum tipo de restrição, conforme o órgão judiciário encarregado do julgamento do crime. Em segundo lugar, ainda que houvesse uma tal restrição, a anistia foi constitucionalizada em 1985, com a Emenda 25/85, circunstância que foi inexplicavelmente abstraída pelo ilustre articulista (que, como a seguir veremos, em 2010 parecia já ter refletido melhor sobre a questão). 
Poucos meses depois, Fábio Konder Comparato criticava o “abjeto acordo, firmado entre lideranças partidárias e os chefes militares, para incluir clandestinamente na Lei da Anistia política os policiais e militares que, bem antes da Constituição de 1988, haviam inaugurado a categoria dos crimes hediondos, ao torturarem, estuprarem e trucidarem presos políticos". 458

Em agosto de 1995, em texto encaminhado à Comissão de Justiça e Paz, o mesmo jurista afirmava que era "preciso enfrentar e resolver agora, definitivamente, o problema da pretensa validade e força jurídica da Lei de Anistia de 1979”. E ia além, apresentando pela primeira vez a tese que subscreveria treze anos depois, como advogado da OAB, ao redigir a petição inicial da ADPF 153: sustentava que a lei não se aplicava a delitos como "o homicídio praticado por agentes policiais ou militares, a tortura de presos, ou desaparecimento forçado de pessoas", porque o conceito de conexão criminal, previsto no art. $1^{\circ}$., $\S 1^{\circ}$ da Lei $6.383 / 79$, não teria aplicação nesses casos. E adiantava sua interpretação pessoal sobre o alcance desse instituto:

“A conexão delitiva prevista na lei n. 6.683 não significa uma extensão subjetiva da anistia, o alargamento do benefício a pessoas que não praticaram crimes definidos em lei como políticos. Ela significa, isto sim, a supressão da responsabilidade criminal em relação a infrações que, objetivamente e de modo isolado, não eram de natureza política, como, por exemplo, assalto a bancos, quando tais infrações foram praticadas para custear ações contrárias à segurança nacional.". 459

Numa renovada tentativa de instaurar o debate sobre a matéria, o professor Comparato publicou novo artigo, defendendo de forma mais enfática a inaplicabilidade da anistia a agentes do regime militar:

${ }^{458}$ Ética Política e Honra Militar, Folha de S. Paulo, edição de 8.7.1993, p. 3 (republicado em Janaína Teles, ob. cit., pp. 34-39).

${ }^{459}$ A responsabilidade do Estado brasileiro na questão dos desaparecidos durante o regime militar, in Janaína Teles, ob. cit., pp. 55-63. 
“... a tortura de presos e o desaparecimento forçado de pessoas nunca foram definidos na lei brasileira como crime político. Tampouco podem esses crimes ser considerados tecnicamente conexos com crimes políticos pela boa razão de que não há, no caso, um concurso material de delitos nem co-autoria: os crimes imputados aos opositores políticos não foram meio ou instrumento para a prática de tortura ou assassinato de presos, nem os autores de uns e de outros agiram em conluio." 460

Duas semanas depois, no mesmo órgão de imprensa, o exministro da Justiça José Carlos Dias refutava essas colocações, salientando, além dos princípios basilares da tipicidade e da irretroatividade da lei penal (pois a tortura não era então definida como crime), a intenção com que havia sido redigida e aprovada a Lei de Anistia:

“.... na avaliação do que sejam os chamados crimes conexos que são mencionados na Lei da Anistia (lei n. 6.683), não posso concordar com Comparato, pois que, lembrando como foi a gestação da lei, toda a discussão travada que dividia os debatedores era sobre a abrangência da anistia aos autores das condutas que guardavam qualquer conexão com os delitos políticos, ou seja, as praticadas pelos policiais e militares que enfrentaram os inimigos do regime. A lei trata de conexão que, obviamente, não é de natureza processual, mas sim de conexão legal, material." ${ }^{461}$

Em tréplica, Comparato invocou "o velho princípio de que a intenção do legislador é o mais fraco argumento interpretativo, não podendo jamais prevalecer contra o ditado objetivo da lei", ${ }^{462}$ antecipando precisamente a questão hermenêutica que haveria de ser enfrentada pelo Supremo Tribunal Federal, quinze anos depois, no julgamento da Arguição de Descumprimento de Preceito Fundamental n. 153.

\footnotetext{
${ }^{460}$ Que fizeste de teu irmão? - publicado na Folha de S. Paulo, ed. 13.8.1995, p. 3. (publicado também in Janaína Teles, ob. cit., pp. 64-67).

${ }^{461}$ Os Desaparecidos, Folha de S. Paulo, ed. 3.9.1995, p. 3 (também publicado in Janaína Teles, ob. cit., , pp. 68-72); os destaques são nossos.

${ }^{462}$ Questão de decência, Folha de S. Paulo, ed. 10.9.1995, p.3 (também publica in Janaína Teles, ob. cit., pp. 77-79.
} 
O debate em torno da questão arrefeceu nos anos seguintes, retornando com todo o vigor em 2008, com base, principalmente, em tratados internacionais de direitos humanos subscritos pelo Brasil. Em julho daquele ano, o Ministério da Justiça e a Secretaria Especial de Direitos Humanos da Presidência da República promoveram um seminário com o seguinte tema: "Limites e possibilidades para a responsabilização jurídica dos agentes violadores de direitos humanos durante o estado de exceção no Brasil". Nos dias seguintes, houve manifestações favoráveis à reinterpretação da lei por parte do presidente da Comissão de Anistia, do ministro da Secretaria de Direitos Humanos, do ministro da Justiça e até do juiz espanhol Baltazar Garzón. ${ }^{463}$

A questão despertou grande interesse, retornando às páginas da grande imprensa. ${ }^{464}$

\subsubsection{A questão chega ao STF}

Foi nesse contexto que, em 21 de outubro de 2008, invocando os princípios constitucionais republicano, democrático e da dignidade da pessoa humana, além dos preceitos fundamentais da isonomia em matéria de segurança” e da "proibição de ocultar a verdade", dentre outros, e sustentando a existência de "séria controvérsia constitucional sobre lei federal anterior à Constituição", a Ordem dos Advogados do Brasil ajuizou a Arguição de Descumprimento de Preceito Fundamental n. 153 , pedindo ao Supremo Tribunal Federal que desse ao art. $1^{\circ}$., $\S 1^{\circ}$. da Lei $n$. 6.383, de 28 de agosto de 1979, interpretação conforme à Constituição, para que a anistia nele prevista não abrangesse os crimes comuns praticados por agentes oficiais contra opositores do regime militar.

\footnotetext{
${ }^{463}$ Notícias e depoimentos transcritos pela OAB na petição inicial da ADPF 153.

${ }^{464}$ Apenas a título de exemplo, cite-se matéria publicada na revista Veja, edição de 12 de novembro de 2008, sob o título "Questão fora de lugar - a idéia de revisar o princípio da Lei de Anistia revela a falta de foco do ministro da Justiça". Destaca-se, do teor da matéria, o entendimento manifestado por Ives Gandra da Silva Martins: "com a lei de 1979, tanto os crimes cometidos em nome do regime como os que tinham por objetivo derrubar o governo foram anistiados (...) a tentativa, três décadas depois, de fazer uma punição seletiva é um gesto de vingança, não de justiça."
} 
Curioso observar que a própria entidade autora, embora defendendo uma reapreciação do sentido da norma jurídica, segundo padrões atuais, objetivamente considerados, utilizou argumento de outra índole na petição inicial, ao afirmar que o dispositivo questionado havia sido redigido de maneira "intencionalmente" obscura, utilizando-se da locução "crimes conexos" em sentido atécnico, e não poderia abarcar crimes comuns, como tortura, estupro e homicídio, praticados por agentes públicos contra os opositores do regime militar.

\subsubsection{Os pareceres da AGU e da PGR ${ }^{465}$}

Em manifestação subscrita pelos advogados Ana Carolina de Almeida Tannuri Laferté e Henrique Augusto Figueiredo Fulgêncio, a Advocacia-Geral da União,após levantar preliminares, sustentou que a norma impugnada "surgiu da negociação havida entre a sociedade civil e o regime militar, que possibilitou, à época, a transição para o regime democrático", ressaltando que o objetivo da lei era "que ambos os lados seriam beneficiados com a anistia, evitando-se, inclusive, qualquer espécie de revanchismo no novo governo".

Para a AGU, "a mens legislatoris da época não passou despercebida pelos diversos setores da sociedade"; para comprová-lo, transcreveu longos trechos do já citado parecer de Sepúlveda Pertence, aprovado pelo Conselho Federal da $\mathrm{OAB}^{466}$, e também manifestação do Instituto dos Advogados Brasileiros, de 15 de agosto de 1979, dirigida ao Senado Federal, com base em parecer do advogado

\footnotetext{
${ }^{465}$ No resumo que faremos dos pareceres, bem como, a seguir, dos votos proferidos, iremos nos ater aos argumentos relativos ao sentido original de "crimes conexos", tal como originalmente pretendido pelos legisladores de 1979 e 1985 - ponto que foi decisivo para a decisão proferida pelo STF. Houve, sem dúvida, debate sobre inúmeros outros pontos de suma importância (como as hipóteses de cabimento da ADPF, a preservação da segurança jurídica, a ocorrência de prescrição e a influência dos tratados internacionais), que não tocam diretamente, no entanto, ao tema objeto desta tese.

${ }^{466}$ Disse a AGU: “....o argüente aguardou mais de trinta anos de vigência da Lei de Anistia(...) e vinte anos de vigência da Constituição Federal para mudar a interpretação e, tardiamente, apresentar uma extemporânea irresignação . (...) Agora, o Conselho da OAB volta-se contra sua própria opinião, essencial àquela época para a formação da mentalidade que permitiu entender que todos os sujeitos que eventualmente tivessem praticado quaisquer ilícitos fossem beneficiários da anistia."
} 
Sérgio Tostes, no qual a delicada questão dos crimes conexos era enfrentada sem subterfúgios:

“... é fora de dúvida que o parágrafo $1^{\circ}$. do citado artigo $1^{\circ}$. pode dar margem a se excluir do campo da apreciação judicial aqueles que podem ser qualificados como 'torturadores'. A idéia do crime conexo certamente aproveitará aqueles que extravasaram na competência legal e infligiram sofrimentos morais e físicos. Por mais que repugne à sensibilidade humana (....) por uma questão de coerência, por se considerar que a idéia de anistia implica num esquecimento total, é de se concordar com a menção expressa do citado parágrafo $1^{\circ}$. O que visa a anistia é esquecer o passado e se viver o presente com vistas ao futuro. Desta forma, se a anistia deve ser como o exige o presente momento histórico, ampla, geral e irrestrita, deve também abranger todos àqueles que de uma forma ou de outra estiveram envolvidos no processo de exacerbação de ânimos". 467

A AGU também trouxe à colação antigos julgados do Superior Tribunal Militar, reconhecendo a "amplíssima abrangência" da anistia ${ }^{468}$, e do Superior Tribunal de Justiça, reconhecendo que ela atingira "vencidos e vencedores" 469

Especificamente em relação ao significado da conexão prevista pela Lei de Anistia, concluiu a AGU que ele deveria ser entendido, apenas para os efeitos dessa norma, com "a abrangência que se quis dar à medida", enfatizando que conferir-lhe caráter restritivo seria "dissidente da pretensão do legislador" (destaques nossos).

Por sua vez, o parecer da Procuradoria-Geral da República afirmou que não seria adequado fazer uma leitura "atemporal" da lei, e incursionou

\footnotetext{
${ }^{467}$ Os destaques são nossos. Mantivemos a redação conforme consta do parecer da AGU.

${ }^{468}$ Acórdão n. 1986.01.005751-7-MG, rel. min. José Luiz Clerot, j. 7.5.87.

${ }^{469}$ Recurso Especial n. 23757-DF, rel. min. Peçanha Martins, j. 14.12.1992. O mesmo ministro Peçanha Martins, ao relatar o MS n. 756, reiterou que "a anistia decretada visou apagar fatos cometidos por vencidos e vencedores" (Primeira Seção, m.v., j. 9.4.1991).
} 
pelo contexto histórico em que editada a norma, qualificando-o como "absolutamente decisivo para sua adequada interpretação", uma vez que a anistia "resultou de um longo debate nacional, com a participação de diversos setores da sociedade civil, a fim de viabilizar a transição entre o regime autoritário militar e o regime democrático atual".

Reconheceu ainda o Ministério Público a existência, à época, de "legítimas negociações" entre o governo e organizações da assim chamada "sociedade civil" , inclusive a própria Ordem dos Advogados do Brasil, considerada como "ator fundamental no sentido de mediar a integração entre as forças políticas e sociais para viabilizar a transição do regime militar para a democracia", sendo muitas de suas sugestões acatadas pelo Congresso Nacional, a partir do parecer de Sepúlveda Pertence, do qual se fez longa transcrição. ${ }^{470}$

A Procuradoria Geral da República considerou relevante trazer o testemunho atual do ministro Pertence, em entrevista concedida em janeiro de 2010 ao jornal eletrônico Carta Maior, do qual destacamos, pela sua absoluta pertinência com a linha argumentativa desta tese, o seguinte trecho:

"No projeto, havia um ponto inegociável pelo Governo: o $\S 1^{\circ}$. do art. $1^{\circ}$, que, definindo, com amplitude heterodoxa, o que se considerariam crimes conexos aos crimes políticos, tinha o sentido indisfarçável de fazer compreender, no alcance da anistia, os delitos de qualquer natureza cometidos nos 'porões do regime', como então se dizia, pelos agentes civis e militares da repressão

Meu parecer reconheceu abertamente que esse era o significado inequívoco do dispositivo. (...)

É expressivo recordar que, no curso de todo o processo legislativo - que constituiu um marco incomum de intenso debate parlamentar sobre um projeto dos governos militares -, nem uma voz tenha se levantado para por em dúvida a interpretação de que o $\operatorname{art.} 1^{\circ}$., $\S 1^{\circ}$, se aprovado, como foi, implicava a anistia da

\footnotetext{
${ }^{470}$ Itens ns. 84-91 do parecer da PGR.
} 
tortura praticada e dos assassínios perpetrados por servidores públicos, sob o manto da imunidade de fato do regime de arbítrio.

Não superei a impressão inicial de que a maestria do autor não logrou livrar a tese do pecado do anacronismo: ela pretende reler, à luz da Constituição de hoje, que fez da tortura crime 'insusceptível de graça e anistia', e de convenções internacionais que ditam a sua imprescritibilidade, a inequívoca interpretação de uma lei de 1979, editada sob a égide da Carta de $1969(\ldots) ., 471$

Além do inegável relevo emprestado ao testemunho de um partícipe da elaboração da norma, para assim resgatar a intenção original com que redigido o preceito - que, como dissemos, foi uma constante ao longo de todo o julgamento -, cabe aqui anotar que a referência feita pelo eminente ministro ao "pecado do anacronismo" seria entusiasticamente aplaudida pelo mais ortodoxo dos originalistas...

Com vistas a comprovar o real envolvimento da sociedade na discussão do projeto, o parecer foi buscar a primeira manifestação pública a respeito do tema (do Movimento Feminino pela Anistia, liderado por Therezinha Zerbini, em $1975^{472}$ ), e transcreveu trecho de discurso feito no Congresso Nacional pelo então Senador Franco Montoro, em que foi lido um manifesto de artistas "pela anistia ampla, geral e irrestrita", do qual constava:

\footnotetext{
"Não podemos admitir, sobretudo, que quando se pretende uma conciliação Nacional sejam anistiados uns e marginalizados outros (...) No entanto este não é o momento em que
}

\footnotetext{
${ }^{471}$ Itens 92 e 110 do parecer da PGR; texto também disponível em www.cartamaior.com.br, 18.1.2010.

${ }^{472}$ Confirma-o Elio Gaspari: “....a anistia ganhava corpo desde que Therezinha Zerbine organizou os primeiros núcleos do Movimento Feminino pela Anistia, em março de 1975" (A Ditadura Encurralada, Cia.das Letras, 2004, p. 450). As diferentes grafias foram mantidas tal como nos originais citados.
} 
se devam reascender divergências. E nem mesmo perguntar - por mais evidente que seja a resposta - quem atirou a primeira pedra., ${ }^{, 73}$

Salientou o Procurador-Geral da República que aceitar a nova interpretação proposta pela $\mathrm{OAB}$ "para desconstituir a anistia como concebida no final da década de 70 significaria romper com o compromisso feito naquele contexto histórico" (destaques nossos).

\subsubsection{O julgamento}

O extenso e bem elaborado voto do relator, ministro Eros Grau, abordou inúmeros pontos em sua fundamentação; aqui vamos nos ater, naturalmente, àqueles que dizem respeito ao nosso tema.

A partir do item 21 de seu voto, o ministro Eros Grau reconstituiu demoradamente o contexto histórico em que editada a Lei de Anistia, para assim justificar a interpretação adequada de seus termos. No item 22, transcreveu depoimento de Dalmo de Abreu Dallari, na qualidade de partícipe do processo que levou à edição da lei:

"Nós sabíamos que seria inevitável aceitar limitações e admitir que criminosos participantes do governo ou protegidos por ele escapassem da punição que mereciam por justiça, mas considerávamos conveniente aceitar essa distorção, pelo benefício que resultaria aos perseguidos e às suas famílias e pela perspectiva de que teríamos a nosso lado companheiros de indiscutível vocação democrática e amadurecidos pela experiência" (destaques nossos).

\footnotetext{
${ }^{473}$ Foi mantida a grafia e pontuação constantes da transcrição feita no parecer da PGR. A relevância desta citação deve-se ao fato de serem simultaneamente invocadas, como relevantes para a interpretação do entendimento original da norma, o pronunciamento de um destacado parlamentar da época e um manifesto da "sociedade civil". A publicação desse discurso no Diário do Congresso Nacional ocorreu - e cremos que não foi por acaso - na muito simbólica data de 11 de agosto de 1979.
} 
E, presente essa "aceitação" pelas forças políticas de oposição ao regime é que se chegou à fórmula adotada pela lei, concedendo perdão aos crimes políticos e aos que fossem a eles conexos.

O ministro Grau, então, explica que esse conceito não foi utilizado no sentido técnico, mas com intenção inteiramente diversa:

"28. Essa expressão, crimes conexos a crimes políticos, conota sentido a ser sindicado no momento histórico da sanção da lei. Sempre há de ter sido assim. A chamada Lei de anistia diz com uma conexão sui generis, própria ao momento histórico da transição para a democracia. Tenho que a expressão ignora, no contexto da Lei n. $6.683 / 79$, o sentido ou os sentidos correntes, na doutrina, da chamada conexão criminal. Refere o que 'se procurou', segundo a inicial, vale dizer, estender a anistia criminal de natureza política aos agentes do Estado encarregados da repressão. (...)

29. A argüente tem razão: o legislador procurou estender a conexão aos crimes praticados pelos agentes do Estado contra os que lutavam contra o Estado de exceção. Daí o caráter bilateral da anistia, ampla e geral.”

E o relator ainda transcreveu trecho de entrevista recente do ministro Sepúlveda Pertence, em que reafirmava o parecer que elaborara em 1979, reconhecendo que a menção a crimes conexos "tinha o sentido indisfarçável de fazer compreender, no alcance da anistia, os delitos de qualquer natureza cometidos nos 'porões do regime', como então se dizia'.

Ou seja: para o relator, o sentido de crimes conexos não podia ser atualizado com os critérios do momento presente. Para se fazer justiça, e dar adequada solução à controvérsia constitucional, esse sentido havia de ser buscado no passado, 
na intenção do legislador (original intent) e na compreensão dessa norma pelos contemporâneos (original understanding).

E para chegar a esse resultado, buscaram-se depoimentos da época e, quando possível, sua ratificação no presente, pelos próprios personagens daquela quadra da história.

Essa mesma abordagem esteve presente em todos os votos que compuseram a maioria. ${ }^{474}$

A ministra Cármen Lúcia, no item n. 13 de seu voto, bem ressaltou que o enfoque interpretativo a ser adotado era, em verdade, a questão central do julgamento:

“A opção inicial do intérprete (....) haverá de ser entre a adoção de elementos de inteligência da norma segundo os parâmetros atuais, incluídos os princípios constitucionais vigentes, desapegando-os de seu momento originário, de seu surgimento, ou, diversamente, acolher como elemento determinante para a sua interpretação o quadro fático-histórico no qual veio a ser criada e a finalidade nela patenteada" (destaques nossos).

E embora fizesse restrições à interpretação histórica, a ministra reconhecia que "para o caso específico, difícil seria desconhecer o que se vivia e para o que se deu a elaboração da Lei agora em questão", optando por reafirmar o entendimento consolidado quanto ao alcance da lei, à época de sua promulgação. Citou, inclusive, a recomendação de Henry Campbell Black, alertando para a conveniência de interpretar as leis "em consonância com seu espírito e razão", atendida a "plena intenção legislativa". ${ }^{475}$ Também incursionou, como os demais votos vencedores, sobre o entendimento original da Lei de Anistia e sua natureza pactuada,

\footnotetext{
${ }^{474}$ Ficaram vencidos os ministros Ayres Britto e Ricardo Lewandowski.

${ }^{475}$ Handbook on the Construction and Interpretation of the Laws, p. 48.
} 
resultante de "pressão social, em especial dos principais setores atuantes da sociedade civil", após "amplo debate" e "manifestações expressas e específicas das principais entidades e personalidades então atores do processo da chamada abertura”.

E já nos fundamentos finais de sua manifestação (item n. 17), a ministra Cármen Lúcia reiterou que seria inadequado

“tomar-se a interpretação da Lei n. 6.683/79 decotada do momento e das circunstâncias históricas (...) Não há como julgar o passado com os olhos apenas de hoje, desconhecendo o que se fez, se ajustou e se comprometeu".

O ministro Gilmar Mendes chamou a atenção, no item 3.2 de seu voto, para os "compromissos constitucionais" presentes na época da redemocratização, e a própria "natureza pactual da Carta Constitucional de 1988", que já se encontrava presente no processo de anistia, definindo sua amplitude (item 3.3). Fez longa transcrição do parecer de Sepúlveda Pertence, a quem chamou de "testemunha privilegiada" daquele momento histórico. Transcreveu, com o mesmo objetivo, trecho de parecer elaborado à mesma época pelo advogado Sérgio Tostes, expressando a posição oficial do Instituto dos Advogados Brasileiros, em que se reconhecia o caráter irrestrito da anistia, que "não deve ter limites", porque "ato de conciliação da nação consigo mesma". Recorreu ainda a discurso pronunciado em 17 de março de 1981 (portanto, já vigente a lei), pelo então Senador Paulo Brossard, líder da oposição, em que era ironicamente afirmado: "Estejam tranqüilos os torturadores. O caráter bilateral da anistia os beneficiou: estão eles a salvo da lei penal pelos crimes que tenham cometido".

E, ao final do item 3.4 de seu voto, concluiu o ministro Gilmar

Mendes que

“... a EC n. 26/85 incorporou a anistia como um dos fundamentos da nova ordem constitucional que se construía à época, fato que torna praticamente impensável qualquer modificação de seus 
contornos originais que não repercuta nas próprias bases de nossa Constituição e, portanto, de toda a vida político-institucional pós1988" (o destaque é nosso).

A ministra Ellen Gracie, aderindo integralmente ao voto do relator, também emprestou relevo às circunstâncias históricas da anistia para a compreensão do exato sentido da lei. Após invocar o parecer de Sepúlveda Pertence (a quem apropriadamente se referiu como "presente a este julgamento como se ainda participasse da bancada"), e também o mencionado depoimento de Dalmo Dallari, como outra testemunha autorizada daquele processo de negociação política, concluiu a ministra que não se devia desvirtuar a história "para que assuma contornos que nos pareçam mais palatáveis".

O ministro Marco Aurélio, ao acompanhar o relator, mencionou que era "preciso apreciar a edição da Lei de Anistia, não considerado o contexto atual, mas o da época".

O ministro Celso de Mello, por sua vez, após criticar os regimes de exceção e destacar a intensa reprovabilidade da tortura, enveredou pela análise histórica, citando até mesmo a Exposição de Motivos da Emenda Constitucional n. 11/78, que "assinalou o início do processo de redemocratização", para a seguir reconhecer - transcrevendo parecer da Procuradoria-Geral da República, que a anistia resultara "de um longo debate nacional, com a participação de diversos setores da sociedade civil, a fim de viabilizar a transição entre o regime autoritário militar e o regime democrático atual". E era precisamente por essa razão, prosseguiu o ministro, que a anista havia sido "bilateral" e "recíproca", eis que "o objetivo da proposta submetida a amplo debate nacional era, sem qualquer dúvida, o de beneficiar tanto os adversários do regime castrense quanto os agentes incumbidos da repressão". Como prova desse amplo entendimento, fez a seguir extensa citação do já referido parecer do ministro Sepúlveda Pertence. 
É ainda no voto do ministro Celso de Mello que vemos a mais demorada reflexão sobre uma fonte interpretativa bastante valorizada pelo originalismo: o exame dos debates parlamentares.

Muito embora fazendo a ressalva de considerar "relativo" e "sem valor preponderante" esse exame - o ministro atribuiu-lhe a dignidade de "método hermenêutico", constituindo

"expressivo elemento de útil indagação das circunstâncias que motivaram a elaboração de determinado texto normativo (...) permitindo o conhecimento das razões que levaram o legislador a acolher ou a rejeitar as propostas submetidas ao exame do Poder Legislativo".

Bem por isso, reconhecia "a importância, para fins de exegese, da análise dos debates parlamentares, cujo conhecimento poderá orientar o julgador no processo de interpretação jurídica".

Passou então a fazer longa citação de discurso do Senador Paulo Brossard (também referido, como visto, no voto do ministro Gilmar Mendes), em ordem a comprovar a intenção do legislador ao editar aquela lei.

E, a despeito das ressalvas que fizera, o ministro Celso de Mello ainda outra vez enveredou pela análise da intenção do legislador - desta feita, do constituinte, quase uma década depois da Lei de Anistia - trazendo argumento inteiramente novo ao debate:

“Há, ainda, outra observação a fazer. Refirome ao fato de que a nova Constituição do Brasil, promulgada em 1988, poderia, até mesmo, precisamente porque elaborada por órgão investido de funções constituintes primárias (ou originárias), suprimir a eficácia jurídica que se irradiou da Lei da Anistia de 1979, ordenando, ela própria, a restauração do status quo ante.

Sucede, no entanto, que tal não se verificou, muito embora esse tema pudesse estar presente na intenção e na deliberação da Assembléia Nacional Constituinte, a atestar, desse 
modo, muito claramente, que não se registrou, nesse específico tema, qualquer omissão do órgão formulador da nova Constituição brasileira, configurando, antes, esse comportamento dos constituintes, uma clássica hipótese de lacuna consciente ou voluntária, que traduz, quando ocorrente, a disposição inequívoca de não tratar da matéria". ${ }^{476}$

Finalizando o julgamento, o presidente do Tribunal, ministro Cezar Peluso, igualmente acolheu o testemunho de Sepúlveda Pertence quanto para definir "o significado inequívoco da lei”, reconhecido na própria petição inicial, também reconhecendo que "a lei nasceu de um acordo costurado por quem tinha legitimidade social e política para, naquele momento histórico, celebrar um pacto nacional".

\subsubsection{O significado da decisão}

Em suma, e reiterando o que foi dito ao início deste tópico: pela primeira vez, e por ampla maioria, formada por sete ministros, com apenas dois votos vencidos, o Pretório Excelso dirimiu uma controvérsia constitucional mediante análise da intenção do legislador e do sentido com que a sociedade entendeu a norma aplicável, à época de sua edição. É certo que outras considerações também foram feitas, nesse longo e delicado julgamento; no entanto, é inegável que o ponto central da controvérsia foi dirimido segundo padrões originalistas.

E esse tipo de abordagem - é importante salientar - foi indispensável para se chegar a uma solução justa e adequada da controvérsia, prestigiando o valor fundamental da segurança jurídica.

Com as devidas vênias, não concordamos com a apreciação deste caso feita por professor Luis Roberto Barroso, para quem o Supremo Tribunal Federal

\footnotetext{
${ }^{476}$ Omitimos da transcrição de trechos desse voto, para facilitar a leitura, os destaques empregados pelo ilustre ministro.
} 
optou pela paz, em detrimento da justiça. ${ }^{477}$, O resultado aqui alcançado contemplou igualmente os dois valores, que se complementam. Não nos parece possível alcançar a paz sem realizar a verdadeira justiça.

\subsection{Uma questão pendente: o conceito constitucional de quilombo}

\subsubsection{Colocação do problema}

Estabelece o art. 68 do Ato das Disposições Constitucionais Transitórias: "Aos remanescentes das comunidades dos quilombos que estejam ocupando suas terras é reconhecida a propriedade definitiva, devendo o Estado emitirlhes os títulos respectivos".

Relevante polêmica adveio da publicação, quinze anos depois, do Decreto n. 4.887, de 21 de novembro de 2003, que fixa "procedimento para identificação, reconhecimento, delimitação, demarcação e titulação das terras ocupadas por remanescentes dos quilombos". Inúmeras questões foram então suscitadas a respeito da correta interpretação da norma constitucional: se ela alcança somente bens públicos ou também particulares (uma vez que estes já estariam sujeitos a usucapião); se ela autoriza desapropriações e respectivos gastos com indenizações; se é possível (ou necessária) sua regulamentação diretamente por decreto. Já houve, inclusive, decisão de Tribunal Federal que questionou sua constitucionalidade, por aparente violação do direito de propriedade. ${ }^{478}$

\footnotetext{
${ }^{477}$ Citando textualmente o ilustre constitucionalista: "Na vida existem missões de justiça e missões de paz. O STF optou pela segunda." (Prudências, ousadias e mudanças necessárias no STF. Consultor Jurídico, 28.12.2010).

478 TRF-4 ${ }^{\text {a }}$. Região, Agravo de Instrumento n. 2004.04.01.057365-8/RS, rel. Des. Fed. Carlos Eduardo Thompson Flores Lenz (j. 8.8.2005).
} 
O ponto relevante para este trabalho diz respeito à tentativa de modificação do conceito de quilombo, deturpando aquele originalmente previsto pelo constituinte.

De fato, o decreto estabelece o critério de "auto-atribuição" para identificar os remanescentes de quilombos (art. $2^{\circ}$., caput e $\S 1^{\circ}$.); de outra parte, pretende definir que as "terras" mencionadas pela Constituição sejam "as utilizadas para garantia de sua reprodução física, social, econômica e cultural” (art. $2^{\circ}$., §2º.), também segundo "critérios de territorialidade" fornecidos pelos próprios interessados $\left(\operatorname{art.} 2^{\circ} ., \S 3^{\circ}\right.$.).

Sem entrar no mérito da proposta - que poderia, se for o caso, ser viabilizada por outros meios - observamos ter havido, inegavelmente, uma notável ampliação do significado original do texto constitucional.

Ao tempo em que promulgada a Constituição, o comando que emergia do art. 68 do ADCT era bastante claro: referia-se aos antigos quilombos, que o Dicionário Houaiss assim define:

“1. acampamento fortificado dos jagas, designação atribuída aos povos que invadiram o Congo e Angola em fins do século XVI; 2. local escondido, geralmente no mato, , onde se abrigavam escravos fugidos; 3. povoação fortificada de negros fugidos do cativeiro, dotada de divisões e organização interna (onde tb. se acoitavam índios e eventualmente brancos socialmente desprivilegiados)". ${ }^{479}$

Seria útil lembrar aqui a antiga regra de interpretação constitucional formulada por Henry Campbell Black: "As palavras empregadas numa constituição

${ }^{479}$ Dicionário Houaiss da Língua Portuguesa, $1^{\mathrm{a}}$. ed., 2001, p. 2359. As palavras abreviadas foram aqui escritas por extenso. Note-se que cada uma das definições é antecedida pela indicação "HIST B" - História do Brasil, o que tem relevo para a argumentação que segue. 
devem ser tomadas em seu sentido natural e popular, exceto quando sejam termos técnicos jurídicos". Ou ainda: "É uma regra geral que as palavras de uma constituição devem ser entendidas no sentido em que são popularmente empregadas (...) em seu sentido óbvio, claro e comum". ${ }^{480}$

Joseph Story, com apoio em Blackstone, também aponta que, na interpretação de textos legais, "as palavras devem ser geralmente entendidas em seu significado usual e mais conhecido". 481

Esse sentido histórico bem delimitado é exposto por Uadi Lammêgo Bulos, quando explica que "os quilombos, muito mais do que centros de convivência de comunidades escravagistas desenvolvidas no Brasil, foram marcas da luta pela liberdade". ${ }^{482}$

O preceito constitucional em foco tem o claro propósito de garantir aos remanescentes de antigas comunidades quilombolas a propriedade das terras que estivessem efetivamente ocupando em $1988 .^{483}$

É a leitura que faz Ives Gandra da Silva Martins, identificando a incidência do dispositivo constitucional em situações de fato consolidadas, com base na realidade histórica:

"Não se sabia à época que terras ainda estavam sendo ocupadas por remanescentes dos quilombos. O certo é que as terras que possuíam na promulgação da Constituição passaram a ser de sua propriedade definitiva, devendo o Estado apenas transformar a posse em propriedade, transferindo aos remanescentes os títulos nesse sentido" ${ }^{, 44}$

\footnotetext{
${ }^{480}$ Henry Campbell Black, Handbook on the Construction and the Interpretation of the Laws, 1896, § 16, p. 25.

${ }^{481}$ Joseph Story, Commentaries on the Constitution of the United States, 1833, vol. I, § 400, p. 384.

${ }^{482}$ Uadi Lammêgo Bulos, Curso de Direito Constitucional, 2007, p. 1309 (o destaque é nosso).

${ }^{483}$ Foi esse, aliás, o entendimento inicialmente adotado pela Presidência da República, ao editar o Decreto n. 3.912, de 10.9.2001, que previa, em seu art. $1^{\circ}$., parágrafo único, que "somente pode ser reconhecida a propriedade sobre terras que: I - eram ocupadas por quilombos em 1888; e II estavam ocupadas por remanescentes das comunidades dos quilombos em 5 de outubro de 1988". Este decreto foi revogado pelo de n. 4.887/2003.

${ }^{484}$ Ives Gandra da Silva Martins e Celso Ribeiro Bastos, Comentários à Constituição do Brasil, 2002, v. 9, p. 490; os destaques são nossos.
} 
Pinto Ferreira também assinala que o dispositivo beneficia "as pessoas que estejam em tais terras" ${ }^{\text {"485 }}$, do que não discrepa Alexandre Nester:

"O dispositivo cuida, isto sim, da situação específica dos remanescentes das comunidades de quilombos que ocupam terras, aos quais se reconhece a propriedade, cabendo ao Estado emitir o respectivo título que consolide uma posse atual (em 1988). (...)

Portanto, a interpretação (sistemática) possível para a regra do art. 68 do ADCT consiste na concessão de um benefício específico àqueles remanescentes de comunidades de quilombos que estejam ocupando terras de propriedade do Poder Público". ${ }^{486}$

Este também parece ser o entendimento de José Afonso da Silva, para quem o dispositivo "consolida, em definitivo, a propriedade das terras ocupadas pelos remanescentes das comunidades dos quilombos, sem qualquer outra formalidade senão a simples constatação da ocupação". ${ }^{487}$

Cláudio Teixeira da Silva, em cuidadosa análise, enfatiza:

"O vocábulo remanescentes tem a acepção de coisas ou pessoas que ficam, restam ou subsistem. Já a palavra quilombo tem o significado de comunidade existente na época escravagista formada por escravos fugidos. Pode-se dizer, então, que remanescentes das comunidades dos quilombos são os moradores das comunidades formadas por escravos fugidos ao tempo da escravidão, e os seus descendentes, que permaneceram, ficaram, subsistiram, após a promulgação da Lei Áurea, nas terras em que estavam localizados aqueles grupamentos.

\footnotetext{
${ }^{485}$ Pinto Ferreira, Comentários à Constituição Brasileira, v. 7, 2007, p. 653.

${ }^{486} \mathrm{O}$ art. 68 do ADCT e a titulação de terras a remanescentes de comunidades de quilombos, 2008 , disponível no endereço eletrônico www.justen.com.br.

${ }^{487}$ Comentário Contextual à Constituição, 2005, p. 931. Os destaques, que são nossos, sinalizam a referência a uma situação preexistente, que se consolida com a edição da norma constitucional.
} 
No caso do art. 68 do ADCT, entretanto, a expressão remanescentes das comunidades dos quilombos não pode ser considerada de forma isolada, sob pena de se conferir o direito previsto no artigo a quem não faz jus a ele. Observa-se que o dispositivo dirige-se apenas àqueles remanescentes 'que estejam ocupando suas terras' no momento da promulgação da Constituição de 1988. Foram excluídos, portanto, os antigos moradores das referidas comunidades e os seus descendentes que, apesar de terem vivido nas terras dos quilombos após o ano de 1888, não mais as ocupavam em 05.10.1988.

Feitas essas considerações, que defluem do texto constitucional, chega-se à conclusão que o constituinte de 1988 visou a beneficiar tão-somente os moradores dos quilombos e os seus descendentes que viviam nas terras sobre as quais estavam localizadas aquelas comunidades em 1888, e que continuaram a ocupá-las após o citado ano até 05.10.1988". 488

Não poderia ser outro o entendimento de um artigo colocado nas Disposições Transitórias da Constituição, isto é, um comando temporário, destinado a desaparecer assim que alcançados seus efeitos. ${ }^{489}$

Tão limitado é o alcance do art. 68 do ADCT, que Manoel Gonçalves Ferreira Filho chega a considerá-lo "inútil", porque a posse centenária de terras de antigos quilombos de há muito teria ensejado a aquisição da propriedade por usucapião; somente restaria a aplicação a terras públicas, o que contradiz a regra geral de sua inalienabilidade, duas vezes enunciada na parte permanente da Constituição (arts. 191, par. ún., e 183, § $3^{\circ}$.). ${ }^{490}$

\footnotetext{
${ }^{488}$ Cláudio Teixeira da Silva, O usucapião singular disciplinado no art. 68 do Ato das Disposições Constitucionais Transitórias. Revista de Direito Privado, v. 11, 2002, pp. 79-83 (os destaques são do texto original). Em uma das notas de rodapé ao trecho transcrito (outras foram suprimidas desta citação), salienta-se que o artigo em comento "também não contemplou os antigos moradores de quilombos extintos no período anterior à Lei Áurea. Certamente, não podem ser essas pessoas ser consideradas remanescentes, porquanto já não mais ocupavam, antes daquele evento, as terras cuja propriedade foi reconhecida pela Constituição".

${ }^{489}$ Nesse sentido: Uadi Lammêgo Bulos, Curso, p. 1357; STF, ADI 644-MC, rel. Min. Sepúlveda Pertence, DJU 21.2.1992).

${ }^{490}$ Manoel Gonçalves Ferreira Filho, Comentários à Constituição Brasileira de 1988, 1995, vol. 4., p. 182.
} 
A gênese desse artigo, nos anais da Assembléia Constituinte, confirma integralmente a análise feita pelos autores citados.

O primeiro antecedente do art. 68 do ADCT no processo constituinte surgiu com a Sugestão de Norma Constitucional n. 2886, enviada pelo Centro de Estudos Afro-Brasileiros, nos seguintes termos: "Será garantido o título de propriedade da terra às comunidades negras remanescentes de quilombos, quer no meio urbano ou rural". 491

Dois registros merece essa proposta: o reconhecimento da propriedade, nesse caso, como um direito coletivo e não individual (“às comunidades negras"), e a expressa menção à possibilidade de serem alcançados imóveis urbanos. As duas idéias não mais subsistiram, em nenhuma das fases da elaboração constitucional.

Poucos dias depois, registrava-se a Sugestão n. 9.015, da constituinte Benedita da Silva, de seguinte teor: "O Estado priorizará na [sic] distribuição de títulos de propriedade de terra, como medida compensatória, o pleito da comunidade afro-brasileira". ${ }^{492}$ Tal proposta foi prontamente descartada, mesmo no âmbito da Subcomissão dos Negros, Populações Indígenas, Deficientes e Minorias (Subcomissão Temática VIIc), o que desde logo deixa claro que o contituinte nunca teve em mira, no citado dispositivo, estabelecer um critério preferencial para reforma agrária. A referida Subcomissão, em sua 16 ${ }^{\text {a }}$ Reunião Ordinária, realizada em 25 de maio de 1987, aprovou por unanimidade a proposta do relator Alceni Guerra, nela incluída o art. $6^{\circ}$. "O Estado garantirá o título de propriedade definitiva das terras ocupadas pelas comunidades negras remanescentes dos Quilombos."

\footnotetext{
${ }^{491}$ Diário da Assembléia Nacional Constituinte, edição de 9.5.1987, p. 531 (item IX, n. 2)

${ }^{492}$ Diário da Assembléia Nacional Constituinte, edição de 29.5.1987, pp. 24-25

${ }^{493}$ Votaram favoravelmente à proposta os constituintes Ivo Lech (presidente da subcomissão), Alceni Guerra (relator), Doreto Campanari, Benedita da Silva, Jacy Scanagatta, José Carlos Sabóia, nelson Seixas, Ruy Nedel, Salatiel Carvalho, Osmir Lima e Sandra Cavalcanti. Nenhum destaque foi apresentado em relação ao citado art. $6^{\circ}$ - Diário da Assembléia Nacional Constituinte, ed. 24.7.1987, pp.150-151.
} 
$\mathrm{Na}$ fase seguinte, de elaboração de anteprojetos parciais, a Comissão da Ordem Social associou a questão dos quilombos à proteção do patrimônio histórico e cultural, aprovando a seguinte redação para o dispositivo:

“Art. 107 - Fica declarada a propriedade definitiva das terras ocupadas pelas comunidades negras remanescentes dos quilombos, devendo o Estado emitir-lhes os títulos respectivos. Ficam tombadas essas terras bem como todos os documentos referentes à história dos quilombos no Brasil."

$\mathrm{Na}$ fase de elaboração de um primeiro Anteprojeto geral, a cargo da Comissão de Sistematização, o dispositivo aprovado na Comissão da Ordem Social teve sua redação mantida, sendo porém deslocado para as Disposições Transitórias, onde foi renumerado como art. 497. E assim também ficou no primeiro Projeto de Constituição, de agosto de 1987, desta feita como art. 490, e no primeiro Substitutivo do relator Bernardo Cabral, como o art. 38 das Disposições Transitórias. ${ }^{494}$

No chamado "Projeto B", ao final do primeiro turno de votação na Assembléia, o dispositivo foi desmembrado: a primeira parte foi mantida nas Disposições Transitórias, enquanto a segunda parte (relativa ao tombamento dos sítios históricos, foi transferida para a parte permanente, como $\S 5^{\circ}$. do (então) art. 219. Esse projeto mereceu a aprovação de 355 constituintes e apenas 9 votos contrários, além de 15 abstenções. $^{495}$

Este ponto é de fundamental importância para a compreensão da efetiva vontade do constituinte, pois bem demonstra que este soube diferenciar as matérias: a promoção da cultura africana deveria ser permanente, enquanto que o reconhecimento da propriedade dos remanescentes dos quilombos seria episódica.

${ }^{494}$ Houve apresentação de emendas em Plenário, propondo a supressão do dispositivo (como exemplos, a Emenda 7170, do constituinte Eliel Rodrigues, e a Emenda 18901, do constituinte Acival Gomes). A Comissão de Sistematização, porém, acolheu as manifestações do relator pela manutenção do texto.

495 Diário da Assembléia Nacional Constituinte, ed. de 22/06/1988, pp. 11.499-11.502. 
Saliente-se que, durante os debates em Plenário, várias propostas foram apresentadas no sentido da supressão pura e simples do dispositivo. Dentre elas, destacamos a Emenda n. 61, apresentada pelo constituinte Eliel Rodigues, rejeitada com base no parecer do relator Bernardo Cabral, do qual se extrai o seguinte trecho:

“Alega o Parlamentar que a emissão dos títulos de propriedade pelo Estado criará "verdadeiros guetos" e a prática do "apartheid" no Brasil. A despeito da preocupação do Constituinte quanto à possibilidade de segregação social e desigualdade dos direitos civis, a nossa posição não enxerga esses males, porém apenas objetiva legitimar uma situação de fato e de direito, isto é, a posse e o domínio das comunidades negras sobre áreas nas quais vivem, realizam a sua história durante mais de um século, continuadamente, apesar dos atentados e crimes de toda ordem praticados contra as suas culturas, liberdades e direitos. Os guetos são fenômenos sociológicos, antropológicos, filhos da História do Homem e da Civilização, e não obras de escrituras públicas que apenas oficializam o domínio pleno, justo e continuado de um povo exilado de sua própria pátria, pela violência e a injustiça" (destaques nossos).

Vê-se que o enfático parecer do relator, que serviu de base à aprovação final do dispositivo pela Assembléia Constituinte, referia-se expressamente ao "domínio pleno, justo e continuado", “durante mais de um século". Uma vez que o texto beneficia "os remanescentes ... que estejam ocupando as suas terras", conclui-se que a interpretação correta foi a dos juristas anteriormente citados, que escreveram seus comentários logo após a promulgação da Carta, e bem assim a que foi adotada pelo próprio Poder Executivo, quando editou o Decreto n. 3.912/2001. 
Do até aqui exposto, conclui-se que o conceito constitucional de quilombo não se aparta da noção corrente do termo, de inegável apelo histórico. Compreensão que é também favorecida pelo fato de, em outro dispositivo ( $\mathrm{CF}$, art. $216, \S 5^{\circ}$.), haver o constituinte associado os quilombos à idéia de "reminiscência histórica", para fins de tombamento e proteção do patrimônio cultural.

Na Ação Direta de Inconstitucionalidade n. 3239, ajuizada pelo (então denominado) Partido da Frente Liberal e ainda pendente de julgamento, alega-se - dentre outros fundamentos - que o Decreto n. 4.887/2003 permite um indevido alargamento do conceito de quilombo, atingindo imóveis privados, de há muito objeto de regular titulação dominial, assim como outros, recentemente ocupados e até em áreas urbanas, sem a mais remota relação com os antigos quilombos.

Afirma-se, na petição inicial dessa ação $\operatorname{direta}^{496}$, que admitir-se uma simples manifestação de vontade do interessado como fator preponderante para definir "a rara característica de remanescente das comunidades quilombolas" (pois a prova em contrário será ônus de eventual contestante), "importa radical subversão da lógica constitucional”, pois seria indispensável, de acordo com a letra e o espírito do art. 68 do ADCT, comprovar (e não apenas alegar) a remanescência física e histórica das comunidades, e não simples descendência individual de antigos escravos. Nesse sentido é citada a lição de Cretella Júnior - escrita, por sinal, logo após a promulgação da Constituição: “....se determinado habitante de comunidade atual provar que é remanescente de quilombola da mesma comunidade (....) o Estado lhe emitirá título de domínio, em razão do esforço heróico em defesa das terras por ele ocupada e cultivada". 497

\footnotetext{
${ }^{496}$ Consultada no endereço eletrônico do Supremo Tribunal Federal (www.stf.jus), em 31.10.2010.

${ }^{497}$ Comentários à Constituição Brasileira de 1988, 2ª . ed., vol. 9, Forense Universitária, 1999, , pp. 4988-4989.
} 
A edição do aludido decreto enseja o fenômeno da releitura de um dispositivo que, à época em que editado, tinha sentido bem diverso do que hoje nele se pretende enxergar.

Como diz Denis Rosenfield, ocorre uma “interpretação enviesada da Constituição" e a "ressemantização do termo quilombo", substituindo-se a visão histórica pela étnica e permitindo-se "criar um quilombo lá onde este não existia". 498

Observa esse autor que o termo "quilombo", utilizado pela Constituição, tinha uma acepção muito precisa em 1988, abrangendo comunidades de ex-escravos, que haviam fugido de seus senhores e passaram a ocupar terras livres, em áreas geralmente isoladas. A partir de certo momento, porém, substituiu-se o "quilombo histórico" pelo "quilombo conceitual", alargando a significação do termo até descaracterizá-lo. Essa alteração de significado, é ainda Rosenfield que aponta,

“ visa a um sem-número de casos possíveis, abrangendo, praticamente, qualquer relação social, trabalhista ou outra em que negros estejam ou tenham estado em maior ou menor medida envolvidos. Assim, doações de terras e heranças, contempladas no Código Civil, vêm a ser consideradas como quilombolas, quando uma cadeia dominial pode perfeitamente ser traçada conforme as diferentes responsabilidades. Da mesma maneira, relações de trabalho, previstas na legislação trabalhista, tornam-se também quilombolas, porque assim o quiseram aqueles que se apropriaram da nova significação de quilombo. Compra de terras, outra transação comercial normal, igualmente prevista em lei, torna-se, ela também, quilombola. Os marcos temporais igualmente desaparecem. Parece não haver limites para tal ampliação do conceito de quilombo".

O resultado, segundo dados da Fundação Cultura Palmares (órgão do Ministério da Cultura), fala por si: entre 1995 e 1998, era reconhecida a existência

${ }^{498}$ Denis L. Rosenfield, A Captura da Constituição, jornal O Estado de S. Paulo, ed. 10.5.2010. 
de 24 quilombos no Brasil. Em 2010, o número aproximava-se de 5 mil, e continuava a crescer. $^{499}$

Diante desse quadro, não surpreende a ocorrência de situações no mínimo inusitadas. É o caso de processo administrativo aberto pelo INCRA para reconhecer, como remanescente de um quilombo, imóvel de regular e vetusta propriedade da Venerável Ordem Terceira de São Francisco da Penitência, no centro do Rio de Janeiro ${ }^{500}$. Ou, ainda, de grandes extensões da Ilha de Marambaia, adquiridas pela União em 1905, e ocupadas há décadas pela Marinha brasileira, cuja propriedade é reivindicada por descendentes de escravos, que ali construíram recentemente algumas modestas habitações ${ }^{501}$. Já começam a aparecer referências, na imprensa, aos assim chamados quilombos urbanos, formados há poucos anos, mediante invasão de prédios abandonados $^{502}$, algumas vezes salientando-se o "caráter explosivo" da questão ${ }^{503}$

${ }^{499}$ Apud Denis Rosenfield, artigo citado.
500 A Ordem tem títulos de propriedade sobre essa área que remontam a 1704, além de documento
assinado pelo então Príncipe Regente D. Pedro, em 1821 , reconhecendo-lhe "o senhorio directo de
terrenos" ocupados sem interrupção até os dias de hoje, em que realiza trabalhos sociais, como a
manutenção de uma escola para mais de mil alunos carentes (veja-se, a respeito, o artigo Quilombos
Urbanos, de Denis Rosenfield - jornal O Estado de S. Paulo, edição de 29.10.2007, p. A-2). No
entanto, em decisão liminar do TRF da $1^{\text {a }}$. Região, no agravo de instrumento n. 2007.01.00.052659-8-
DF, tirado contra decisão que suspendia processos administrativos de demarcação de terras da citada
Ordem, o relator afirma: "pouco importa o quão venerável e importante é a Agravada, e de que data
provém a propriedade e posse que diz ter", e "inócuo também discutir quantas são as pessoas que
terão direito às terras e quais suas dimensões ou a relevância de sua destinação atual". A prevalecer
um tal raciocínio - cuja expressão inicial bem revela o radicalismo que o perpassa - nenhum imóvel,
público ou particular, em qualquer parte do território nacional, estará livre de ser reivindicado, até em
virtude de ocupação recente, por auto-declarados descendentes de escravos, cabendo o dificílimo
ônus da prova em contrário aos atuais proprietários, pouco importando a data a que remontam seus
títulos de domínio ou a função social com que este seja exercido.

${ }^{501}$ Ação de reintegração de posse relativa a essa área, movida pela própria União, foi julgada procedente na primeira e segunda instâncias da Justiça Federal, mas tal decisão foi revertida pelo Superior Tribunal de Justiça, no Recurso Especial n. 931.060-RJ. A afirmação quanto ao caráter recente das construções, com base nas quais é reivindicada a propriedade da área, consta do acórdão proferida pelo Tribunal Regional Federal da $2^{\mathrm{a}}$. Região, que também adotou a leitura da Constituição que aqui defendemos, conforme se pode ler na ementa: "1. O conceito jurídico de remanescentes das comunidades dos quilombos não pode se apartar da própria noção histórica acerca dos quilombos. Devido à prova de que a Ilha de Marambaia, nos idos do período da escravidão de pessoas de cor negra no Brasil, servia como entreposto do tráfico de escravos, não seria de se considerar possível que no mesmo arquipélago fossem também instaladas comunidades integradas por escravos fugidos e as famílias que eles passaram a compor". Esses dados estão mencionados nos votos proferidos no aludido recurso especial, disponíveis no endereço eletrônico do Superior Tribunal de Justiça (www.stj.gov.br, acesso em 24.11.2010).

502 O jornal O Estado de S. Paulo, na edição eletrônica de 15.12.2010, registra a concessão de um prêmio a fotógrafo estrangeiro que registrou cenas de um quilombo urbano em Salvador, resultado da 
Há, certamente, muitos defensores dessa espécie de reforma agrária orientada por critério racial. Como exemplo, podemos citar texto da antropóloga Ilka Boaventura Leite, professora da Universidade Federal de Santa Catarina, com o sugestivo título de "O Projeto Político Quilombola". Após informar que o termo quilombo provém do idioma bantu ${ }^{504}$, com o significado de "acampamento guerreiro na floresta", incorporado ao português do Brasil desde a época colonial para referir-se "às unidades de apoio mútuo criadas pelos rebeldes ao sistema escravista e às suas reações, organizações e lutas pelo fim da escravidão", a professora passa a defender uma definição inteiramente nova do termo, que implica o abandono do sentido vernacular:

"O quilombo como um direito constitucional passou então a abranger um conjunto muito amplo de práticas e experiências, atores e significados - sempre carregando o sentido ou desdobrandose dele, dos mais diversos modos de reação às formas de dominação instituídas pelo processo colonial escravista -, ampliando-se para um conjunto incalculável de situações dele decorrentes.

Foi, sem dúvida, o prolongamento dessas reações até os contextos pós-coloniais o que conferiu ao quilombo um significado trans-histórico - que o destituiu dos marcos cronológicos ou espaciais rígidos -, propiciando a sua correlação ou relação de continuidade com os direitos pleiteados durante o período recente de redemocratização do País. O quilombo assume, portanto, um papel emblemático nas lutas dos negros e em suas reivindicações por cidadania nos diversos períodos da história, sendo este momento atual mais um deles. A sua dinâmica revela que o conjunto de transformações por ele engendrado transcende o que convencionalmente tem sido tratado como agenda política exclusiva

ocupação, há sete anos, de uma fábrica de chocolates abandonada, por pessoas que antes viviam nas ruas (http://www.estadao.com.br/noticias/geral,fotos-de-quilombo-urbano-em-salvador-ganhampremio-britanico,653973,0.htm ).

503 "Reconhecimento de áreas quilombolas urbanas é explosivo" - O Estado de S.Paulo, edição eletrônica, 1.7.2009 - http://www.estadao.com.br/noticias/nacional,reconhecimento-de-areasquilombolas-urbanas-e-explosivo,396324,0.htm).

${ }^{504} \mathrm{Na}$ verdade, como registra o Dicionário Houaiss, "banto" é o nome de um povo africano, e quimbundo o seu idioma. 
do movimento social. As transformações que o quilombo instaura são muito mais amplas e, portanto, de cunho eminentemente identitário.

A pergunta que parece mais recorrente hoje quando buscamos entender esse processo é mesmo sobre a força daquilo que veio a ser caracterizado como "projeto Quilombola", quando o quilombo passa paulatinamente a condensar, a integrar diversas noções de direito que abrangem não só o direito a terra mas todos os demais; quando esse vai do território às manifestações artísticas; quando o direito quilombola quer dizer educação, água, luz, saneamento, saúde, todos os direitos sociais até então negados a essas populações; quando o direito vai do campo à cidade, do individual ao coletivo; e, principalmente, quando o quilombo como direito confronta projetos e modelos de desenvolvimento, questiona certas formas de ser e viver, certos usos dos recursos naturais, seus usufrutos, o parentesco, a herança, as representações políticas e muito mais; quando o quilombo deixa de ser exclusivamente o direito a terra para ser a expressão de uma pauta de mudanças que, para serem instauradas, precisam de um procedimento de desnaturalização dos direitos anteriores: de propriedade, dos saberes supostos sobre a história, dos direitos baseados nas concepções de público e privado, entre tantos outros.

Considero, neste sentido, que o quilombo como direito vem alterando a própria ordem da Nação, dos discursos que sustentam ou sustentaram as mais diversas concepções de Nação, e não é por acaso que há hoje tantas reações que visam desestabilizá-lo: desde o questionamento sobre o suposto sujeito do direito até as formas de exercício do direito assinalado no texto constitucional. (...)

Mesmo diante da lentidão dos processos de titulação, da erosão das mobilizações atuais provocadas pelas retomadas das velhas estratégias clientelísticas de cooptação das lideranças para os quadros administrativos do Estado e de algumas políticas meramente assistencialistas, o quilombo continua representando insurgência, mais do que acomodação e apaziguamento.

Reafirmo, neste sentido, que o quilombo como direito tornou-se uma espécie de potência que atravessa hoje a sociedade e o Estado - embaralhando as identidades fixas e a configuração do 
parentesco, do local, regional, nacional e transnacional, e, principalmente, instaurando grandes dúvidas sobre a capacidade do Estado de ser o gestor da cidadania e o ordenador do espaço territorial." 505

\subsubsection{Análise originalista}

A controvérsia objeto deste tópico é um claro exemplo de deturpação de um texto normativo, somente possível por meio de artifícios interpretativos. Um único vocábulo, de significado consagrado na língua portuguesa, colocado em uma disposição transitória da Carta de 1988, que reconhece a propriedade de algumas poucas áreas a um pequeno e bem delimitado grupo de pessoas, com o passar do tempo transfigura-se em lema de uma abrangente plataforma política que, como visto, pretende alterar a "ordem da Nação", questionando até mesmo a capacidade do Estado brasileiro de exercer a soberania sobre seu território...

Não há mal nenhum, por certo, em defender um ideário político transformador da sociedade. A própria implantação do Estado Constitucional foi, a seu tempo, uma idéia revolucionária. Os meios adequados para intervir na realidade social, todavia, estão à disposição de todos, segundo os processos democráticos, e no foro legitimado para tanto: o parlamento.

A Constituição foi promulgada no centenário da abolição da escravatura. O mesmo constituinte que destinou cerca de dez por cento do território nacional às populações indígenas ${ }^{506}$, poderia, se quisesse, ter adotado um critério étnico para realizar a reforma agrária, como forma de reparação histórica às injustiças sofridas pelos escravos. Contudo, não o fez. Na parte permanente da Constituição, proibiu discriminação com base na raça (art. $3^{\circ}$., inciso IV), estabeleceu tratamento

${ }^{505}$ Ilka Boaventura Leite, O Projeto Político Quilombola: Desafios, Conquistas e Impasses Atuais", 2008 (disponível em http://www.scribd.com/doc/26744541/O-PROJETO-POLITICOQUILOMBOLA\#;). Foi rigorosamente mantida a redação original.

${ }^{506}$ CF, art. 291. Ver Ives Gandra da Silva Martins, Comentários, cit. p. 490. 
extremamente rigoroso para o crime de racismo (art. $5^{\circ}$, inciso XLII) e determinou o reconhecimento e preservação da cultura afro-brasileira (arts. $215, \S 1^{\circ}$ e $216, \S 5^{\circ}$.). Junto a essas relevantes disposições, acrescentou, já na parte transitória da Carta, o dispositivo reconhecendo aos remanescentes dos antigos quilombos a propriedade das terras que estivessem ocupando. Há uma evidente gradação nessas medidas, reveladas não só pela linguagem, mas também pelo aspecto topológico.

Pondo de lado as óbvias implicações políticas da questão, parecenos evidente, sob o ângulo estritamente jurídico, que a aludida "ressemantização" configura uma violação da vontade do constituinte, desfigurando totalmente um preceito que, ao tempo de sua edição, não oferecia nenhuma dúvida quanto ao seu exato alcance. Pressões de natureza política, exercida sobre o Poder Executivo federal, vêm logrando alcançar resultados não previstos nem autorizados pela Constituição.

A conclusão a que chegamos é que o enfoque originalista do art. 68 do ADCT - se vier a ser levado em conta pelo Supremo Tribunal Federal no julgamento da ADI 3239 - levaria a uma solução juridicamente adequada da controvérsia, fazendo respeitar o intuito do constituinte e preservando o significado com que o texto foi entendido ao tempo de sua promulgação, evitando-se, por conseguinte, deformações advindas de exageros interpretativos.

\subsection{Balanço e perspectivas.}

Examinados os tópicos propostos neste capítulo, é possível esboçar algumas conclusões.

Vimos que tanto a doutrina constitucional brasileira recente, como a jurisprudência do Supremo Tribunal Federal, após 1988, têm algumas vezes adotado, 
de forma eventual, a abordagem originalista, no mais das vezes como um argumento de reforço. Em diversos casos, ainda que não tenha prevalecido na solução das controvérsias, ela se mostrou como um elemento valioso para a busca de soluções justas e adequadas, demonstrando suas potencialidades como freio aos excessos do ativismo judicial.

Embora seja prematuro qualquer prognóstico quanto à continuidade da análise originalista em futuros julgamentos, ou à sua maior aceitação pela doutrina, consideramos altamente positiva sua prevalência no recente julgamento da Arguição de Preceito Fundamental n. 153. A alta relevância e o pioneirismo dessa decisão, em que pela primeira vez essa técnica foi majoritariamente adotada pelo Supremo Tribunal Federal, permitem traçar um paralelo, guardadas as devidas proporções, com o significado do caso District of Columbia v. Heller na história da jurisprudência da Suprema Corte dos Estados Unidos.

A nosso ver o Direito Constitucional brasileiro seria enriquecido se esse tipo de análise vier a prosperar, alertando os constituintes do futuro para a importância de que suas decisões sejam claras, e que o processo de criação das normas constitucionais seja sempre público e amplamente divulgado, abolindo os acordos "a portas fechadas" e evitando brechas interpretativas capazes de ensejar a insegurança jurídica. De outra parte, ganhará o Brasil sem evoluirmos para um estágio em que as grandes decisões nacionais, respeitados os limites originalmente estabelecidos pela Constituição, sejam tomadas não pelas Cortes de Justiça, no exercício de postura ativista, mas pelo verdadeiro soberano, o povo, através de representantes eleitos e responsáveis, após o saudável e debate no mais democrático dos foros, o Parlamento. 


\section{CONCLUSÕES}

1. A interpretação consiste na atividade que visa descobrir o significado de um texto. Ao exercer essa função mediadora, o intérprete deve evitar atribuir ou construir um significado segundo suas inclinações pessoais. Há necessidade, pois, de atentar para os limites da interpretação.

2. A missão do intérprete, na seara jurídica, é descobrir o conteúdo real da norma. Tratase de um ato de conhecimento, não de vontade.

3. Os métodos ou elementos básicos para a interpretação jurídica - gramatical, lógico, histórico e sistemático - estão necessariamente relacionados, e devem ser aplicados conjuntamente, de forma complementar.

4. A distinção entre interpretação objetiva e subjetiva deve ser relativizada, mesmo porque, como salienta Alf Ross, toda interpretação parte da comunicação e procura chegar à intenção. $\mathrm{O}$ intérprete deve-se valer de todas as circunstâncias que possam esclarecer o significado do texto

5. A interpretação constitucional tem peculiaridades, basicamente decorrentes da supremacia da Constituição e seu caráter de norma fundante da ordem jurídica, assim como o fato de conter grande número de princípios e conceitos abertos. O significado das normas constitucionais espraia-se por todo o ordenamento jurídico. Daí a especial relevância e especificidade da interpretação constitucional.

6. Em tema de interpretação constitucional, têm sido proposta a adoção de métodos específico. No entanto, é perfeitamente aplicável o método clássico, com base nos quatro elementos identificados por Savigny (gramatical, lógico, histórico e sistemático), desde que se leve em conta as peculiaridades já referidas. 
7. A lei pode ser "mais inteligente que o legislador", na medida em que deve ser lida em conjunto com outras normas de igual hierarquia, e todas sob o crivo daquela que é superior a todas, a Constituição. No entanto, como ensina Ives Gandra da Silva Martins, a Constituição não é "mais inteligente que o Constituinte", uma vez que não existem normas de igual hierarquia, nem qualquer outra que lhe seja superior. O parâmetro para interpretar a Constituição é apenas ela mesma.

8. A vontade do constituinte, quando passível de ser conhecida, é de grande importância para a adequada interpretação do texto constitucional. Sua objetivação, no texto da Constituição, representa os compromissos coletivamente assumidos em virtude da soberania popular, traduzindo-se na tomada de decisões constitucionais que não devem ficar sujeitas a oscilações decorrentes de preferências ou inclinações de cada um dos intérpretes.

9. É legítimo recorrer aos trabalhos preparatórios da elaboração da Constituição, com vistas à busca do melhor entendimento de seus dispositivos.

10. Têm profundas raízes no constitucionalismo norteamericano as idéias de autocontenção judicial e respeito às decisões fundamentais dos Pais Fundadores.

11. O ativismo, como tendência que prega o desapego dos juízes ao texto da constitucional, favorecendo mudanças constitucionais pela via jurisprudencial, ganhou força nos Estados Unidos a partir do século XX, em especial com a jurisprudência da Corte Warren, a partir do caso Brown v. Board of Education, de 1954. Muitas das decisões de cunho ativista, porém, foram vivamente contestadas, especialmente a que reconheceu um direito constitucional ao aborto, não previsto no texto da Constituição.

12. O originalismo surgiu como reação aos excessos do ativismo judicial. Inicialmente ligado à idéia de respeito à "intenção original", passou a defender a defender a 
interpretação da Constituição segundo o "entendimento original" de seu texto e reconhecendo o valor dos precedentes estabelecidos.

13. Nos Estados Unidos, o originalismo tem sido o centro dos debates sobre interpretação constitucional nas últimas décadas, ganhando cada vez maior relevância, seja no âmbito acadêmico, seja no plano jurisprudencial. Está solidamente estabelecido na atual composição da Suprema Corte. No julgamento do caso District of Columbia v. Heller, de 2008, pela primeira a argumentação originalista foi adotada pela maioria da Corte, restabelecendo o que se acredita ser o sentido original da Segunda Emenda à Constituição.

14. Considerada a atual composição da Suprema Corte, parece provável que o originalismo continuará a ser uma tendência influente no futuro próximo.

15. A interpretação de cunho originalista, que procura preservar o sentido com que foram concebidas as normas constitucionais, é também praticada em outros países.

16. O originalismo moderado é adotado de forma consistente na Austrália, onde coexiste com outros critérios interpretativos.

17. O enfoque originalista está presente numa das mais relevantes polêmicas do constitucionalismo japonês, relativa à chamada "cláusula pacifista", em que é defendido por setores progressistas da sociedade.

18. Na Europa, os Tribunais e Cortes constitucionais, pela sua posição institucional, composição e forma de investidura, têm indiscutível legitimidade política para reinterpretar a Constituição. Mesmo assim, também se observa eventualmente o enfoque originalista em Portugal, Espanha e Itália.

19. Na Argentina, o critério originalista já foi dominante na atuação da Suprema Corte, no início do século XX. Hoje em dia, está consolidado naquele Tribunal o entendimento de que a primeira regra de interpretação consiste em dar efeito à intenção do legislador (o que vale, também, para a Constituição), mas sem deixar de lado numerosos outros critérios, 
que levam em conta o respeito aos precedentes, o exame das conseqüências práticas das decisões judiciais e a contínua evolução da sociedade.

20. No Chile, a interpretação originalista é dominante na doutrina mais tradicional e na jurisprudência do Tribunal Constitucional. A fonte dessa interpretação consiste nas atas de reuniões da Comissão de Estudos da Nova Constituição (também conhecida como “Comissão Ortúzar”), na década de 1970, até hoje consideradas como a manifestação "autêntica" quanto ao significado das disposições constitucionais. Doutrinadores mais modernos criticam o apego excessivo a essa fonte, por considerá-la ilegítima.

21. No Brasil, o respeito à intenção do legislador era considerado absolutamente natural ao tempo do Império. De fato, a Constituição de 1824 atribuía somente ao Poder Legislativo o poder de interpretar as leis e velar pela supremacia da Constituição.

22. Nas primeiras décadas da República, era muito prestigiado o enfoque originalista em matéria constitucional, especialmente sob a vigência da Carta de 1891.

23. Embora não seja muito prestigiado pela atual doutrina, a técnica originalista é eventualmente adotada em julgamentos importantes do Supremo Tribunal Federal, tendo sido decisiva para a solução da importante controvérsia relativa à proposta de reinterpretação da Lei de Anistia [ADPF 153], em que foi adotada por ampla maioria da Corte.

24. Uma atenção maior aos critérios originalistas, como critério complementar a outras técnicas de interpretação, representaria fator de enriquecimento do constitucionalismo brasileiro, colaborando para se alcançar soluções justas e adequadas ás controvérsias constitucionais, sendo também um meio eficaz para contenção dos excessos do ativismo judicial. 


\section{BIBLIOGRAFIA}

ACCIOLI, Wilson. Instituições de Direito Constitucional. Rio de Janeiro: Forense, 1978.

ACCIOLY, Janine Adeodato. Perda de Mandato Eletivo por Infidelidade Partidária. Trabalho apresentado em Curso de Especialização em Direito e Processo Eleitoral da Escola Superior da Magistratura do Estado do Ceará (disponível no endereço eletrônico www.bdjur.tjce.jus.br).

AGRA, Walber de Moura. Curso de Direito Constitucional. Rio de Janeiro: Forense, 2006 (tb. consultada a 4ª . ed., Gen/Forense, 2008).

AIETA, Vânia Siciliano. Partidos Políticos (t. IV do Tratado de Direito Político - Estudos em Homenagem ao Prof. Siqueira Castro). Rio de Janeiro: Lumen Juris, 2006.

ALENCAR, José de. Systema Representativo. Brasília: Senado Federal, 1997 (reprodução fac-similar do original de 1868).

ALDUNATE LIZANA, Eduardo. Consideraciones Preliminares para una Teoría de la Interpretación Jurídica. Revista Chilena de Derecho, número especial, 1990, pp. 27-31.

ALDUNATE LIZANA, Eduardo. Derechos fundamentales. Santiago: Editorial Legal Publishing, 2008.

ALONSO GARCÍA, Enrique. La Interpretación de la Constitución. Madri: Centro de Estudios Constitucionales, 1984.

AMARAL Jr., José Levi Mello do. Memória Jurisprudencial: Ministro Aliomar Baleeiro. Brasília: Supremo Tribunal Federal, 2006.

ANDRADE, Christiano José de. O Problema dos Métodos da Interpretação Jurídica. São Paulo: RT, 1992.

ANDRADE, Manuel A. Domingues de. Ensaio sobre a Teoria da Interpretação das Leis. Coimbra: Arménio Amado, 1987.

ARAS, Augusto. Fidelidade Partidária: A Perda do Mandato Parlamentar. Rio de Janeiro: Lumen Juris, 2006.

ARAÚJO CASTRO. A Nova Constituição Brasileira. Rio de Janeiro: Freitas Bastos, 1936.

Ribeiro, 1924.

. A Reforma Constitucional. Rio de Janeiro: Livraria Editora Leite

ATALIBA, Geraldo. Revisão Constitucional. Revista de Informação Legislativa, n. 110, abr./jun 1991, pp. 87-90

AUER, James. Article Nine of Japan's Constitution: From Renunciation of Armed Force "Forever" to the Third Largest Defense Budget in the World. Law and Conteporary 
Problems, 1990, 171 (disponível em http://www.jstor.org/pss/1191849; acesso em 17.11.2010).

AVILÉS Hijo, Víctor Manuel. Interpretación Constitucional. Artigo disponível em www.u-cursos.cl/derecho/2008/2/D123A0209/2/material_docente/objeto/197723 (acesso em 19.11.2010).

BARBALHO, João. Constituição Federal Brasileira. Brasília: Senado Federal, 1992 (edição fac-similar do original de 1902).

BARBER, Sotirios A. FLEMING, James E. Constitutional Interpretation: the basic questions. New York: Oxford University Press, 2007.

BARBOSA, Rui. Comentários à Constituição Federal Brasileira (coligidos e ordenados por Homero Pires). São Paulo: Saraiva \& Cia., 1993.

BARNETT, Randy. Restoring the Lost Constitution: the presumption of Liberty. Princeton: Princeton University Press, 2004.

BARROSO, Luís Roberto. Interpretação e Aplicação da Constituição. São Paulo: Saraiva, $7^{\mathrm{a}}$. ed., 2009.

Ingerência constitucional do Judiciário na vida política brasileira: o ativismo judiciário, a judicialização da política e o novo enfoque do mandado de injunção. Anais da VI Conferência dos Advogados do Distrito Federal, 2008, pp. 88-97.

Prudências, ousadias e mudanças necessárias no STF Consultor Jurídico, 28.12.2010 (disponível em http://www.conjur.com.br/2010-dez28/retrospectiva-2010-prudencias-ousadias-mudancas-necessarias-stf; $\quad$ acesso em 28.12.2010).

BASSA MERCADO, Jaime. El Estado Constitucional de Derecho. Efectos sobre la Constitución vigente y los derechos sociales, LexisNexis, Santiago: ed. Lexis Nexis, 2008.

BASSA MERCADO, Jaime. Sobre la dogmática de los derechos fundamentales. Publicado no sítio da Universidade de Viña Del Mar: http://www.uvm.cl/juridicasysociales/articulos.shtml?cmd\%5B291\%5D=i-291-

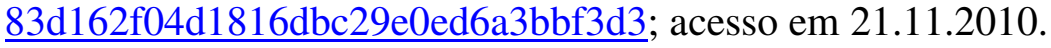

BASTOS, Celso Ribeiro. Hermenêutica e Interpretação Constitucional. São Paulo: Celso Bastos Editor, 2a . ed., 1999.

Curso de Direito Constitucional. São Paulo: Saraiva, $18^{\mathrm{a}}$. ed.,

1997.

BASTOS, Celso Ribeiro. MARTINS, Ives Gandra. Comentários à Constituição do Brasil. Vol. I. São Paulo: Saraiva, 1988. Vol. II, 1989. Vol. IX, 3ª ed., 2002.

BASTOS, Celso Ribeiro. TAVARES, André Ramos. As Tendências do Direito Público no limiar de um novo milênio. São Paulo: Saraiva, 2000. 
BELTRÁN DE FELIPE, Miguel. Originalismo e Interpretación - Dworkin vs. Bork: uma polêmica constitucional. Madri: Editorial Civitas, 1989.

BERGER, Raoul. Government by Judiciary - The Transformation of the Fourteenth Amendment. Indianapolis: Liberty Fund, 1997.

BERMAN, Mitchel N. Originalism and its discontents. Texto disponível em http://findarticles.com/p/articles/mi_hb3086/is_2_24/ai_n29437658/?tag=content;col1; acesso em 10.01.2010.

BETTI, Emílio. Interpretação da Lei e dos Atos Jurídicos. São Paulo: Martins Fontes, 2007 [tradução de Interpretazione della Legge e degli Atti Giuridici].

BICKEL, Alexander M. The Least Dangerous Branch: the Supreme Court at the Bar of Politics. New Haven: Yale University Press, 2a. ed., 1986.

BIDART CAMPOS, G.J. La Corte Suprema: el Tribunal de las Garantias Constitucionales [atualizado por Pablo L. Manili]. Buenos Aires: Ediar, 2010.

Ediar, 1967.

. El Derecho Constitucional del Poder (t. I). Buenos Aires?

BITTENCOURT, C.A. Lúcio. O Controle Jurisdicional da Constitucionalidade das Leis. Atualizado por José de Aguiar Dias. Rio de Janeiro: Forense, $2^{\mathrm{a}}$ ed., 1968.

BLACK, Henry Campbell. Handbook on the Construction and Interpretation of the Laws. St. Paul, Minesotta: West Publishing Co., 1911 [reprodução fac-similar de domínio publico, 2010].

BÖCKENDFORDE, Ernst-Wolfgang. Stato, costituzione, democrazia. Milão: Giuffrè, 2006 [tradução do original alemão: Staat, Verfassung, Demokratie. Studien zur Verfassungstheorie und zumVerfassungsrecht, 1991].

BONAVIDES, Paulo. A Constituição Aberta. Belo Horizonte: Del Rey, 1993.

Teoria do Estado. São Paulo: Malheiros, $3^{\text {a }}$. ed., 1995.

O método tópico de interpretação constitucional. Lições de Direito Constitucional em Homenagem ao Jurista Celso Bastos (coord. André R. Tavares, Gilmar F. Mendes e Ives Gandra da S. Martins). São Paulo: Saraiva, 2005.

BORK, Robert H. The Tempting of America: the political seduction of the Law. New York: Touchstone, 1991.

A Time to Speak: selected writings and arguments. Wilmington, Delaware: ISI Books, 2009.

BRASIL. Assembléia Nacional Constituinte. Diários. Brasília: Imprensa Nacional, 1987-1988 (obtidas no Centro de Documentação e Informação da Câmara dos Deputados.

Forense, 1987.

Constituição Federal: anteprojeto da Comissão Afonso Arinos. Rio de Janeiro: 
Senado Federal. A Constituição que não foi: História da Emenda Constitucional n. 1, de 1969. Brasília, 2002.

Supremo Tribunal Federal. Ação Direta de Inconstitucionalidade n. 4-7-DF (julgamento em 7.3.1991). Disponível em www.stf.jus.br.

- Supremo Tribunal Federal. Arguição de Descumprimento de Preceito Fundamental n. 153-DFI. Disponível em www.stf.jus.br .

- Supremo Tribunal Federal. Habeas Corpus n. 82.424-RS (julgamento de 12.2.2002 a 19.09.2003). Disponível em www.stf.jus.br; publicado em Crime de Racismo e Anti-Semitismo, Brasília: Brasília Jurídica, 2004.

. Supremo Tribunal Federal. Recurso Extraordinário n. 134.509-8 - Amazonas (julgamento de 8.9.1994 a 29.5.2002). Disponível em www.stf.jus.br - acesso em 31.10.2010.

. Tribunal de Justiça do Estado de São Paulo. Habeas Corpus 131.798-3/2, julgamento em 13.10.1992 (cópia obtida no próprio tribunal).

BRITO, Miguel Nogueira de. Originalismo e Interpretação Constitucional. In Interpretação Constitucional - Virgilio Afonso da Silva (org.). São Paulo: Malheiros, 2007.

BRONNER, Ethan. Battle for Justice: How the Bork Nomination Shook America. New York: W.W. Norton \& Co., 1989.

BULOS, Uadi Lammêgo. Curso de Direito Constitucional. São Paulo: Saraiva, 1a . ed., 2007; 5a. ed., 2010.

2002.

Constituição Federal Anotada. São Paulo: Saraiva, 4a . ed.,

CAETANO, Marcelo. Direito Constitucional (v. II). Rio de Janeiro: Forense, $2^{\mathrm{a}}$ ed., 1987.

CAGGIANO, Monica Herman Salem. Direito Parlamentar e Direito Eleitoral. São Paulo: Manole, 2004.

CALABRESI, Steven G. (ed.). Originalism: a quarter-century of debate. Washington: The Federalist Society, 2007.

CALIMAN, Auro Augusto. Mandato Parlamentar: aquisição e perda antecipada. São Paulo: Atlas, 2005.

CAMARGO, Margarida Maria Lacombe. Hermenêutica e Argumentação - Uma Contribuição ao Estudo do Direito. Rio de Janeiro: Renovar, 1999.

CANOtILHO, J.J. Gomes. Direito Constitucional e Teoria da Constituição. Coimbra: Almedina, 2000.

CARNEIRO, Levi. Pela Nova Constituição. Rio de Janeiro: A. Coelho Branco Fo ., 1936. 
CARVALHO, Kildare Gonçalves. Direito Constitucional. Belo Horizonte: Del Rey, 12a. ed., 2006.

CARVALHO, Paulo de Barros. Direito Tributário, Linguagem e Método. São Paulo: Noeses, 2009.

CAVALCANTI, Themístocles Brandão. Do Controle da Constitucionalidade. Rio de Janeiro: Forense, 1966.

CHEMERINSKY, Erwin. Constitutional Law: Principals and Policies. New York: Aspen Publishers, 3a. ed., 2006.

CHINEN, Mark. Article 9 of the Constitution of Japan and the use of procedural and substantive heuristics for consensus. Michigan Journal of International Law, n. 27, 2006, pp. 55-114.

CÓDIGO DE DIREITO CANÔNICO - Promulgado pelo Papa João Paulo II. Ed. Loyola, $2^{\mathrm{a}}$. Ed., São Paulo, 1987.

COELHO, Inocêncio Mártires. Interpretação Constitucional. $3^{\mathrm{a}}$. ed. - São Paulo: Editora Saraiva, 2007.

CRETELLA JÚNIOR, José. Comentários à Constituição Brasileira de 1988. São Paulo: Forense Universitária. 2a . ed., 1994.

COUTO, Ronaldo Costa. História Indiscreta da Ditadura e da Abertura: Brasil: 19641985. Rio de Janeiro: Record, 1998.

CUNHA, Sérgio Sérvulo da. Reforma Eleitoral Partidária. Revista de Informação Legislativa n. 125, 1995.

DIMOULIS, Dimitri. Positivismo Jurídico. São Paulo: Método, 2006.

DUARTE, José. A Constituição Brasileira de 1946. Rio de Janeiro, 1947.

DUCROT, Oswald. TODOROV, Tzvetan. Dicionário Enciclopédico das Ciências da Linguagem. São Paulo: Perspectiva, 1988.

DWORKIN, Ronald. Freedom's Law: the moral reading of the American Constitution. Cambridge: Harvard University Press, 1996. [também consultada a tradução brasileira: O Direito da Liberdade: a leitura moral da Constituição norte-americana. São Paulo: Martins Fontes, 2006].

2005 [tradução de A Matter of Principle, Harvard University Press, 1985].

ECO, Umberto. Os limites da interpretação. São Paulo: Perspectiva, 1995 (tradução de $I$ Limitti dell'Interpretazione, 1990).

ELY, John Hart. Democracy and Distrust - A theory of judicial review. Cambridge: Harvard University Press, 1980 [consultada também a tradução brasileira: Democracia e Desconfiança - São Paulo: Martins Fontes, 2010]. 
FAUSTO, Boris. História do Brasil. São Paulo: EDUSP, 1994.

FAVOREU, Louis. As Cortes Constitucionais. São Paulo: Landy, 2004.

FERRARA, Francesco. Interpretação e Aplicação das Leis. Coimbra: Arménio Amado, 1987.

FERREIRA FILHO, Manoel Gonçalves. Curso de Direito Constitucional. São Paulo: Saraiva, $31^{\text {a }}$. ed., 2005.

Saraiva, 1990. Vol. 4, 1995.

Comentários à Constituição Brasileira de 1988. Vol. 1, São Paulo: O Anteprojeto dos Notáveis. São Paulo: Saraiva, 1987.

Do Processo Legislativo. São Paulo: Saraiva, 6ª ed., 2007.

- Comentários à Constituição Brasileira. São Paulo: Saraiva, 2a .

ed., 1977, vol. 1.

Poder Judiciário da Constituição de 1988: judicialização da política e politização da justiça. Revista de Direito Administrativo, vol. 198, pp. 1-17. Rio de Janeiro: Renovar, 1994; também publicado em Aspectos do Direito Constitucional Contemporâneo - São Paulo: Saraiva, 2003 (pp. 189-216).

FREIRE, Felisbello. História Constitucional da República dos Estados Unidos do Brasil. Rio de Janeiro: Typographia Moreira Maximino, Chagas \& Cia. Vol. I, 1894. Vol. III, 1895.

GADAMER, Hans-Georg. Verdade e Método. Petrópolis: ed. Vozes, 3a. ed., 1998 [tradução do original alemão: Wahrheit und Methode, 1986].

GASPARI, Elio. A Ditadura Encurralada. São Paulo: Cia. das Letras,2004.

GIUFFRÈ, Felice. NICOTRA, Ida. Lavori Preparatori ed Original Intent nella Giurisprudenza della Corte Costituzionale. Turim: G.Giappichelli Editore, 2008.

GOLDSWORTHY, Jeffrey (org.) - Interpreting Constitutions - A Comparative Study. Oxford University Press, 2006.

GOMES, José Jairo. Direito Eleitoral. Belo Horizonte: Del Rey, 4ª ed., 2010.

GONZÁLEZ, Horácio Ricardo. Los derechos fundamentales y la emergencia en Argentina. Disponível em http://www.cajuridico.com.ar/index.php?cat=Informe_20022003/Debates\&ver=debate_14 - acesso em 19.11.2010).

GRAU, Eros Roberto. Ensaio e Discurso sobre a Interpretação/Aplicação do Direito. São Paulo: Malheiros, 2002.

GREENBERG, Mark. LITMAN, Harry. The Meaning of Original Meaning. Disponível $\mathrm{em}$ http://ssrn.co m/abstract=855408 (acesso em 10.01.2010). 
GRIFFIN, Stephen M. Rebooting Originalism. Disponível em: http://lawreview.law.uiuc.edu/publications/2000s/2008/2008_4/Griffin.pdf (acesso em 10.01.2010).

HAGE, Jorge. Omissão Inconstitucional e Direito Subjetivo. Brasília: Brasília Jurídica, 1999.

HESPANHA, António Manuel. Hércules Confundido: sentidos improváveis e incertos do constitucionalismo oitocentista: o caso português. Curitiba: Juruá Editora, 2009.

HESSE, Konrad. A Força Normativa da Constituição. Porto Alegre: Sérgio Fabris, 1991 [tradução de Die Normative Kraft der Verfassung].

HOMEM DE MELLO, Francisco Ignácio Marcondes. (Barão Homem de Mello). A Constituinte perante a História. Brasília: Senado Federal, 1996 (reprodução fac-similar do original de 1863).

JACQUES, Paulino. Curso de Direito Constitucional. Rio de Janeiro: Forense, 10ª . ed., 1987.

A Constituição Explicada. Rio de Janeiro: Forense, $3^{\text {a }}$. ed., 1970.

Japão. Suprema Corte. Sunakawa Case. 16 de dezembro de 1959, registro n. 710/1959. Disponível em www.courts.go.jp/english/judgments (acesso em 2/1/2011).

.Case concerning Hyakuri Base, 20 de junho de 1989, registro ns. 162 e 165/1982. Disponível em www.courts.go.jp/english/judgments (acesso em 2.1.2011).

LAMY, Marcelo. Reflexões sobre a fidelidade partidária. São Paulo: Escola Superior de Direito Constitucional, 2007 (texto disponível em www.esdc.com.br; acesso em 8.12.2010).

LARENZ, Karl. Metodologia da Ciência do Direito. Lisboa: Fundação Calouste Gulbenkian, 2009.

LAW, David. S. The Anatomy of a Conservative Court: Judicial Review in Japan. Texas Law Review, 2009, v. 87, pp. 1545-1593. Disponível em http://papers.ssrn.com/sol3/papers.cfm?abstract_id=1406169 (acesso em 21.11.2010).

LEAL, Aurelino. História Constitucional do Brasil. Brasília: Senado Federal, 2002 (reprodução fac-similar da obra publicada em 1915).

. Theoria e Prática da Constituição Federal Brasileira (primeira parte).

Rio de Janeiro: F. Briguiet e Cia. Editores, 1925.

LEME, Ernesto. Intervenção Federal nos Estados. São Paulo: São Paulo Editora, 1926.

LESSA, Pedro. Do Poder Judiciário. Rio de Janeiro: Liv. Francisco Alves, 1915. 
LEVY, Robert A. MELLOR, William. The Dirty Dozen: how twelve Supreme Court cases radically expanded government and eroded freedom. Washington: Cato Institute, 2008.

LIBERMAN, Jethro K. The Evolving Constitution. New York; Random House, 1992.

LIMONGI FRANÇA, Rubens. Hermenêutica Jurídica. São Paulo: Saraiva, 7a . ed., 1999.

LINARES QUINTANA, Segundo V. Tratado de la Ciencia Del Derecho Constitucional, t. I. Buenos Aires: Editorial Alfa, 1953.

- Tratado de Interpretación Constitucional (tomo I) Buenos Aires:

Abeledo Perrot, $2^{\mathrm{a}}$. ed., 2008.

LOPES, José Reinaldo Lima. O Oráculo de Delfos: o Conselho de Estado no BrasilImpério. São Paulo: Saraiva, 2010.

LORENZETTI, Ricardo Luis. Teoria da Decisão Judicial. São Paulo: ed. Revista dos Tribunais, 2009 [tradução de Teoría de la Decisión Judicial, Rubinzal Culzoni Editores, Argentina, 2008].

MACHADO DE ASSIS. Papéis Avulsos. Rio de Janeiro: Garnier, 1989.

MAIER, Pauline. Ratification - The People Debate the Constitution, 1787-1788. New York: Simon \& Schuster, 2010.

MALTZ, Earl M. Rethinking Constitutional Law: originalism, interventionism and the politics of judicial review. USA: University Press of Kansas, 1994.

MARTINS, Ives Gandra da Silva. BASTOS, Celso. Comentários à Constituição do Brasil. Vol. I. São Paulo: Saraiva, 1988. Vol. II, 1989. Vol. IX, 3ª ed., 2002.

MARTINS, Ives Gandra da Silva. Manipulação de patrimônio genético à luz da Constituição Federal e da MP 2186-16/2001. Revista Justiça \& Cidadania, edição 120, julho 2010, pp. 8-13.

(parecer). Disponível em http://bdjur.stj.gov.br, acessso em 11.10.10.

MAXIMILIANO, Carlos. Hermenêutica e Aplicação do Direito. Rio de Janeiro: Forense, $18^{\mathrm{a}}$. ed., 1999.

Comentários à Constituição Brasileira de 1891. Brasília: Senado Federal, 2005. Reprodução fac-similar da $1^{a}$. edição, Rio de Janeiro, 1918.

MEESE, Edwin (III); SPALDING, Matthew. FORTE, David (orgs.) - The Heritage Guide to the Constitution. Washington: The Heritage Foundation, 2005.

MENDES, Gilmar Ferreira. COELHO, Inocêncio Mártires. BRANCO, Paulo Gustavo Gonet. Curso de Direito Constitucional. São Paulo: Saraiva, 2007. 
MEYER-PFLUG, Samantha. Das especificidades da interpretação constitucional. In: Lições de Direito Constitucional em Homenagem ao Jurista Celso Bastos (orgs.: Ives Gandra da Silva Martins, Gilmar F. Mendes, André Ramos Tavares). São Paulo: Saraiva, 2005 .

MILLER, Bradley W. Beguiled by Metaphors: The "Living Tree" and Originalist Constitutional Interpretation in Canada (Draft). Texto disponível em http://papers.ssrn.com/sol3/papers.cfm?abstract_id=1272042; acesso em 10.01.2010.

MIRANDA, Jorge. Jurisprudência Constitucional Escolhida, vol. I. Lisboa: Universidade Católica Editora, 1996.

MORAES, Alexandre de. Direito Constitucional. São Paulo: Atlas, 18 ${ }^{\mathrm{a}}$. ed., 2005; $24^{\mathrm{a}}$. ed., 2009.

Garantia Suprema da Constituição. São Paulo: Atlas, 2000.

A tendência moderna de imbricação entre o controle difuso e o controle concentrado no âmbito do Supremo Tribunal Federal. Anais da VI Conferência dos Advogados do DF, 2008, pp. 76-84.

MUÑOZ LEÓN, Fernando. La Interpretación Originalista de nuestra Constitución: es Posible y Deseable? Palestra proferida nas XXXVI Jornadas Chilenas de Derecho Público ( http://www.derecho.uchile.cl/jornadasdp/ponencias.htm ). Universidade do Chile, 2005 (acesso em 2.11.2010) .

MUTA, Luis Carlos Hiroki. Direito Constitucional. Tomo I. São Paulo: Elsevier, 2007.

NESTER, Alexandre Wagner. O art. 68 do ADCT e a titulação de terras a remanescentes de comunidades de quilombos. Disponível no sítio: www.justen.com.br, Informativo n. 15, 2008. (acesso em 27.11.2010).

NEVEU, Franck. Dicionário de Ciências da Linguagem. Petrópolis: Vozes, 2007.

NIETZSCHE, Friedrich. Obras Incompletas. Coleção Os Pensadores, vol. XXXII. São Paulo: Abril Cultural, 1 ${ }^{\mathrm{a}}$. ed, 1974.

NOGUEIRA, Octaciano (org.). Doutrina Constitucional Brasileira (Constituição de 1946). Brasília: Senado Federal, 2006.

NOVELINO, Marcelo. Direito Constitucional. São Paulo: Método, 3a. ed., 2009.

NUNES LEAL, Vitor. Coronelismo, Enxada e Voto. 1997.

OCTÁVIO, Rodrigo. VIANNA, Paulo Domingues. Elementos de Direito Público Constitucional. Rio de Janeiro: F. Briguiet e Cia. Editores, 1913.

O'NEILL, Johnathan. Originalism in American Law and Politics: A Constitutional History. Baltimore: The Johns Hopkins University Press, 2005. 
PAIXÃO, Cristiano. BIGLIAZZI, Renato. História constitucional inglesa e americana: do surgimento à estabilização da forma constitucional. Brasília: Editora Universidade de Brasília: Finatec, 2008.

PALUMBO, Arthur E. The Authentic Constitution - An Originalist View of America's Legacy. New York: Algora Publishing, 2009.

PATAPAN, Haig. The Dead Hand of the Founders? Original Intent and the Constitutional Protection of Rights and Freedoms in Australia. Federal Law Review, vol. 25/2, 1997, pp. 211-236 (http://www98.griffith.edu.au/dspace/handle/10072/16203, acesso em 24.10.2010).

PÉREZ ROYO, Javier. Curso de Derecho Constitucional. Madri: Marcial Pons, $11^{\mathrm{a}}$. ed., 2007 (atualizada por Manuel Carrasco Durán).

PILATTI, Adriano. A Constituinte de 1987-1988: Progressistas, Conservadores, Ordem Econômica e Regras do Jogo. Rio de Janeiro: Lumen Juris, 2008.

PIMENTA BUENO, José Antonio. Direito Público Brasileiro e Análise da Constituição do Império. São Paulo, Editora 34, 2002 (título de capa: Marquês de S. Vicente).

PINTO Filho, Francisco Bilac Moreira. A Intervenção Federal e o Federalismo Brasileiro. Rio de Janeiro: Forense, 2002.

PIO XII, PAPA. Encíclica Divino Afflante Spiritu. 1943. Tradução oficial para o português: $\quad$ http://www.vatican.va/holy_father/pius_xii/encyclicals/documents/hf_pxii_enc_30091943_divino-afflante-spiritu_po.html. Acesso em 21.10.2010.

POLETI, Ronaldo. Da Constituição à Constituinte. Rio de Janeiro: Forense, 1986.

PONTES FILHO, Valmir. Curso Fundamental de Direito Constitucional. São Paulo: Dialética, 2001.

PORT, Kenneth L. Article 9 of the Japanese Constitution and the Rule of Law. Cardozo Journal of International \& Comparative Law, n. 13, 2005, pp. 127-160 (disponível em www.heinonline.org, acesso em 11.11.2010).

PORTO, Walter Costa. O Voto no Brasil. Rio de Janeiro: Topbooks, 2ª ed., 2002.

- Dicionário do Voto. Brasília: Editora da Universidade de Brasília. São Paulo: Imprensa Oficial do Estado, 2000.

RAMOS, Elival da Silva. Ativismo Judicial: Parâmetros Dogmáticos. São Paulo: Saraiva, 2010.

evolução. São Paulo: Saraiva, 2010.

Controle de Constitucionalidade no Brasil: perspectivas de Entrevista ao Consultor Jurídico, 1.8.2009.

REALE, Miguel. O Direito como Experiência. São Paulo: Saraiva, 1968. 
Lições Preliminares de Direito. São Paulo: Saraiva, 24a . ed., 1998.

REIS, Palhares Moreira. O partido político e a lei de 1995. In Cármen L. Antunes Rocha e Carlos M. Velloso (orgs.), Direito Eleitoral, 1996, p. 188.

ROCHA, Cármen Lúcia Antunes. República e Federação no Brasil. Belo Horizonte: Del Rey, 1997.

RODRIGUES, Silvio. Direito Civil (Parte Geral). São Paulo: Saraiva, 17a. ed., 1987.

ROSENFIELD, Denis Lerrer. A Captura da Constituição. O Estado de São Paulo, ed. de 10.5.2010. p. A-2.

ROSS, Alf. Sobre el Derecho y la Justicia. Buenos Aires: Eudeba, 1963 (titulo original: On Law and Justice, Londres, 1958; tradução de Genaro Carrió).

ROURE, Agenor de. A Constituinte Republicana (2 vols.). Rio de Janeiro: Imprensa Nacional, 1920.

SÁCHICA, Luis Carlos. Derecho Constitucional General. Santa Fé de Bogotá: Editorial Themis, 1999.

SAGER, Lawrence G. Juez y democracia. Una teoría de la práctica constitucional norteamericana. Madri: Marcial Pons, 2007 [tradução de Justice in Plainclothes. A Theory of American Constitutional Practice. New Haven: Yale University Press].

SAGÜÉS, Néstor Pedro. La Interpretación Judicial de la Constitución. Buenos Aires: Lexis Nexis, $2^{\mathrm{a}}$. ed., 2006.

Astrea, 2009.

Compendio de Derecho Procesal Constitucional. Buenos Aires:

- Derecho Procesal Constitucional: Recurso Extraordinário

(tomo 2). Buenos Aires: Astrea, 4a. ed., 2002.

SATO, Miyuki. Controle de Constitucionalidade: uma sucinta comparação entre o Brasil e o Japão. Revista da Faculdade de Direito da Universidade de São Paulo, vol. 91 (2001).

SATOH, Jun-ichi. Judicial Review in Japan: an overview of the Case Law and an examination of trends in the Japanese Supreme Court's constitutional oversight. Loyola of Los Angeles Law Review, v. 41, 603-629, 2008 (disponível em http://llr.lls.edu/docs/41-2satoh.pdf, acesso em 10.11.2010).

SAVIGNY, Friedrich Carl von. Sistema de Derecho Romano Actual. Tomo I. Madri: F. Góngora y Cia. Editores, 1878.

SCALIA, Antonin. A Matter of Interpretation: Federal Courts and the Law. Princeton University Press, 1997.

SHAFFER, Ralph E. (ed.). The Bork Hearings: highlights from the most controversial judicial confirmation battle in U.S. history. Princeton: Markus Wiener Publishers, 2005. 
SHAMAN, Jeffrey M. The End of Originalism (texto preliminar). Disponível em http://papers.ssrn.com/sol3/papers.cfm?abstract_id=1401562; acesso em 10.01.2010.

SILVA, José Afonso da. Curso de Direito Constitucional Positivo. São Paulo: Saraiva, $6^{a}$. ed., 1990 [tb. consultada a 20 ${ }^{\text {a }}$. ed., Malheiros, 2002].

Comentário Contextual à Constituição. São Paulo: Malheiros,

2005

SILVA NETO, Manoel Jorge e. Curso de Direito Constitucional. Rio de Janeiro: Lumen Juris, 2006 (também consultada a 5. edição, 2009).

SKIDMORE, Thomas. Brasil: de Castello a Tancredo. São Paulo: Paz e Terra, $8^{\text {a }}$. ed., 2004.

SLAIBI FILHO, Nagib. Direito Constitucional. Rio de Janeiro: Forense, 2004.

SOLUM, Lawrence B. Semantic Originalism. [Draft] 2009. Disponível em http://papers.ssrn.com/sol3/papers.cfm?abstract_id=1120244 (acesso em 10.01.2010).

SONTAG, Susan. Contra a Interpretação. Porto Alegre: L\&PM, 1987.

SOUTO, João Carlos. Suprema Corte dos Estados Unidos - Principais Decisões. Rio de Janeiro: Lumen Juris, 2008.

STOCO, Rui. STOCO, Leandro de Oliveira. Legislação Eleitoral Interpretada. São Paulo: Revista dos Tribunais, $3^{\mathrm{a}}$. ed., 2010 (também consultada a $2^{\mathrm{a}}$. edição, 2006).

STORY, Joseph. Commentaries on the Constitution of the United States, 5a. ed., 1891 (original de 1833; edição fac-similar publicada em 2010).

TAKAHASHI, Kazuyuki. Comment. 53 Law \& Contemporary Problems 189, 1990 (texto disponível em www.heinonline.org., acesso em 16.11.2010).

TAVARES, André Ramos. Curso de Direito Constitucional. São Paulo: Saraiva, 5a . ed., 2007; 8 ${ }^{\mathrm{a}}$. ed., 2010.

UMEDA, Sayuri. Japan - Article 9 of the Constitution. Law Library of Congress, 2004. Disponível em http://www.loc.gov./law/help/JapanArticle9.pdf (acesso em 20.10.2010).

VARELA, Alfredo. Direito Constitucional Brasileiro: reforma das instituições nacionais. Ed. fac-similar do original de 1898. Brasília: Senado Federal, 2002.

VIGO, Rodolfo Luís. Interpretação Constitucional. Buenos Aires: Lexis Nexis/Abeledo Perrot, 2a. ed., 2004.

WHITTINGTON, Keith E. Constitutional Interpretation: textual meaning, original intent and judicial review. Lawrence: University Press of Kansas, 1999.

WOLFE, Christopher. How to Read the Constitution: Originalism, Constitutional Interpretation and Judicial Power. Lanham, USA: Rowman \& Littlefield Pub. Inc., 1996. 
WRÓBLEWSKI, Jerzy. Constitución y Teoría General de la Interpretación Jurídica. Madrid: Civitas Ediciones, 2001.

ZAGREBELSKY, Gustavo. Discurso proferido nas comemorações do cinqüentenário da Corte Constitucional italiana (22.04.2006). 